UNIVERSIDADE DE SÃO PAULO

PROGRAMA DE PÓS-GRADUAÇÃO INTERUNIDADES EM ESTÉTICA E HISTÓRIA DA ARTE

JOSEANE ALVES FERREIRA

PERFORMANCES EM MUSEUS DA CIDADE DE SÃO PAULO: PRESERVAÇÃO, DOCUMENTAÇÃO E REGISTRO

ORIENTADORA: PROFA. DRA. JANE A. MARQUES

SÃO PAULO

ABRIL 2018 
AUTORIZO A REPRODUÇÃO E DIVULGAÇÃO TOTAL E PARCIAL DESTE TRABALHO, POR QUALQUER MEIO CONVENCIONAL OU ELETRÔNICO, PARA FINS DE ESTUDO E PESQUISA, DESDE QUE CITADA A FONTE.

Catalogação da Publicação

Biblioteca Lourival Gomes Machado

Museu de Arte Contemporânea da Universidade de São Paulo

Ferreira, Joseane Alves.

Performance em museus da cidade de São Paulo: preservação, documentação e registro / Joseane Alves Ferreira ; orientadora Jane Aparecida Marques. -- São Paulo, 2018.

155 f. : il.

Dissertação (Mestrado - Programa de Pós-Graduação Interunidades em Estética e História da Arte) -- Universidade de São Paulo, 2018.

1. Performance - Brasil. 2. Arte Contemporânea - Brasil. 3. Museus de Arte - Brasil. 4. Documentação Museológica. 5. Mercado de Arte. I. Marques, Jane Aparecida. II. Título. 



\title{
PERFORMANCES EM MUSEUS DA CIDADE DE SÃO PAULO: PRESERVAÇÃO, DOCUMENTAÇÃO E REGISTRO
}

\author{
Dissertação apresentada ao Programa de Pós-Graduação \\ Interunidades em Estética e História da Arte, como requisito \\ parcial para obtenção do título de Mestre em Estética e \\ História da Arte, linha de pesquisa: Produção e circulação da \\ arte.
}

Orientadora: Profa. Dra. Jane Aparecida Marques. 
"O silêncio, a solidão e a ausência de movimento de um Mundo Parado, formam a grande tragédia que conduz ao medo. A passividade pertencia a um mundo parado e é um convite à agressão e ao movimento. A passividade é um estado receptor apropriado ao medo. A ação demonstra uma ausência de medo e é pela ação que o medo é vencido".

(Flávio de Carvalho. A origem Animal de Deus é um estudo teórico. Ed Difusão Europeia, 1973)

Para meu pai Francisco Ferreira e minha irmã Jorli Aves Ferreira (in memoriam) 


\section{AGRADECIMENTOS}

Inicialmente agradeço a minha família, minha mãe Therezinha Alves Ferreira, que tudo me deu, a começar pela vida, e os valores éticos, além do seu amor e carinho incondicional; ao meu irmão Jose Alves Ferreira, que me inspira e me orgulha, um exemplo a seguir de conduta e vitória; a minha cunhada Maria Lucia Lúcia Velloza Ferreira, que é uma irmã, sempre me apoiou e comemorou a cada pequena vitória, por sua enorme generosidade; minhas sobrinhas Carolina Velloza Ferreira e Ligia Velloza Ferreira, que me inspiram e auxiliam em tempo integral, principalmente nessa jornada, elas que já me superaram, gentilmente e reiteradamente me dizem: você nos inspira tia; minha irmã do coração Fátima Aparecida Glasser, e seu filho Luiz Octávio Glasser, meu sobrinho e afilhado, que me ensinaram que família é muito mais do que laços sanguíneos, e meu marido, parceiro Diogo Gomes dos Santos, que além da alma de artista, porque é um cineasta, é pesquisador de culturas populares, uma das personalidades mais relevantes do cineclubismo brasileiro, que o tempo todo esteve ao meu lado.

Desejo agradecer os meus colegas do programa, que dividiram momentos únicos na minha caminhada, em especial: Ana Paula Pismel, que me ajudou em tempo integral; Antonio Herci; Carolina Nery; Cristina Bonfigliori, que me inspiraram e foram modelo de conduta acadêmica; Delmira Nardi, pessoa extremamente generosa e amiga; Edson Oliveira, que desde o primeiro contato me impulsionou a ingressar nesse programa; Rosana Della Piazza, pelos momentos felizes e criativos; Rosane Demeterco Bussmann, amiga que divide comigo a mesma orientadora, que me inspira, me ajuda a continuar, que sempre acreditou no meu potencial.

Aos professores do Programa de Pós-Graduação Interunidades em Estética e História da Arte [PGEHA], que foram referências para minha pesquisa: $\operatorname{Prof}^{\mathrm{a}} \operatorname{Dr}^{\mathrm{a}}$. Elza Maria Ajzenberg, por me convidar e permitir que eu fosse ouvinte e aluna especial, me abrindo caminhos para o meu ingresso no mestrado; Prof. Dr. Edson Leite, que me indicou minha orientadora e participou da minha qualificação; Prof. Dr. Artur Lara, pela experiência performática; Prof. Dr. Artur Matuck, que me ampliou o olhar sobre arte, sobretudo, sobre performance; as $\operatorname{Prof}^{a}$ Dr$^{\mathrm{a}}$. Carmem Sylvia Guimarães Aranha; $\operatorname{Prof}^{\mathrm{a}}$. Dr ${ }^{\mathrm{a}}$. Daisy Valle M. Peccinini; Profa. Dra . Helouise Lima Costa; Prof ${ }^{a} \operatorname{Dr}^{\mathrm{a}}$ Ana Maria Magalhães; e $\operatorname{Prof}^{\mathrm{a}} \operatorname{Dr}^{\mathrm{a}}$ Maria Cristina Freire, que me apresentaram novas experiências e visões de arte.

Não poderia deixar de agradecer as instituições que me receberam e forneceram informações fundamentais, a saber: Centro Universitário Belas Artes de São Paulo; Galeria Vermelho; Museu de Arte Contemporânea [MAC-USP]; Museu de Arte Moderna de São Paulo [MAM-SP]; Museu de Arte de São Paulo [MASP]; Pinacoteca de São Paulo e SESC Pompeia.

Agradecimento muito especial às pessoas que me cederam sua imagem e voz, entrevistas que foram sine qua non, para melhor compreensão e desenvolvimento dessa dissertação: Cauê Alves; Alcimar Frazão: Fernanda Pitta; Juliana Moraes; Laura Lima; Lorival Cuquinha; Marco Gallon; Maurício Ianês e Naira Ciotti.

Finalmente a minha orientadora $\operatorname{Prof}^{\mathrm{a}} \operatorname{Dr}^{\mathrm{a}}$. Jane Aparecida Marques, que não só me orientou, mas iluminou meu caminho, nessa trajetória tão importante da minha vida.

A todos, muito obrigada! 



\section{RESUMO}

Esta dissertação se propõe a investigar a linguagem artística de performances e sua inclusão em acervos e coleções nas instituições de arte da cidade de São Paulo, Brasil, à luz das sutilezas e produções artísticas contemporâneas. O objetivo é identificar as escolhas e procedimentos de aquisições de performances em acervos por meio dos registros, bem como seus desdobramentos haja vista essa linguagem se caracterizar por sua imaterialidade. $\mathrm{O}$ estudo de natureza exploratória está baseado em pesquisas teórica, documental e qualitativa, a partir de entrevistas com especialistas, analisadas com auxílio da técnica de análise de conteúdo. Constata-se que obras imateriais, como a performance, que acontecem em tempo e espaço determinados, estão sendo incluídas nas instituições de arte como criações artísticas. Além disso, o estudo aponta caminhos para o entendimento de que expressões artísticas de cunho imaterial podem ser conservadas, apreciadas e reencenadas, com o status de obras de arte. O estudo apresenta como contribuição o mapeamento de acervos de performances em São Paulo, e distingue os diversos tipos de registros dessa linguagem, facilitando debates referentes à memória e à divulgação dessa prática artística.

Palavras chave: Performance; Acervo; Registro; Arte contemporânea; Instituições de arte. 


\begin{abstract}
This thesis proposes to investigate the artistic language of performances and their inclusion in the collections of art institutions in São Paulo, Brazil, through the light of the subtleties and contemporary artistic productions. The objective is to identify the choices and procedures about the acquisitions of performances in collections through the records, as well as their unfolding, since this artistic language is characterized by its immateriality. The exploratory study is based on theoretical, documentary and qualitative research, based on interviews with specialists, analyzed with the help of the content analysis technique. It can be seen that immaterial works, such as performance, that take place in determined time and space, are being included in art institutions as artistic creations. In addition, the study points out ways for understanding that immaterial artistic expressions can be conserved, appreciated and reenacted, with the status of works of art. The study presents a contribution to map collections of performances in São Paulo, and distinguishes the different types of records of this language, facilitating debates regarding the memory and the dissemination of this artistic practice.
\end{abstract}

Keywords: Performance; Collection; Record; Contemporary art; Institutions of art. 


\section{LISTA DE FIGURAS}

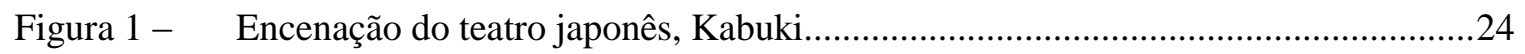

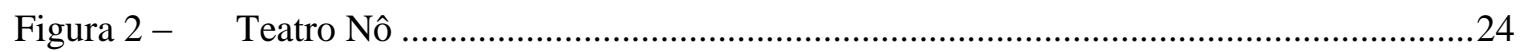

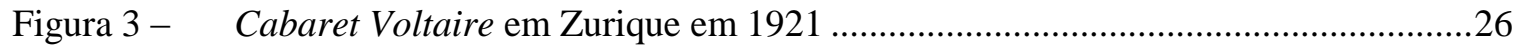

Figura 4 - Grupo Gutai: Saburo Murakami - Atsuko Tamaka - Kazuo Shiraga, $1956 / 1960$

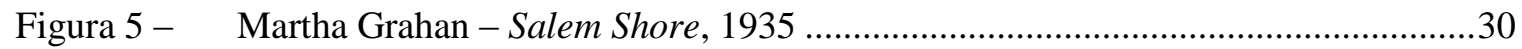

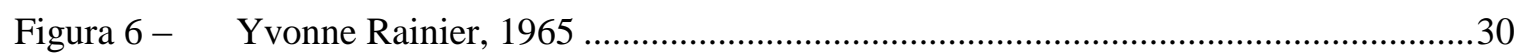

Figura 7 - Jackson Pollock - Action painting ………............................................................ 31

Figura 8 - Yves Klein - Orquestra ao fundo toca Sinfonia Monotônica, de uma nota só........31

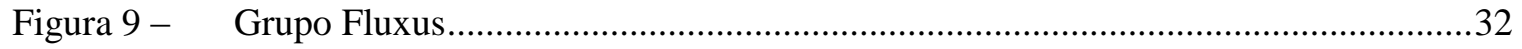

Figura 10 - Flavio de Carvalho, New Look, passeata por São Paulo, 1956................................33

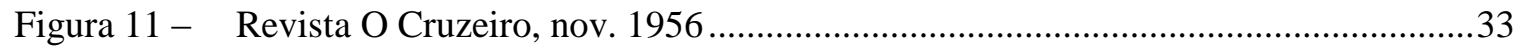

Figura 12 - 18 Happenings em 6 Partes, de Allan Kaprow, 1959 …........................................40

Figura 13 - Como explicar quadros a uma lebre morta - Performance de Joseph Beuys, na Galerie Schmela, Düsseldorf, 26 novembro 1965

Figura 14 - Performance Esculturas Vivas, de Piero Manzoni, 1961. Mostra o Corpo expandido.....

Figura 15 - Diagrama para "Dança de Gestos", 1926Ao lado cena de Dança de Gestos, com Schlemmer, Siedhoff e Kaminsky.... 52

Figura 16 - “O Nome”, Projeto Octógono, Pinacoteca do Estado, São Paulo (2013).................56

Figura 17 - Maurício Ianês, "Refus" ("Recusa"), Centro Nacional de Artes Plásticas da

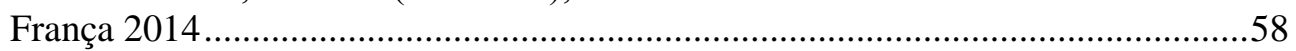

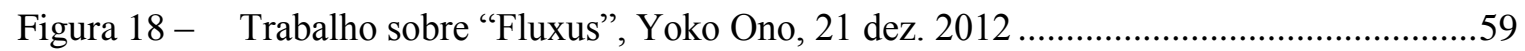

Figura 19 - Lourival Cuquinha, "Parangolé”, 2002-2007 Reprodução ou original do "Parangolé", de Hélio Oiticica, pendurado dentro de uma cerca elétrica (9V).......60

Figura 20 - "Quadris de Homem= Carne/Mulher=Carne", Laura Lima, 1995 ..........................62

Figura $21-$ Bala de Homem $=$ Carne/Mulher $=$ Carne, Laura Lima, 1997...............................62

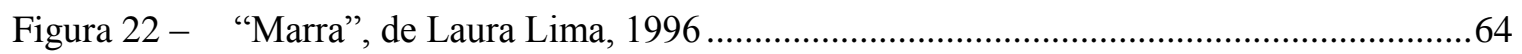

Figura 23 - Registro/instruções de ações de Paulo Bruscky, em exposição individual na Galeria Nara Roesler, 2 de agosto 2017

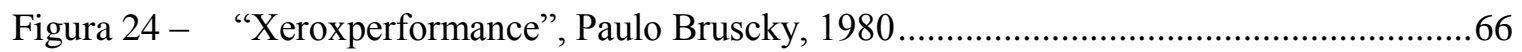

Figura 25 - “True Rouge”, Tunga, 1997 (redes, madeira, vidro soprado, pérolas de vidro, tinta vermelha, esponjas do mar, bolas de sinuca, escovas limpa-garrafa, feltro,

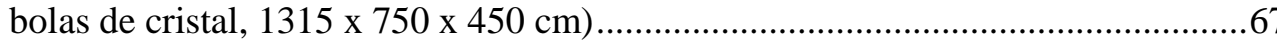

Figura 26 - “A Escritura”, de Maurício Ianês, SP-Arte, 2017 ......................................................69

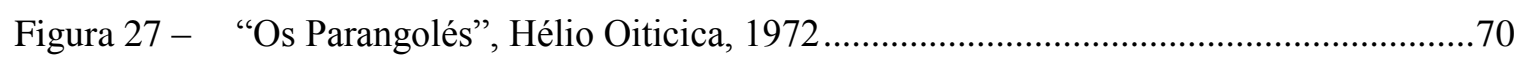

Figura 28 - Performance "Parangole" de Lorival Cuquinha ........................................................ 70

Figura 29 - "Palhaço com buzina reta - monte de irônicos", de Laura Lima, 2007 ....................72 
Figura 30 - "Experiência no 3", ou "New Look" - Traje do "Novo Homem dos Trópicos", Flávio de Carvalho (1956)......................................................................................

Figura 31 - Performance Intervensão Movimento de Arte Pornô, de Eduardo Kac (1982).......75

Figura 32 - Exposição Terra Comunal. "The house with the ocean view” ("A casa com vista para o mar"), Marina Abramović, 2002 ……………………………...........76

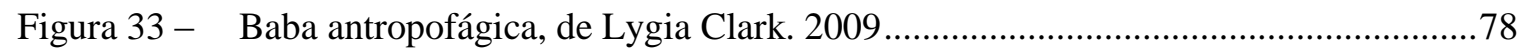

Figura 34 - Performance "Como depender da boa vontade de estranhos", de Maurício Ianês,

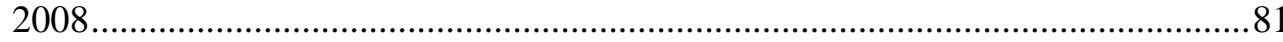

Figura 35 - "Exposição Monumentos Temporários", Fyodor Pavlov-Andreevich, MAC-SP, 2017 (espaço de exibição de vídeos)

Figura 36 - "Exposição Monumentos Temporários", Fyodor Pavlov-Andreevich, MAC-SP, 2017.

Figura 37 - "Shoot”, Chris Burden, 1971 F Space, Santa Ana, Califórnia .................................85

Figura 38 - "Divisor”, Lygia Pape, 1968, no Museo Reina Sofía, em2011 .................................86

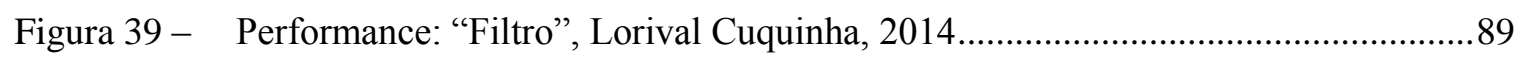

Figura 40 - Performance "Zona morta”, Mauríco Ianês, Galeria Vermelho, São Paulo,

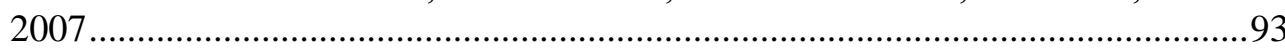

Figura 41 - Performance "DNA de DAN", Maikon K, na exposição "Terra Comunal",

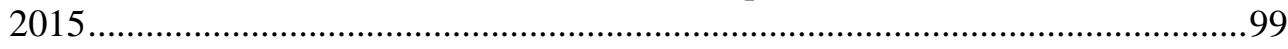

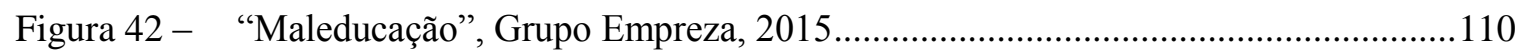

Figura 43 - “Tríptico Matera”, Performance corpo política, Grupo Empreza, 2013 ................110

Figura 44 - Mapa com as instituições pesquisas e/ou visitadas por darem acesso a performances, 2016-2018 


\section{SUMÁRIO}

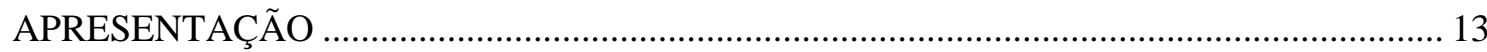

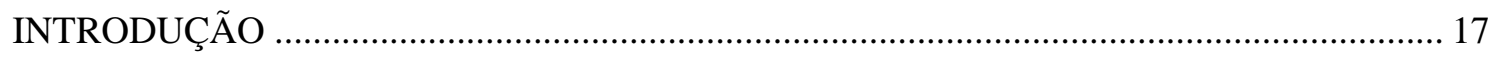

CAPÍTULO I - PERFORMANCE, UM PERCURSO, UMA LINGUAGEM ARTÍSTICA ..... 23

1.1 ORIGEM E VANGUARDAS: MAPEAMENTO.................................................... 23

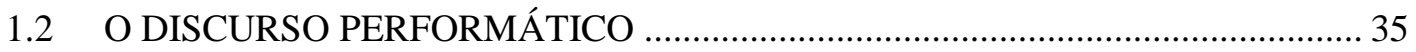

1.3 CONSIDERAÇÕES DA LINGUAGEM PERFORMANCE: A VISÃO DA ARTE CONTEMPORÂNEA ............................................................................. 45

CAPÍTULO II - REGISTROS DE PERFORMANCE ……....................................................... 50

2.1 DOCUMENTOS E CERTIFICADOS DE PERFORMANCES ................................. 50

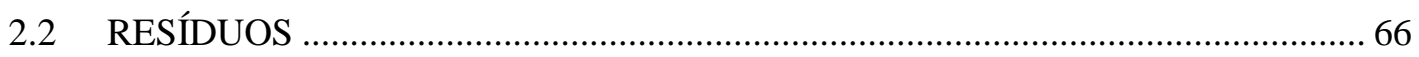

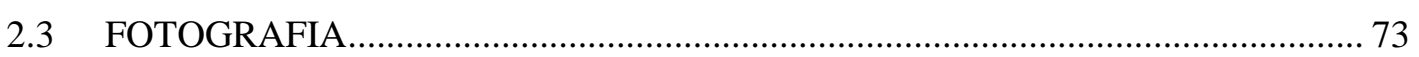

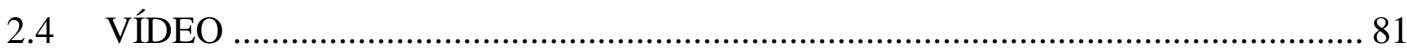

CAPÍTULO III - ACERVOS E COLEÇÕES DE PERFORMANCE NO SÉCULO XX........... 92

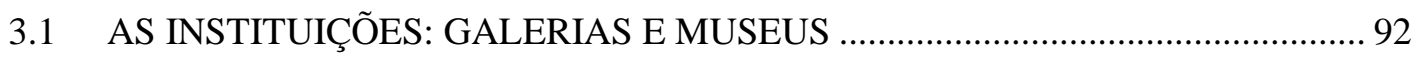

3.2 O MERCADO DAS ARTES E A PERFORMANCE .......................................... 101

3.3 COLECIONAR PERFORMANCES: UM NOVO PARADIGMA NO

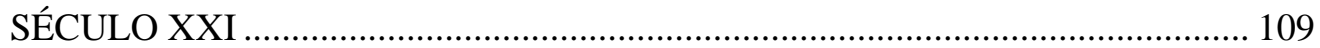

CAPÍTULO IV - INVENTÁRIO DE ACERVOS DE PERFORMANCE EM

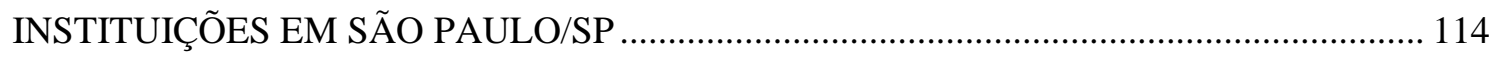

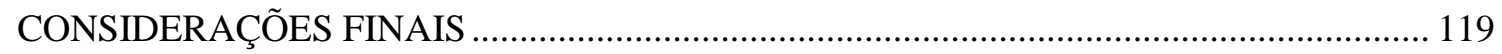

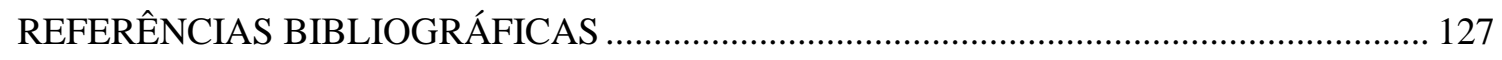

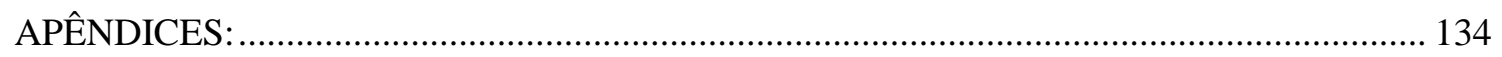

APÊNDICE A - ENTREVISTADOS (breve currículo) …………................................... 135

APÊNDICE B - ROTEIRO DAS ENTREVISTAS ........................................................... 144

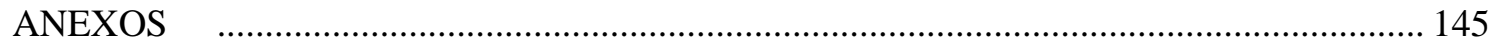

ANEXO I - PERFORMANCE “O NOME”, DE MAURÍCIO IANÊS, PROJETO OCTÓGONO, PINACOTECA DO ESTADO, SÃO PAULO (2013) ..................... 146

ANEXO II - DESCRIÇÃO PERFORMANCE “PARANGOLÉ”, DE LOURIVAL CUQUINHA...

ANEXO III - RECRUTAMENTO DE ARTISTA PARA EXECUTAR OBRA DE LAURA LIMA

ANEXO IV - COLEÇÃO MAC-USP - REGISTROS DE AÇÃO, DE PERFORMANCE E DE INSTALAÇÃO 


\section{APRESENTAÇÃO}

O estudo da expressão artística denominada performance, sua relação com outras linguagens e movimentos, seu processo de criação, e sua repercussão no Brasil, são aspectos abordados por vários autores, como por Renato Cohen (2013). Pesquisador e performer, Cohen analisa obras e artistas renomados, que se utilizaram da performance para se expressarem, ao longo dessa trajetória tanto as obras como os artistas estiveram ligados ideologicamente à não-arte Cohen (2013) discorre sobre os manifestos, apresentações que sugerem as origens e o status dos quais a performance dispôs nos séculos XX e XXI. Ainda, esse mesmo autor ratifica a importância da arte no século XX e XXI, ressaltando seu poder de transformar, sobretudo por intermédio de (re)transformações ou releituras devido seu acaráter multidisciplinar, e estar ligada ao seu tempo. O autor dá indicativos sobre o porquê dessa linguagem também estar presente em coleções e acervos (COHEN, 2013).

A performance, por ter caráter híbrido ou de fronteira, envolvendo outras áreas de conhecimento e diversas linguagens artísticas, pode ter suas origens em vários movimentos artísticos, como as vanguardas: futurismo, dadaísmo, a Bauhaus, ou manifestações mais tradicionais como o Kabuki. O termo "performance" por exemplo pode ser entendido como desdobramento de outras manifestações artísticas, que propõe várias leituras e pesquisas. Nesse sentido, Jorge Glusberg (2013), em “A arte da performance", propõe diversas reflexões sobre essa linguagem e sua história, ao lado de artistas que desenvolveram trabalhos que, de alguma forma, foram alicerçando o que se concebe por performance. A abordagem de Glusberg (2013) também é fonte para entendimento e ampliação da intervenção da linguagem com o público, devido as suas origens, que fornecem elementos para a compreensão dessa expressão artística, e podem apontar elementos para a incorporação desses trabalhos em acervos e coleções.

Entender, analisar as origens, artistas e trabalhos de performance parecem condições sine qua non, ou mesmo pré-requisito, para a compreensão de acervos e coleções de performances, afinal, a guarda e conservação de obras de arte passam pelo crivo de críticos e pesquisadores quanto de sua fruição. Nesse contexto, Richard Schechner (2006) discorre sobre o surgimento da performance, apresenta conceitos do termo utilizados em outros segmentos, desde uma visita ao filósofo Heráclito a várias ações artísticas, no sentido de ampliar o universo da performance e seu entendimento. Aspectos sociais, rituais, comportamentais, linguagens corporais, interatividade, novas 
mídias, a vida cotidiana, além de outras questões como: onde e como acontecem as performances? Toda essa abordagem oferece elementos para aprofundar a análise desta pesquisa, sobretudo sobre o entendimento desse segmento artístico (SCHECHNER, 2006).

Uma abordagem muita rica é apresentada por Roselee Goldberg (2015), que estuda as questões políticas, sociais e tecnológicas, que marcaram a história dessa linguagem no contexto histórico, desde as vanguardas do século XX até o início do século XXI, apontando como os museus absorveram a performance como expressão fundamental de diálogo com o público. Além disso, Goldberg (2015) apresenta vários artistas e suas obras, por meio de imagens e descrições, e à medida que vai explicitando a intimidade dos artistas, e seus períodos históricos, aborda como cada um deles fez uso da arte como forma de expressão e de resposta ao mundo. Além disso, discorre sobre como essa arte de apresentação ao vivo pode chegar a outras gerações por meio de pesquisas e registros que hoje estão presentes em museus.

Não menos importante é a compreensão da trajetória da arte e seus desdobramentos, principalmente no século XX, período em que a performance apresenta sinais efetivos de sua presença no universo das artes. Durante muitos séculos a arte esteve ligada ao naturalismo, representando basicamente a natureza, principalmente em quadros e esculturas. Porém, em meados do século XIX, rupturas apontavam para o advento da descoberta da eletricidade e o aparecimento da fotografia, expressão artística ligada diretamente à máquina, e não mais a habilidade e destreza do artesão, que executava o trabalho (ARGAN, 1993). A arte, as novas tecnologias e a conexão com novos materiais utilizados no universo das artes, abriram espaços para outras linguagens desabrocharem, devido às novas formas de se ver o mundo. Anne Cauquelin (2005), por exemplo, trata a arte contemporânea, seus aspectos, questões de consumo, demanda, crítica de arte, da produção artística e do complexo universo que envolve a arte, o artista, o público, as instituições e as modificações da estrutura econômica da sociedade. Cauquelin (2005) trata de alguns questionamentos que emergem, como: Quem é o produtor de arte? Ou quem a comercializa ou a coleciona? Quem define o que é ou não é arte contemporânea? $\mathrm{E}$, finalmente, quem a consome? Questões como o funcionamento do sistema de arte ou como o artista necessita se projetar, expor e renovar são questões apontadas como consequência do próprio sistema.

Outro aspecto importante apresentado por Cauquelin (2005) é a ruptura na arte moderna e contemporânea introduzida por Duchamp e seus ready-mades, fortalecendo o poder da instituição de arte: "Expor um objeto é intitulá-lo" (CAUQUELIN, 2005, p. 
101). Nesse contexto, a performance pode ser inserida como expressão imbricada de ideologias, apesar de ter caráter imaterial. A autora proporciona ampliação do entendimento de arte e artistas com a vida cotidiana, no sentido de conseguir seu espaço nesse sistema contemporâneo de arte, assim como as demais linguagens, inclusive a performance, o que aponta caminhos para essa expressão adentrar em coleções e acervos em uma tentativa de garantir o status de arte.

No universo contemporâneo do sistema de arte, a arte como objeto ou mercadoria foi abordada por Ferreira Gullar (1993), pensador e crítico de arte, em ensaio sobre o processo de consolidação do capitalismo e da massificação da cultura que facilitou a qualificação de uma obra artística pela própria necessidade do capitalismo em tornar tudo consumível e descartável. Segundo esse autor, novas formas de "arte" surgiram para gerar interesse ao consumo e movimentar a economia. O debate sobre o fim da essência da arte, pelas imposições do sistema capitalista e o comportamento da sociedade em relação à arte têm se modificado em razão do grande avanço tecnológico pela busca do novo. A hipótese de que o entendimento de "arte descartável" tem por propósito a popularidade, a repercussão pela mídia, a fama, glorificando o êxito exterior. Nesse sentido, renasce a necessidade de repensar a arte como uma invenção humana, que enriquece a sociedade, devendo esta ser livre e desimpedida.

Outra indagação importante foi apresentada por Gullar (1993, p. 41): “o novo é efêmero, mesmo porque seria uma contradição, em termos, imaginara-se um novo permanente". No passado, os artistas tomavam como base os modelos clássicos dos grandes mestres, isso era comum, contudo esses artistas imprimiam sua visão particular nas obras, sem desejar apresentar ineditismo. Contudo, em uma sociedade capitalista, inovar tornou-se uma necessidade.

Mais do que constatar lacunas na trajetória da arte contemporânea e seus desdobramentos, é importante traçar passos para o entendimento de conceitos de arte desde meados do século XX até o século XXI, no sentido de apreender a arte como expressão essencial da sociedade em todas as suas linguagens (GULLAR, 1993). Essa compreensão é essencial quando se trata de incorporar performances dentro de acervos, em instituições de arte, que são objeto deste estudo.

$\mathrm{Na}$ minha experiência pessoal, como bailarina durante muitos anos, sempre desejei manter a memória e o registro das minhas atuações. Evidentemente programas, anotações e fotos foram os elementos que guardei de minha trajetória, mas com o advento do vídeo, e a facilidade de capturar o movimento, acreditei que esses registros eram suficientes para garantir minha história. Contudo, ao rever esses meus registros, muitas 
inquietações se apresentaram e a intenção dessa dissertação se iniciou, visando melhor entendê-las. 


\section{INTRODUÇÃO}

A performance pertence ao universo das artes contemporâneas e pode ser considerada um dos ícones de arte do século XX. Não é nada fácil defini-la, e é preciso mencionar que ela enfrenta polêmicas relativas ao seu pertencimento em acervos como obra tombada, por integrar as coleções nas instituições públicas, em museus; bem como sobre debater essa linguagem, como suporte de expressão artística. Outro aspecto é sua articulação no mercado de arte, principalmente pelo seu caráter imaterial, em contrapartida com sua pertinência cênica.

Provavelmente, o maior dilema em incluir performance nos acervos e coleções está no fato de que ela não é um bem material, ou um objeto a ser colecionado e conservado, frequentemente sendo preservada apenas por um registro. $\mathrm{O}$ registro tem sido a forma mais presente de arquivamento de performances nos acervos, consagrando essa expressão, no sentido de perpetuar e garantir a história dessa linguagem em seu período, além de assegurar essas práticas nas páginas da história.

São diversos os registros que a performance vem utilizando, dentre os quais é comum encontrar documentos descritivos das obras, resíduos, fotos e filmes, porém, é relevante salientar que a fotografia e o cinema também são linguagens artísticas. $\mathrm{O}$ vídeo e o cinema, por exemplo, são ferramentas que podem registrar e perpetuar essas experiências e encenações, pela característica da verossimilhança, no entanto, outra questão se coloca: essas linguagens como arte têm sua própria gramática.

Os acervos e/ou coleções de performances são manifestações artísticas que representam o mundo sob uma nova perspectiva que visa entender a arte. Como normalmente ela acontece no ato de sua apresentação, sua adoção por instituições tem sido dificultada por instituições de estrutura tradicional de colecionar objetos de arte.

Para que tal compreensão seja possível, este estudo se propõe a investigar o conceito e desdobramentos de performance como uma tendência da arte contemporânea. Além disso, pretende-se analisar questões relativas ao registro dessa prática artística que se consagrou como linguagem no século $\mathrm{XX}$ e se sedimentou no universo das artes contemporâneas, mantendo uma trajetória de fronteira com outras linguagens (FRAZÃO, 2016).

Feiras de artes, galerias e instituições públicas têm performances incluídas em seus acervos e coleções, ampliando o olhar sobre essa linguagem contemporânea de arte, de aspectos singulares de conservação e preservação. Levando-se em conta as 
particularidades da expressão humana dos séculos XX e XXI é preciso garantir a memória de performances nas páginas da história.

No Brasil, mais especificamente no município de São Paulo, o interesse por essa linguagem e a inclusão em algumas instituições vem crescendo, bem como o interesse dos curadores. Em paralelo, debates estão acontecendo, principalmente a respeito de formatos, modelos de registros, questões que estão nas mesas de discussões, tanto pelos artistas, quanto pelas instituições e colecionadores de arte. Pretende-se, assim, indicar os tipos de registros que compõem as coleções e acervos, como peças relevantes da arte no contexto atual.

Essa expressão artística não possui uma matriz como a gravura, que pode ter uma tiragem, uma reprodução. Assim, o objetivo é questionar a possibilidade de perpetuar, registrar e garantir a história desse trabalho, e do período histórico das coleções e acervos. E o que vem se apresentando são registros, em papel, como certificados de compra e venda; memoriais descritivos da obra, para sua encenação ou reperformance; resíduos ou o que restou da apresentação, tratados como objetos, ou até mesmo instalações; fotografias que capturaram o momento e vídeos que registraram a ação ou movimentos. Em alguns casos, a oralidade, elaborada entre artista e instituição, pode ser o caminho para a construção de acervos, ou até mesmo o conjunto dessas propostas de registros sejam elementos do acervo e/ou coleção.

O importante é identificar como acontece a inserção dessa linguagem nos museus de arte em São Paulo: Museu da Arte Moderna de São Paulo [MAM-SP]; Pinacoteca de São Paulo; Museu da Arte Contemporânea [MAC] e Museu da Arte de São Paulo [MASP], levando-se em conta o caráter imaterial da performance, as diversas formas de registros, que compõem as coleções e acervos.

Considerando o universo das artes contemporâneas, a imaterialidade da performance, e o universo de mercado de arte vigente, esse estudo visa responder ao problema de pesquisa: Como acontece a inclusão dessa linguagem artística nos acervos e coleções dos Museus de São Paulo? Como os registros de performances são tratados para essa inclusão?

Assim, tem-se como objetivo geral para a realização desta dissertação: identificar as escolhas e procedimentos de aquisições de performances, nos acervos de museus na cidade de São Paulo, por meio dos registros, já que essa linguagem se caracteriza por sua imaterialidade.

Para responder a esse objetivo geral, elencam-se os seguintes objetivos específicos: 
- entender o que é performance a partir das chamadas neovanguardas (desde os anos 1960) e de seu estabelecimento como gênero artístico, que congrega várias linguagens, associadas ao seu tempo para construir sua própria narrativa;

- identificar e analisar tendências da arte contemporânea, traçando linhas de aproximação entre performance, seu registro e os museus de arte, a lógica do mercado de arte, e os significados dessa linguagem enquanto obra de arte e seus desdobramentos;

- investigar como artistas e especialistas em performance compreendem essa linguagem e como ela integra acervos nos museus de São Paulo;

- analisar e entender os desafios de como preservar a produção de performance em coleções e acervos.

Para atender a esses objetivos, este estudo de natureza exploratória está estruturado em duas vertentes inter-relacionadas: pesquisa teórica e documental (SELLTIZ et al., 1975) que pautou os conceitos abordados, tendo como prioridade o estudo histórico e estético sobre performance.

Em um segundo momento adota-se de pesquisa qualitativa, para a qual foram consultadas fontes primárias, a partir da técnica de entrevistas com profundidade, com base em um roteiro semiestruturado aplicado com especialistas (SELLTIZ et al., 1975): artistas, galeristas, professores de performance em universidades e curadores de instituições de arte.

$\mathrm{O}$ roteiro semiestruturado, com perguntas abertas e fechadas, foi elaborado em consonância com o aporte teórico e com os documentos obtidos, as fontes secundárias. Esse roteiro aborda a compreensão de "performance", suas origens, seus desdobramentos no século XX e XXI (COHEN, 2013; GLUSBERG, 2013; SCHECHNER, 2006), seus meios de registros, sua inclusão em acervos e a importância dessa linguagem nas coleções, visando captar a percepção de especialistas, que propiciam reflexão e análise mais aprofundada sobre o tema e os respondentes discorrerem livremente sobre o tema (vide Apêndice B).

A amostragem adotada foi não probabilística por conveniência, conforme esclarecem Selltiz e colaboradores (1975). A seleção dos entrevistados levou em consideração as distintas perspectivas dessa linguagem, o que possibilitou fazer uma triangulação com os dados teóricos e permitiu aprofundar a análise, já que os acervos normalmente são construídos em diálogo com a curadoria, com os representantes comerciais e com o artista. Outro elemento significativo neste contexto é a Academia, 
que vem incluindo essa linguagem em seus currículos, compreendendo que performance é uma linguagem artística contemporânea.

Dessa forma, a amostra final totalizou 9 (nove) entrevistas, com autorização de imagem e som ${ }^{1}$, segundo os padrões do Sindicato dos Artistas e Técnicos do Estado de São Paulo e do Sindicato dos Trabalhadores da Indústria Cinematográfica do Estado de São Paulo. Todas as entrevistas ${ }^{2}$ foram realizadas entre 4 de maio de 2016 a 17 de setembro de 2017 e organizam-se da seguinte forma:

- 3 artistas (performers), Laura Lima; Lorival Cuquinha e Maurício Ianês, que já tiveram performances como obras tombadas nos acervos de museus em São Paulo;

- 3 especialistas (professores de performance e/ou coordenadores na área em universidades), Cauê Alves, coordenador do Departamento de Artes Visuais do Centro Universitário Belas Artes de São Paulo; Juliana Moraes, professora de performance no Centro Universitário Belas Artes de São Paulo, bailarina e performer e Naira Ciotti, professora adjunta da Universidade Federal do Rio Grande do Norte, Departamento de Artes, integrante do Programa de Pós-Graduação em Artes Cênicas e performer, devido à amplitude de conhecimento desses profissionais;

- 3 representantes de instituições de arte: museus e galerias, que comercializam performances para colecionadores ou para acervos dessas instituições, Alcimar Frazão, coordenador de Artes Visuais do SESC Pompeia; Fernanda Pitta, curadora da Pinacoteca de São Paulo e Marcos Gallon, diretor da Mostra Verbo ${ }^{3}$ de Performance, da Galeria Vermelho.

Todas as entrevistas foram presenciais e gravadas em vídeo. Estima-se que cada uma teve, em média, 40 minutos de duração. Após transcritas foi utilizada a técnica de análise de conteúdo (BARDIN, 2011). De acordo com Bardin (2011), foram consideradas as seguintes etapas:

\footnotetext{
1 Autorizações de imagem e som estão no acervo pessoal da pesquisadora, porque cada uma dessas constitui documento único, assinado por cada entrevistado, constituindo e preservando o direito de propriedade e patrimônio da autora.

${ }^{2} \mathrm{O}$ Apêndice A apresenta um mini currículo e uma foto de cada um dos entrevistados.

${ }^{3}$ A criação da Mostra Verbo, em 2005, foi uma iniciativa da Galeria Vermelho por uma necessidade "dos nossos artistas terem essa plataforma de ação que não tivesse ligada simplesmente a uma data de abertura, ou uma abertura de uma exposição, onde eles pudessem ter a galeria branca e vazia de objetos, onde as pessoas viessem para ver performance (...). Na época era uma Mostra e as edições em 2005 e 2006 foram feitas a partir de convites diretos ao um número ' $x$ ' de artistas, e a partir de 2007 a gente começou a abrir uma coisa parecida com edital para receber projetos não só dos nossos artistas, ou vamos dizer do nosso círculo, mas de outros artistas que quisessem enviar seus projetos. O retorno foi absurdo, na primeira edição 2007 a gente recebeu mais 350 projetos e foi totalmente inesperado para a gente, (...) virou uma coisa que já está meio marcado no calendário da cidade (GALLON, 2016, p. 2).
} 
1- Trabalho de seleção do material a ser utilizado na dissertação: bibliografia referente ao tema, documentos e entrevistas, que deverão ser organizados e sistematizados;

2- Preparação dos materiais: referências bibliográficas (livros, artigos, dentre outras publicações acadêmicas), documentos e fichas para edição dos textos e entrevistas gravadas em vídeo e transcritas para posterior tratamento dos dados;

3- Classificação dos elementos de informação dos documentos: organização e/ou agrupamentos, a partir de critérios comuns, por meio de resumos, palavras-chaves, associação, equivalência e exclusão, explorando ligações entre diferentes variáveis, levando-se em consideração a credibilidade dos entrevistados e dos autores pesquisados;

4- Análise dos resultados: em função de cada entrevista e das pesquisas teórica e documental, confrontando o contexto e tema abordado, para fundamentar a interpretação final.

Para abordar esses aspectos, esta dissertação está estruturada em quatro capítulos, além desta Introdução e da Apresentação. O capítulo I aborda a origem das performances e suas conceituações até seu reconhecimento como linguagem artística. Nesse sentido, abordam-se como se constitui o discurso performático e as considerações dessa linguagem, na perspectiva da arte contemporânea, algumas características e qualidades, os movimentos vanguardistas que apresentaram propostas estéticas e conceituais congruentes à essa linguagem artística e a percepção de artistas, especialistas dessa expressão.

Para aprofundar o tema, no capítulo II se apresentam os registros de performance utilizados pelos artistas, pesquisadores e instituições de arte, tanto a documentação, quanto a(s) peça(s) que pode(m) ser tratada(s) como obra, a saber: documentos, certificados, resíduos ou vestígios, fotografias e vídeos.

O capítulo III aborda o papel da performance no mercado de arte, considerando o contexto das instituições de arte, tais como galerias e museus, bem como suas coleções e acervos.

Por fim, o capítulo IV apresenta um inventário de acervos de performances em instituições de arte em São Paulo, seguido das considerações finais, referências utilizadas na dissertação, apêndices (A - breve currículo dos entrevistados; e B - roteiro utilizado para as entrevistas) e anexos (materiais coletados ao longo da pesquisa sobre performances). 


\section{CAPÍtUlo I - PERFORMANCE, UM PERCURSO, UMA LINGUAGEM ARTÍSTICA}

\subsection{ORIGEM E VANGUARDAS: MAPEAMENTO}

O estudo da expressão artística denominada performance, sua relação com outras linguagens e movimentos, e o processo de criação ao longo da sua trajetória estiveram ideologicamente ligados à não-arte ou ao fim da arte, até então convencionada pelo suporte do objeto artístico. Esse conceito está relacionado com o fim do objeto ou quadro, considerando que cada obra é retratada com uma nova linguagem. No universo ocidental foi apresentado o objeto artístico que "surge de três vertentes: o papier collé $e^{4}$ cubista, o

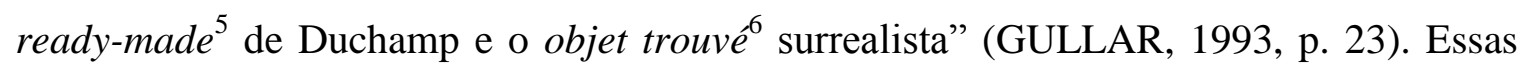
vertentes, primeiramente, introduzem na obra diversos papéis, jornais, selos, que são colados; segundo, substituem o ofício do artista por objetos industrializados e, por fim, os objetos apresentados não estão no contexto natural, mas transpostos criam fantasias.

Isso ocorreu principalmente com manifestos vanguardistas, indicando as origens dessa expressão, em simetria com a importância da arte no nosso tempo, seu poder de transformar, sobretudo as retransformações ou releituras, e a linguagem fragmentada, que dizem respeito ao nosso tempo (COHEN, 2013).

Nesse sentido, a expressão artística não surge do nada, vem repleta de histórias, metáforas, influências e referências. A performance como um recorte no universo da arte também vem carregada de significados ao longo da história do homem e das artes. Em um passado um pouco mais distante se notam indícios dessa linguagem no Oriente com o

\footnotetext{
4 "Picasso, em 1911, cola, em uma natureza morta, um selo de correio, de verdade, sobre a reprodução de um envelope de carta, ele está firmando que nem tudo o que se põe num quadro precisa ser "pintado" pelo pintor. Assim, Braque no ano seguinte usará papel de parede imitando madeira para figurar mesas, guitarras. O passo seguinte e inevitável é eles usarem o papel colado não mais como imitação dos objetos, mas já como textura independente da alusão figurativa" (GULLAR, 1993, p. 23).

${ }^{5}$ Ready-made, de Duchamp, deriva da negação das técnicas como operações programadas com um fim determinado e a substitui por um objeto qualquer que é apresentado como obra de arte. O artista expõe um mictório e assinou como obra, e com esse ato o objeto recebe valor artístico, pois o retira do ambiente natural, com seu valor prático e o recoloca em local, onde os objetos não são utilitários, mas estéticos, ratificando a ideia de valor estético, puro ato mental ou atitude em relação à realidade (ARGAN, 2013).

${ }^{6}$ Objets trouvés (do francês, "objeto encontrado"), ou seja, objeto encontrado ao acaso pelo artista e exposto como obra de arte. "Os surrealistas afirmavam que criador não é apenas quem faz; quem acha também o é. Assim uma pedra encontrada no mato pode ser uma obra de arte... Todos são artistas e ninguém é artista" (GULLAR, 1993, p. 18).
} 
teatro Kabuki ${ }^{7}$ e o $\mathrm{No}^{8}$, ambos de origem japonesa (vide figuras 1 e 2, respectivamente), sem deixar de lembrar os rituais tribais, os mistérios medievais e até mesmo os espetáculos do século $\mathrm{XV}$, assim como os espetáculos de variedades, e as atividades circenses. Essas são manifestações artísticas nas quais o corpo do artista, a ação e a relação direta com o público não são novidades e apontam alguns pontos de congruência com a performance, mas afloram como expressão na arte independente nos anos sessenta.

Figura 1 - Encenação do teatro japonês, Kabuki

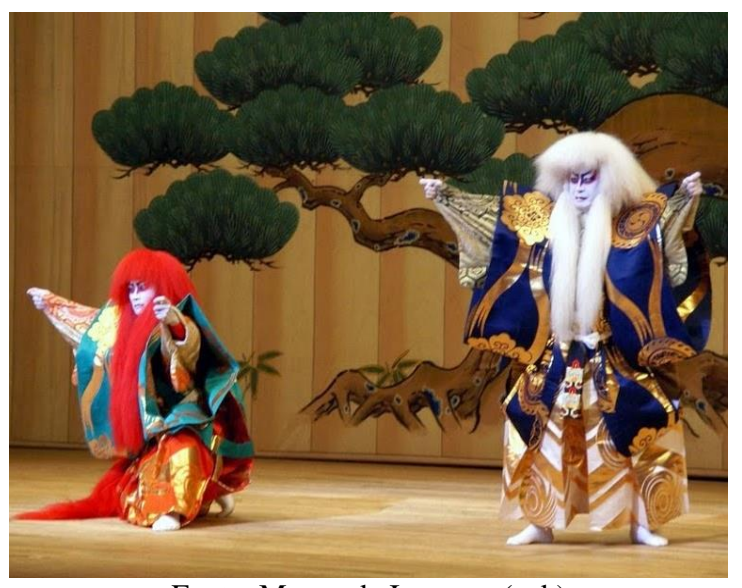

Fonte: Museu de Imagens (s.d.)

http://www.museudeimagens.com.br/kabuki-teatrojapones/
Figura 2 - Teatro Nô

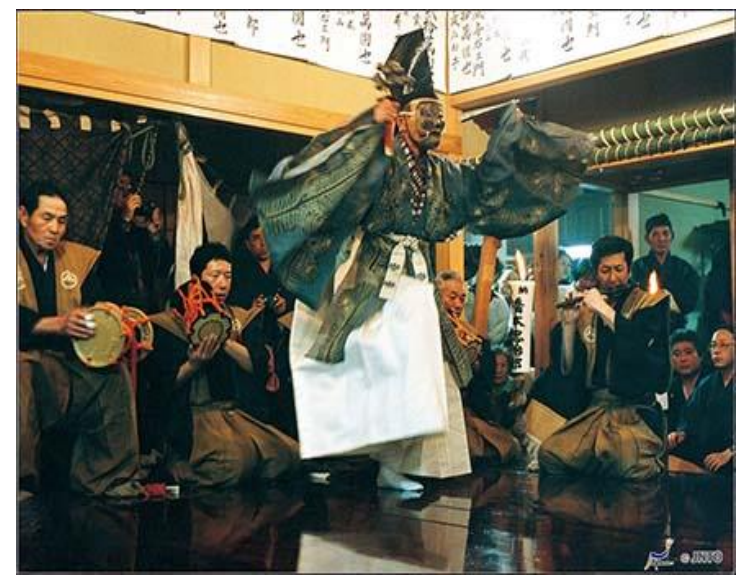

Fonte: Kimura (2015)

https://madeinjapan.com.br/2015/05/20/o-teatro-noh/

Uma característica marcante nessas expressões teatrais era a ironia, o espírito lúdico, em um período em que se buscava diminuir a distância entre arte e vida, em contrapartida com o isolamento da arte denunciada por vários artistas. Outro fator importante foi a absorção de outras linguagens: dança, teatro, música, fotografia e mesmo o cinema, indicando que as novas mídias eram possibilidades do fazer artístico, por meio de máquinas, ampliando o leque de técnicas e plataformas das quais essa linguagem poderia fazer uso (GLUSBERG, 2016).

\footnotetext{
${ }^{7}$ Kabuki é considerado o mais popular teatro tradicional japonês. Essa expressão é marcada pelo impacto e efeito visual levado aos extremos, com maquiagem altamente estilizada marcando os contornos dos olhos, os cílios e a boca. Cada cor está ligada a uma simbologia que representa o temperamento do personagem. É elegante e vulgar, cômico e trágico, desenvolvendo o tema central da peça por meio de canto, dança e representação. Arte tradicional com temas que abordam fatos da gente comum e também da vida aristocrática. Em sua origem somente mulheres atuavam em ambos os papéis: feminino e masculino, mas foi proibida devido à moralidade da época, que entendia a ação com apelo muito sexual. Após isso, passou a ser atividade masculina, mas acabou se degenerando e também foi considerada proibida. O kabuki conhecido hoje surgiu depois formado somente com homens, e o se transformar em mulher foi criado na época em que atores se especializavam nessa modalidade (HANDA, s.d.).

${ }^{8} \mathrm{O}$ teatro Nô tem na música, movimento e canto a arte da interpretação. Entre máscaras e instrumentos revela o lado tradicional da cultura japonesa marcado pelo simbolismo e pela simplicidade. $\mathrm{O}$ palco não tem cenário e a história se passa com poucos diálogos, por isso a interpretação depende muito de cada um, o que valoriza muito a presença do espectador. A máscara característica dessa expressão cobre o rosto do protagonista possibilitando a compreensão e expressão do personagem pelos movimentos e ritmo da música. O Nô é sofisticado, da nobreza, enquanto o teatro Kabuki tem uma linha mais popular (KIMURA, 2015).
} 
Manifestos arregimentaram grupos de artistas que buscavam abertura para estreitar a relação entre as atividades artísticas e a vida e surgiram como práticas de improvisação e espontaneidade, mas incorporavam técnicas de outras linguagens (COHEN, 2013). Constituíam-se em ensaios a partir de diversos elementos intrínsecos no fazer artístico, como negação da arte, naturalismo, liberdade da imaginação, sonhos, símbolos, objets trouvés, colagens, referências pós-guerra, fragmentação da imagem e imagem em movimento.

Um parentesco com a linguagem da performance é apresentado nos eventos futuristas ${ }^{9}$, cujas apresentações incluíam recitais, leituras de manifestos, dança, teatro e performances musicais.

Em meados do século XX, os futuristas haviam estabelecido solidamente a performance como meio de expressão artística independente. Em Moscou e Petrogrado (atual São Petersburgo), Paris, Zurique, Nova York e Londres, os artistas usavam-na como meio de transpor os limites dos diferentes gêneros artísticos, pondo em prática, com maior rigor, as táticas provocativas e ilógicas propostas pelos diferentes manifestos futuristas. Ainda que, em seus anos de formação, o futurismo parecesse consistir basicamente em tratados teóricos, dez anos depois o número total de performances nesses diversos centros era considerável (GOLDBERG, 2015, p. 19).

Esses artistas atraiam grande público, em 1913, em manifesto publicado na revista Argus, em São Petersburgo, declararam que não se restringiam a uma única manifestação estética, com seus rostos pintados, como síntese de ilustração e decoração, tendo como desdobramentos dois filmes, sendo Maiakovski protagonista de um deles. Essas ações fertilizaram o campo para a performance, declarando que "a vida e a arte tinham de se libertar das convenções e permitir a infinita aplicação dessas ideias a todas as esferas da cultura" (GOLDBERG, 2015, p. 23).

Outro exemplo foi no Variety Theater, em 1913, com apresentação do Manifesto; bem como o Cabaret Voltaire ${ }^{10}$, criado pela cantora Emmy Hennings (1885-1948) e pelo poeta Hugo Ball (1886-1927) em 1915 em Zurique (vide figura 3). O programa mesclava leituras de poemas, pinturas, performances musicais, e várias áreas artísticas, que atraiu outros artistas marcados pelo sofrimento oriundo da Guerra. Eles não estavam preocupados em criar algo novo.

\footnotetext{
${ }^{9}$ O Futurismo é o primeiro movimento que pode ser considerado de vanguarda, que sem dúvida anunciava a subversão radical da cultura e dos costumes sociais. Ao negar o passado substitui a pesquisa metódica pela experimentação estilística e técnica. É aberto com o manifesto de E. T. Marinetti (1878-1944), em 1909, em 1910 acontece o manifesto da pintura futurista assinado por G. Balla (1874-1958), C. Carra (1881-1966), U. Boccioni (1882-1916), L. Russolo (1885-1947). Em 1914 é assinado o manifesto de arquitetura futurista. Prampolini, Bragaglia, Depero e Dudreville foram responsáveis pela extensão da poética futurista para a cenografia e a direção teatral e também para o cinema (ARGAN, 2013).

10 "Cabaré Voltaire. Com esse nome formou-se um grupo de artistas e escritores, que tem por objetivo criar um centro de entretenimento artístico. A ideia do cabaré consiste em que artistas convidados se apresentem diariamente, fazendo performance artísticas e lendo suas obras" (GOLDBERG, 2015, p. 46).
} 
Ball advertiu que "o artista que trabalha a partir de sua imaginação independente está se iludindo a respeito de sua originalidade. Ele está usando um material já formado e, desse modo, o máximo que pode fazer é reelaborálo. Ao contrário disso, Ball apreciava o papel de catalisador" (GOLDBERG, 2015, p. 46).

Figura 3 - Cabaret Voltaire em Zurique em 1921

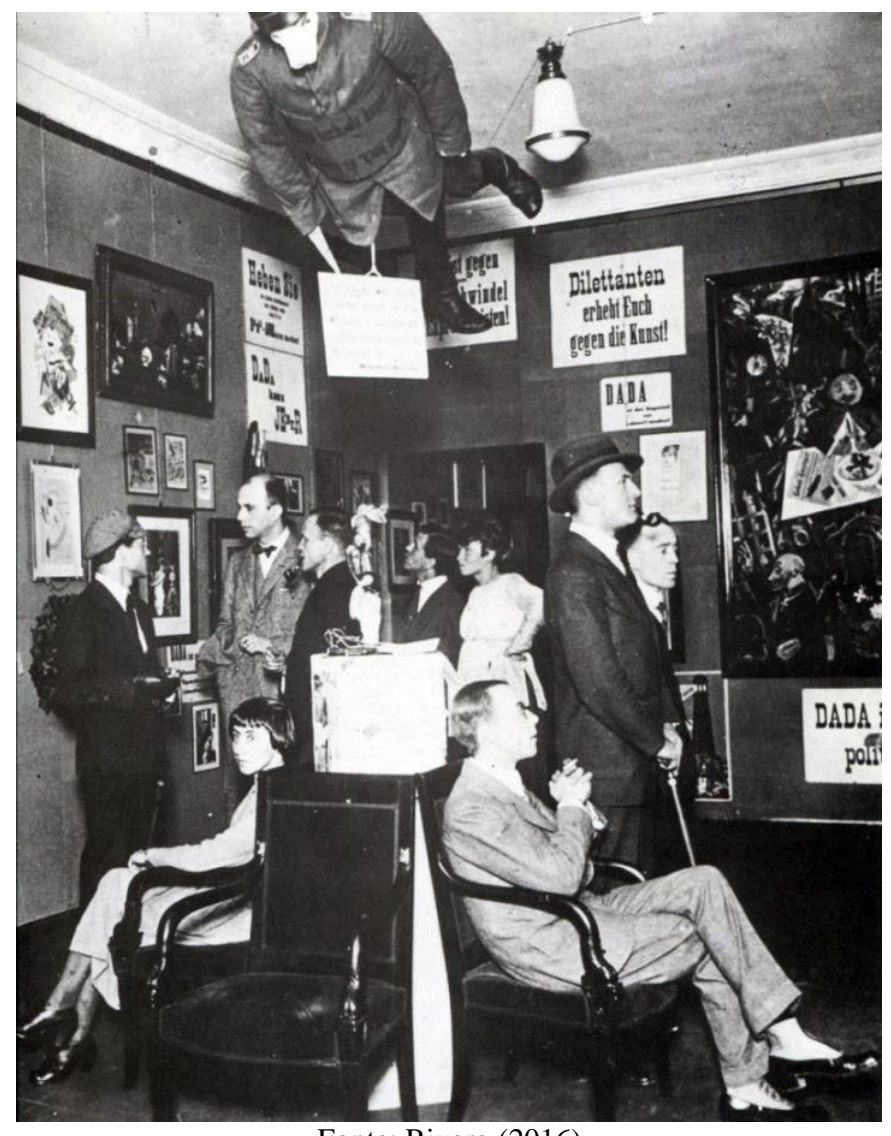

Fonte: Rivero (2016)

http://cultura.elpais.com/cultura/2016/01/27/babelia/1453915199_341191.html

Dentre esses artistas estava Tristan Tzara (1896-1963) que posteriormente, junto com outros artistas, constitui o movimento Dadá ${ }^{11}$, com a bandeira da antiarte e, em 1917, com Francis Picabia (1879-1956) e Marcel Duchamp (1887-1968) se tornou sinônimo de vanguarda artística (GLUSBERG, 2016).

A primeira exposição pública do Dada, em 1917, aconteceu na Galeria Corray, em Zurique, com a ideia de continuação do cabaré, mas com algumas mudanças, as performances com programas mais didáticos e organizados, e mais atenção para a dança,

${ }^{11}$ O nome Dada foi casual, escolhido ao se abrir um dicionário ao acaso. As manifestações desse movimento eram desordenadas, desconcertantes, escandalosas, ou seja, uma vanguarda negativa. Provavelmente o nome icônico foi de Marcel Duchamp e sua obra a "Fonte", de 1917. Ele comprou um urinol em uma loja, assinou e o enviou para uma mostra de arte. O movimento não queria produzir obras de arte, mas intervenções em série, imprevisíveis, insensatas, absurdas. O Dadaísmo rejeitava todas as experiências formais e técnicas anteriores, e utilizava materiais e técnicas da produção industrial, o readymade objeto qualquer apresentado como se fosse uma obra de arte, atribuindo-lhe valor. $\mathrm{O}$ valor estético era um ato mental, uma atitude diferente em relação à realidade. Os dadaístas colocavam a lógica e o acaso em categorias distintas e opostas, em uma relação dialética, sendo a lógica uma interpretação da lei do acaso (ARGAN, 2013). 
por ser mais direta. Mas a primeira performance foi na galeria L.B. Neumnn, em Berlim, com ações anárquicas e muitas provocações que acabaram entre aplausos de uns e de outros dentre o público presente e com intimidação do diretor da galeria ameaçando chamar a polícia (GOLDBERG, 2015). O resultado foi um escândalo estampado em várias manchetes e jornais, conduzindo para a segunda performance que foi minuciosamente elaborada, contou com distribuição de panfletos, além de introduzir o público a se relacionar com as ideias dadaístas.

Uma experiência estética importante aconteceu na renomada escola de Weimar na Alemanha, criada pelo arquiteto Walter Gropius (1883-1969), em 1919, na Bauhaus ${ }^{12}$, sob a direção de Oskar Schemmer (1888-1943) que objetivava a fusão das artes e artesanatos e a aproximação entre arte e industrialização, tema da I Semana da Bauhaus, em 1923, “Arte e Tecnologia: Uma Nova Unidade”. Outro aspecto foi o esforço em agregar as várias linguagens artísticas e experiências cênicas com pintura e escultura, relativas à utilização de espaços, como o trabalho "Figuras no Espaço e Dança no Espaço" (GLUSBERG, 2016). Essa escola, a Bauhaus, "é a primeira instituição de arte a organizar "workshops de performance"” (COHEN, 2013, p. 42), que foram pensados desde os primeiros momentos da escola como entendimento primordial do currículo.

O diretor de teatro Oskar Schlemmer, também pintor e escultor, tinha experiência com produção de dança e criou uma teoria da performance apoiada em manifestos próprios, referentes à oficina de teatro na qual analisava a dicotomia teoria e prática, por meio da mitologia de Dionísio e Apolo: "a teoria pertencia a Apolo, o deus do intelecto, enquanto a prática era simbolizada pelas selvagens festas de Dionísio" (GOLDBERG, 2015, p. 93). Em última análise, para Schlemmer, a performance proporcionava uma prática no espaço real, e, talvez por essa razão, Rastelli era um dos perfomers favoritos da escola, um artista circense, que fazia malabarismo, prática que se tornou comum entre os alunos com o intuito de desenvolver equilíbrio e coordenação.

Aspectos da Bauhaus foram a organização educativa estética e coletiva, a dedicação exclusiva dos artistas no sistema educacional e a eliminação do mercado.

\footnotetext{
12 Bauhaus significa "casa da construção". Em 1925, na Alemanha, devido à crença do fundador Walter Gropius que não acreditava na universalidade da arte e a colaboração de outros artistas instalou o pensamento de que o lugar do artista é a escola e sua tarefa social é o ensino. A Bauhaus com o propósito de rompimento entre arte e indústria produtiva e o vínculo entre artesanato e arte tinha caráter absolutamente democrático e foi fechada pelos nazistas em 1933. Trazia como princípio a pesquisa conjunta entre alunos e mestres, como uma sociedade que se autodetermina, como um núcleo formador da sociedade. Nessa teoria, a escola, ou centro de cultura artística predominava a tendência à geometrização das formas, não como cânone. Um determinante era projetar o espaço, que significa projetar a existência, sendo a recíproca verdadeira com atividade interdisciplinar. A Bauhaus revolucionou o design moderno ao buscar formas e linhas simplificadas e a construção de móveis foi elemento forte nessa escola. Outra característica marcante foi o fato de agregar as mais variadas expressões artísticas (ARGAN, 2013).
} 
Todavia, essas propostas se confrontavam com a sociedade burguesa gerida pelo mercado, pela lei de oferta, procura, produção e consumo, que entende a obra de arte como mercadoria (ARGAN, 2013). Todos esses mecanismos aguerridos corroboraram, de alguma forma, para fomentar a performance como linguagem artística.

Outro movimento dinâmico com interface com a performance foi o Surrealismo, que confrontava de frente o realismo do teatro tradicional, recheado com uma estética do escândalo como recurso para provocar o público com novidades, como peças sem textos apresentadas em teatros ou caminhadas, sempre chamando a atenção para essa nova tendência artística e ideológica (COHEN, 2013). Esse movimento, oficialmente fundado em 1925, com o manifesto surrealista, preconizava imaginação ilimitada, completa liberdade criativa, jogo do pensamento associado a outros elementos estéticos. Essas inquietações abasteciam a trajetória da performance e percorreram um longo caminho, até chegar ao status de arte e se firmar no universo das artes contemporâneas.

Evidentemente, outras ações, além das vanguardas do século XX estiveram presentes nas origens da performance, como a body art e happenings, expressões artísticas cujo instrumento era o corpo.

Essas formas de expressão artística, quando mapeadas, trazem em sua árvore genealógica um caleidoscópio de significados e processos criativos. É nesse contexto que a Liv $\operatorname{art}^{13}$ entra no cenário de arte marcada por uma forte participação e por retirar da vida real, ações cotidianas impregnadas e objetos simples da rotina diária, em simbiose com fantasias inconscientes, em um jogo no qual a casualidade era crucial (GLUSBERG, 2016). Um exemplo dessas ações foi abordado nos trabalhos do grupo japonês Gutai ${ }^{14}$, com trabalhos que propunham refletir questões pós-guerra em um país que vinha de uma cultura tradicional, com olhar para existência humana (figura 4). Um dos artistas, Saburo Murakami (1925-1996), em uma ação utilizou seu corpo para atravessar uma fila de telas de papel, rompendo o suporte pictórico com seu corpo; já seu parceiro, Atsuko Tamaka (1932-2005), utilizou lâmpadas fluorescentes para construir sua vestimenta. Da mesma

\footnotetext{
${ }^{13}$ Liv Art, termo que designa a confluência de diversas manifestações artísticas, por exemplo, artes plásticas, dança, teatro, música, cinema, vídeo e literatura, abrangendo uma variedade de disciplinas e discursos que envolvem, de algum modo, o tempo, o espaço e a presença humana. Muitos preferem não traduzir esse termo (GOLDBERG, 2015).

${ }^{14}$ O Gutai Bitjutsu Kyokai (Grupo Gutai) foi formado por Yoshihara Jiro, em 1954, em Ashiya, cidade perto de Osaka, no Japão. Realizou as primeiras manifestações de Arte Corporal Performances, Arte Conceitual e pesquisas minimalistas. O grupo teve repercussão internacional, devido a uma revista bilíngue a partir de 1955. Os trabalhos de Yoshihara foram pinturas, esculturas, instalações, espetáculos, pelos processos mais variados. O criador apresentou o Grupo Gutai em 1955: "Nós desejamos trazer de maneira concreta a prova que nossos espíritos são livres. (...) Nós queremos estabelecer ligações com o conjunto daqueles que criam nas artes visuais, que se trate de caligrafia, de ikebana, de artesanato ou de arquitetura. (...) Isto nos encoraja a multiplicar as colaborações, a nos aproximar de todas as outras formas de arte contemporânea: os desenhos de crianças, a literatura, a música, a dança, o cinema ou o teatro" (MEDEIROS, 1999, p. 1).
} 
forma, Kazuo Shiraga (1924-2008), por meio de pantomimas, pintava quadros com os pés. Essas propostas apontavam que o corpo pode ser suporte da pintura, bem como o espaço.

Figura 4 - Grupo Gutai: Saburo Murakami - Atsuko Tamaka - Kazuo Shiraga, 1956/1960

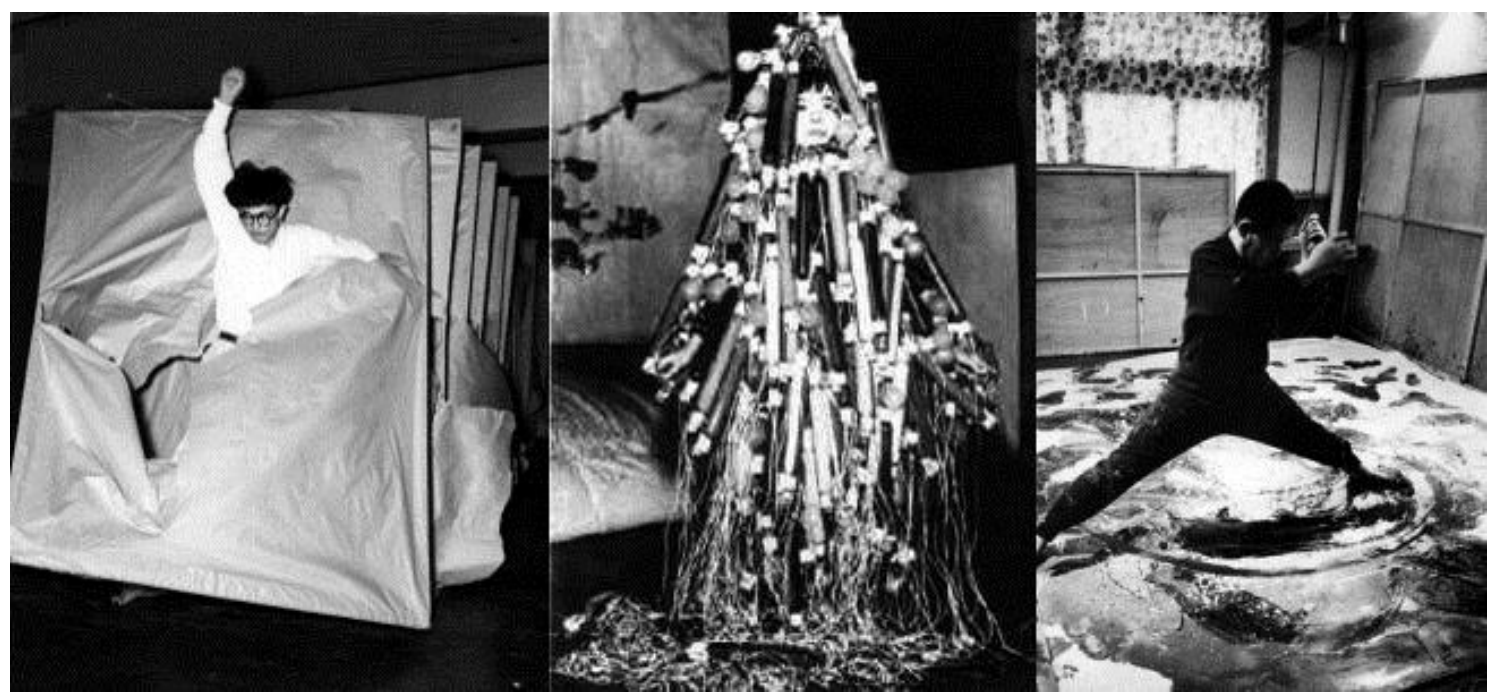

Fonte: Superficiedosensivel (2013)

https://superficiedosensivel.wordpress.com/2013/03/05/grupo-gutai/

Abordado anteriormente, o happening desabrocha a partir da contracultura e produções experimentais no campo das artes cênicas, com propostas de cunho humanista. Essa forma de expressão agregou várias tendências inovadoras da época, questões rituais como o teatro de $\operatorname{Artaud}^{15}$, a dialética de Brecht ${ }^{16}$, o olhar para dança por Martha Grahan (1894-1991) ou Yvonne Rainier (nascida em 1934), conforme figuras 5 e 6, e até mesmo o laboratório de Grotowski ${ }^{17}$ (COHEN, 2013). Por outro lado, as artes plásticas, as obras

\footnotetext{
${ }^{15} \mathrm{O}$ ator, diretor, poeta e teórico francês Antonin Artaud (1896-1948) foi o responsável pelo Teatro da Crueldade na década de 1920, com o objetivo de criticar a cultura do espetáculo e a visão da sociedade ocidental. Os movimentos Dada e Surrealismo foram preponderantes para essa prática e, em 1932, foi publicado o Manifesto do Teatro da Crueldade. Esse essencialmente criticava a racionalidade do mundo ocidental, em contrapartida a uma nova concepção de teatro e apreensão do universo, com a premissa de que o teatro deveria abalar as certezas adotadas pela sociedade. Tratava-se de um teatro sensorial e intuitivo, além de promover o diálogo entre o palco e o público, atores e espectadores. No Brasil, o Teatro Oficina colocou em prática o pensamento de Artaud com as peças: "O Rei da Vela", "Roda Viva" e "Na Selva das Cidades" (DEL, 2011).

${ }^{16}$ Bertolt Brecht (1898-1956) dentre vários trabalhos foi colaborador de diversas revistas de refugiados da Segunda Guerra Mundial. Ele escreveu canções, diários de trabalho, ensaios, um roteiro de cinema com o cineasta Fritz Lang e poesia. Em 1949, Brecht fundou Berliner Ensemble, grupo teatral que o acompanharia até o fim da vida, em parceria com sua esposa e atriz Helene Weigel. Segundo José Fernando Azevedo (s.d., s.p.), do grupo Teatro de Narradores e professor da Escola de Arte Dramática da USP: "Ler Brecht nos ajuda a entender como é possível interrogar o tempo presente. (...) Brecht nunca colocou em cena a utopia, mas tentou se interrogar sobre as condições que poderiam desencadear a transformação". Provavelmente sua maior contribuição foi ter criado recursos teatrais simultaneamente estéticos e políticos em oposição ao teatro aristotélico (CLARO; MARETTI, 2011).

${ }^{17}$ Grotowski (1933-1999) acreditava que tudo deveria vir do corpo: "antes de reagir com a voz, deve-se reagir com o corpo. Se se pensa, deve-se pensar com o corpo inteiro, através de ações." Ele procurou no corpo maneiras de se representar como fonte de energia, ao mesmo tempo que para ele há entre o ator e o espectador um efeito de abalo como um acontecimento que pode transformar o espectador. Grotowski se
} 
de Jackson Pollock (1912-1956) com action painting (figura 7), nas quais a ação do pintor no ato da criação é tão importante quanto o resultado plástico, no qual o processo quase coreográfico de pintura já dava indícios de rupturas e vanguardas técnicas: "que transforma seu ato de pintar no tema da obra, e o artista em ator" (GLUSBERG, 2016, p. 27). Nesse período, o artista começa a utilizar o corpo como instrumento na sua relação com o público, no espaço-tempo e na busca incessante por novas formas de expressão, diferentes técnicas e produção artística.

Figura 5 - Martha Grahan - Salem Shore, 1935

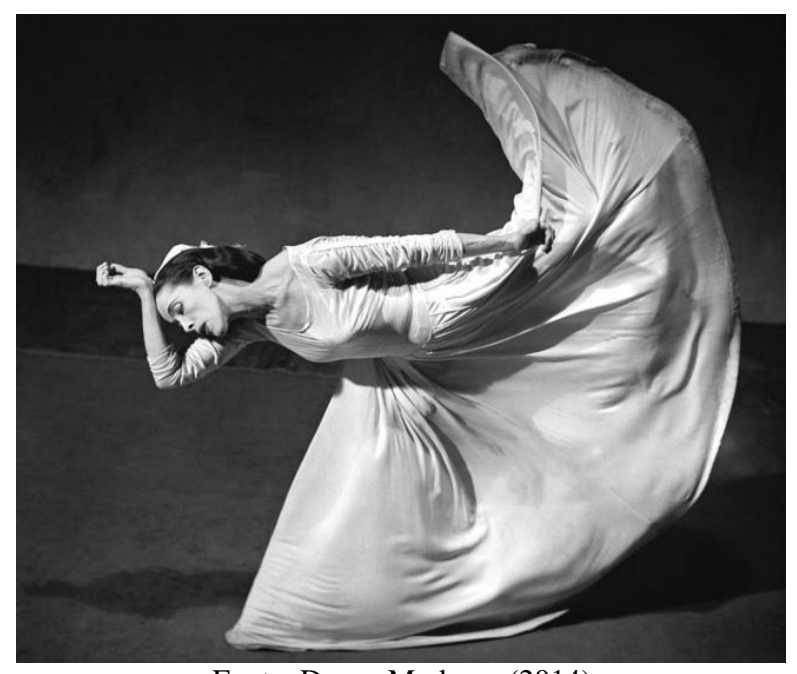

Fonte: Dança Moderna (2014)

http://dancamoderna.com.br/2014/musa-moderna-marthagraham-um-pouco-da-sua-historia/
Figura 6 - Yvonne Rainier, 1965

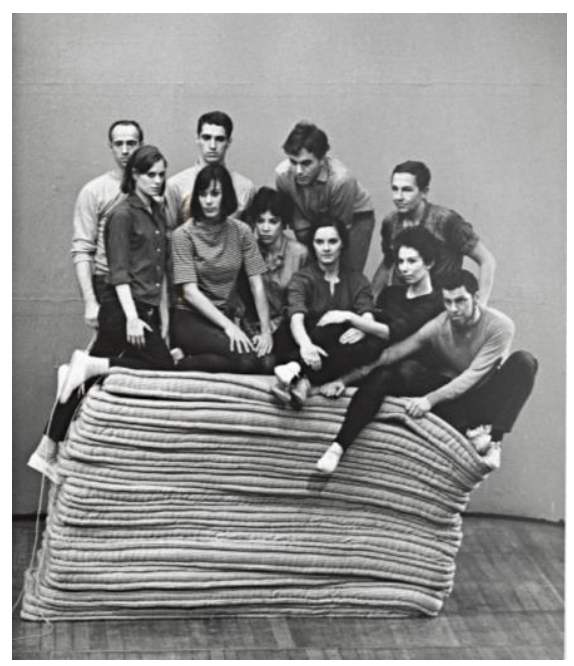

Fonte: Sleek (2012)

http://www.sleek-mag.com/2012/03/28/keren-cytteron-swan-lake-beauty-and-yvonne-rainer/

Outros artistas, nos anos 1970, também utilizaram o corpo como ferramenta em sintonia com as artes plásticas. Isso fica evidente em um trabalho de Yves Klein (19281962), que apresenta modelos nus besuntadas com tinta azul, que estampavam seus corpos em telas brancas, no ritmo de uma orquestra executando a Sinfonia Monótona de Pierre Henri (1927-2017), como se os corpos fossem pincéis vivos. Segundo o autor, o objetivo era aprofundar ao máximo a action painting (vide figura 7). No mesmo período, Piero Manzoni (1933-1963), em 1961, introduziu algo inusitado: ele assinava parte de corpos humanos, tornando-os obras de arte (GLUSBERG, 2016).

refere ao ator - performer: "O Performer com maiúscula, é um homem de ação. É o dançante, o sacerdote, o guerreiro (...) o performer deve trabalhar em uma estrutura precisa, fazendo esforços, porque a persistência e o respeito pelos detalhes são o rigor que permite fazer presente o eu-eu. As coisas por fazer devem ser exatas. Da mesma forma acredita que o ator é um homem que trabalha em público com o seu corpo, oferecendo-o publicamente, afinal o teatro é 'um ato de viver' e 'um caminho de existência"” (TOLENTINO, 2005, p. 1). 
Figura 7 - Jackson Pollock - Action painting

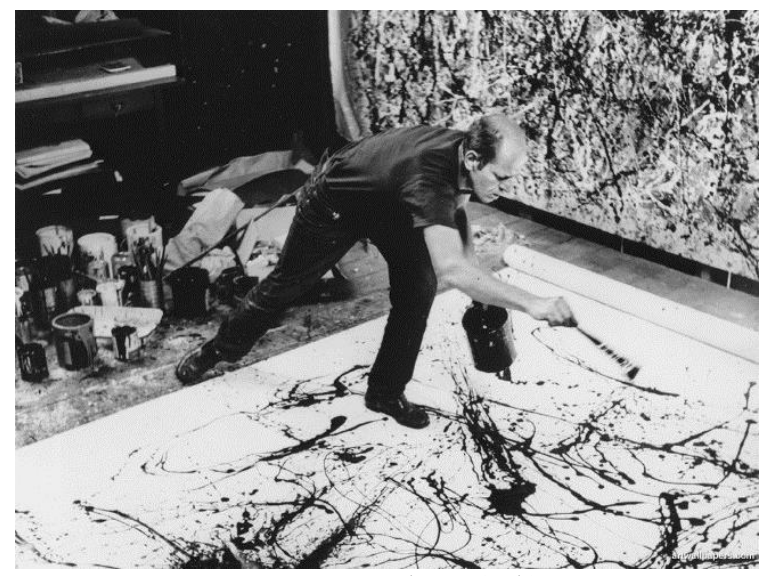

Fonte: Koppelman (s.d.)

http://terraingallery.org/art-criticism/jackson-pollock-andtrue-false-ambition-the-urgent-difference/
Figura 8 - Yves Klein - Orquestra ao fundo toca Sinfonia Monotônica, de uma nota só

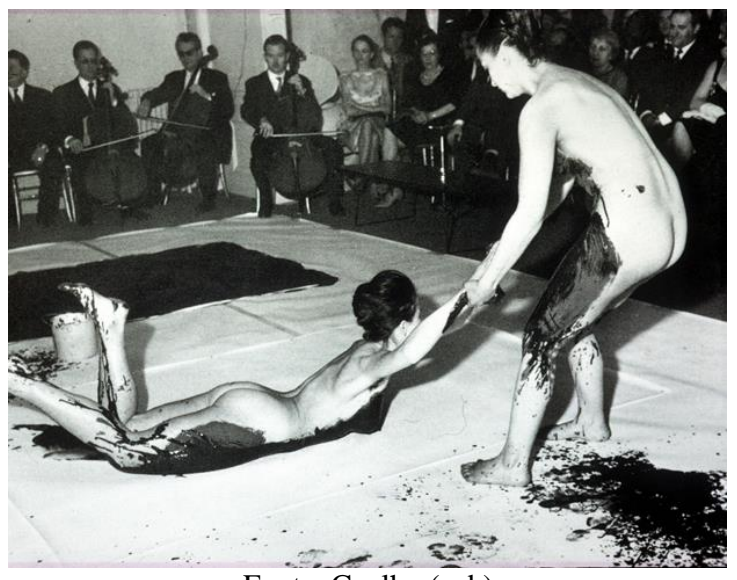

Fonte: Coelho (s.d.)

http://hardecor.com.br/yves-klein/

Uma questão importante é a performance ser um desdobramento da body art, que utiliza o corpo, a presença física do artista, como elemento fundamental da obra, quase transformando o artista na própria obra de arte. Muitos artistas embarcaram em propostas com esse conceito, caso do Grupo Fluxus ${ }^{18}$ (vide figura 9), de George Maciunas (19311978), que propôs um pacote de ações que extrapolou tanto o happening, a dança, o teatro, a música e a poesia, e não diferenciava arte de não-arte, individualidade e institucionalização, mas procurava o natural, o simples (GLUSBERG, 2016). A body art utiliza o corpo como matéria prima, mas a prática transcende o corpo, incorpora outras questões individuais e coletivas, sociais; objetos e espaços de criação e exibição, que vão além das instituições; certificam que o corpo humano é fonte de produção de signos. Esses conteúdos desenvolvidos em manifestações diversas levam à linguagem da performance, que valoriza o processo, a produção artística; e impregna essas manifestações, em um diálogo direto com o público, recolhendo ritos e cerimônias, e se identificando com a vida e o cotidiano do homem.

\footnotetext{
18 “'Fluxus é um modo de fazer coisas [...], uma forma de viver e morrer', com essas palavras o artista americano Dick Higgins (1938-1998) define o movimento, enfatizando seu principal traço. Menos que um estilo, um conjunto de procedimentos, um grupo específico ou uma coleção de objetos, o movimento Fluxus traduz uma atitude diante do mundo, do fazer artístico e da cultura que se manifesta nas mais diversas formas de arte: música, dança, teatro, artes visuais, poesia, vídeo, fotografia e outras. Seu nascimento oficial está ligado ao Festival Internacional de Música Nova, em Wiesbaden, Alemanha, em 1962, e a George Maciunas (1931-1978), artista lituano radicado nos Estados Unidos, que batiza o movimento com uma palavra de origem latina, fluxu, que significa fluxo, movimento, escoamento. O termo, originalmente criado para dar título a uma publicação de arte de vanguarda, passa a caracterizar uma série de performances organizadas por Maciunas na Europa, entre 1961 e 1963. (...) As músicas de John Cage e Paik, comprometidas com a exploração de sons e ruídos tirados do cotidiano, têm lugar central na definição da atitude artística do Fluxus. Trata-se de romper as barreiras entre arte e não arte, dirigindo a criação artística às coisas do mundo, seja à natureza, seja à realidade urbana, seja ao mundo da tecnologia. (...) As performances conhecem inflexões distintas, podendo adquirir tom minimalista ou acento mais teatral e provocador" (ITAÚ CULTURAL, 2017, p.1)
} 
Figura 9 - Grupo Fluxus

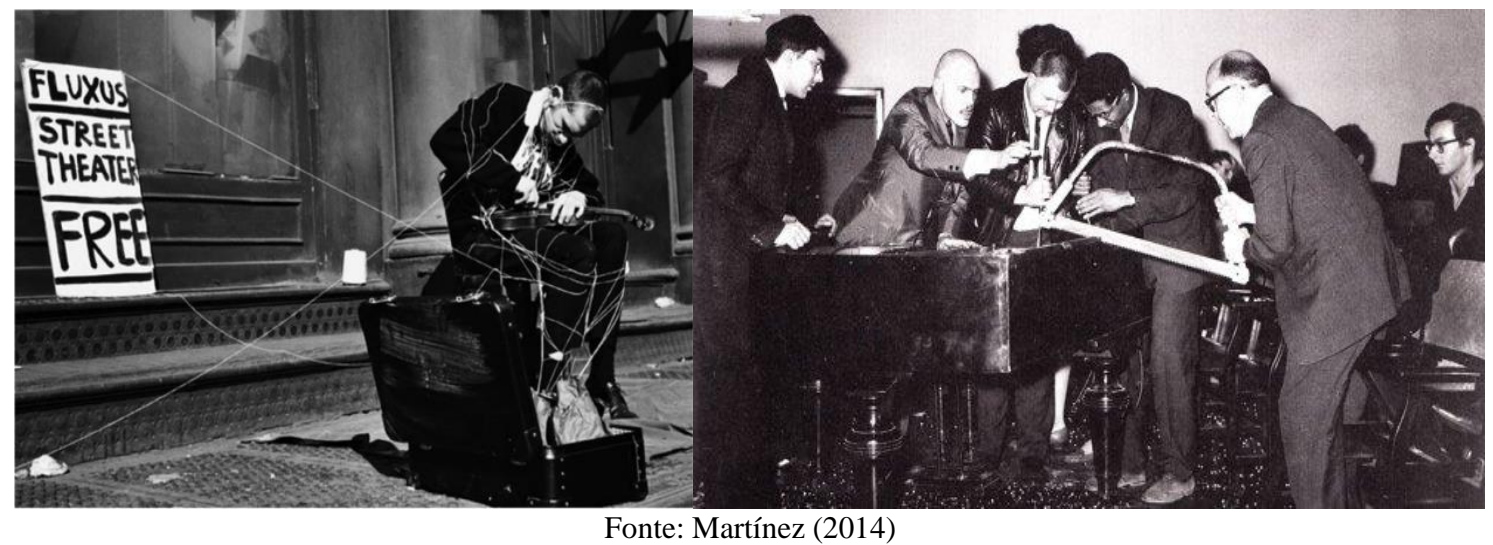

http://culturacolectiva.com/fluxus-la-revolucion-del-arte/

O processo criativo apontava para além das fronteiras do produto final, "a obra de arte". Esse aspecto mereceu atenção de alguns pesquisadores como Richard Schechner (2006), que destacou a intimidade da performance com os rituais, as memórias em ação, e as qualidades da linguagem: “A primeira qualidade da performance é a ação corporal. $O$ arquivo está lá, mas para mim o repertório é muito mais preponderante e importante porque é através do repertório, do comportamento em ação, que o processo continua gerando mudanças constantes" (SCHECHNER, 2006, p. 28).

Essa forma de linguagem talvez traga em seu arcabouço a qualidade de romper limites, principalmente entre arte e vida, entre expressão e ação e, por fim, entre novos meios de expressão, seja pela natureza, pelo místico, pelo cerimonial, pelo cotidiano, pelo corpo.

A performance traz em sua curva narrativa uma bagagem imbricada de significados e ações, desde suas primeiras manifestações, esse caminho experimentou várias questões inclusive quanto a sua nomenclatura, que hoje parece estar sedimentada como expressão artística. A performer e professora de performance Juliana Moraes (2016) acredita que a nomenclatura performance nasceu nos anos 70 e foi usada especialmente por artistas como Marina Abramović ${ }^{19}$.

Anteriormente, preferia-se o termo happenings e, no Brasil o artista Flávio de Carvalho (1899-1973) incluiu caminhadas em suas manifestações artísticas, nas quais

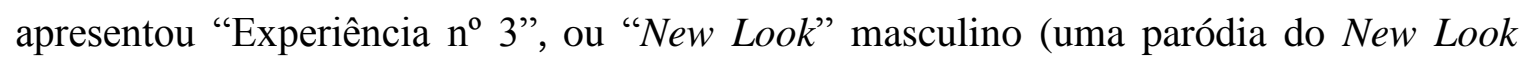

\footnotetext{
${ }^{19}$ Marina Abramovic, artista há mais de três décadas, atua no campo da performance, estudou na Academia de Belas Artes de Belgrado, e logo depois na Academia de Belas Artes em Zagreb, onde mais tarde lecionou. Em 1970 começou a trabalhar com ambientes sonoros, cinema, vídeo e performance. Trabalhando de forma independente, ela exibiu, realizou e ensinou internacionalmente, estabelecendo uma intimidade singular com a história da performance. Marina tem ensinado por mais de 20 anos, mas ela própria decidiu não ensinar, pois quer cuidar dos alunos, e deseja ser responsável pelo destino desses alunos, e estes devem realmente levar as ideias e tentar mudar o resto. Outro aspecto relevante é o termo "re-performance" ligado a sua história e seu trabalho (THOMPSON; WESLIEN, 2006).
} 
feminino de Christian Dior) por ele concebido: "blusão de mangas curtas e folgadas e saiote de pregas largas" (ESCRITÓRIO DE ARTE, 2010), uma espécie de saiote masculino, com o qual caminhou pelo centro de São Paulo. Segundo Flávio, os homens brasileiros deveriam usar saia, devido ao clima tropical do Brasil, a saia ou saiote por ele idealizada tinha um dispositivo, que quando acionado movimentava a saia, criando ventilação. Ele preferia utilizar o termo "experiências", por dialogar muito mais com o universo das artes visuais (figuras 10 e 11). O termo é utilizado também no campo das artes cênicas, da dança e do teatro com a ideia de obras performáticas (MORAES, 2016).

Figura 10 - Flavio de Carvalho, New Look, passeata por São Paulo, 1956

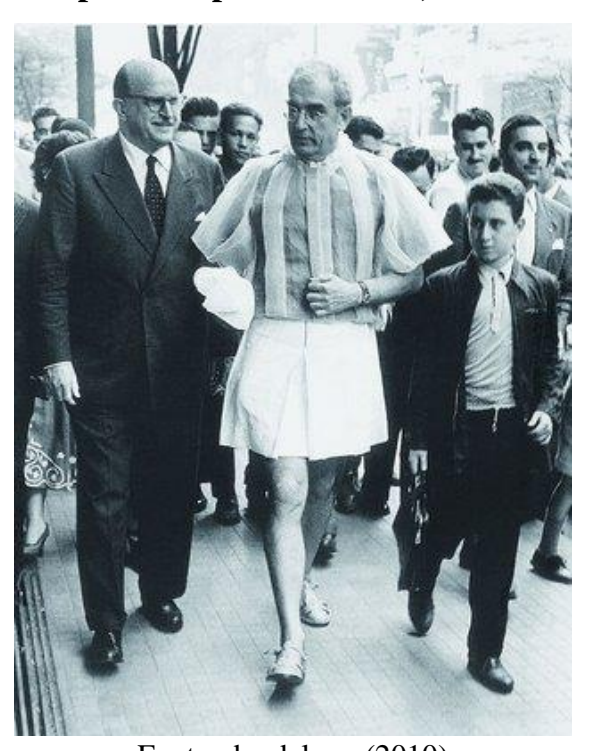

Fonte: duodeluxo (2010)

https://duodeluxo.wordpress.com/2010/11/15/fl

avio-de-carvalho-desveste-a-moda/
Figura 11 - Revista O Cruzeiro, nov. 1956

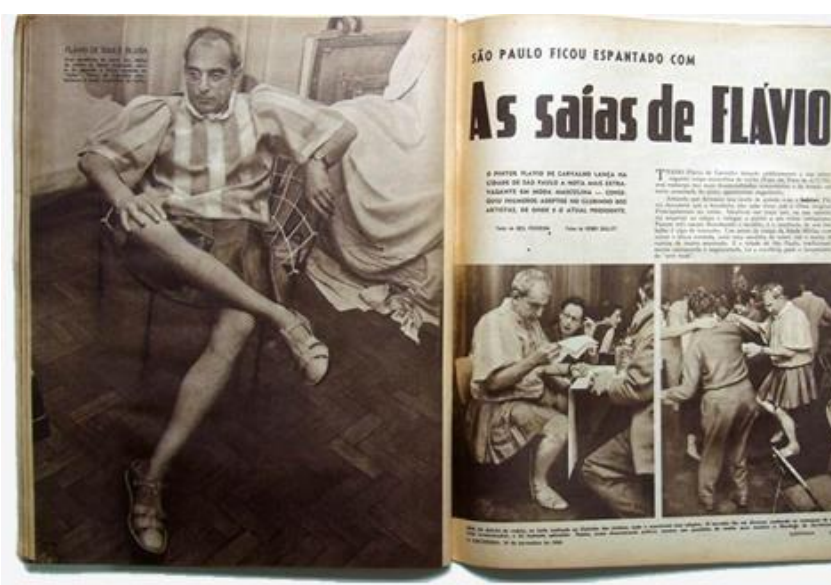

Fonte: A cidade do hímen $\mathrm{Nu}(2010)$

http://acidadedohomemnu.blogspot.com.br/2010/04/flav io-de-carvalho.html

Outros artistas também estiveram no cenário performático brasileiro, com ideias significativas, deixando um legado sofisticado de produções artísticas ligado a tradições locais, rituais folclóricos, como Hélio Oiticica e Lygia Clark.

(...) cujas construções efêmeras e formas corporais foram concebidas como objetos interativos de desengajamento, tanto estético como social. Poética e utilitária, cheia de metáforas cujo significado é bem conhecido por um grande público nas ruas de São Paulo, Rio de Janeiro ou Salvador, a natureza simbólica de grande parte dessas obras emerge das festas populares e das procissões de santos e divindades, que permeiam todo o calendário anual (GOLDBERG, 2015, p. 230).

No panorama internacional se destaca a trajetória da performer Marina Abramović nascida em Belgrado, Sérvia, filha de comunistas que lutaram contra os nazistas, e a mantinham em disciplina militar, levando Marina aos 29 anos a se mudar para Amsterdã, onde conheceu o artista plástico Ulay, seu parceiro de performances, produzindo grandes 
obras juntos. Finalizaram a relação com uma caminhada de 2.500 quilômetros na Muralha da China, em 1988.

Provavelmente sua maior habilidade esteja na forma como utiliza o próprio corpo, levando-o aos limites físico e mental, chegando a se mutilar em algumas encenações, como na ocasião que se cortou com uma lâmina, ou ao escovar o cabelo até sangrar. Certamente, sua obra ícone foi sua performance The Artist is Present no Museum of Modern Art (MoMA), sediado em Nova Iorque, na qual ficava sentada em uma cadeira de madeira por sete horas. Talvez por essas opções, ela é considerada a figura emblemática da performática (MORISAWA, 2012,). Marina afirma que sua arte é como uma marca, e quando seu nome está em algum lugar, isso significa que é performance (MORISAWA, 2012). Falar de Marina Abramović é, portanto, quase sinônimo de performance.

Um aspecto a ser considerado na trajetória da arte, provavelmente marcada por algumas rupturas, foi a necessidade da eliminação do suporte (quadro), que pode apontar alguns caminhos, inicialmente o papier collé dos cubistas, cujo objeto começa a fazer parte da pintura, que em determinado momento teve a presença de objetos, texturas e materiais colados na obra, dando origem a outra maneira de se fazer pintura, ou não pintura. Mas foi com Marcel Duchamp e seus ready-made, que o cenário das artes encontra uma das maiores revoluções estéticas: objetos manufaturados são colocados em instituições de arte e apresentados como obras artísticas. Nesse mesmo contexto, os surrealistas com a condição de objet trouvé propuseram um deslocamento do objeto, do seu contexto natural para outra realidade, buscando estranhamento. Sem dúvida foram comportamentos que mudaram o pensamento dos artistas e da sociedade. Daí ao abstracionismo, a não figuração. O caminho foi breve e a imagem pictórica foi substituída por um olhar mais amplo, impulsionando o espectador a ver e a sentir para além do objeto. Essa jornada ressalta alguns aspectos do nascimento da performance, pelo seu olhar novo do fazer artístico, ampliando esse universo de forma significativa.

De acordo com Felipe Chaimovich (2016), curador do Museu da Arte Moderna de São Paulo [MAM-SP], a origem das performances são os quadros-vivos, que são a origem também do teatro religioso cristão europeu, a partir do século XIII. Já o performer e pesquisador Renato Cohen (2002, p. 28), em suas reflexões, esclarece:

Apesar de sua característica anárquica e de, na sua própria razão de ser, procurar escapar de rótulos e definições, a performance é antes de tudo uma expressão cênica: um quadro sendo exibido para uma plateia não caracteriza uma performance; alguém pintando esse quadro, ao vivo, já poderia caracterizá-la. 
Assim, a performance, por ser linguagem artística de vanguarda, pode ser considerada como expressão cênica de linguagem híbrida, que tem relação direta com a dança, com o teatro, com a representação. De certa forma, tenta uma aproximação com a vida, que tende a procurar o natural e o espontâneo, ações como andar, dormir, comer, falar e/ou se movimentar. Essas ações acabam normalmente no ato da representação, deixando impressões e questionamentos àqueles que a vivenciaram, diferente do que ocorre com as artes plásticas, que são objetos físicos que permanecem e tendem a resistir ao tempo, porém, nem por isso a performance não se encontra no mesmo patamar artístico porque: "O trabalho artístico, (...) é na verdade um modo através do qual o artista se constrói fora de si, dá permanência e objetividade a sua fantasia (...) deflagra no seio da banalidade, o maravilhoso, o poético, o dramático, o inesperado" (GULLAR, 1993, p. 19).

De alguma forma, o fato dessa linguagem trabalhar no campo da imaterialidade, na qual o processo e o conceito são abordagens significantes não tem facilitado seu ingresso em coleções e acervos, como é natural e comum nas artes plásticas. Contudo, devido ao engajamento e atuação dos artistas desse segmento, a performance tem ganhado espaço em feiras de arte, exposições e mostras em galerias, catálogos e, principalmente, em acervos de instituições públicas sediadas em São Paulo/Brasil. Isso sinaliza que apesar de surgir em um processo de ruptura e confronto com as instituições, já consta em acervos que há pouco dispunham somente de obras materiais. Essas questões levam a várias reflexões, perguntas e dúvidas, que nas sutilezas e metáforas do universo das artes vêm encontrando ambientes favoráveis de debates e aprofundamentos para fruição dessa expressão, que a cada dia amplia sua envergadura tanto no cotidiano da sociedade, quanto em instituições tradicionais, como museus que asseguram a guarda da memória cultural de seu povo.

\subsection{O DISCURSO PERFORMÁTICO}

A arte não é apenas expressão da subjetividade do sujeito, mas sua construção. $\mathrm{O}$ indivíduo não pode apenas estar sujeito às afecções do cotidiano, mas deve tornar-se atuante, mudar seu discurso mudar sua natureza. Mas, como temos visto, as palavras nem sempre são suficientes e é preciso algum trabalho de campo, mesmo que esse empenho possa parecer, a princípio, com uma dança de desorientados (GALLON, 2015, p. 42).

O termo performance tem sua etimologia do latim, "per-formare", que se refere a realizar. Em inglês, o termo tem sua origem no francês antigo, do século XVI, e significa: 
execução, desempenho, realização, ação, habilidade, cerimônia, rito e até espetáculo, mas com significações que necessariamente não remetem à expressão artística, nem caracteriza ou define a arte da performance (GLUSBERG, 2016). Nesse sentido, Richard Schechner (2006) acrescenta outros significados relativos ao termo performance: ter qualidade, padrão de excelência e sucesso, seja nos negócios ou esportes, bem como realizar performance como atributo de se mostrar fazendo, sendo, e fazendo e explicando simultaneamente. Essa abordagem de Schechner compreende ações, fluidez, e na categoria filosófica compreende o "esforço reflexivo para compreender o mundo da performance e o mundo enquanto performance" (SCHECHNER, 2006, p. 28).

No campo das artes, a performance não pode ser apreciada, sem levar em consideração seu contexto histórico e o meio cultural na qual se insere, ao mesmo tempo em que é um questionamento do natural e uma concepção artística, com aspectos individuais, sociais: "o artista na sua própria obra, ou melhor ainda, em sujeito e objeto de sua arte" (GLUSBERG, 2016, p. 43). Considera-se que toda ação humana e artística nunca está isolada, vem impregnada de histórias e contextos, sejam eles do criador ou do tempo e espaço onde ela ocorra, ficando muito difícil isolar o ato apenas no indivíduo autor, mesmo porque toda ação tem resposta, que de alguma forma interfere direta ou indiretamente na obra.

A performance, por ter caráter híbrido ou de fronteira, envolve outras áreas artísticas de conhecimento, e pode ter suas origens em vários movimentos artísticos. Inclusive o termo "performance" pode ser considerado como desdobramento de outras manifestações artísticas, o que propõe várias leituras, dentre as quais: aspectos sociais, rituais, comportamentais, linguagens corporais, interatividade, novas mídias, vida cotidiana, dentre outras questões que podem levar a uma pergunta: onde acontecem as performances?

\footnotetext{
Uma pintura "acontece" em seu objeto físico; um livro acontece nas palavras. Mas uma performance acontece enquanto ação, interação e relação. Deste modo, uma pintura ou um romance podem ser performativos ou serem analisados "enquanto" performances. A performance não está "em" nada, mas "entre" (SCHECHNER, 2006, p. 30).
}

Na performance o artista utiliza seu corpo, o de outra pessoa e/ou de um grupo, além de materiais e diversas linguagens que conversam entre si. Apresentam informações que compõem um novo panorama e entram em contato direto com o público. $\mathrm{O}$ fato de um artista, o performer, conceber uma ação e, por vezes, outro a executar, pode trazer questionamentos quanto à autoria, porém, essa prática também ocorre em outras 
linguagens artísticas, como na relação do ator e do diretor, do coreógrafo e o bailarino, do escritor, do roteirista e do diretor no cinema, bem como em um projeto de arquitetura.

O valor de autoria está mais no conceito, com um arquiteto, que projeta, ninguém vai questionar a autoria de um prédio, por que o arquiteto não pôs a mão no tijolo, não fez os cálculos, o engenheiro, o mestre de obras, o operário, ele está executando um projeto, e as artes têm se aproximado desse modelo, embora para o grande público seja um pouco difícil, para o meio [artístico] isso já está mais claro, o artista não tem que ser um técnico fazedor (ALVES, 2016, p. 5.).

Por vezes, essa linguagem é efêmera, assim como é a realidade do artista que a cria e executa, do contexto em que está inserida.

Ainda como ruptura, a performance como linguagem artística se diferencia, desde o século XX em sua fase inicial, por ser de vanguarda, pela característica de contestação na qual o artista é sujeito e objeto de sua obra. Segundo Cohen (2013, p. 30), poderia se dizer: "numa classificação topológica, que a performance se colocaria no limite das artes plásticas e das artes cênicas, sendo uma linguagem híbrida que guarda características da primeira enquanto origem e da segunda enquanto finalidade". Essas características enriquecem a expressão, em contrapartida dificultam sua conceitualização. De acordo com Richard Schechner (2006, p. 8), trata-se do "comportamento restaurado", que segundo esse autor é um processo principal de todos os tipos de performance: “(...) sou eu me comportando como se fosse outra pessoa" ou "como me foi dito para fazer", ou "como aprendi". Esse aspecto da linguagem amplia o olhar e a dimensão na qual a performance pode intervir na fruição da arte.

Performers em suas apresentações, em geral, abordam um pouco desse jogo, ora são personagens, ora pessoas reais interagindo com o público. Apesar de aparente composição teatral, esses artistas não desenvolvem estrutura aristotélica (com começo, meio e fim, em uma linha narrativa). "O apoio se dá em cima de uma collage como estrutura e num discurso da mise em scène" (COHEN, 2013, p. 57).

Entretanto, a performance quebrou paradigmas, algumas ações são criação de um performer para execução de outros artistas, questionando a habilidade, destreza artesanal desse artista, criador do conceito. São questões como essa que abrilhantam a linguagem e realçam o debate sobre o fazer artístico: “(...) como já dizia Da Vinci, a arte é uma coisa mental, está em grande parte na concepção, e dependendo do processo a concepção está no fazer, e algumas performances estão no fazer, isto é fundamental, outras [coisas] não" (ALVES, 2016, p. 5).

É importante ressaltar que em meados dos anos 1960, a experimentação cênica com objetivos humanistas foi fonte dos praticantes da contracultura, do desejo de artistas 
em conceituar tendências de multilinguagem que para alguns estava na ação, na fusão ou na atuação. Alguns artistas começaram, por exemplo, com a utilização do corpoinstrumento, relação espaço-tempo com o público, na qual habitou a body art (COHEN, 2013).

Por outro lado, há conceitos de artes performáticas, que compreendem dança, teatro e as artes com a presença dos artistas. A partir dos anos 70 passa-se a considerar "o entendimento que performance é um desdobramento da escultura, intrínseco com as artes visuais" (MORAES, 2016, p. 1).

Argumentos mais ácidos são apresentados nessa abordagem, como aponta Gullar (1993), que acredita que muitos artistas vanguardistas, no intuito de fugir à institucionalização e à alienação, questionam sua própria linguagem e o fazer artístico, chegando a destruí-la e banalizando o próprio trabalho. Segundo Gullar (1993), o artista pode transformar seu trabalho e ideal antiartista em produção de performance, na qual ele tira a roupa no museu, ou faz instalações que se desmontam, enfim obras datadas e efêmeras à procura de visibilidade nas mídias, sem valor durável. Adota o espírito da cultura consumista, na qual a fama é o extrato final do trabalho, que por inúmeras vezes é patrocinado por instituições oficiais, mesmo que esse pensamento tenha sido iniciado pela renúncia aos valores burgueses.

Outra característica, apontada por Gullar (1993, p. 43), é a procura pelo novo, questão da condição humana. Uma obra nova de qualquer artista sempre "guarda consigo algo do passado, não pode ser radicalmente nova". Afinal, é difícil se ter alguma coisa totalmente nova, porque o artista sempre traz seu repertório para o âmago da obra, sua vida, o meio em que vive, os artistas e pensadores que lhe inspiram, os materiais com os quais trabalha, de alguma forma são realinhados e captados no fazer artístico, mesmo quando se procurar inovar ou ser original, substratos do passado direto ou transversalmente que impregnarão esses trabalhos.

O novo na arte é um encadeamento de significações. Contudo, o novo deve cuidar para não se confundir com a teoria evolucionista da arte, que percebe o valor estético como o resultado de sua evolução. Certamente, uma pergunta se faz: é possível a arte evoluir? A arte se altera e o mesmo acontece com a trajetória de um artista, pois segundo essa teoria, a cada passo seu trabalho deveria ser melhor, superior, e obviamente isso não é uma premissa. Um exemplo a se considerar é o encantamento causado pela arte grega até os dias atuais, que em tese não são mais evoluídos do que expressões de artistas de séculos posteriores (GULLAR, 1993). Porém, esse celeiro de eficiência e talento pode encontrar uma justificativa na admiração que nutre por esses produtos artísticos, e, ainda, 
uma hipótese pode se formular: há períodos mais oportunos ao crescimento artístico que outros, contudo, essas obras não traduzem a veracidade de outro período histórico.

Conceituar, definir ou classificar performance, portanto, não é algo simples, devido a sua característica híbrida, de fronteira, e por estar inserida em diversos campos do conhecimento - antropologia, cultura, música, artes plásticas, dança, teatro. Essa linguagem, assim como as artes contemporâneas, não se pauta em traduzir significações, que para o apreciador em alguns momentos podem não ser claras, mas são habitadas por significados, experiências e muitas metáforas. A ação do performer é tarefa que exige pesquisa, discernimento, estudo e dedicação, principalmente, por sua característica efêmera. O predomínio da ideia sobre o objeto, da arte conceitual, na qual o processo e o conceito são o âmago e a essência dessa linguagem aponta diretamente para a performance. Vários são os aspectos relevantes, sobre eles Glusberg (2016, p. 31) afirma: "O fio condutor da collage nos permitiu observar as mutações que ajudaram o nascimento da arte performática".

Outros aspectos encontrados na performance surgem em um contexto de protestos e reivindicações políticas, negação do objeto artístico, reação diante do sistema mercantil, necessidade de vivenciar ações cotidianas, realizar rituais, como aponta Richard Schechner:

\begin{abstract}
Performances - de arte, rituais, ou da vida cotidiana - são "comportamentos restaurados", "comportamentos duas vezes experenciados", ações realizadas para as quais as pessoas treinam e ensaiam. (...) Toda e qualquer das atividades da vida humana pode ser estudada enquanto performance. Cada ação, desde a mais secundária até a mais complicada é feita de comportamentos duas vezes vivenciados. (...) As artes têm como assunto objetos de todos os lugares e de todas as espécies. Rituais e ações são não apenas gêneros de performances, mas também estão presentes em todas as situações enquanto qualidades, reações, ou modos (SCHECHNER, 2006, p. 28, 29, 31).
\end{abstract}

Segundo Glusberg (2016), com a apresentação da obra 18 Happenings em 6 Partes, no outono de 1959, Allan Kaprow (1927-2006) batizou uma nova tendência artística e essa obra de caráter espontâneo foi ensaiada por duas semanas, seguiu um roteiro minucioso quanto aos movimentos e tempo. Outros artistas adotaram outras denominações, como performance, por Oldenburg (nascido em 1929); evento, por Brecht (1898-1956); ação, por Joseph Beuys (1921-1986); dê-collage, por Wolf Vostell (19321998). 
Figura 12 - 18 Happenings em 6 Partes, de Allan Kaprow, 1959

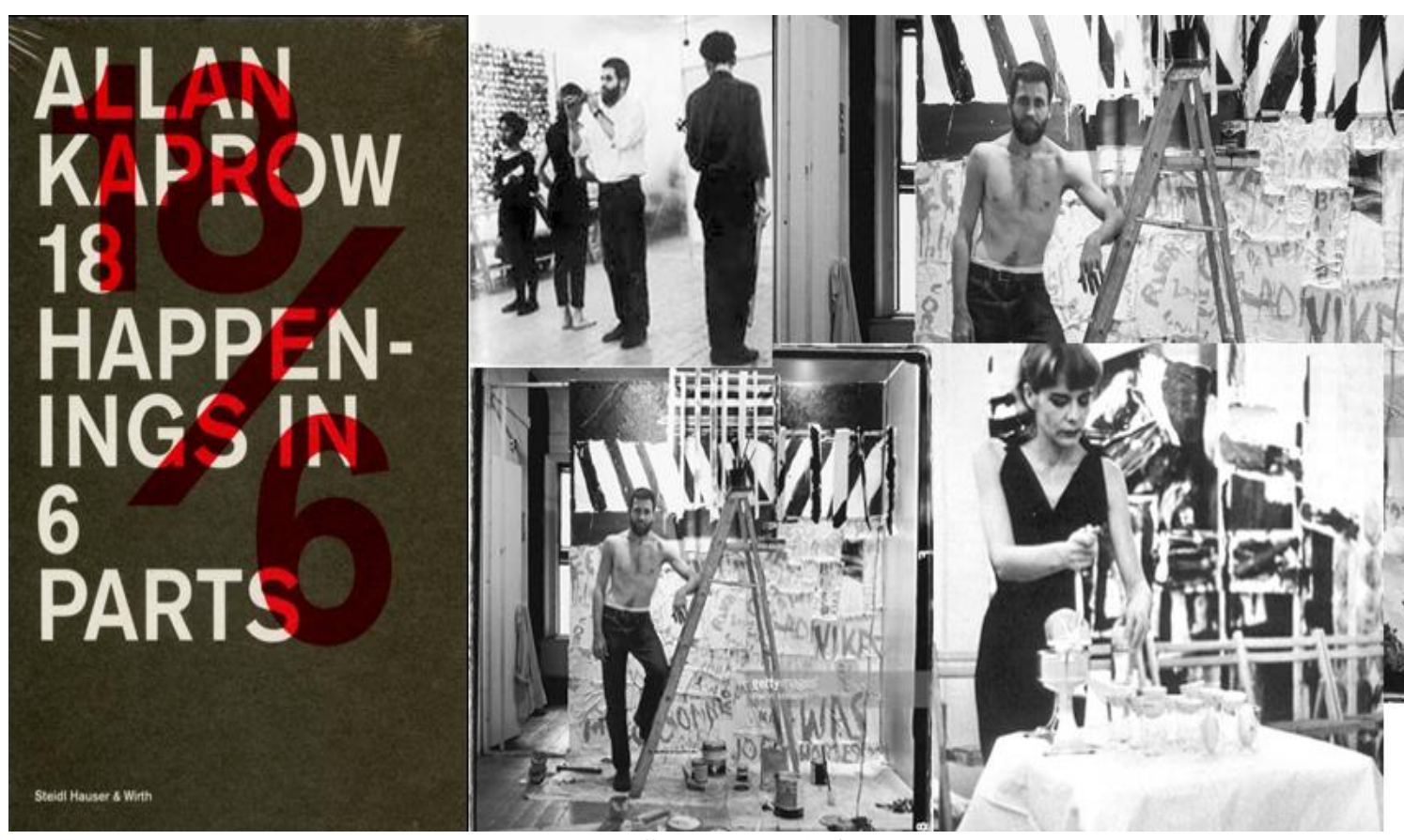

Fonte: Getty Images (s.d.)

http://www.gettyimages.com/photos/allan-kaprow---

artist?excludenudity=true $\&$ mediatype=photography \&phrase=allan\%20kaprow\%20-\%20artist\&sort=mostpopular

Outro aspecto importante na performance foi a influência da tendência moderna denominada arte conceitual, pela qual o objeto deixa de ser o protagonista da obra, deixando a ideia ou o processo ser a questão relevante, mesmo porque a importância no trabalho reside fundamentalmente na relação com o público e em um questionamento do natural com criações verdadeiras e espontâneas, operando transformações. Durante muito tempo, a arte utilizou vários materiais como suporte para transmitir sua mensagem, porém "a arte da performance é o resultado final de uma longa batalha para liberar as artes do ilusionismo e do artificialismo" (GLUSBERG, 2016, p. 46). Ou seja, em outras linguagens é comum a presença de materiais que, por vezes, determinam parcialmente o resultado do trabalho, já nas expressões que se valem do corpo enquanto matéria prima, como a relação do dramaturgo e coreógrafo, o produto final é representado por atores e bailarinos, quase como uma decantação, relação próxima à performance. 
Figura 13 - Como explicar quadros a uma lebre morta - Performance de Joseph Beuys, na Galerie Schmela, Düsseldorf, 26 novembro 1965

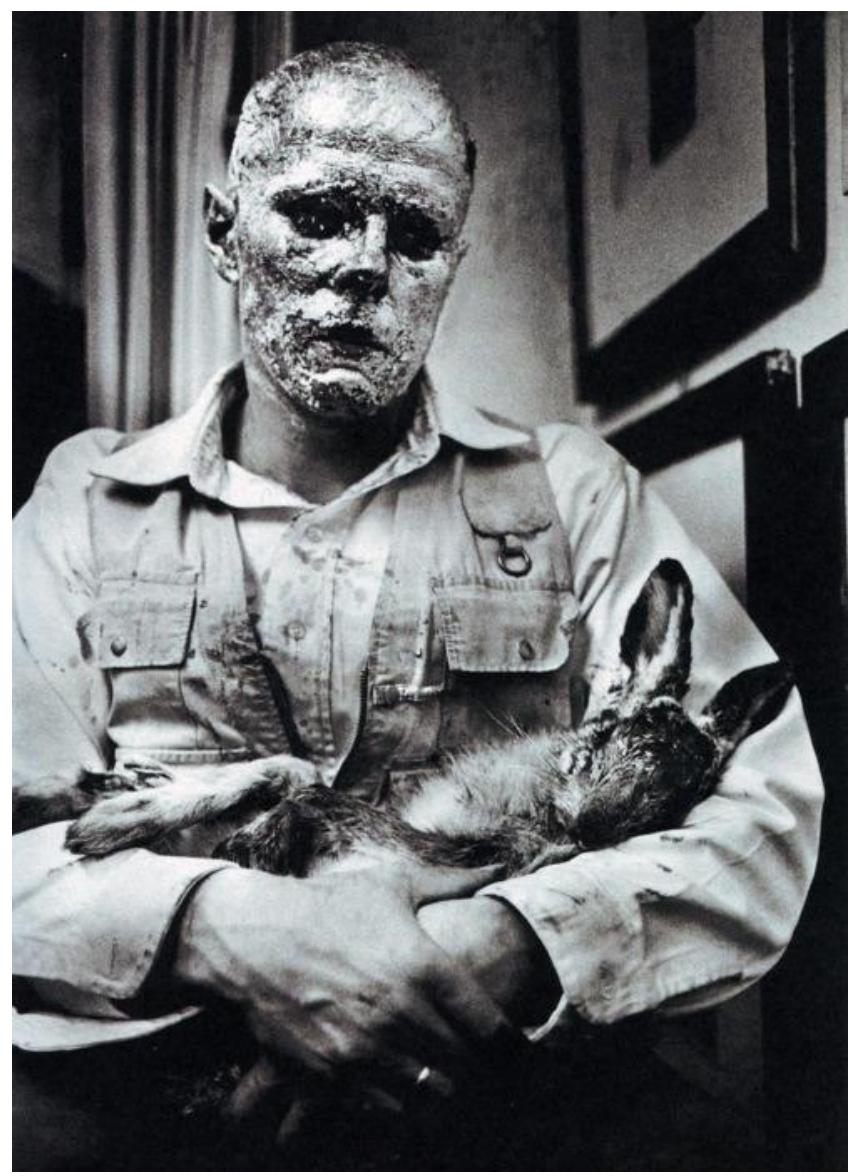

Fonte: Fonseca (2016)

http://www.artecapital.net/estado-da-arte-68-victor-pinto-da-fonseca-o-vazio-apocaliptico

Profissionais entrevistados, que atuam com a educação e ensino da performance em universidades defendem alguns pontos referentes a esse repertório expressivo. Cauê Alves (2016) acredita que a performance é uma linguagem híbrida, que traz a herança dos dadaístas, futuristas, do Cabaré Voltaire, como carrega questões como o escárnio, antiarte, a interdisciplinaridade, envolvendo muitos profissionais e disciplinas, e basicamente é um espaço aberto, e tentar defini-la de forma restrita pode estar fadada ao fracasso. Vale a pena destacar, que a Universidade Belas Artes de São Paulo completou 91 anos de existência em 2016, tem vocação para as artes contemporâneas e foi pioneira em introduzir a disciplina da performance no curso de artes visuais.

A performer e professora de performance Juliana Moraes (2016), que atua há 10 anos nas Belas Artes, argumenta alguns conceitos a respeito da performance. O termo surgiu a partir da década de 1970 e somente depois alguns teóricos começaram a estruturar sua história. Antes ela era entendida como parte integrante do que se chamava artes vivas (dança, teatro e circo), depois como desdobramento das artes visuais, e como Alves (2016) destaca, teve sua origem nas vanguardas, contudo, a nomenclatura 
"performance" foi consagrada pela artista Marina Abramović, antes dela outros artistas não apreciavam o termo. Segundo Moraes (2016), o curso dessa linguagem na Belas Artes foi introduzido por iniciativa dos professores, demanda pedagógica e foi muito difícil, principalmente pelo desconhecimento dos profissionais que sempre a apoiaram, e pela desinformação de alunos em outras áreas. No entanto, como a linguagem está no contexto e circuito das artes, sua incorporação no currículo se tornou essencial.

Em sua pesquisa de mestrado, Naira Ciotti (2017, p. 1), professora de performance desde 1994 na Universidade Federal do Rio Grande do Norte, tratava a linguagem dentro do conceito de arte híbrida ou multimídia, como era sustentado nos anos 1990, porém ela possuía duas referências, as artes visuais e as cênicas, com as quais ela trabalhava: "Então ela é uma antologia borrada como eu costumo falar, ela parte de um lugar, mas ela se manifesta em outro".

Por outro lado, outros especialistas entrevistados, com olhar de curadores e profissionais que atuam em instituições de arte possuem alguns pressupostos e entendimentos de performance. O Coordenador de Artes Visuais do SESC Pompeia, Alcimar Frazão (2016, p. 1), vê a performance como linguagem de fronteira, por construir sua trama, seu tecido narrativo, com outras linguagens, o "fato dela ser de fronteira, faz com que ela dê partida, se construir a partir dessa especulação dos limites", não utilizando somente o corpo, o que lhe atribuiu maior liberdade de ação. Para Frazão (2016, p. 1) no SESC, que em suas programações aborda arte contemporânea, algumas intervenções artísticas, por vezes, podem ser tratadas e compreendidas como performance, e essas fronteiras podem ser trabalhadas na instituição de forma fragmentada, no âmbito da programação, “embora haja um diálogo o tempo todo entre esse pensar as linguagens dentro da instituição, em algum momento essas linguagens vão ser separadas".

O diretor da Mostra "Verbo" de performance, Marcos Gallon (2016, p.1), se arrisca a dizer que a performance está diretamente ligada a seu tempo, que é uma crítica "que pode se materializar sobre um questionamento do estatuto do homem na atualidade, (...) é uma ação política, porque o corpo está sempre presente, porque o corpo está lá, desnudado", é uma linguagem híbrida, mas enfatiza que não se deve classificar como performance tudo o que não se sabe, ou não consegue conceitualizar, bem como não se deve tratar a performance como espaço, no qual é possível inserir qualquer coisa, pois ela tem sua personalidade. Como curador da Mostra Verbo, na Galeria Vermelho, ele é implacável, quanto às programações da mostra, que incluem artistas ligados à tradição de performance; contudo, a mostra absorve outros oriundos de outras linguagens, na qual a 
relação com o observador pode ser mais estreita, diferente do palco ou dos espaços estendidos.

Já a curadora da Pinacoteca de São Paulo e historiadora de arte, Fernanda Pitta (2016), considera que "performance é um gênero que pode ser entendido a partir de várias filiações", como o Dadaísmo, o Futurismo, a conexão com o teatro, a dança, mas são as neovanguardas nos anos 1960 que estabelecem o gênero e as várias concepções dessa linguagem, dependendo de cada trabalho e artista: "Mas o que me parece como questão fundadora é, justamente, esse entendimento do ato artístico como um ato performático, da ação como aquilo que, enfim, imobiliza o questionamento até sobre a noção de obra de arte, sobre a noção do fazer artístico" (PITTA, 2016, p. 1).

A perspectiva de artistas brasileiros, que possuem trabalhos em instituições de arte na cidade de São Paulo, e em outros espaços fora desse circuito, esclarecem os indicadores desse meio de expressão.

O performer Lorival Cuqinha (2017) utiliza o corpo, como meio de expressão para formatar e desformatar ideias por meio da intuição, quase como uma imposição da ideia que deseja expressar, mas ele não as intitula com uma terminologia única ou específica, já que passeia por várias linguagens, como vídeo, artes plásticas, teatro. Ele não tende ao clássico, mas, como aponta, está próximo da vertigem ou de algum tipo de mídia, e o que terceiros denominam performance são ideias que chegam e vazam, contudo, crê que a performance é uma linguagem híbrida, que necessita do corpo para se expressar, como a escultura nos dias atuais.

Performance, por ela ser no meu caso uma imposição da ideia, a ideia como no caso de um policial, (...) foi vendido ao MAM, que na verdade ele é um policial dentro de uma exposição de arte (...). O que me interessava é a fricção entre os ambientes, que não passam muito pela rua, os ambientes de arte que não têm a rua, no seu seio de convivência muito forte. A polícia não é uma noção de segurança para a gente, e essa fricção do ambiente em que a polícia geralmente não está tanto como público, ou tanto como até às vezes Estado opressor ou Estado vigilante presente. Colocar aquilo ali, era o que me interessava e como eu ia colocar aquele estado vigilante dentro de um ambiente artístico. (...) Ele era a personificação da vigilância do Estado (CUQUINHA, 2017, p. 1).

Cuquinha (2017) lembra com apreço o artista Tunga, que denominava suas ações não como performance, mas como "instaurações". Para Cuquinha, a terminologia também é um meio de comunicação e ele explica que quando contrata alguém para atuar em seus trabalhos utiliza a denominação performance, mas refletindo e conversando com outras artistas, ele acredita que essa denominação pode ser flexibilizada, pois o termo carrega significado e a obra em si não traz legenda. Por isso, em algumas vezes, Cuquinha se aproxima de Tunga e de seu conceito. 
Cuquinha (2017) também lembra de Laura Lima, que trabalha com carne, como ela própria qualifica e não performance. Lima utiliza homem carne, mulher carne e afirma: não é corpo, não é carne. Segundo Cuquinha, Lima é um empurrão do conceito de performance.

Laura Lima (2017) ratifica a observação de seu colega Cuquinha, pois não confere ao seu trabalho a definição de performance. Com o passar do tempo, Lima foi entendendo a performance, apesar dessa expressão ainda ser um mistério, pois se relaciona com várias linguagens, e por ser seu ponto mais fascinante. Laura Lima afirma nunca ter intitulado sua atuação com esse glossário [termo que a artista utiliza], mas tem consciência de que foi o seu trabalho, a primeira aquisição em museu brasileiro no caso a obra "Quadris de homem = carne / mulher = carne", de 1995, adquirida em 2000, pelo Museu de Arte Moderna de São Paulo.

A artista Laura Lima utilizava animais e pessoas, seres vivos, como matéria prima. Essa abordagem utilizada pela instituição causou estranhamento à artista, porque ela não via sua obra como performance. Mas, ao longo do tempo, seu conceito foi se expandindo, mesmo porque o trabalho já tinha sido categorizado. Outra questão latente para a artista é que vivemos em um momento de catalogações, e os museus fazem uso dessa ordem, mesmo sendo uma forma obtusa de enxergar obras de arte, afinal, um artista pode ver seu trabalho de forma distinta da instituição. Laura entende, no entanto, a importância da inclusão de seu trabalho como performance no MAM-SP pela abertura histórica que representa.

Eu entendo que o que o meu trabalho serviu a um certo momento. Foi para falar também de um certo ativismo de abertura, que as instituições estavam colocando, "prestem bem atenção, nós não colecionamos só a questão do objeto, nós podemos lidar com uma obra que se coloca assim como tal, que tem um caráter performativo (LIMA, 2017, p. 1).

Lima reconhece que performance se amplia tanto que ela "arranha outros trabalhos" ou outras linguagens, mas o rótulo também pode restringir parte do fenômeno que a obra possui. Segundo Lima (2017), as obras de arte são restauradas, e isso nunca é uma intervenção definitiva por incorrer em apagar vestígios originais e pela própria evolução da técnica de restauração. Assim, a catalogação deveria ponderar essa dinâmica, e repensar o caminho para as nomenclaturas.

Para o performer Maurício Ianês (2017) definir performance pode empobrecer a ação, porque ela nasce do fato de se desmontar barreiras e advém de muitos cruzamentos artísticos: das artes cênicas, com movimentos de vanguarda, que objetivavam romper fronteiras, apresentar o novo, lutar contra o avanço em tratar a obra como mercadoria. A 
performance pode ser entendida como linguagem híbrida, mas essa abordagem pode criar restrições à linguagem, que sofre variações conforme o contexto. $\mathrm{O}$ que é fundamental para Ianês (2017, p. 1) é a "desidentificação do que para um processo de identificação, de definição do que é a performance”. A terminologia utilizada normalmente não está relacionada às artes plásticas, tampouco com as ações nos espaços institucionais, ela é flexível. Os termos são muitos: fotoperformance, videoperformance, existe também palestras, diálogos, ações cotidianas, multimídias, entre outras definições denominadas performances. Segundo Ianês (2017), muitos artistas aplicam esses termos para explicar suas ações, porém, cada obra é única, com suas características distintas e se atualiza a cada nova ação.

São muitos os indícios de que a performance teve uma jornada complexa e foram muitos artistas que deixaram registradas suas ações, quase sempre polêmicas, mas embutidas de significados e provocações, que por vezes o público teve dificuldades em compreender. Contudo, não se pode afastar essa expressão tão visceral, na qual o público é convidado a participar com alguma ação ou a refletir intensamente, talvez por isso essa linguagem, apesar de sua imaterialidade, vem adentrando as instituições e eventos de arte.

\subsection{CONSIDERAÇÕES DA LINGUAGEM PERFORMANCE: A VISÃO DA ARTE CONTEMPORÂNEA}

O que se pode considerar por "arte”, o que possui dimensão estética está em constante movimento, mesmo porque definir o que é arte depende de muitas variantes, como o contexto, circunstância histórica e convenções locais. Ao mesmo tempo, o "fazer arte" está diretamente ligado ao ato de avaliação, por exemplo, objetos de ritos de determinada cultura ou período histórico podem se tornar obras de arte em outros momentos (SCHECHNER, 2016). Os paradigmas ao longo da história vão se transformando e, em meados do século XIX questões sociais, políticas e econômicas, desdobramentos da Revolução Industrial pautaram a vida social e estética sobremaneira.

O surgimento de máquinas começou a substituir algumas atividades até então executadas somente pelo homem, como a fotografia e, posteriormente o cinema, e mudaram o comportamento humano, ao mesmo tempo alteraram a relação entre os artistas e a indústria. $\mathrm{O}$ aparecimento da fotografia foi um exemplo evidente, pois registrava a imagem com grande precisão e otimizava o tempo quanto à execução, influenciandoprincipalmente os pintores de ofício. Com isso, passou-se a questionar o 
conceito de arte, como atividade espiritual e se estabeleceu a partir daí dois tipos de imagens: pictográfica e fotográfica (ARGAN, 2013). Novos suportes e materiais entraram no cenário artístico, e temas do cotidiano que envolviam a relação dos indivíduos ou que se relacionasse diretamente à sociedade pautaram cenários com a mesma velocidade das indústrias.

O universo das artes contemporâneas abarca inúmeras possibilidades de expressão, seja pelos materiais ou suportes, pelo conceito e até mesmo no campo virtual, que parece estar vivo em diversas esferas. O olhar dos artistas, críticos, marchands, galeristas, colecionadores e apreciadores de arte não deve estar sujeito a julgamento intelectual ou moral, mas deve se comunicar sem fronteiras. O mesmo pode acontecer com o gesto, o corpo do artista e a resposta direta com o ambiente, quando o artista reivindica o status, o direito do corpo como forma de expressão e de manifestação (CAUQUELIN, 2005). A performance pertence a esse universo das artes contemporâneas podendo ser considerada ícone de visibilidade no século XX ao lado de outras manifestações, sejam elas conceituais, figurativas, abstratas, espontâneas, associadas ao gesto, ao corpo, à ação, e sobretudo é tradução do fazer artístico do homem contemporâneo.

Não menos importante é a compreensão da trajetória da arte e seus desdobramentos, principalmente no século XX, período em que a performance apresenta sinais efetivos de sua presença no universo artístico. Durante muitos séculos a arte esteve ligada ao naturalismo, representando basicamente a natureza, principalmente em quadros e esculturas. Porém, em meados do século XIX, rupturas apontavam para o advento da descoberta da eletricidade e o aparecimento da fotografia, já tratados neste capítulo. A expressão artística começa uma trajetória ligada diretamente às máquinas e não mais necessariamente a habilidade e destreza do artesão, que antes era o único responsável pela execução dos trabalhos artísticos (ARGAN, 1993).

Arte, tecnologia, ciência e relação com utilização de novos materiais no universo das artes abriram espaços às outras linguagens e formas de ver o mundo. Esse novo olhar abre espaços para manifestações até então impensáveis nesse redemoinho de ideias, manifestações, rupturas e lacunas. É aí que a performance começa a dar sinais e a se instalar no palco das apresentações e manifestações artísticas.

Mais do que constatar lacunas na trajetória da arte contemporânea e seus desdobramentos, é importante traçar caminhos para o entendimento de conceitos de arte desde meados do século XX, no sentido de apreender expressões essenciais da sociedade em todas as linguagens artísticas (GULLAR, 1993), mesmo porque o entendimento de 
arte está consonante a questões do seu período histórico, político e social. Se no passado a arte esteve ligada ao mecenato, à nobreza e à igreja, que solicitavam e pagavam os artistas por suas encomendas e atividades artísticas, no século XIX com a ascensão da classe burguesa e o regime industrial começaram a se estabelecer relações de consumo, nas quais a arte está inserida. Essas relações comerciais de arte permanecem e se ampliam nos séculos XX e XXI, e a obra passa a ser tratada como produto.

No período conhecido como arte moderna, artistas reivindicam espaços de exibição de seus trabalhos afastados da hegemonia da Academia, ligados ao Salão de Paris $^{20}$, que até então controlava a vida e a carreira dos artistas de forma centralizada. $\mathrm{O}$ desdobramento dessas questões foi o Salão dos Independentes, anteriormente denominado Salon des Refusés, em Paris (1863), que ampliou o alcance dos profissionais de arte, mas a força emblemática de instituição oficial continuou a ser sinônimo de seriedade, principalmente nas relações de compra e venda de objetos de arte, dando início ao mercado independente, fortalecendo a presença de profissionais como o marchand e o crítico, bem como o aparecimento de copiosos grupos independentes.

A sociedade contemporânea e suas manifestações são ampliadas pela comunicação, suas novas plataformas e efeitos, principalmente os tecnológicos que abarcam a ideologia da igualdade de informação, fundamentalmente por ser apresentada em tempo real e pela chamada rede, na qual a informação circula e permite a conexão. A palavra de ordem do momento é "interação", a outra qualidade ao seu funcionamento é o papel da linguagem "e o uso cada vez mais generalizado delas alteram nossa visão da realidade. Constroem, pouco a pouco, outro mundo" (CAUQUELIN, 2005, p. 64).

Nesse contexto as linguagens se agregam, dialogam entre si, e em alguns casos pintura e escultura se fundem. Artistas passam a criar com sucatas, com materiais industrializados como fez Marcel Duchamp (1887-1968) com seus famosos readymades $^{21}$ e novas ordens vão sendo estabelecidas. Em outros momentos, há quebra total de regras, introduzindo provocações e o acaso pode apontar origens da performance ao lado

\footnotetext{
${ }^{20}$ O Salão Oficial fundado em 1667, em Paris, se caracterizou por exibir obras de arte, em especial pinturas, dos membros da Academia Real de Pintura e Escultura. "O salão era uma reminiscência do Estado absolutista no campo da arte, mas já então funcionava como uma espécie de Bolsa que atribuía cotações às obras de arte: uma instituição antiquada servindo às novas relações econômicas. Mas servindo mal, pois introduziam na avaliação das obras os preconceitos estéticos e morais do ancien regime. (...) mas não se ignorava a importância comercial que tinha para os novos artistas uma distinção obtida no Salão. Por outro lado, ter seus trabalhos ignorados pelo júri significava não conseguir mercado para suas obras" (GULLAR, 1993, p. 90).

${ }^{21}$ Duchamp inventou o termo "para descrever os objetos fabricados em série que ele escolhia, comprava e, a seguir, designava como obra de arte. O primeiro foi Roda de bicicleta (1913), uma roda de bicicleta sobre um banco; o mais escandaloso, Fonte (1917), era um urinol masculino assinado "R.Mutt". Com os ready mades, Duchamp pedia que o observador pensasse sobre o que definia a singularidade da obra de arte em meio à multiplicidade de todos os outros objetos" (ARCHER, 2013, p. 3).
} 
de movimentos vanguardistas, com pensamentos de antiarte, busca de provocações e desafios no sentido de romper com a arte tradicional e indicar novas formas de expressões artísticas.

A narrativa da performance se opõe às artes tradicionais, aquelas que utilizam o corpo, como a dança e o teatro, mesmo que interpretando papéis consagrados, como os grandes clássicos: Shakespeare, ou Diaguilev, oferecem aos artistas oportunidade de interpretar trabalhos famosos, mas com espaços de inovação a cada espetáculo. Contudo, uma das características dessas ações talvez esteja no público, que normalmente sabe o que irá ver e vivenciar. Com a performance, no entanto, acontece algo de misterioso, nunca se sabe como irá se desenrolar, mesmo quando o performer, o artista, minuciosamente estrutura seu trabalho, porque o diálogo e interação com seu público dará o tom da execução.

Nessas circunstâncias, a recepção, o consumo dessa arte, criam um paradoxo, uma manifestação que confronta o institucional, que tem na ruptura e transgressão dos códigos vigentes seu mote, em aderência às manifestações artísticas. Essas questões podem desestabilizar convenções cristalizadas, dificultando ao espectador o entendimento que, por vezes despreparado, pode gerar reações adversas como repulsa, indiferença, mesmo porque, a arte não tem discurso linear pressupondo sua interpretação, e pode variar conforme o arcabouço cultural de quem a recebe (GLUSBERG, 2016).

Em outros termos, fica imbricada a assertiva de uma conexão circular entre o performer e o público, quase como em uma relação entre o natural e o cultural; e até mesmo se pensarmos nas questões ritualísticas, que algumas performances desenvolvem, criam-se aí polos entre o profano e o sagrado.

Anne Cauquelin (2005, p. 161) aborda essas questões e amplia o campo de atuação das artes denominadas por contemporâneas, seus significados e sua fruição na sociedade:

\footnotetext{
A arte contemporânea por muitas vezes é mal apreendida pelo público, que se perde em meio aos diferentes tipos de atividade artística mas é, contudo incitado a considerá-la um elemento indispensável à sua integração na sociedade atual. Aonde quer que se vá, não importa o que se faça para escapar, a arte está presente em toda parte, em todos os lugares e em todos os ramos de atividade.
}

A performance, como outras linguagens contemporâneas, surge carregando questionamentos sobre a arte e as instituições, seus desdobramentos no momento em que a ação acontece, bem como valores, meio ambiente, poder, identidade cultural etc. Afinal, o mercado e a lógica das galerias comerciais representavam no universo capitalista um recorte da produção artística bastante significativa. Alguns artistas dependiam desses 
órgãos para desenvolverem seus trabalhos, por questões econômicas, mas sofriam o risco de se tornarem reféns dessa ordem. Nesse contexto, "a arte pública desenvolveu-se, em parte, como resultado de um desejo de contornar esse dilema" (ARCHER, 2012, p. 144). Outros espaços foram apontados como possibilidade de manifestações artísticas, como bibliotecas, lojas, ruas, enfim, a arte pública encontra meios de exposição, aquém das galerias e museus.

Outras linguagens como instalação, grafite, arte pública, ao lado da performance no campo das artes contemporâneas apresentam complicações quanto ao consumo, diferente das artes tradicionais, como quadros e pinturas, que o consumidor compra e leva para onde quiser. Essas obras precisam encontrar novos caminhos e nesse contexto essas linguagens não se descolam das questões econômicas, por vezes necessita de editais e leis de incentivos, que por meio de patrocínio público, ratificam a ideia de que arte é uma necessidade da sociedade moderna como argumentou Archer (2012, p. 146): “a arte sem dúvida, não era um luxo, mas algo que qualquer sociedade evoluída que se prezasse deveria ter como marca de sua condição de civilizada". Mas essa trajetória também induziu várias instituições a se abrirem para esse novo contexto, agregando em seus espaços trabalhos com propostas cada vez mais conceituais, que dialogam com seu público.

A linguagem de performances, assim como as das artes contemporâneas, não pactua em traduzir conteúdos para o apreciador, mesmo que não seja clara, mas é habitada por significados, experiências e texturas. O sentido não está fora da representação, em questões exteriores, mas na sua abordagem interna, subjetiva, repleta de metáforas, que a ressignificam singularmente. O importante para os artistas e o público é o ato de elaborar, encenar e interagir com a arte, necessidades fundamentais do homem. 


\section{CAPÍTULO II - REGISTROS DE PERFORMANCE}

O capítulo pretende explorar os registros da linguagem que normalmente são encontrados em acervos e coleções tentando arquivar a imaterialidade dessa linguagem artística que acontece no ato da ação ou da encenação. Apenas deixa como legado fotos, vídeo, vestígios, documentos, busca-se compreendê-los, bem como os procedimentos e tratativas entre artistas e instituições, no sentido de garantir que esses materiais permitam a fruição da performance nas coleções e acervos.

Muitos são os registros de performance que constituem uma coleção e/ou acervo: documentos descritivos, resíduos, fotos e vídeos, sendo esse último, em alguns casos, a própria performance na plataforma digital.

\subsection{DOCUMENTOS E CERTIFICADOS DE PERFORMANCES}

A performance para fazer parte de uma coleção ou um acervo, normalmente utiliza duas possibilidades: o registro documental, com descrição e orientações que descreve e informa como aconteceu a performance e indica as possibilidades de reencenação ou reperformance da obra; e o certificado garante os direitos autorais do comprador, como proprietário.

\footnotetext{
Quando a Laura Lima vendeu a performance dela para o MAM, ela vendeu uma série de instruções em papel, então são coisas diferentes, uma coisa é o MAM filmar a performance da Laura Lima sendo feita lá no MAM, (...) mas para que o MAM possa reencenar esta performance quando lhe "der na telha", ele precisou comprar a performance, e para comprar, não comprou o vídeo, comprou uma série de instruções, e elas vêm em papel. Ou seja, a Laura Lima escreveu em um papel: Esta performance consiste em dois [atores] performancers..., ela diz a idade, às vezes até o tipo físico que precisa caber no figurino, ela diz onde e como a pessoa tem que se mover, ela pode incluir também um vídeo ou também outro registro para dar a ideia de como se [deve] fazer (MORAES, 2016, p. 5).
}

Da mesma forma que um visitante que não conseguiu ver uma obra de arte no museu o faz por meio de publicações, pode-se fazer um paralelo com a performance. $\mathrm{O}$ público que não esteve na apresentação de uma ação pode apreciá-la por meio de uma foto e/ou vídeo devido à verossimilhança, como opção de pesquisa ou entretenimento, apesar dos questionamentos que esses formatos possam carregar em suas significações.

Há sim como documentar uma performance, que vai se transformar em um objeto, a algo que pode eventualmente voltar para galeria novamente como outra coisa que não é a performance, e que também não é um documento 

ser retomada, essa é a beleza da performance (GALLON, 2016, p.10).

Quando um colecionador ou um museu compra uma performance, além do documento descritivo que normalmente detalha a encenação, biótipo, objetos e espaço cênico e outros aspectos que o artista acredita ser relevante, ele fica com os direitos de propriedade da obra. Caso venha a ocorrer uma reencenação dessa perfomance é necessário negociar com o colecionador, pois o artista abre mão do direito de posse, mas a obra sempre será de sua autoria, como acontece com qualquer objeto de arte.

Certificar uma obra, cujo objeto é o corpo de uma pessoa, não é uma novidade. Piero Manzoni, em 1961, eliminou a tela em suas criações, isso ficou evidente com "Escultura Viva", na qual ele assinava parte dos corpos, resultando em um "certificado de autenticidade", com a epígrafe:

Este documento certifica que $\mathrm{X}$ foi assinado(a) por minha própria mão, podendo portanto, a partir desta data, ser considerado(a) como uma obra de arte autêntica e verdadeira (...) o certificado vinha com um selo colorido, indicando a área designada da obra de arte: o vermelho indicava que a pessoa era uma obra de arte total (...); o amarelo, que só parte do corpo assinada podia ser considerada como arte; o verde impunha uma condição e limitação à atitude ou pose em questão (dormir, cantar, beber, falar, etc.); e a cor de malva tinha a mesma função do amarelo, excetuando-se o fato de que tinha sido obtida mediante pagamento. (GOLDBERG, 2015, p. 122).

Figura 14 - Performance Esculturas Vivas, de Piero Manzoni, 1961. Mostra o Corpo expandido

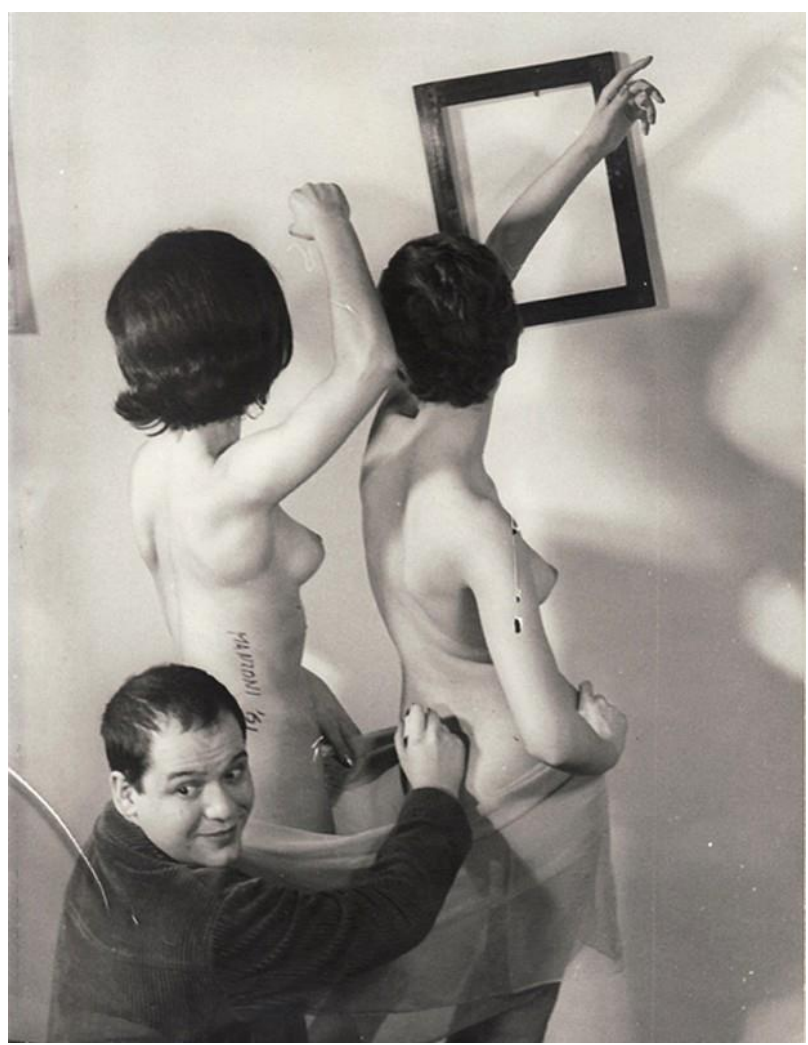

Foto: Giuseppi Belloni. Galeria Jaqueline Martins, 2013. 
Um exemplo de instrução para se executar uma ação corporal aconteceu com Oskar Schlemmer em "Dança de Gestos" (1926-27). Ele criou um sistema gráfico de notações, um diagrama dos movimentos dos bailarinos, em consonância com personagens vestidos nas cores primárias, revelando a plasticidade do corpo humano. As ações que se valem do corpo como ferramenta e objeto de arte sempre se utilizaram de partituras, esquemas, roteiros e indicações para a encenação a ser executada, bem como a utilização de objetos, cenários e figurino, essas práticas acontecem no teatro, na dança, na pantomima, nas manifestações circenses, que também contam com preparo físico e técnico, a performance por também utilizar o corpo como elemento de expressão, quando se torna obra de um acervo, carrega com ela documentos com essas orientações.

\section{Figura 15 - Diagrama para "Dança de Gestos", $1926^{22}$ Ao lado cena de Dança de Gestos, com Schlemmer, Siedhoff e Kaminsky}

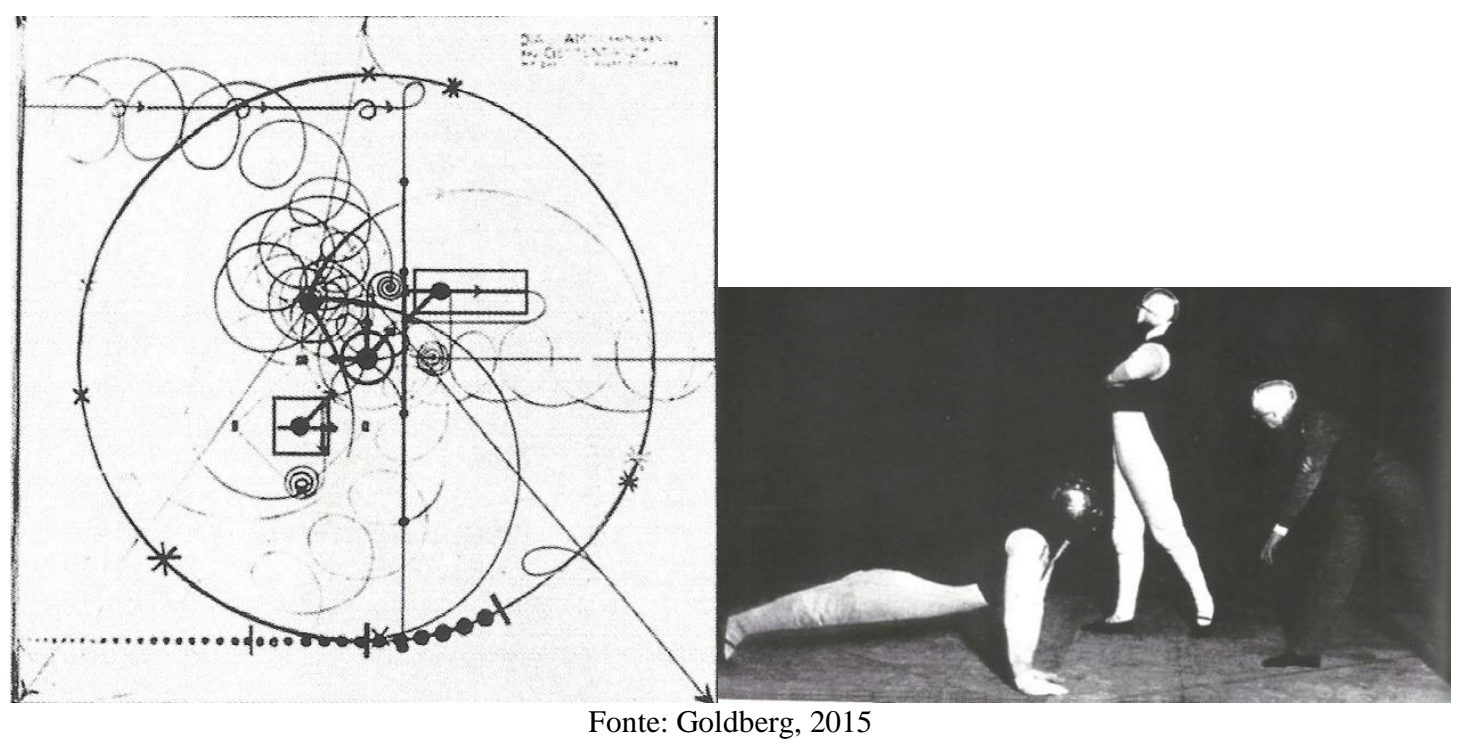

Outra demonstração da importância dessas orientações na performance, apesar de seu aspecto livre e do uso da improvisação e interferências locais, foi a publicação, em 1976, do livro "Os elementos da arte performática", com textos de teoria e prática dessa linguagem, oriundo da companhia de performance Ting Theatre of Mistakes, que iniciou o ano de 1974 com uma oficina da expressão artística em parceria com artistas norteamericanos (GOLDBERG, 2015).

O mundo não é inerte, está sempre em transformação, e com a performance não poderia ser diferente, a cada reencenação, ela terá outra leitura, uma pintura, independentemente de sua técnica, autoria ou época. Cada curadoria estabelece relações

\footnotetext{
${ }^{22}$ Diagrama com palco aberto em ambas as extremidades. O complexo sistema de notação de Schlemmer era usado para planejar e registrar os movimentos reais de cada performance.
} 
com o espaço, com a proposta da exposição, da curadoria e sempre carregará o passado e o presente em um exercício cíclico, com múltiplos sentidos que a arte permite, tal sua grandeza.

A documentação será referência, e apesar das semelhanças e incongruências, amadurecerá e relacionará com o público a suas nuanças e reações. "A ideia que a performance seja uma coisa pronta e acabada, ou que a arte seja isso, ela é muito limitada, está sempre em processo, sempre se transformando, e a performance é obviamente é o lugar da ação, então isso é mais evidente” (ALVES, 2016, p. 4).

Algumas performances que foram tombadas e estão em reservas técnicas possuem descritivo técnico e quando a execução não depende do artista que a criou, ou seja, utiliza outros corpos para performar. Essas ações dependem da direção e indicações do artista. Essa prática performática, quando não precisa da presença física do artista, facilita sua institucionalização. Apesar da origem da performance ser anti-institucional, com o tempo entrou nos acervos dos museus, mesmo porque os artistas desejam estar presentes nessas instituições, no circuito comercial (ALVES, 2016). Os documentos que os museus detêm quando adquirem uma obra dessa natureza garantem a inserção dessas expressões artísticas e das suas mais diversas peculiaridades no contexto institucional, mas, acima de tudo, sua difusão e visibilidade junto aos seus visitantes.

Alcimar Frazão (2016, p. 8), um dos responsáveis pela exposição “Terra Comuna” de Marina Abramović, acredita que os registros de performance são quase "uma partitura corporal e conceitual da performance". Para Frazão (2016), Marina defende que a performance não seja fechada, criando condições para que outros artistas possam ressignificar essas ações, com o cuidado de informar o artista criador e evidentemente creditar a autoria. Segundo Frazão (2016), o teatro, que também trabalha com a matéria prima "corpo", tem como guia o texto como base do trabalho, mas uma peça como Hamlet, quantas vezes for executada, tantas vezes trará algo novo, apesar do código peculiar de Hamlet estar no DNA da ação, pois um conjunto de artistas completamente diferentes vivenciará e atuará a peça colocando suas marcas pessoais.

O teatro possui um texto guia e a dramaturgia que possibilita a multiplicação, "embora ele nunca seja de verdade multiplicável”, o mesmo acontece com a performance, “com a complexidade que você não tem o guia, não tem o texto, (...) você tem lá um corpo conceitual que foi codificado pelo artista, pelo artista criador primeiro e que outros artistas interpretaram" (FRAZÃO, 2016, p. 9).

A dança também utiliza uma espécie de partitura, mas a performance tem que lidar com essa questão, para transformar a ação em acervo. De acordo com Frazão (2016, 
p. 7), é um segundo trabalho, não a performance em si, “que acontece no tempo e espaço, com data, com período, (...) esta ação cênica pode ser codificada e reinterpretada por outros performers", mas sempre que reperformada deve lidar com as devidas autorizações, seja do artista ou do proprietário.

É bastante comum que galerias de arte apresentem performances em suas programações e reconheçam o status que essa linguagem reverte para a instituição. Elas também comercializam essas ações para colecionadores. A Galeria Vermelho, em São Paulo, tem em seu calendário anual a "Mostra Verbo" de performance, desde 2005, e seu diretor Marcos Gallon (2016) é categórico ao afirmar que a Vermelho não possui acervo de performance, mas um "reservatório de ações", registros fotográficos e videográficos de todas as ações que passaram pela galeria, material essencial para a realização de uma publicação da Verbo, um catálogo, com registros e documentos acerca das ações da mostra.

Um aspecto estrutural se iniciou a partir da Verbo em 2008, com o seminário "Verbo Conjugado", para se pensar e discutir conceitualmente a linguagem, acerca de questões atuais da performance, tais como: guardar e administrar acervos de performance.

Por outro lado, Gallon (2016) observou que as instituições ainda não entendem de forma plena a performance, criando uma certa resistência em integrar obras dessa natureza em seus acervos, devido ao caráter imaterial que apresentam. Mesmo para as pessoas que entendem de arte conceitual, se faz necessário criar condições de preservação, para assegurar a permanência da obra; outra questão é compreender como se mantém acervos imateriais. Nesse contexto, as instituições tiveram que se apropriar de aparatos para receber essas obras; em contrapartida os artistas tiveram que assimilar essa lógica, porque as negociações acontecem em diálogo com os artistas que apontam os aspectos, as características e as condições necessárias para que a ação ser reencenada, ele é o responsável pelo material e pelos documentos que integram a performance, e esse substrato que o museu irá guardar. São muitos detalhamentos específicos por se tratar de uma ação no tempo-espaço, ficando difícil definir um formato, porque não é um objeto de arte, nem só uma anotação sobre a performance.

Frazão (2016) destaca que algumas performances só poderão ser reencenadas enquanto o artista estiver vivo, levando a instituição a considerar que, após a morte do artista a obra desaparecerá, restando apenas os registros. Outras performances poderão ser reencenadas por terceiros e há muitos casos distintos que permeiam essa demanda. Artistas, museus, galerias e feiras de arte têm uma longa jornada e responsabilidade para garantir que essa expressão artística se faça presente oficialmente e acessível ao público. 
Outra demanda apontada é o acervo material, o que fica, quando a coleção é de performance?

Sobretudo Gallon (2016, p. 6) adverte que alguns artistas proíbem o registro de suas ações: "é um campo que tem esta beleza, que é o indefinível, que não existe um formato padronizado de recepção".

A vivência profissional leva Naira Ciotti (2016) a pensar os registros de performance como projeto, da mesma forma que acontece tecnicamente com instalações. O projeto é o documento que além das descrições controla a quantidade de vezes que ela acontecerá, e por quem será feita ou até mesmo se essas indicações não devem ocorrer. Quando a obra se torna acervo tudo isso se transforma em documento, mas também existe margem para a negociação. Essa é a lógica do pensamento e de um projeto de arte conceitual. Ciotti ainda lembra dos "registros críticos", os textos, livros referentes à performance, que apesar de poucos, estão em crescimento no Brasil, graças aos pesquisadores interessados no tema, como as referências teóricas que ajudaram a embasar essa dissertação.

Existem também os "registros genéticos, os documentos genéticos", materiais dos próprios performers:

Eu lembro um pouco do Artur Barrio, Paulo Bruscky, que deixam assim indicações, cadernos, arquivos genéticos de como aquilo foi produzido e isso pode ser incorporado aos acervos como documentos de performers, (...) as performances podem ser documentadas, esse documento ele tem uma performatividade também (...). Aí já é um pouco outra questão. (CIOTTI, 2017, p. 4)

Apesar de Ciotti (2017) afirmar não ser especialista nas técnicas de catalogação, ela acredita na documentação referente a produção do artista, bem como na recepção do público, afinal, "o público não é passivo" e a catalogação deveria tentar responder a essa participação, como documento, um registro dessa ação.

Com a percepção de curadora, Fernanda Pitta (2016) pontua que a performance impõe desafios quanto à incorporação nos acervos, mas a natureza se assemelha a outras linguagens, no que se refere à catalogação para o estudo e conservação, mesmo porque eles foram tradicionalmente organizados com base nos suportes e na linguagem.

E cada vez mais quando a gente vai caminhando na arte moderna, na arte contemporânea, a gente vê que esse tipo de catalogação, ela é restritiva, ela não funciona para muitos casos. Então, muitos trabalhos que usam um suporte de pintura tem uma relação com a fotografia, por exemplo, ou são (gestuais) e se relacionam com a escultura, mas tem mais um caráter instalativo (PITTA, 2016, p. 2).

De alguma forma, é necessário reconhecer que as produções e os debates artísticos vêm abalando as categorizações artísticas. No campo da performance isso fica claro, os 
registros e sua incorporação no acervo abrem espaços para várias pesquisas e reflexões, são celeiros propícios para se pensar os desafios da preservação dessa linguagem, especialmente porque cada proposição é de caráter único.

A Pinacoteca de São Paulo, por exemplo, introduziu em seu acervo a performance de Maurício Ianês intitulada “O Nome”. Por ser a primeira nessa categoria na instituição, e o cadastro de dados não ter essa categoria, o museu a cadastrou como instalação. Pitta (2016) destaca que essa obra para ser reperformada deve seguir um roteiro, uma partitura com instruções claras (Anexo II), oportunizando sua execução repetidas vezes, respeitando os requisitos que constam nos documentos, além da anuência do artista no processo, já que ele a criou para terceiros a executarem.

Figura 16 - "O Nome”, Projeto Octógono, Pinacoteca do Estado, São Paulo (2013)

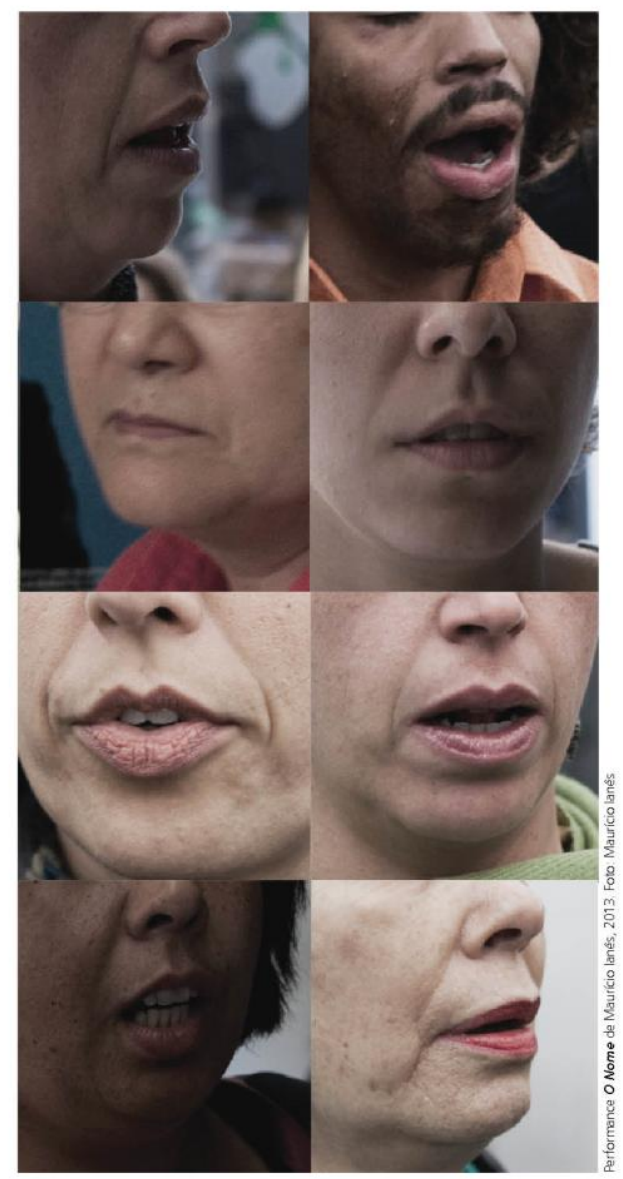

Ministério da Cultura

Governo do Estado de São Paulo

Secretaria da Cultura

Pinacoteca do Estado de São Paulo

convidam para a performance

\section{O Nome} de Maurício lanês

com a participação de colaboradores da Pinacoteca

Projeto Octógono Arte Contemporânea

28 de novembro de 2013 (quinta-feira), às 19h

Apresentações

dias 29 e 30 de novembro, às $12 \mathrm{~h}$

Censura Livre L

PINACOTECA DO ESTADO dE SÃo PAULO

Praça de Luz, 2 迥 Estaçăo Luz do Metró

cep 01120-010 - São Paulo - SP - Fone 3324.1000

Associação Pinacoteca Arte e Cultura - APAC

www. pinacoteca.org.br

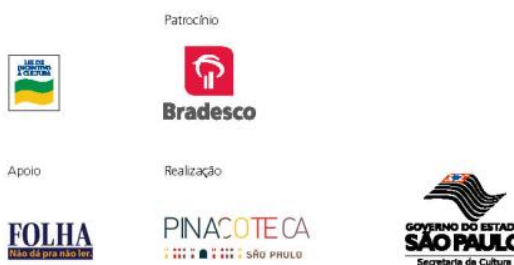

miscisis

Fonte: http://visual-artv.blogspot.com.br/2013/11/pinacoteca-o-nome-de-mauricio-ianes.html

Outra observação da curadora Pitta (2016) é que essa obra terá vida indeterminada, para o além-túmulo do artista e da equipe que recebeu a obra, contudo é importante ressaltar que cada caso merece uma discussão ou modos operantis de incorporação nos museus. A obra foi incorporada por meio de um dossiê, conforme sugestão de Ianês. 
Dossiê com instruções bem claras, como se fosse uma espécie de partitura mesmo, com orientações bem precisas sobre a forma de reencenação ou reapresentação ou reperformance da performance (...) E também o Maurício selecionou algumas imagens que ele tinha da performance apresentada aqui na Pinacoteca no ano de 2013. (...) O Maurício deixou bem claro, que isso não é a obra, isso são documentos, que permitem a execução da obra, mas que isso se um dia, por algum motivo (...) for apresentado ao público, tem que ser apresentado com muito cuidado e com a indicação de que aquilo são documentos, e não a obra, para deixar bem clara essa divisão (PITTA, 2016, p. 4).

Após a aquisição da performance de Ianês, foi realizada uma entrevista com o artista, nos moldes do International Network for the Conservation of Contemporary Art [INCCA], com a presença da conservadora Teodora Carneiro, do Núcleo de Conservação e Restauro; Giancarlo Hannud, curador na época; duas funcionárias do Núcleo de Acervo Museológico, formando um corpo de informações da obra, que foram agregados ao dossiê, além de outras recomendações, um histórico da performance na Pinacoteca e, a pedido de Ianês, imagens das apresentação no museu.

A coordenadora do Núcleo do Acervo Museológico que cuida da catalogação (Anexo I) das obras da Pinacoteca, Fernanda D'Agostino (2016), se recorda do recebimento da obra de Ianês pela equipe do museu, e compreende a responsabilidade de guarda de uma obra dessa natureza, mesmo porque a Pinacoteca é um museu público, e seu acervo é patrimônio do Estado.

Pitta (2016) destaca, ainda, que no passado alguns trabalhos não tinham preocupação de registrar as manifestações como obras de arte, o importante era o tempo espaço e o impacto com o público presente. Alguns desses trabalhos passaram pela Pinacoteca, hoje estão no Centro de Documentação da Pinacoteca, além de obras materiais, que os próprios artistas intitulam como performance, como é o caso de Nino Cais e Júnior Suci, cujos desenhos são para eles performances.

Maurício Ianês (2016) explica que a sua obra na Pinacoteca possui um script, um certificado da galeria que acompanha qualquer obra comercializada, levando as assinaturas dele e do galerista e a descrição do trabalho, acrescida de uma descrição detalhada feita por ele mesmo (Ianês), referente à ação. Porém, outra estratégia foi o compromisso firmado com a Pinacoteca em realizar um workshop em cada realização da ação, pela disponibilização dos funcionários, afinal são os que atuam, dependendo do desejo deles, totalizando oito participantes. A cada nova apresentação, os elementos que participaram, passaram pelo workshop orientado pelo artista, ou por meio de um vídeo que ele fez com orientações, disponível na Pinacoteca junto ao acervo da obra, com a 
ressalva de que os participantes podem efetuar adaptações, ou seja, "o trabalho vira um trabalho deles não mais só meu" (IANÊS, 2016, p. 12).

Outra performance que pertence ao acervo de Ianês é a obra "Recusa" (vide figura 17, que foi adquirida pelo Centre National des Arts Plastiques [CNAP], que também foi a primeira obra dessa natureza. Essa performance necessita da presença do artista para ser executada, pois essa foi uma condição do artista, criando uma coisa inusitada. Isso significa que, quando Ianês vier a falecer, a obra não poderá mais ser reperformada, restando somente os documentos, com a ressalva que a cada apresentação todos os documentos serão incluídos no acervo da instituição, que conservará a trajetória e história dessa ação. Esses documentos não têm caráter autônomo.

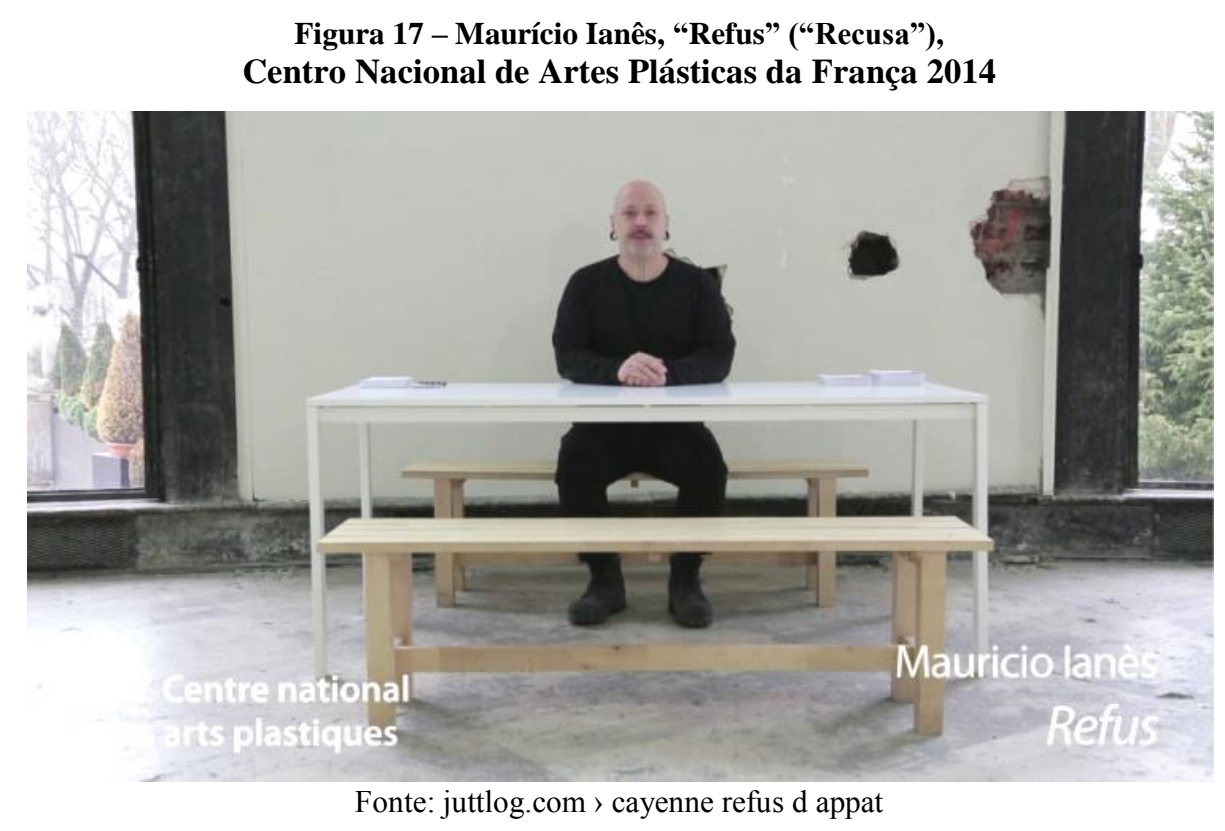

Uma colocação fundamental para o artista é o contexto na performance, o documento ou o registro não é suficiente em comparação com a ação ao vivo, como nas ações de Yoko Ono (figura 18). "Você pega até as instruções aí, como a Yoko Ono, é um papel com uma coisa datilografada, e aquilo é uma obra de arte, mas a obra de arte de fato é a ação, e a ação que ela sugere é olhe para o horizonte" (IANÊS, 2016, p. 11).

Outra abordagem apresentada por Ianês é referente à história oral, que há pouco tempo na história era uma forma eficaz de transmitir informações, com o agravante de cada vez que uma voz retransmitia alguma coisa, algo poderia ser acrescentado, enriquecendo a história. Contudo, hoje tudo fica registrado em livros e Ianês (2016, p. 11) acha esse formato bastante interessante e bonito: "o melhor documento do meu trabalho é a memória de quem participou". 
Em 1964 lança o livro Grapefruit, uma compilação de "instruções de obra de arte" (entre elas Hide \& Go Seek: "Se esconda até que todos se esqueçam de você. Se esconda até que todos morram.") e começa uma longa série de happenings.

- Em 1965 apresenta-se novamente no Carnegie Recital Hall com a sua performance Cut Pieces ("corte pedaços"), onde permanecia sentada, convidando o espectador a cortar com uma tesoura pedaços de sua roupa até ficar nua. Esta performance teve um impacto positivo na crítica.

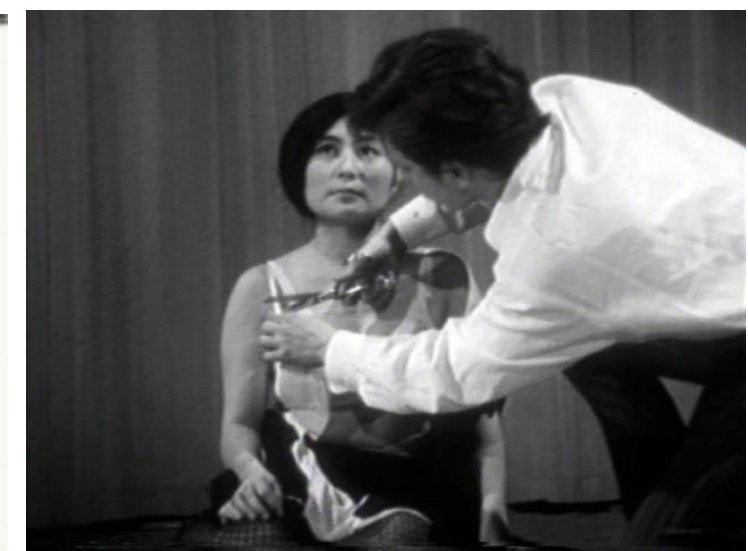

Fonte: https://pt.slideshare.net/claudiowww/trabalho-sobre-fluxus-yoko-ono

O performer Lourival Cuquinha (2017, p. 18) acredita que tudo pode ser efêmero, portanto, perece com o tempo, até mesmo um quadro na melhor tela, "a gente está em uma vírgula aqui no planeta e daqui a pouco pode acabar tudo". Quando o assunto é performance isso não é diferente, os registros podem garantir sua história ou pesquisa e oportunizar ao público que não a vivenciou se aproximar da ação, mas segundo esse performer: "Ela também está ali para viver o momento que ela vive, você quando vê o vídeo não é o que aconteceu, você já está vendo a história e a história é o que se conta do que aconteceu, é uma questão de escala temporal" (CUQUINHA, 2016, p. 18).

A sua obra "Parangolé", que fará parte do acervo do MAM-SP (Anexo III), carrega, como toda obra, um ofício, uma página escrita que contém além da descrição, questões a respeito de seu empréstimo para outros locais fora de São Paulo, porque a farda utilizada pelo ator é fundamental ser da cidade onde a ação acontecer para ter significado, ou seja, deve representar a autoridade, a polícia local. Outro aspecto destacado pelo ator é que deverá, preferencialmente, utilizar o ator escolhido por Cuquinha na encenação original, Luís Vagner, por ser negro, forte e representar um estereótipo de policial; ou ele deve servir como referência, porque um dia ele também morrerá, mas o importante é a ideia de um modelo com tipo de policial. 


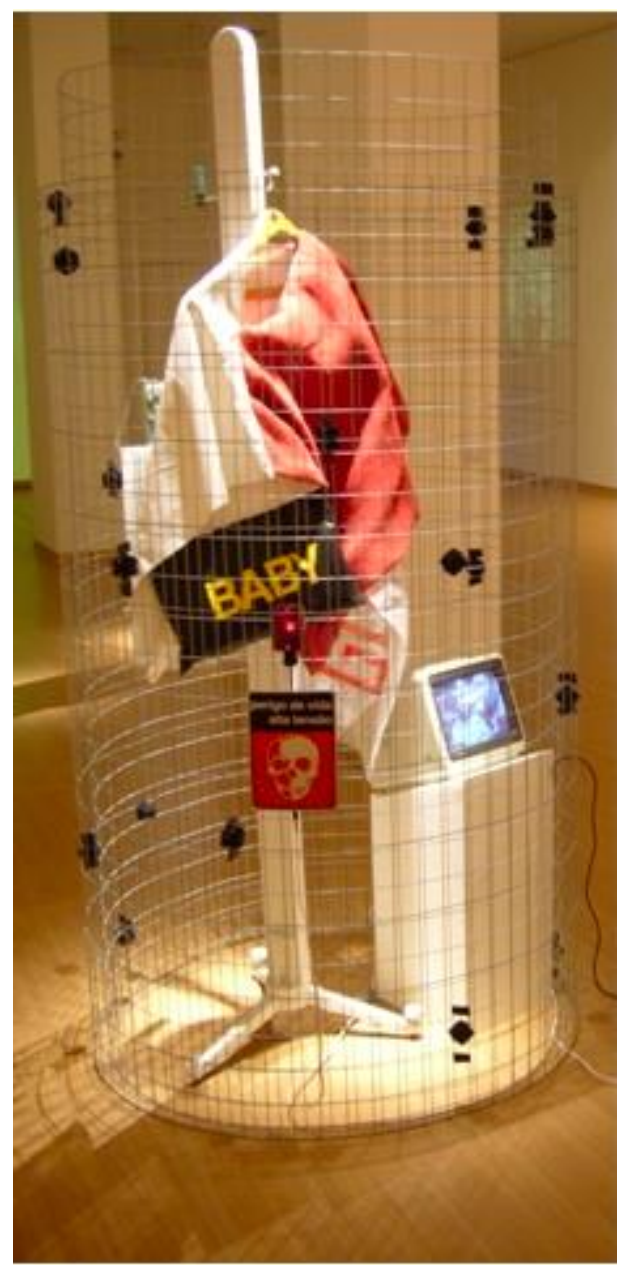

Fonte: https://www.artsy.net/artwork/lourival-cuquinha-parangole

Cuquinha em sua descrição apresenta a arma que deve estar no acervo $^{23}$ e um documento legal, normativo, porque é uma arma de fogo e a legislação deve ser respeitada. Em paralelo, com a questão de ser uma performance, o performance destaca "que é uma legalização de um objeto ilegal, por meio da arte" (CUQUINHA, 2016, p. 11); então ela também é um objeto... é uma estratégia de inclusão da obra no acervo. E isso tudo também é considerado, por ele, como história e arte ao mesmo tempo, uma extensão da obra de arte, ou uma característica da arte. No caso da performance, quando vivenciada é um momento singular, que oferece espaço a conclusões subjetivas, de convivência, de viver aquele momento, até mesmo quando alguém relata o que viu e vivenciou a terceiros é sempre uma contribuição, mas cada trabalho é único e seu registro também.

Por outro lado, segundo Cuquinha (2016), não é possível pensar em eternizar um trabalho, nenhuma obra tem esse poder. De acordo com essa performance, talvez

\footnotetext{
${ }^{23}$ Até a finalização desta dissertação a obra ainda não havia sido tombada.
} 
trabalhos das décadas de 1980 e 1990, depois de mil anos, possam ser consideradas eternas ou pelo menos a ideia registrada, mesmo porque a ação se dá nas mentes dos presentes e isso não pode ser registrado, o que é passível são os relatos pessoais, as impressões de quem a vivenciou, talvez essas reflexões sejam o mais importante.

O processo de criação para Cuquinha, conforme ele o descreve, normalmente inicia com um texto, uma ideia ou um projeto, que esclarece a ação, ou pode até ser enviado para um edital. Em seguida, ocorre o plano da materialização, em alguns casos é enviado a uma curadoria para explicar uma foto ou a própria ação. Esse caminho germina e a descrição do trabalho se completa. Assim, tem-se três etapas: o projeto, a realização e a síntese, que sempre estará sujeita ao diálogo, que envolvem questões éticas, sociais, status quo, o público e principalmente o indivíduo. Para o artista, o registro é história e obra ao mesmo tempo, ou seja, o processo é quase uma extensão da obra.

A artista Laura Lima (2017) esclarece que inicialmente seu trabalho não era denominado performance. Segundo seu próprio olhar foi uma postura diante do conteúdo, que desenvolvia em arte, sua opção em trabalhar com o corpo como suporte. As suas obras "Quadris de Homem=Carne/Mulher=Carne" (figura 20) e "Bala de homem" (figura 21) foram as primeiras performances adquiridas por um museu, o MAM-SP, e tombadas como performance no Brasil, "o que causa um estranhamento porque não era o vocabulário que eu estava aplicando" (LIMA, 2017, p. 1). Seus trabalhos eram resultados de camadas de construção, para ela não eram performances, como ela identificava historicamente no trabalho de alguns colegas na ocasião. Ela ressignificou seu glossário e finalmente começou a acreditar que isso era parte de sua produção artística, por entender ser mais elástico, mesmo porque até uma pintura, que não utiliza tinta é considera uma obra de arte. Da mesma forma, uma ação com pessoas ou animais pode ser tratada como performance. 
Figura 20 - "Quadris de Homem= Carne/Mulher=Carne", Laura Lima, 1995

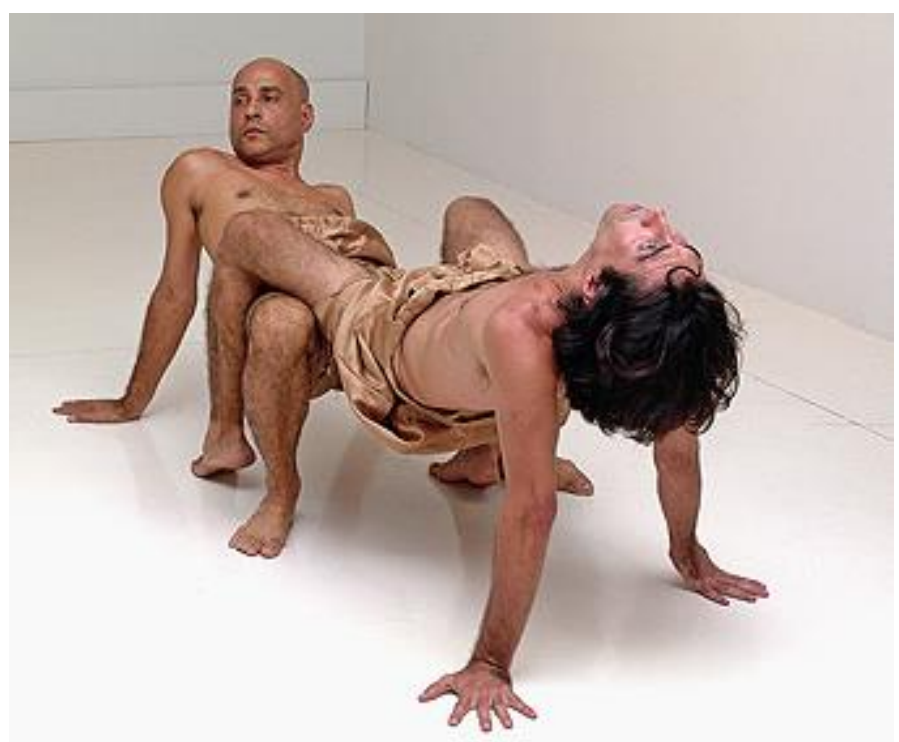

Foto: Sérgio Guerini, Itaú Cultural

Fonte: ENCICLOPÉDIA Itaú Cultural de Arte e Cultura Brasileiras. São Paulo: Itaú Cultural, 2018. http://enciclopedia.itaucultural.org.br/obra63227/quadris-de-homemcarnemulhercarne

Figura 21 - Bala de Homem = Carne/Mulher = Carne, Laura Lima, 1997

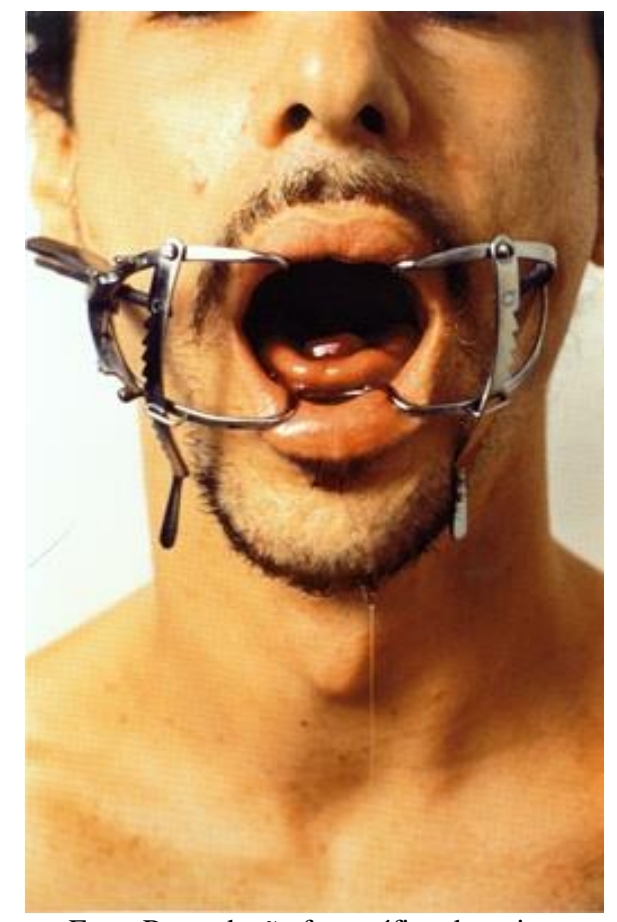

Foto: Reprodução fotográfica da artista

ENCICLOPÉDIA Itaú Cultural de Arte e Cultura Brasileiras. São Paulo: Itaú Cultural, 2018. <http://enciclopedia.itaucultural.org.br/obra23380/bala-de-homem-carnemulher-carne>

Pressupondo que vivemos em um mundo de enunciados e catalogações, Laura Lima (2017) pensa de forma mais pragmática, acredita que em artes existem terminologias que os museus acessam, mas para ela "isso é uma forma obtusa de chegar até o que a gente discute, porque vai que um artista realmente vai falar sobre escultura, fazendo uma coisa que a gente diria que é somente desenho que está na parede" (LIMA, 
2017 , p. 2.), isso pode acarretar em várias perdas no campo da pesquisa. Laura (2017, p. 2), no entanto, tem clareza que seu trabalho foi de certa forma uma abertura junto às instituições que alertavam: "prestem bem atenção, nós não colecionamos só a questão do objeto, nós podemos lidar com uma obra, que se coloca assim como tal, que tem um caráter performativo". Resumidamente, o termo performance estava e ainda está sendo utilizado para catalogar obras dessa natureza, que utilizam o tempo e espaço.

A experiência estética de Laura Lima (2017), uma artista como ela própria anuncia, continua viva e ativa. A artista afirma que as orientações de suas obras nos museus não são estanques, ela continua refletindo sobre as obras e quando necessário, segundo seus critérios, ela acrescenta ou tira informações e dados, "a partir até da observação de como é que essa obra se deu e das condições de quando ela foi refeita, (...) outras condições, em outra instituição ou em outro país, coisas que eu fui percebendo" (LIMA, 2017, p. 4). Mas ela garante que a obra, mesmo com esses acréscimos, continuará com a mesma proposta inicial. Normalmente seus trabalhos devem ser executados desde o primeiro dia até o final da exposição ou proposta de apresentação; outro comentário da artista é não expor os objetos utilizados nas ações separadas como obra individual, pois fazem parte do todo, da ação corporal, em respeito à aura da obra (LIMA, 2017).

Um exemplo das reflexões de Laura no curso do tempo aparece na obra "Marra" (figura 22), de 1996, “dois homens lutam com a cabeça conectada por um capuz, até que não tenham mais força" (INHOTIM, s.d.), na qual a artista percebeu que seria necessário um grupo grande de homens para realizá-la, já que as duplas deveriam lutar até a exaustão, usando a energia vital. Dessa forma, carecia de trocar as duplas durante a execução, mesmo porque ela deveria acontecer no horário da instituição. Esse discernimento é observado por ela durante as apresentações, já que em geral não são ensaiadas. Nessa obra, como as demais ações da artista, para sua execução é necessária a contratação de artistas (conforme Anexo IV).

Durante as repetições de apresentações a artista aproveita para entender mais profundamente suas criações. Outra situação peculiar em obras com essas qualidades, devido a sua fragilidade, ocorreu quando o contratado, "a pessoa que eu dei instrução, ela reverteu e fez alguma coisa a mais do que seria, (...) a minha obra estava conversando comigo. A obra estava dizendo quão frágil podem ser as instruções que são dadas e ela existindo..." (LIMA, 2017, p. 5). Evidentemente que o participante que fez essas alterações o fez consciente, pois até o momento da execução passou por orientação. Sobre esse prisma, a instituição precisa estar atenta às informações extras da artista, que sempre 
serão uma ferramenta eficaz, apesar da artista não ter convicção que essa atualização esteja no contrato das instituições.

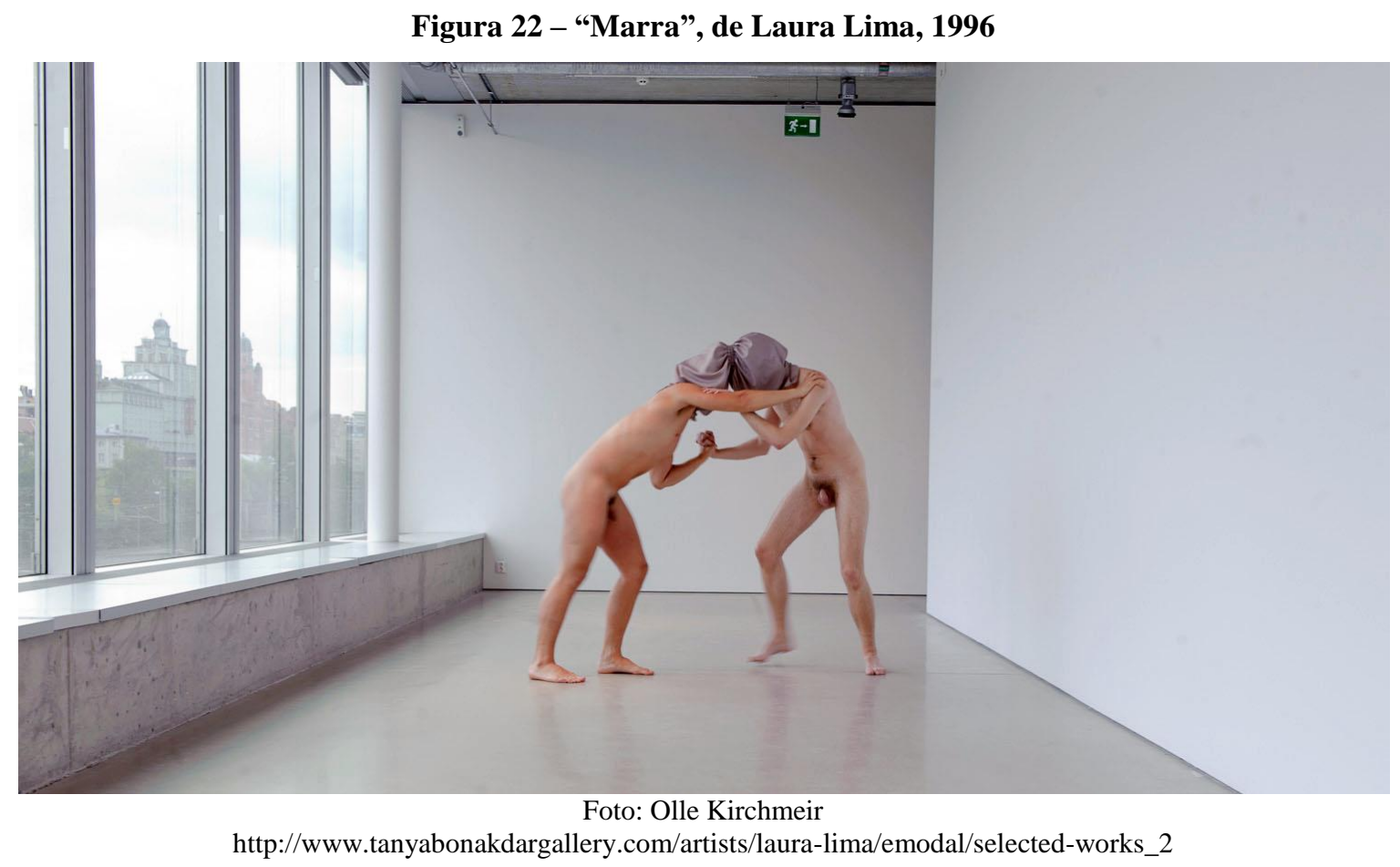

Laura Lima (2017) comenta que quando vendeu as primeiras obras "Bala de homem = carne / mulher $=$ carne" (1997), e os "Quadris de homem $=$ carne $/$ mulher $=$ carne" (1995), “eu fiz um documento a mão do meu jeito, no calor da hora”. Lima (2017) complementa: “(...) Eu já pensava, eu continuo pensando, como são as instruções, como é que eu vou fazer a entrega dessas instruções” (LIMA, 2017, p. 6). Seu método de trabalho deixa pequenas coisas abertas, e destaca que a instituição também é instruída. A catalogação, segundo Laura Lima (2017), pensando na linha do tempo, utiliza ferramentas estanques, categorias, no futuro, contudo poderão ser ampliadas. Ela faz uma analogia com o processo de restauração, que não utiliza procedimentos definitivos, pois a tecnologia está sempre evoluindo e novas técnicas sendo descobertas, que pouco ou nada interferem no original, com as nomenclaturas da catalogação. O mesmo poderia acontecer e então novos termos seriam capazes de classificar, admitindo que isso seja possível, do que as que estão sendo utilizadas até o momento.

A artista relembra de uma situação peculiar na qual o museu a indagou sobre a possibilidade de integrar ao arquivo da obra um diário feito por uma das pessoas que fizeram o "Palhaço", e ela consentiu por acreditar que alargava o histórico da obra. 
Figura 23 - Registro/instruções de ações de Paulo Bruscky, em exposição individual na Galeria Nara Roesler, 2 de agosto 2017

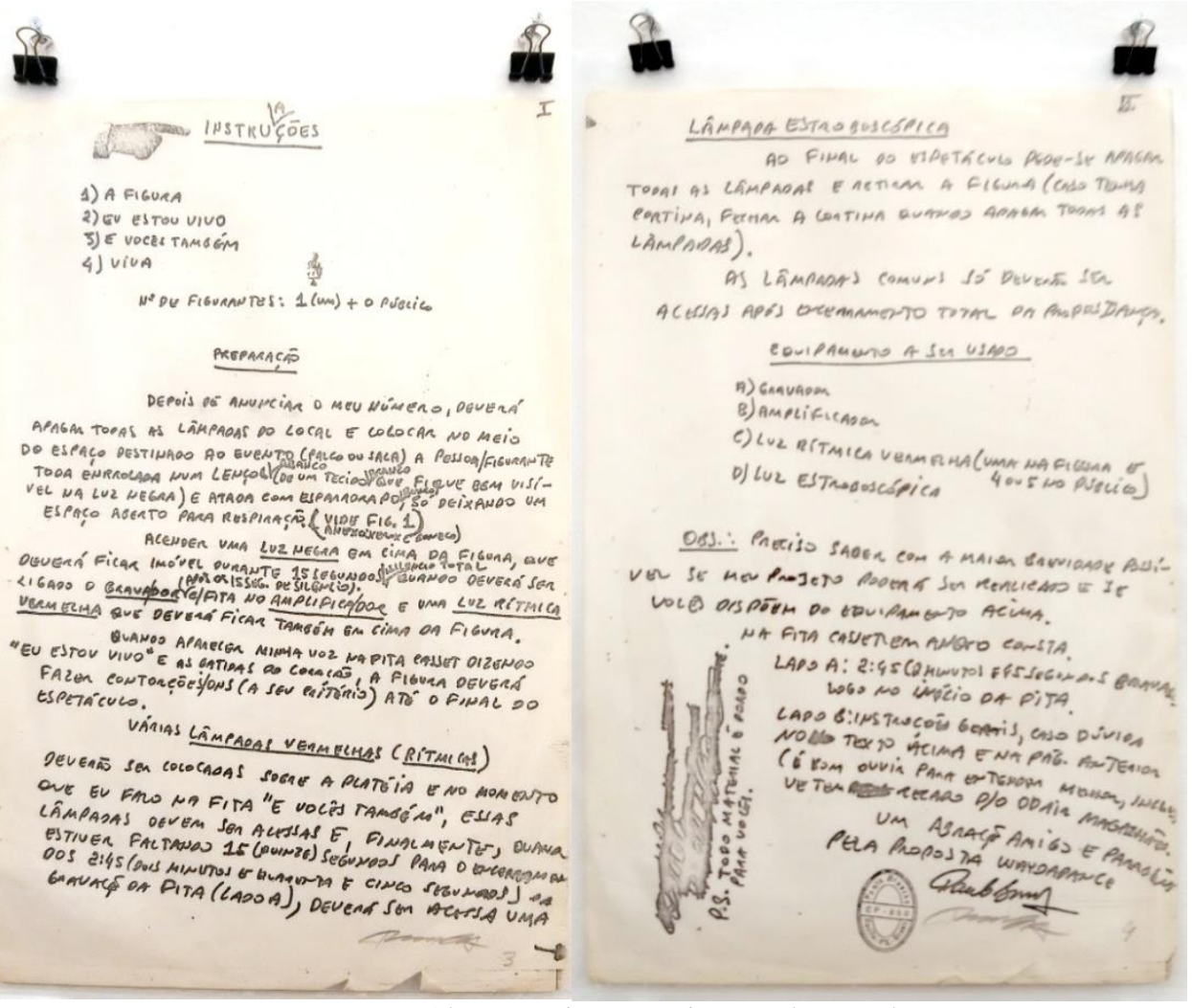

Foto: Joseane Alves Ferreira. Exposição Paulo Bruscky.

Galeria Nara Roesler (2 ago. 2017)

Outro exemplo se pode observar com Paulo Bruscky, artista reconhecido no Brasil e no exterior como um importante renovador da arte contemporânea, em sua recente exposição individual (maio a agosto de 2017), na Galeria Nara Roesler, em São Paulo, ele apresentou performances e registros, com muitas de suas experiências, trabalhos interativos, vestígios de ações, além de possibilitar ao visitante, levar para casa suas criações, propostas pelo artista, como o projeto, "Xeroxperformance" (1980//2017), porém, o que chama a atenção de quem por lá passou, são os "rascunhos", instruções manuscritas pelo artista, expostos, na parede como pinturas, gravuras ou fotos, de ações, que Bruscky criou, oportunizando vivenciar, seu processo criativo, além das orientações para que uma ação aconteça. 


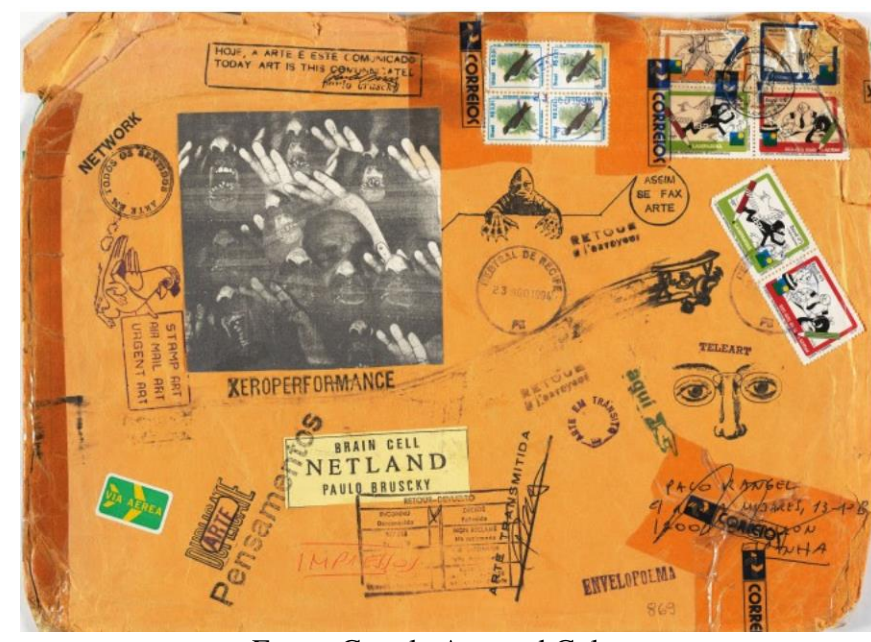

Fonte: Google Arts and Culture

https://artsandculture.google.com/asset/xeroxperformance/vgFn0C9Wwj5IZA

Pode-se concluir que é sine qua non manter viva a memória dessa linguagem, tanto por arquivo, informações e fatos, registros, quanto por experiências ouvidas ou vivenciadas. Os museus, as galerias e os artistas têm uma tarefa árdua para garantir ao público e aos pesquisadores a experiência de ver e rever essas manifestações, seja presencialmente ou por registros, oportunizando as várias leituras que uma obra de arte pode proporcionar a seu público, abrindo portas para fruição e reflexão que o diálogo oferece entre a obra, o artista e visitante.

\subsection{RESÍDUOS}

Os resíduos são outra possibilidade de as instituições constituírem seus acervos de performance. Os resíduos consistem no resultado material das apresentações, por exemplo, o conteúdo residual e material, a roupa utilizada pelo artista, os objetos, móveis, enfim os materiais que faziam parte da apresentação.

True Rouge (1997) é um exemplo determinante, pois são resíduos de uma ação, obra do artista Tunga a qual ele denomina como "instauração", que basicamente é fruto de uma performance ou instalação que se encontra em uma das Galerias de Tunga, em Inhotim $^{24}$. Em sua fase original, personagens despidos se relacionaram com os objetos,

\footnotetext{
24 “O Instituto Inhotim começou a ser idealizado pelo empresário mineiro Bernardo de Mello Paz a partir de meados da década de 1980. A propriedade privada se transformou com o tempo, tornando-se um lugar singular, com um dos mais relevantes acervos de arte contemporânea do mundo e uma coleção botânica que reúne espécies raras e de todos os continentes. Os acervos são mobilizados para o desenvolvimento de atividades educativas e sociais para públicos de faixas etárias distintas. O Inhotim, inaugurado em 2006, é uma Organização da Sociedade Civil de Interesse Público (OSCIP) e tem construído diversas áreas de interlocução com a comunidade de seu entorno. Com atuação multidisciplinar, o Inhotim se consolida, a cada dia, como um agente propulsor do desenvolvimento humano sustentável” (INHOTIM, s.d. p.1).
} 
vidros que estavam suspensos, e no seu interior continham líquido vermelho viscoso. "Presentemente, diferente do momento da performance, não há a possibilidade de entrar nu para apreciação da criação, consequentemente, a experiência é formada através do capital cultural agregado, convertendo-se em compreensão sobre o exposto" (COTE; GAIONE, 2017).

Contudo, a obra que é diferente da performance foi ressignificada, obra e público criam vínculos, por meio da vivência e história pessoal, vão tecendo um mundo repleto de interpretações e códigos de leituras da arte e do mundo. Na performance o artista provocava a reflexão das relações afetivas, das dominações sempre presentes, dos vínculos pessoais, e a fragilidade dessas se romperem, tais quais os materiais por ele apresentados, vidros, fios, líquidos. $\mathrm{Na}$ instalação homônima estas sensações são retomadas, mesmo sem a presença dos atores, porque outras conexões são acionadas. Ao mesmo tempo trata-se da mesma obra e de outra obra diferente.

Figura 25 - "True Rouge", Tunga, 1997

(redes, madeira, vidro soprado, pérolas de vidro, tinta vermelha, esponjas do mar, bolas de sinuca, escovas limpa-garrafa, feltro, bolas de cristal, 1315 × 750 x $450 \mathrm{~cm}$ )

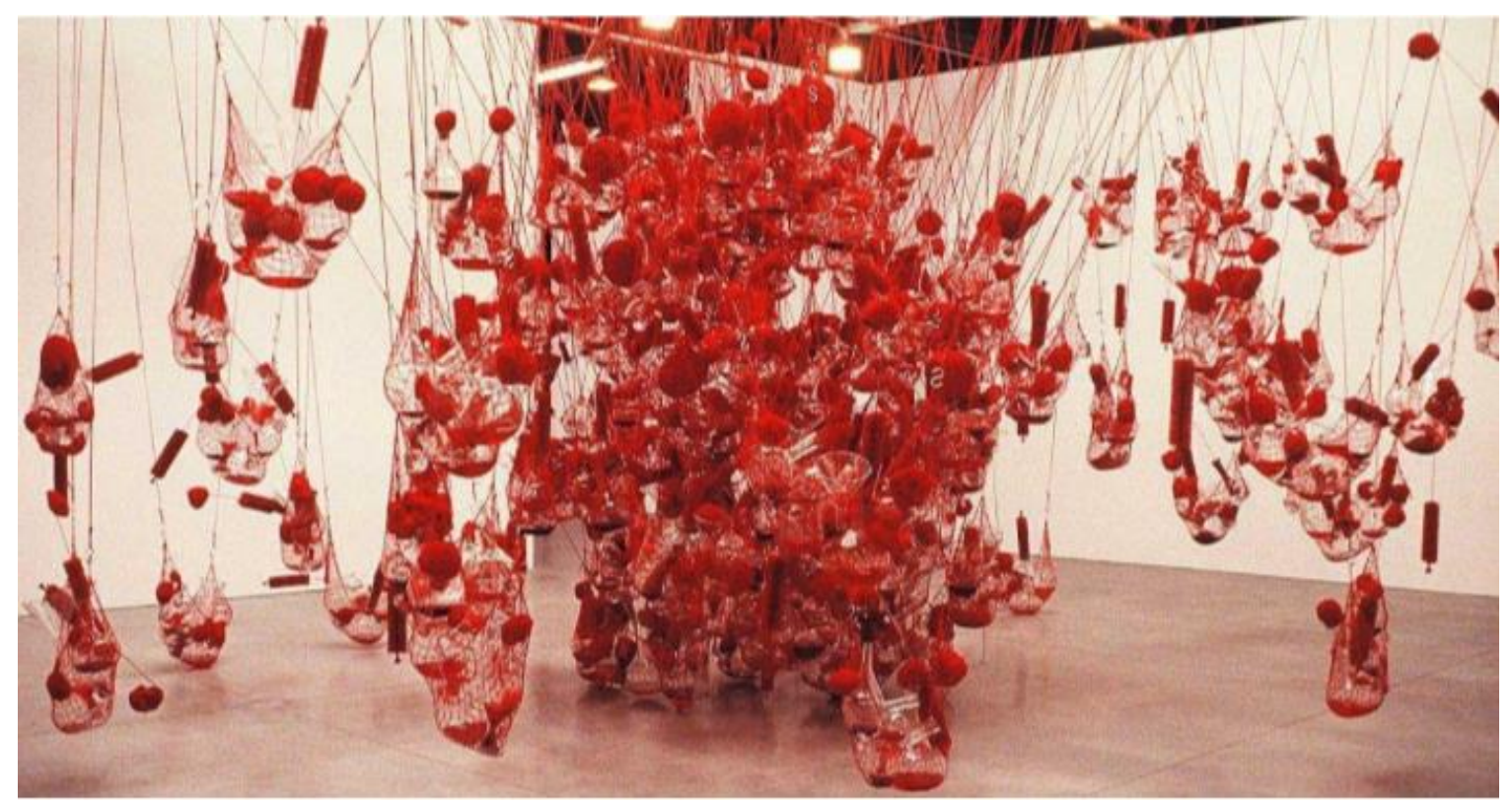

Fonte: Galeria True Rouge (COTE; GAIONE, 2017)

Da mesma forma, segundo Frazão (2016), os acervos de performance nas instituições são constituídos com registros, documentos, mas também com os resíduos materiais da performance, embora, em sua opinião, esses sejam caminhos diferentes, eles são caminhos de guarda e catalogação que o museu conserva como memória material da ação, já que não é possível se guardar o artista ou seu corpo.

A roupa que o performer usou, ou o resultado da performance, a cera que foi usada, enfim esses os conteúdos residuais da performance, isto 
tudo é incorporado ao acervo, mas como elemento cênico de um ato, que já passou, tem um valor em si, que é um valor histórico, e tem o valor estético de ser esse registro da presença humana, da ação humana (FRAZÃO, 2016, p. 8).

A SP-Arte 2017 ocorreu no Pavilhão da Bienal ${ }^{25}$ em São Paulo, feira que comercializa arte e aproxima galeristas, colecionadores e apreciadores de arte. Dentre as várias obras expostas para venda havia resíduos da performance "A Escritura", de Maurício Ianês, que consistia nos objetos: camisa de algodão, livro, tinta indiana e tempera, o resultado material da ação de Ianês. A descrição dessa ação que foi apresentada no Festival Internacional de Performances de Québec, pela Galeria Vermelho e no SESC Pinheiros e consta nos registros da Galeria Vermelho, que representa o artista.

"A Escritura", Maurício Ianês deverá estar sentado, vestindo uma camiseta de malha branca, de mangas curtas, e calças pretas. A cadeira utilizada durante a ação deve ser feita em madeira clara, e ter formas retas e simples. Deverão ser confeccionadas uma mesa quadrada, com tampo de $80 \mathrm{~cm}$ x $80 \mathrm{~cm}$ e altura que seja confortável com as medidas da cadeira. Outra cadeira deve ser colocada do outro lado da mesa, em frente à Ianês. Esta cadeira ficará à disposição do público. Sobre a mesa, em frente a Ianês, deverão estar um caderno ou livro em branco com capa dura preta, de formato variável, e um copo com tinta nanquim/ China ink. Ianês ficará imóvel, com a mão esquerda pousada sobre a mesa ao lado do caderno, e o copo com tinta deverá ser colocado do lado direito do caderno, alinhado com a borda superior deste. Durante esta primeira fase da ação, Ianês irá olhar fixamente para as pessoas do público, imóvel, esperando que alguém se sente à sua frente.

A segunda fase da ação terá seu início quando alguém do público se sentar na cadeira vazia à frente de Ianês. Neste momento, Ianês irá olhar a pessoa nos olhos, e irá encher a boca com a tinta que está no copo. Sua mão esquerda irá começar a tremer, como se estivesse prestes a fazer alguma ação. Ianês irá então abrir a boca e o caderno em branco, na primeira página, e começar a deixar escorrer a tinta sobre o caderno. Com a mão direita irá virar violentamente as páginas do caderno, deixando que a tinta que escorre de sua boca manche as páginas do caderno. Quando a pessoa levantar, Ianês irá parar a ação, que só será retomada quando a próxima pessoa se sentar à sua frente. Caso a pessoa anterior permaneça sentada, Ianês continuará a ação até que a tinta em sua boca acabe. Ele irá então enchê-la novamente com a tinta, e proceder manchando as páginas do caderno, virando-as.

A ação tem duração variável, e terá seu fim quando o caderno chegar ao fim, tendo todas as suas páginas pintadas. Como documento da ação, a camiseta branca e o caderno manchado poderão ser expostos independentemente, como obras documentais da ação. As cadeiras e a mesa poderão ser arquivados e reutilizados, no caso de outra apresentação da obra, ou serem fabricados novamente, em uma próxima apresentação (GALLON, 2017).

\footnotetext{
${ }^{25}$ O Pavilhão Ciccillo Matarazzo é um projeto arquitetônico de Oscar Niemeyer (1957), e está localizado no Parque do Ibirapuera. Desde sua inauguração vem sendo utilizado como espaço para as edições da Bienal de Arte, principal exposição de arte no Brasil, além de outros eventos.
} 


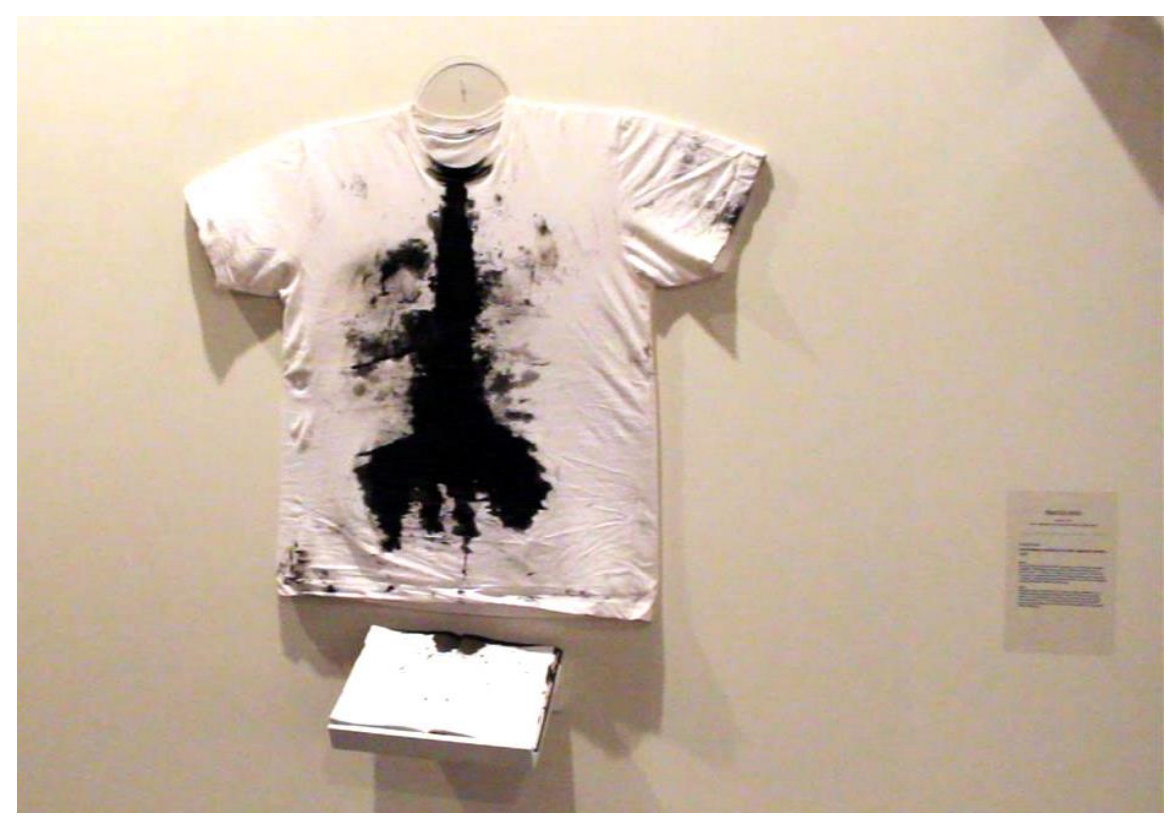

Foto: Diogo Gomes dos Santos, 2017

O que se pode averiguar é que os resíduos da obra "A Escritura", que foram tratados como peças comercializáveis, contribuem e podem remeter à experiência artística que aconteceu ao vivo, ainda, priveligiam reflexões, provocações e interpretações do receptor por meios desses elementos.

No trabalho "Recusa" (Refus), de Ianês (figura 17), que consta no acervo do CNAP na França, os documentos dessa obra são acrescidos de fichas simples, nas quais o público escreve em cada apresentação, a mesma ficha de catalogação utilizada nas bibliotecas e canetas, ambas as mais baratas comercializadas em território francês, que gerou uma indagação: como conservar esse material barato nos dias atuais, e no futuro será que continuará existindo? Qual será o valor dessa peça, caso seja rara? Mas, para Ianês, em última estância não é relevante ser essa caneta, apenas deverá ser barata e fácil de adquirir. Em contrapartida, como a ação só irá acontecer enquanto o artista estiver vivo, a instituição debateu com o artista maneiras de conservar seu corpo, sua saúde, vida longa, já que ele era o objeto da ação, possibilitando maior disponibilidade para o artista reperformar a ação. Naturalmente Ianês afirmou: "de jeito nenhum, vocês têm o poder sobre o trabalho e não sobre o meu corpo" (IANÊS, 2017, p. 4).

Em o "Parangolé" (figura 28), de Cuquinha, o nome da obra tem seu nascimento devido à obra homônima de outro artista Helio Oiticica (vide figura 27), conforme apresentado a seguir:

Com o Parangolé você faz o que quiser" o Parangolé é fazer o que quiser com a manta, é a liberdade de uso, de criação, de introjeção naquele ativador que é a manta. Ela não é exatamente a manta. Então o Parangolé, você faz o que 
quiser, e aí existe uma percepção social que com a farda de polícia, você faz o que quiser também (CUQUINHA, 2017, p. 8).

Figura 27 - “Os Parangolés”, Hélio Oiticica, 1972

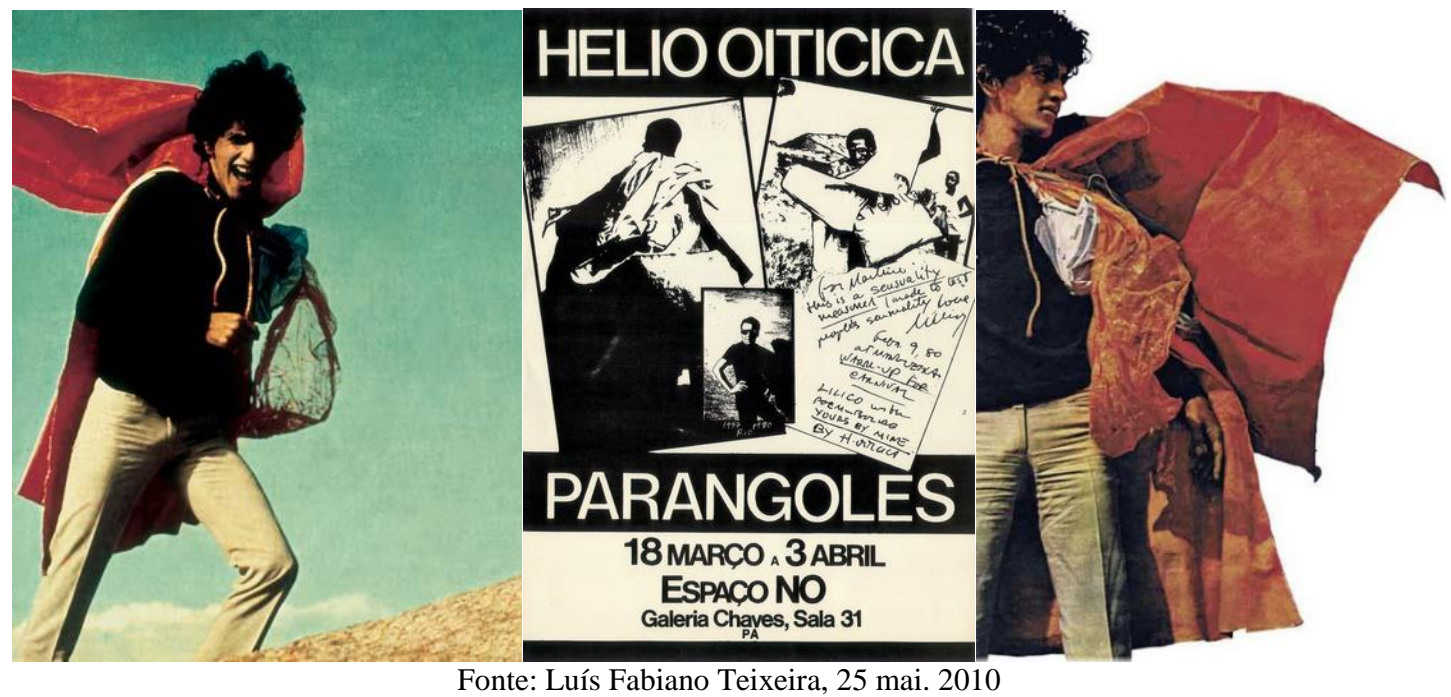

http://www.culture-se.com.br/noticias/84/os-parangoles-de-helio-oiticica

Figura 28 - Performance "Parangole" de Lorival Cuquinha

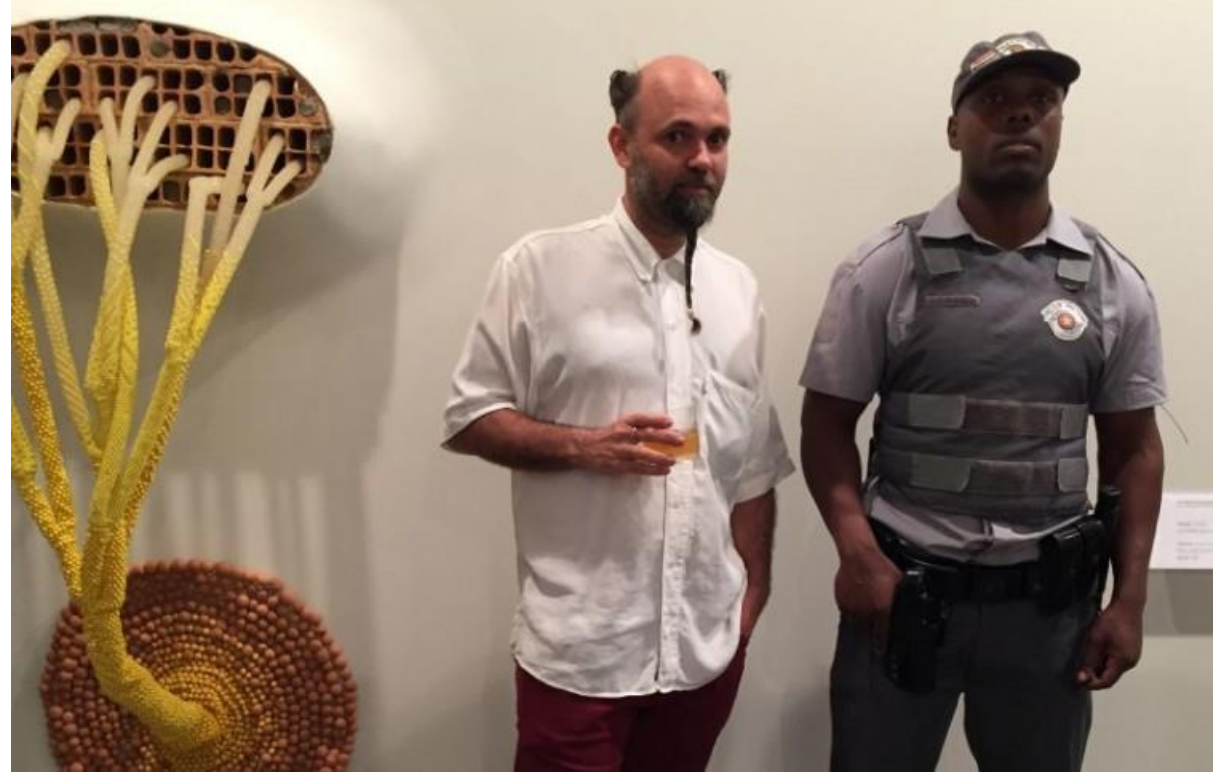

Fonte: https://www.select.art.br/quanto-custa-uma-performance/, 2016.

A partir daí o artista Cuquinha (2017) constatou que o pensamento de Oiticica e sua obra continham um teor social, ou seja, o que o objeto farda carrega, o processo de absorção que o material projeta, associado à liberdade de criação que esse planejamento propõe, não significava apenas uma peça de vestimenta. Esse nome trazia embutido uma objetificação, farda, arma, cassetete, o paramento completo, mas também o corpo do ator, pois se tratava de uma ação, uma performance. Cuquinha (2017), no entanto, considera importante a distinção, principalmente em relação à materialização que integra o acervo, ressaltando que essa farda só tem sentido em São Paulo, e não em qualquer outro local. 
Não obstante, o material estaria imbricado de significados, como um fantasma que sustenta a vestimenta.

Cuquinha (2017) propôs ao MAM-SP utilizar a indumentária do policial, a farda, como objeto de exposição, acrescida de legenda. A mesma farda utilizada na performance, intitulada "Parangolé", como substrato desenvolvido a partir dessa ação.

Um dado interessante é que a farda da exposição foi alugada em um recinto com uniformes originais, autorizados pela polícia, que normalmente são utilizadas para cinema, comerciais, pois devido seu caráter de uniforme oficial, requerem autorização assinada pelo solicitante, mesmo porque esse tipo de peça não existe no mercado para venda. As opções para adquirir essa peça seriam: enviar um oficio, da instituição - no caso, o MAM-SP - em parceria com o artista para um coronel que, em geral, tem várias vestimentas, solicitando doação para performance sem a arma e o cassetete, como obra do acervo; a outra opção seria encomendar a confecção da farda com alguém autorizado, tudo devidamente registrado. O artista está encaminhando uma dessas possibilidades, junto com o curador do MAM-SP (CUQUINHA, 2017).

A artista Laura Lima (2017) não permite que os resíduos, as vestimentas, os aparatos das suas performances sejam expostos separados das ações por fazerem parte do todo da obra, da apresentação, e isso consta nas instruções da autora. O colecionador, ao adquirir a obra, deve estar ciente da especificidade da obra, salvo uma proposta diferenciada de curadoria que apresente obras fora do contexto e ideia original, subvertendo a obra em si, porque a arte é um campo livre, mas a ideia de expor os vestígios das experiências para essa artista é inconcebível.

Nos museus, onde suas obras se tornaram acervos é comum se observar objetos como parte integrante das ações, são elementos como o aparato de metal que o performer utiliza na boca em "Bala de homem = carne / mulher = carne" que, segundo Laura, são parte do histórico e da existência da obra. Quanto ao "Palhaço com buzina reta - monte de irônicos", obra do acervo do MAM-SP, Laura Lima (2017) atualiza a cabeça sempre que possível, pois a peça é muito utilizada em exposições e ela deseja continuar reciclando a parte material da obra enquanto estiver viva, por entender que a materialidade, a vestimenta, é parte integrante de sua ação. 
Figura 29 - "Palhaço com buzina reta - monte de irônicos", de Laura Lima, 2007

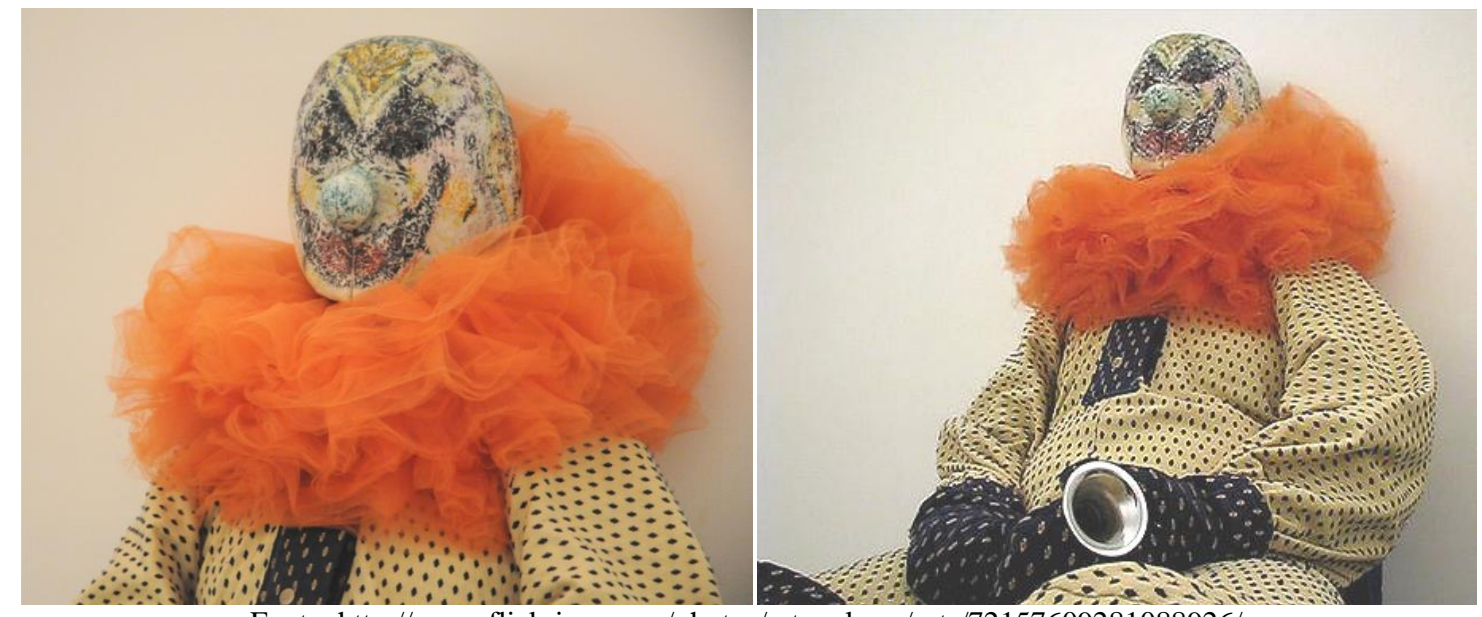

Fonte: http:/www.flickriver.com/photos/artexplorer/sets/72157609281088926/

Outra interpretação de resíduos ou vestígios de uma performance passa pelo viés da comercialização, tal como ocorre com outras linguagens que oferecem ao visitante de muitos museus souvenirs das obras expostas. De acordo com Naira Ciotti (2017), que sempre foi apaixonada por Lygia Clark, o MAM do Rio de Janeiro fez uma exposição da artista e Naira viajou até essa cidade com o único intuito de deleitar-se frente ao trabalho de sua heroína; mas chegando lá, se deparou com um guarda-chuva escrito Lygia Clarck, que estava à venda no museu. Para Ciotti foi uma experiência horrível, afinal, não era obra da artista. Souvenir de performance, segundo ela, não entra sequer no âmbito da discussão, por ser puro consumo.

O MAM-SP em 2010, sob a curadoria de Rui Moreira Leite, resgata o discurso contundente de um artista revolucionário, com a exposição: "Flávio de Carvalho - A cidade do o homem nu" que dentre as diversas obras apresentou New Look - Traje do "Novo Homem dos Trópicos" (1956), já abordado nesta dissertação. 
Figura 30 - "Experiência n" 3", ou "New Look" - Traje do "Novo Homem dos Trópicos", Flávio de Carvalho (1956)

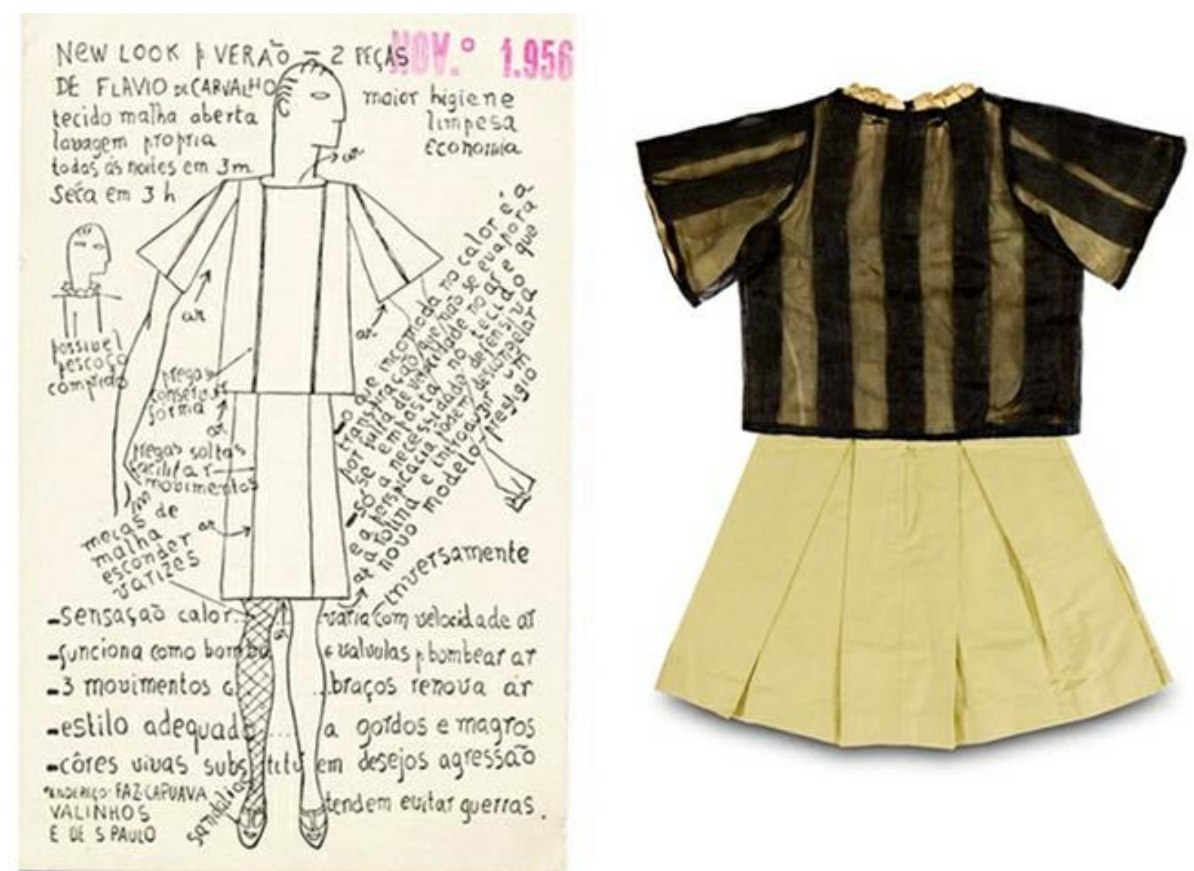

Fonte: Nas entre linhas (2012)

Com uma caminhada no centro de São Paulo uma ação, ou melhor, "experiência" como preferia denominar Carvalho, esse artista desfilou o que definiu como figurino ideal para homens dos trópicos. Porém, na exposição, o que o visitante contemplou não foi Carvalho caminhando com sua nova tendência estilística, mas o vestígio, a roupa e registros que ele criou, dando a dimensão de suas inovações marcadas pelo antagonismo de ideias e convenções.

\subsection{FOTOGRAFIA}

O período histórico em que nasceu a fotografia e o cinema já coloca essas linguagens artísticas em um contexto moderno e contemporâneo, momento histórico que a produção artística e os meios de comunicação apresentam características singulares no que se refere à originalidade de tema, formatos e reprodução.

Segundo Argan (1993), o fenômeno do aparecimento da fotografia em 1839 causou impactos profundos aos pintores da época. Além disso, a produção industrial das câmeras e as grandes transformações na psicologia da visão causaram uma enorme influência sobre o direcionamento da pintura e o desenvolvimento das correntes artísticas. Há um deslocamento de serviços sociais do pintor para o fotógrafo que leva os artistas a assumirem que, se existia um problema de visão, se deveria definir a distinção entre os tipos e funções da imagem pictórica e da imagem fotográfica. Ao mesmo tempo, o 
fotógrafo era entendido como um ser que manifesta suas inclinações estéticas e psicológicas, na disposição da luz e de enquadramentos. Esse novo paradigma pode ser comparado com o advento do cinema.

Desde meados do século XX, existem personalidades fotográficas (por exemplo Nadar) da mesma forma que existem personalidades artísticas. Não há sentido em perguntar se "fazem arte" ou não; não há qualquer dúvida em admitir que os procedimentos fotográficos pertencem à ordem estética (ARGAN, 1993, p. 78).

A Seção de Catalogação e Documentação - Divisão Técnico-científica de Acervo do Museu de Arte Contemporânea da Universidade de São Paulo [MAC-USP] compreende os registros de performance como ações que ocorrem em tempo/espaço específicos. Em um primeiro contato, considerou-se ser impossível tombar, nessa manifestação artística, apenas seus registros de ação (filme, fotografia, slide etc.) ou projetos (roteiro, story board etc.). As obras catalogadas na instituição são os registros de performance (Anexo IV) e, por não serem tratadas como obras do acervo, não podem ser reexecutadas a critério do museu (CABRAL, 2017). Um número significativo desses registros foi enviado "para participar de mostras, que ocorreram no MAC nos anos 70, mas as ações já haviam sido executadas" (CABRAL, 2017). O MAC, sendo um museu que, no seu cerne, atua com arte contemporânea, reconhece a performance como forma de manifestação que traduz a diversidade do universo artístico cultural contemporâneo.

Algumas interfaces da linguagem performática comungaram com essa instituição, por exemplo, ações que ocorreram em outros locais na cidade de São Paulo, nas quais os materiais presentes resultaram em instalações bem como ações que aconteceram no museu foram registradas apenas por fotografias. O MAC também recebeu doações de registros fotográficos de performances que estão incorporadas no acervo, como a "Performance Intervensão Movimento de Arte Pornô" de Eduardo Kac (1982), registrada na plataforma fotografia em gelatina e prata sobre papel, com dimensão de 18 x 23,9 cm, doada pelo artista. 
Figura 31 - Performance Intervensão Movimento de Arte Pornô, de Eduardo Kac (1982)

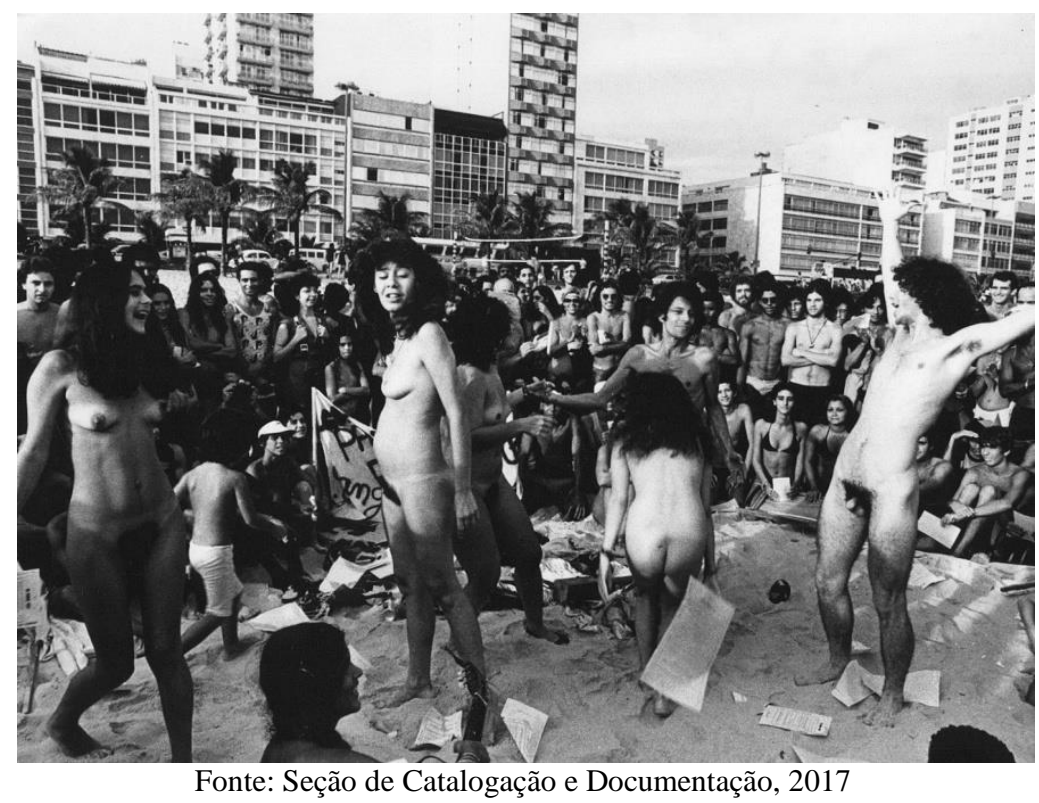

Segundo Ianês (2017), preservar historicamente uma ação, na qual o principal teor seja a experiência coletiva, mote de seu trabalho, o artista que acredita na desierarquização das relações junto ao público considera que o registro não conseguirá reproduzir a ação, nem tampouco o efeito cartático que a experiência presencial proporcionou. Uma foto do trabalho pode exibir a trama visual desenvolvida, é o caso das fotografias do seu trabalho, junto à exposição “Terra Comunal”, de Marina Abramović no SESC Pompeia, em São Paulo, que são "uma visualidade épica de destruição (...) que é um pouco banal também” (IANÊS, 2017, p. 10). Sobretudo, em relação às outras ações de Ianês, esse artista acredita que as imagens sozinhas não suprem a potência de suas performances, seria fundamental vivenciar para experimentar e compreender seu trabalho. Essas especulações levam o performer a questionar:

\footnotetext{
Será que existe de fato uma necessidade de preservação? Que seja totalmente desvinculada do contexto da experiência deste trabalho? Isso é uma pergunta que eu me coloco. (...) a gente vive, sei lá, no período da hiperdocumentação. Tudo tem que ser documentado, tudo tem que ser registrado, as coisas mais estúpidas do mundo a gente têm que fazer selfie para mostrar, para tornar público, para arquivar, para mostrar (...). Mas, se não é mais interessante a gente dar valor ao efêmero, ao invisível, ao que desaparece? Ao que a gente não consegue apontar o dedo, ao que não tem forma, ao que se dá entre duas pessoas, que não sou nem eu e nem a outra pessoa, um diálogo que vai acabar no ar, que vai acabar no tempo? (IANÊS, 2017, p. 10-11).
}

Ianês (2017) completa ratificando que fotos e vídeos de suas ações são documentos, têm restrito caráter histórico para pesquisa e não possui valor comercial.

Nesse sentido, Alcimar Frazão (2016) vê a imagem como peça de relevância pelo espaço que abre para discussão dos trabalhos de ação ao vivo por favorecer a prorrogação do tempo da obra que, por vezes, aconteceu em um único momento. Frazão, no entanto, é 
convicto que é apenas um registro e não a obra, e traça um paralelo com uma foto de uma pintura, que auxilia o estudo, o debate do trabalho e sua permanência no tempo, mas sempre será diferente do contato direto com a obra original.

Por outro lado, é importante o registro pela importância da discussão do trabalho, a obra não pode estar limitada a um único e exclusivo momento em que aconteceu. Assim, o registro favorece a permanência no tempo e é essencial lapidar estratégias para esses registros, tendo sempre em vista que se trata de um registro. Um paralelo ao registro da performance pode ser encontrado nos livros de arte, que fotografam obras como pinturas e esculturas, instrumentos de apreciação e pesquisa, mas que não substutuem a expeiriência do contato presencial, do diálogo direto com o receptor. Ainda assim, a foto pode contribuir para discutir essa pintura e sua devida permanência do tempo (FRAZÃO, 2016, p.12).

Alguns artistas parecem estar em sintonia com Frazão (2016) e não permitem registro de suas ações, "o que se verifica com o trabalho desenvolvido pelo artista Tino Sehgal que impede, proíbe os registros em fotos e vídeo de suas performances, ratificando que esses procedimentos não são os únicos modos de perpetuar essas ações" (ALVES, 2016, p. 7).

Figura 32 - Exposição Terra Comunal. "The house with the ocean view" ("A casa com vista para o mar")", Marina Abramović, 2002
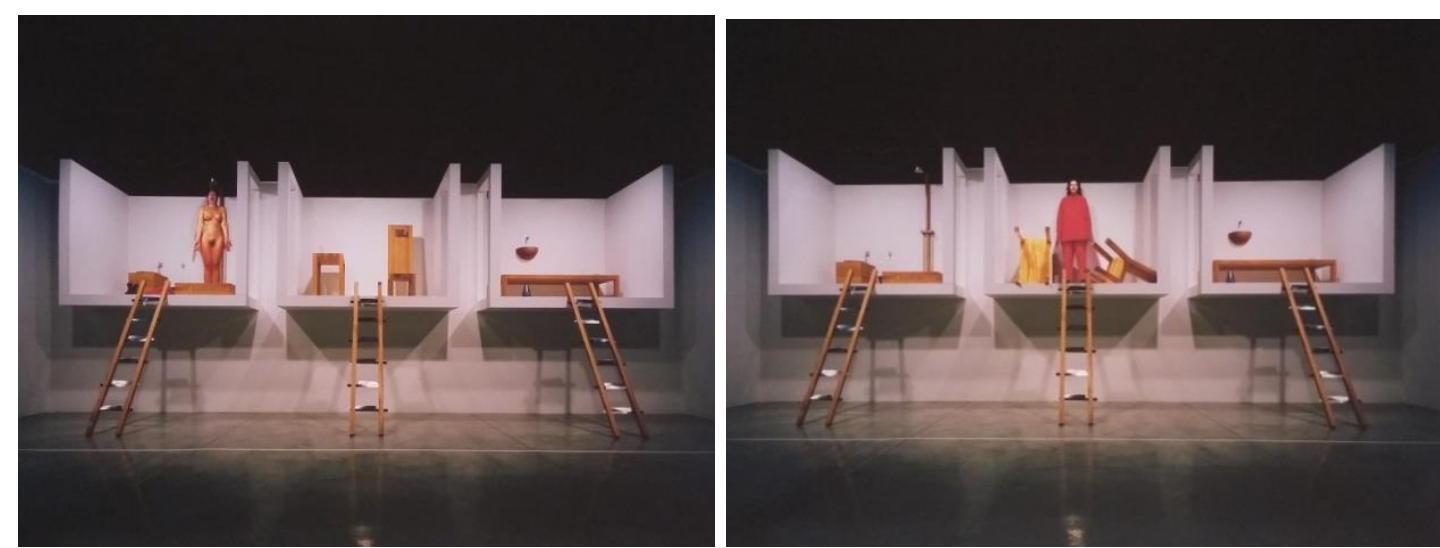

Fonte: ALVES (2016) Exposição Terra Comunal - Marina Abramović +MAI (s.d.).

Disponível em: <http://dudugontijo.com/terra-comunal-marina-abramovic-mai>. Acesso em: 7 jan. 2018.

Alves (2016) acredita que o vídeo e a fotografia não são os únicos meios de divulgação das ações. Ele relata uma experiência que o fez refletir sobre outros caminhos de propagação de performances, como a oralidade que permite ecoar o trabalho pela vertente da história oral, já que as performances são mais que imagens que se recriam

\footnotetext{
${ }^{26}$ Marina Abramović permaneceu, por 12 dias, em três cômodos suspensos de frente para a rua. Sem se alimentar e em silêncio. O público podia vê-la dormindo, tomando banho, indo ao banheiro e meditando.
} 
cada vez que são contadas, não se reduzindo às imagens e registros. Segundo Alves (2016), Sehgal optou por esse meio expressivo que é menos comumente aceito pelo sistema comercial.

Eu soube da exposição do Tino Sehgal na Pinacoteca, eu demorei para ir, quando eu fui tinha acabado e eu fui perguntar para um segurança: poxa, cadê as performances do Tino Sehgal, que estavam aqui? Ah! acabou, (...) o segurança era o que ficava fazendo polichinelo e ele começou a me contar, porque quem executava era o segurança, então eu conversei com o performer (CAUÊ, 2016, p. 7).

Outro aspecto que Alves pondera consiste no fato de a fotografia ter sua própria gramática de produção (enquadramento, luz e aparato tecnológico) que nem sempre está em sincronia com a ação, portanto, é fundamental ter outras estratégias. Dentre essas, estão os depoimentos de quem presenciou a ação, pois cada performance terá seu legado particular, bem como seu modo de perpetuar sua história. É evidente que caminhos como a oralidade são menos precisos e mais flutuantes que os registros por meio de imagens, ao mesmo tempo não existem garantias que a fotografia seja o caminho mais concreto para essa demanda.

A arte se transforma com o tempo, a reencenação, aquilo vivo, os depoimentos e histórias orais também vão transformando, vão fazendo, então é importante entender essa outra dimensão da performance, da experiência que ela proporciona e que ultrapassa o campo da imagem (ALVES, 2016, p. 8).

Em 2016, Marcos Gallon, diretor da Mostra "Verbo", afirmou que a Galeria ${ }^{27}$ não possui acervo de performance, apenas arquivos fotográficos e videográficos de todas as performances executadas. Apontou ainda ter convicção que, no devir, essa documentação será material de pesquisa já que cada reapresentação de uma performance carregará outras questões e significados, não sendo igual a original. Pois, segundo Gallon (2016, p. 9), o momento é único, logo, esse arquivo será instrumento de investigação acerca do "cenário das artes visuais e da performance em São Paulo, nas duas primeiras décadas do século XXI”. Por outro lado, a massa potente dessa ação só afeta as pessoas que estiveram presentes no tempo/espaço em que ela ocorreu.

Outra interface do registro fotográfico em performance, que está intimamente ligada ao viés comercial, é a multiplicação, tradicional na gravura como objeto de arte (recebendo numeração a cada cópia de modo que quanto menor o número, maior seu valor financeiro). $\mathrm{O}$ mesmo ocorre com a fotografia que trabalha com edição de peças reprodutíveis. Essa abordagem é antagônica à performance que a cada encenação será

\footnotetext{
${ }^{27}$ Conforme consta no site da instituição: "A Galeria Vermelho criou a mostra de performance arte VERBO, em 2005, porque, para muitos de seus artistas, lidar com o corpo é essencial" (GALERIA VERMELHO, s.d.).
} 
outra obra, norteada por outro contexto e, possivelmente, por outro público (GALLON, 2016, p. 10). O registro fotográfico da performance, que congela um momento da ação, traz atributos. Tal qual o DNA é um recurso para registro e pesquisa, a fotografia pode ser um produto, uma obra em si, mas não carrega toda a potência da ação ao vivo.

Naira Ciotti (2017, p. 4) destaca que, no curso do tempo, alguns acervos trabalharam com fotografias de performances, "a gente pode pensar até no Brasil, mesmo Lygia Clark, Hélio Oiticica com a foto da baba antropofágica, por exemplo, é um documento de performance bem interessante". Segundo ela, historicamente, assim como na arte conceitual, fotos e vídeos são objetos palpáveis comerciáveis que, simultaneamente, representam fontes de pesquisa. Contudo, Ciotti $(2017$, p. 4) ressalta que isso difere do que ela denomina por fúria de documentação dos celulares, até porque as fotos de performance são notoriamente dirigidas pelos artistas ou pelo criador que, intencionalmente, "inscreve o corpo na criação" como o fazia a arte conceitual.

A artista, em uma palestra em 2016 no SESC, teve a oportunidade de apresentar algumas fotos da performer Francesca Woodman, que teve uma vida curta. Sua proposta de trabalho utilizava a plataforma fotografia e, nessa experiência, pode observar a performatividade intrínseca nas imagens que transcende o objeto fotografia.

O Verdadeiro Artista que está soltando umas gotinhas de água pela boca. A gente vê que naquelas fotos tem alguma coisa para além do meramente fotográfico, se é que eu posso falar assim, me perdoem, mas eu não estou querendo dizer que a fotografia seja menor, estou querendo dizer, que tem um hibridismo de novo aí (CIOTTI, 2017, p. 8).

Figura 33 - Baba antropofágica, de Lygia Clark. 2009

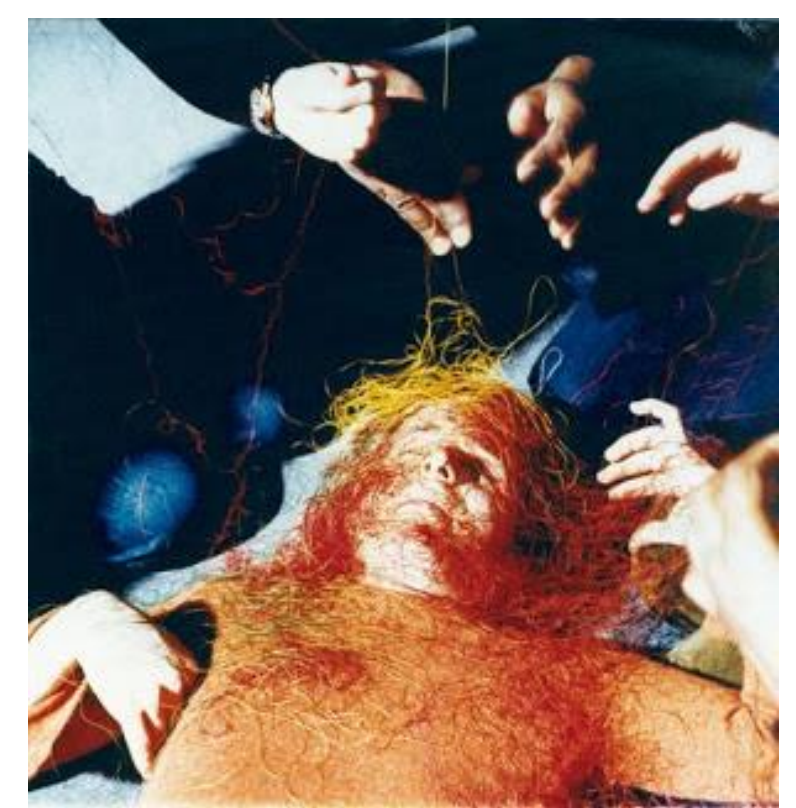

Fonte: http://babaantropofagica.blogspot.com.br/ 
Nos anos 60, as ações performáticas foram uma das responsáveis pelo rompimento da aura da obra de arte, da noção dos atributos dos objetos de arte e da sua devida fruição, de acordo com Fernanda Pitta (2016). A recusa em registrar ação, bem como em permitir que se transformasse em objeto, marcou a trajetória dessa linguagem, em contrapartida com "o aspecto imaterial da presença, daquela experiência específica irredutível de estar diante do artista, ou agindo, atuando, performando junto com o artista, ou observando o artista performar" (PITTA, 2016, p.12).

Como curadora, Pitta (2016) entende que os registros têm caráter pedagógico junto ao público que não está acostumado com esse segmento artístico. O registro serve, portanto, como uma ferramenta de informação do que foi presenciado, mas Pitta (2016, p. 12) salienta que é um documento, não o próprio trabalho: “digamos assim, essa espécie de vazio que está entre a experiência, e a memória dessa experiência, (...), o registro dessa experiência, me parece uma solução que garante a memória desse tipo de trabalho imaterial".

Essas demandas estão imbricadas na obra tombada na Pinacoteca de São Paulo, de Maurício Ianês, que, claramente, deseja garantir o estatuto documental de seu trabalho, distintamente diferenciado da ação. "Outros artistas são, não vou dizer mais radicais, enfim, para evidenciar mesmo a importância daquele momento, do lugar específico, da experiência do aqui e agora que é característica da performance, recusam todo e qualquer tipo de registro" (PITTA, 2017, p.12).

Há obras cujo formato é fotográfico, mas também possuem caráter performático. Segundo Pitta (2017), a Pinacoteca tem em seu acervo trabalhos como os de Amilcar Packer, performance registrada em fotografia que, para o artista, é o resultado de seu trabalho. Essas fotos pertencem à categoria fotografia dentro do acervo da Pinacoteca de São Paulo e Pitta (2017, p. 7) coloca que "respeita muito a forma como o artista entende, veicula seu trabalho, bem como o nomeia, dentro das categorias da produção artística".

A fotografia é um fenômeno que adentra o universo das artes, mas é uma ferramenta utilizada também como recurso de preservação da memória. É muito comum as pessoas congelarem momentos importantes e significativos de suas vidas por meio de fotografias. Em um passado próximo, os álbuns impressos e temáticos eram presença importante no cotidiano familiar. As cerimônias, mesmo nos dias atuais da era digital, utilizam o recurso da fotografia para perpetuar os momentos significativos. As imagens têm efeito cartático e narrativo e são presenças constantes no dia a dia das pessoas.

Um exemplo são as famosas selfies que estão presentes nas redes sociais e registram, em tempo integral, tudo a todo o tempo. Os museus encontram nas fotos 
objetos artísticos e registros de atividades temporais e de ações com a presença corporal, que incorporam em seus acervos, arquivos e documentos, repertórios expressivos do tecido artístico de linguagens como a performance. O momento registrado em foto é congelado, propiciando ao leitor dialogar, relacionar e traduzir sensações que, a cada contato com a imagem, trazem um novo discurso que se conecta com o repertório do observador. Um advento interessante nos museus modernos e contemporâneos são as obras interativas, porém, devido ao caráter da instituição de conservar e salvaguardar as obras, em geral, não se permite o manuseio das mesmas, mesmo com orientação de alguns artistas solicitando a participação do público. A sensação, ao contemplar essas obras, é similar ao registro fotográfico, que congela uma faceta da obra, apenas um ângulo.

Conforme Laura Lima (2017), alguns artistas preferem que suas obras não sejam fotografadas porque o cerne de seus trabalhos tem essa abordagem. Eles não desejam materializar as ações, reter ou objetificar, nem mesmo em catálogos e programas. Apenas as fotografias servem como elementos da descrição, parte integrante da instrução. Contudo, Laura não se opõe ao registro fotográfico de suas ações.

Efetivamente, Juliana Moraes (2016) acredita que fotos, bem como vídeos, são registros essenciais à pesquisa. Isso se torna evidente, principalmente nos anos 70, pois algumas performances, até nossos dias, são visitadas por meio desses registros, mesmo porque algumas ações foram únicas e o que restou, além de depoimentos, registros jornalísticos e de divulgação, são fotos e/ou vídeos que remetem àquele momento.

Vale observar que fotos, contudo, podem causar tensionamento, como se pode observar nos trabalhos de Maurício Ianês, que estabelece narrativas preponderantes e íntimas com seu público. Para Ianês (2017), os registros são representações pálidas da ação, não traduzem o impacto da vivência presencial. Moraes (2016) lembra que ao ver as fotos da performance "Como depender da boa vontade de estranhos", de Maurício Ianês, presente na $28^{a}$ Bienal de São Paulo (que ocorreu em 2008), teve uma ideia daquele trabalho, mas teve outra percepção ao assistir uma entrevista de Ianês descrevendo o mesmo trabalho, relatando como "as pessoas tinham que fazer para entrar com comida e toda a negociação dele [do artista] com a instituição (...). Para mim [Moraes], modificou a memória do evento, que eu tinha a partir das fotografias" (MORAES, 2016, p. 12). Ela percebeu que as fotos que lhe foram apresentadas não foram suficientes para a compreensão nem para uma leitura mais profunda do trabalho do artista. 
Figura 34 - Performance "Como depender da boa vontade de estranhos", de Maurício Ianês, 2008

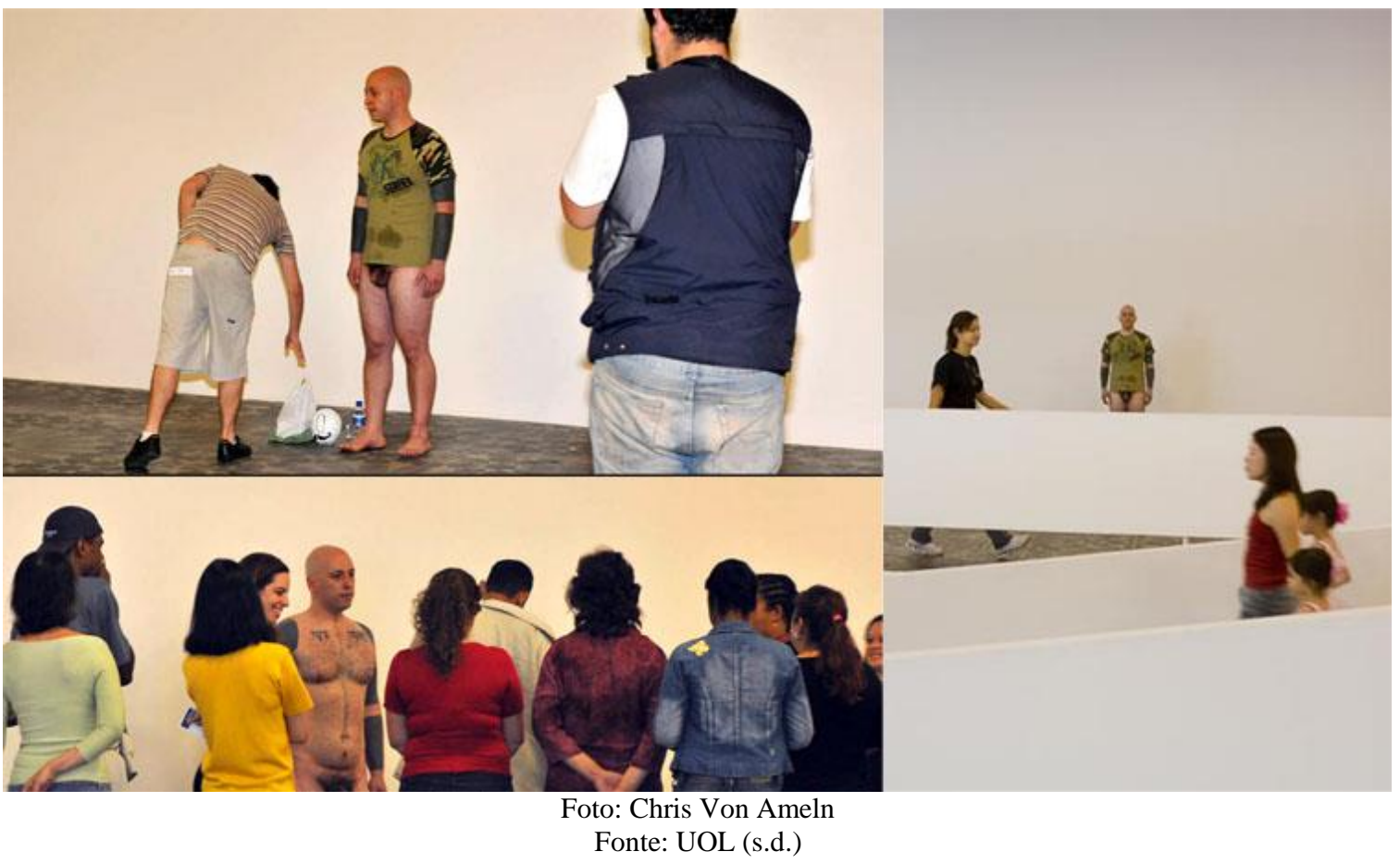

Importante ressaltar que fotografias possuem efeito catártico e, sobretudo, são ferramentas utilizadas para pesquisas e normalmente encontradas nos arquivos junto às descrições e orientações de muitas performances. Além de serem peças presentes nos catálogos de divulgação dos trabalhos, em diversos acervos, são por vezes imagens de amadores, com a tarefa de traduzir o diálogo e a interação da obra com o público, os famosos selfies full time, presentes em todos os espaços contemporâneos, ansiosos em documentar e salvaguardar tudo o que os olhos percebem, bem como integrar o autor do registro com a obra apresentada.

\subsection{VÍDEO}

Alguns artistas de performances estão lidando com a questão de como registrar o material e transformá-lo em acervo, já que a linguagem está no campo da imaterialidade e as instituições tradicionalmente operam com objetos. Exemplo de registro pode ser encontrado nos trabalhos de Marina Abramović, que fotografou e filmou suas ações performáticas, e hoje é possível apreciar e pesquisar essas obras, por meio desses registros, como ocorreu na exposição "Terra Comunal".

O que tem sido feito é o registro em vídeo fundamentalmente, hoje já tem tecnologia acessível para isto. $\mathrm{O}$ que as instituições fazem é lidar com esse acervo. Esse é um segundo trabalho, porque a performance propriamente dita é a ação cênica, que acontece no tempo e espaço, com data, com período (FRAZÃO, 2016, p. 7). 
O cinema quando entrou em cena mudou o suporte de forma radical, abriu horizontes e projetou, até os dias atuais, possibilidades de plataformas que parecem acompanhar o ritmo da sociedade contemporânea. O mais importante é que possibilita o registro de pessoas e objetos em movimento. Seus desdobramentos, quanto aos aspectos referentes a produção, reprodução e circulação dos trabalhos artísticos são inúmeros, podendo suscitar várias leituras e significados principalmente em contato com o público. Cada vez mais, espaços alternativos surgem, e as instituições de arte, junto a crítica que ora se apropria, ora contesta, bem como os espaços públicos, recebem as mais diversas obras de arte.

O cinema que narra e escreve por meio da luz, que registra o momento no qual o ato acontece com uma estética própria, com ferramentas específicas, oportuniza a reprodução, já que possibilita sua exibição para um grande público simultaneamente, em locais diferentes. Talvez por isso, essa forma de arte, em sua trajetória, vem demonstrando ter participação direta na vida da sociedade. A sua utilização como ferramenta de suporte, registro, ou mesmo como elemento estético em parceria com outras artes, está cada vez mais presente. Seu uso como documentação de performance pode ampliar o acesso e entendimento ao público.

Um exemplo efetivo dos atributos do vídeo em performance, que corroborou para ampliar o entendimento da ação do performer, ficou evidenciado em "Monumentos Temporários", do artista Fyodor Pavlov-Andreevich, no Museu de Arte Contemporânea de São Paulo (2017), que foi pré-estreado em Moscou, no Centro de Arte Contemporânea Winzavod. Fyodor, com o desejo de evidenciar o trabalho escravo na contemporaneidade, que ocorre em espaços públicos e simbólicos, por meio de ações reais, apresentou aos visitantes, por fotos e vídeos, instalação que oportunizava uma experiência individual e íntima com a ação. 
Figura 35 - "Exposição Monumentos Temporários", Fyodor Pavlov-Andreevich, MAC-SP, 2017 (espaço de exibição de vídeos)

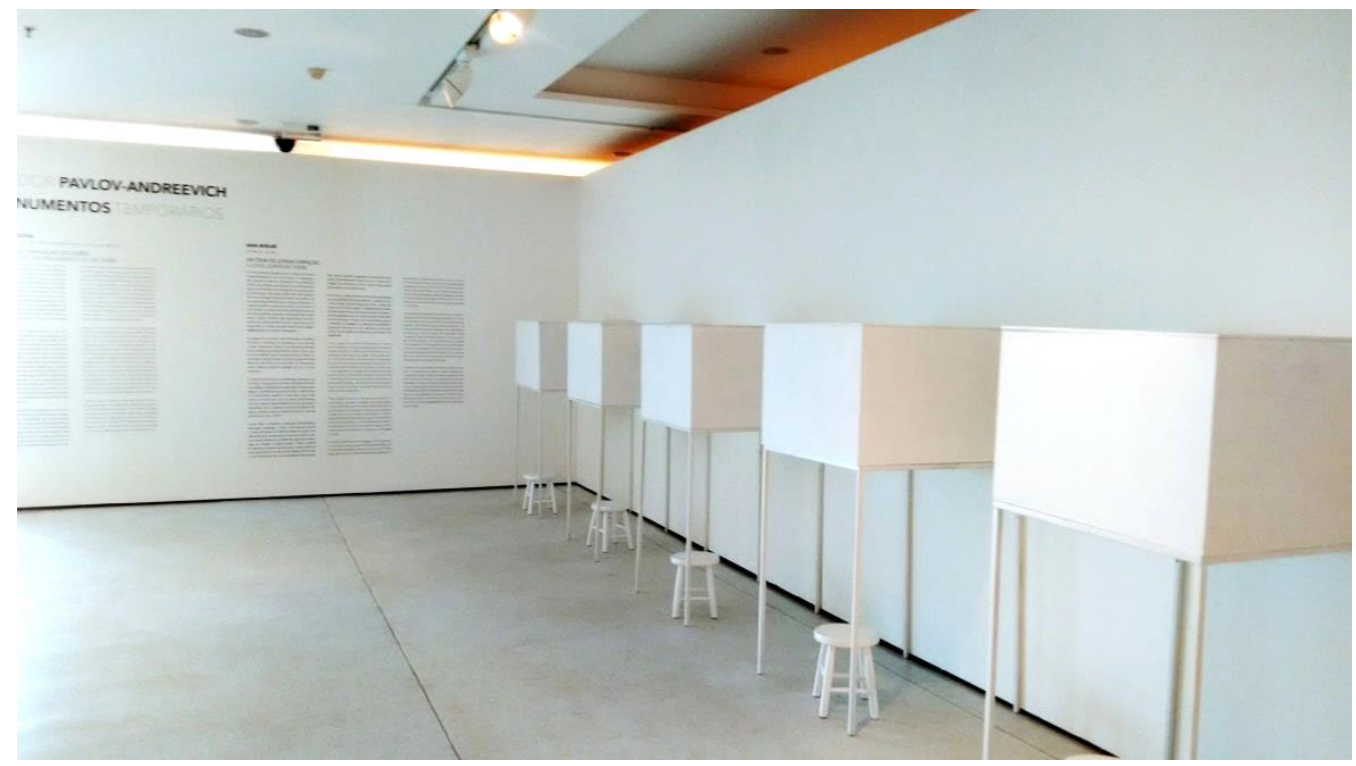

Foto: Joseane Alves Ferreira, 2017

Figura 36 - "Exposição Monumentos Temporários", Fyodor Pavlov-Andreevich, MAC-SP, 2017

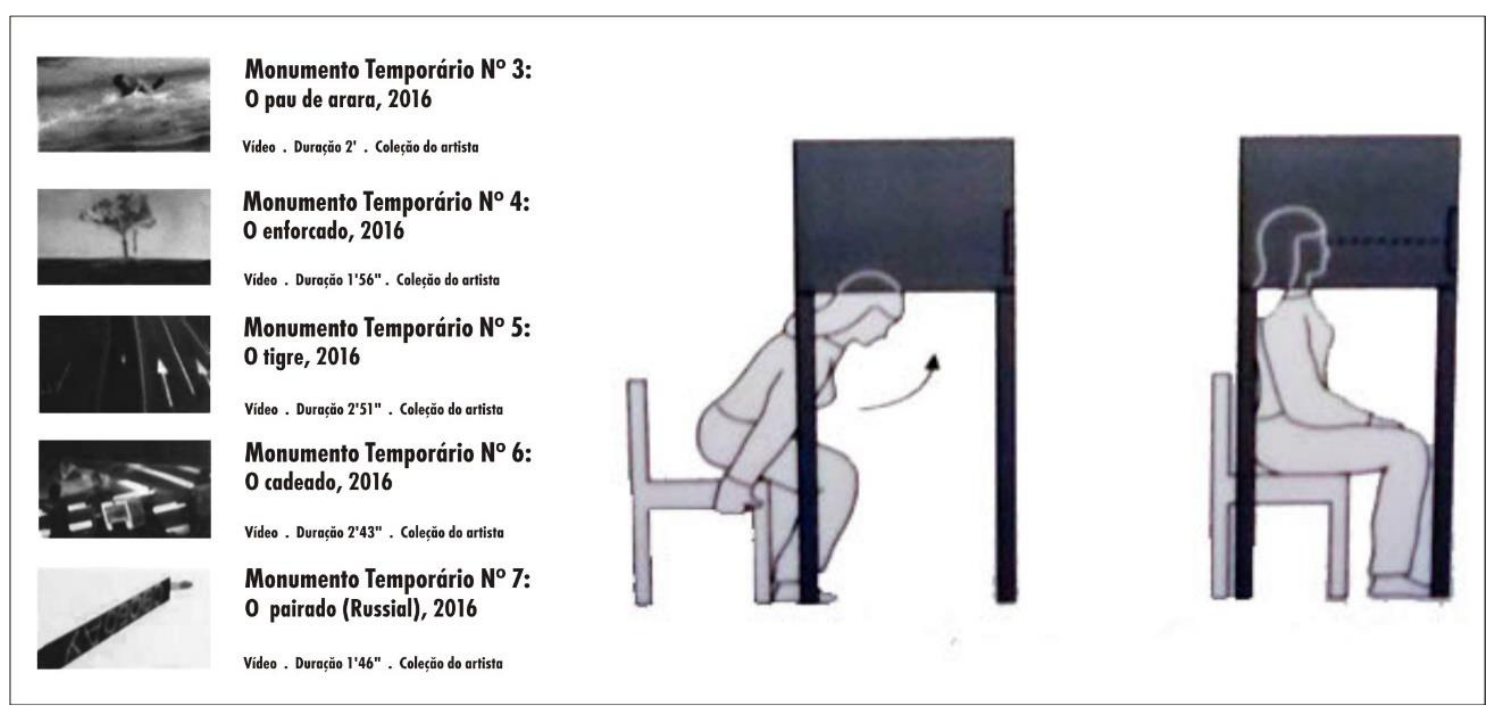

Foto-montagem: Joseane Alves Ferreira, 2017.

$\mathrm{O}$ visitante se sentava em um pequeno banco, introduzia sua cabeça em um buraco circular, na base de uma pequena caixa, onde o vídeo era projetado. $\mathrm{O}$ artista fez suas performances sozinho, durante sete horas cada. O vídeo apresentava alguns minutos somente, mas, devido ao posicionamento do corpo do visitantee ao isolamento do público, a ação do artista desafiava o visitante a questionar situações de sofrimento e castigos, que são impostos a personagens comuns da sociedade contemporânea. O performer utilizou seu corpo, empoderando-o de torturas e provações que perpetuam atos historicamente utilizados no passado, mais especificamente no período de escravidão. Fyodor, de origem russa, expandiu seus horizontes, apontou situações comuns entre seu país de origem e o Brasil, indicando que, em qualquer sociedade, ocorre o privilégio de 
uns em detrimento de outros. Esses vídeos da exposição foram determinantes para o debate e o diálogo com o público que não vivenciou a ação.

Existem obras pensadas para a plataforma vídeo o que é mais um registro que aponta a diversidade que essa linguagem acabou impondo no século XX. A vídeo-dança é retrato dessa dinâmica, pois a dança que aconteceu ao vivo, por meio do corpo processado e coreografado para o vídeo, se desdobrou em outro produto. O mesmo acontece com artistas que, em seu processo criativo no campo das artes visuais, encontram um canal pela objetiva da câmera para realizar seu trabalho e dialogar com o público. Esses processos compreendem criar para plataforma vídeo, e o público terá contato somente com o resultado registrado, não com a ação em si; o receptor vivenviará a obra, em outro espaço e tempo, mas diretamente conectado ao conteúdo cujo direcionamento foi dado pela câmera (GALLON, 2016).

Voltando ao universo da dança, bem como o teatro, os acervos são ligados à museologia (MORAES, 2016), como estratégias para futuras gerações conhecerem e apreciarem as presenças corporais, no intuito de salvaguarda das obras que, a priori, foram apresentadas ao vivo. Evidentemente, no teatro, existe o suporte do texto, mas é na ação presente do corpo que a obra se faz. Nesse cenário, o vídeo, devido a sua verossimilhança, é tratado como ferramenta pertinente e como objeto de pesquisa e fruição dessas linguagens. No entanto, o vídeo não é imparcial, carrega consigo o olhar de quem o manipulou e captou o momento, bem como a qualidade do equipamento, os planos e enquadramentos, a iluminação, a edição e até mesmo a opção do que está dentro ou fora da imagem. São escolhas que interferem diretamente no produto final videográfico, que sempre se diferenciará da apresentação, porque o olhar da câmera, necessariamente, não é o mesmo do artista, nem do público, sobre a mesma ação.

Segundo Moraes (2016), como a gravura que possibilita a reprodução, através de uma matriz, e o artista determina uma quantidade de reprodução, restringindo as cópias e valorando comercialmente seu trabalho, alguns performers também limitam a venda dos vídeos, mas, com o advento da internet e da plataforma de vídeos YouTube, ferramentas de acesso amplamente difundido na sociedade atual, Moraes (2016) considera essa limitação difícil de ser controlada, porque a gravura traz impressa a data e o número estampado na obra e o mesmo não acontece com o vídeo.

Uma referência emblemática de registro em vídeo é do artista norte-americano, Chris Burden (1946-2015), com a performance "Shoot", de 1971, que aconteceu dentro de uma galeria, na qual um assistente portava um rifle, em referência à indústria das armas e atira no braço de Burden, como alusão aos traumatizados que voltaram da Guerra 
do Vietnã. A manifestação era uma prerrogativa aos jovens que eram alvos de disparos. Sua ideia inicial era receber uma bala de raspão, com algumas gotas de sangue, uma metáfora da violência, revelando a situação de muitos jovens de idade similar à do artista, contudo a bala penetrou em seu braço esquerdo, resultando em meses de terapia. Esse fato teve um desdobramento inusitado: "o artista, ao contratar alguém para lhe dar um tiro no braço, consegue atiçar a curiosidade de quem adquire fotos desse momento, despertando o modismo" (VALITERATURA, 2013), e, segundo Moraes (2016), essa performance é assistida até nossos dias. Apesar da sua curta duração, o vídeo resiste ao tempo.

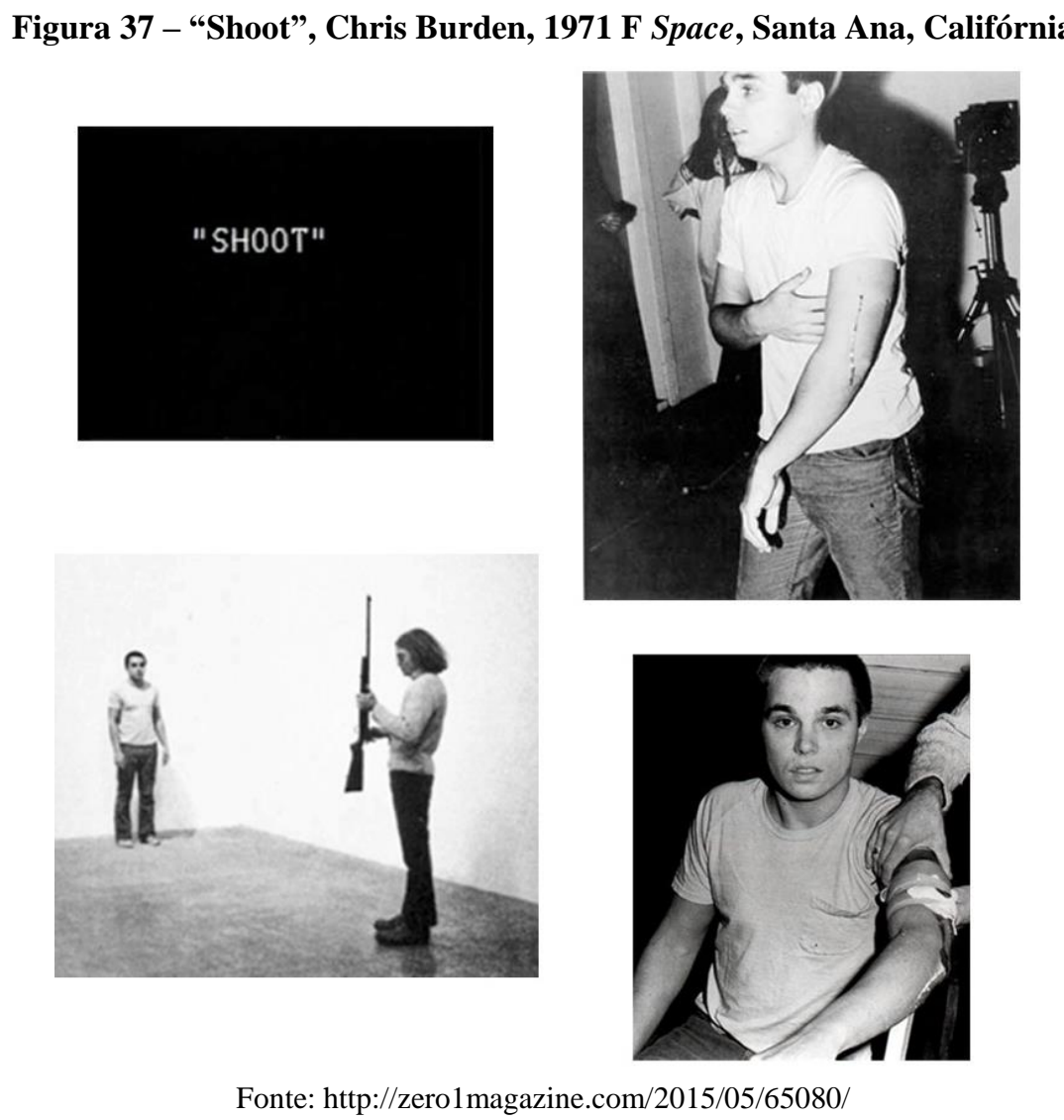

Outro exemplo relevante é a obra "Divisor" (1968), de Lygia Pape, na qual se encontram alguns vídeos que registraram a performance e cada qual possui ângulos diferenciados, mesmo porque a obra foi reperformada algumas vezes, desde sua estreia no período de ditadura no Brasil, no momento que se instalou o Decreto AI- $5^{28}$. Segundo sua filha Paula Pape, a performance consistia em vestir mais de 100 pessoas com um

\footnotetext{
${ }^{28}$ O Ato Institucional $\mathrm{n}^{\circ} 5$, baixado em 13 de dezembro de 1968, durante o governo do General Costa e Silva, foi a expressão mais acabada da ditadura militar brasileira (1968-1985). Vigorou até dezembro de 1978 e produziu um elenco de ações arbitrárias de efeitos duradouros. Definiu o momento mais duro do regime, dando poder de execução aos governantes para punir arbitrariamente os que fossem inimigos do regime como tal considerados (VENTURA, 1988)
} 
lençol branco com várias fendas nas quais cada pessoa colocava sua cabeça, expondo-a e ocultando seu corpo, fazendo movimentos variados que os participantes não conseguiam visualizar somente as cabeças de seus pares. Essa imagem de cabeças cortadas, quando foi criada por Pape, tinha um caráter político diretamente ligada ao Decreto e sua repercussão extremamente repressora.

Figura 38 - "Divisor", Lygia Pape, 1968, no Museo Reina Sofía, em2011

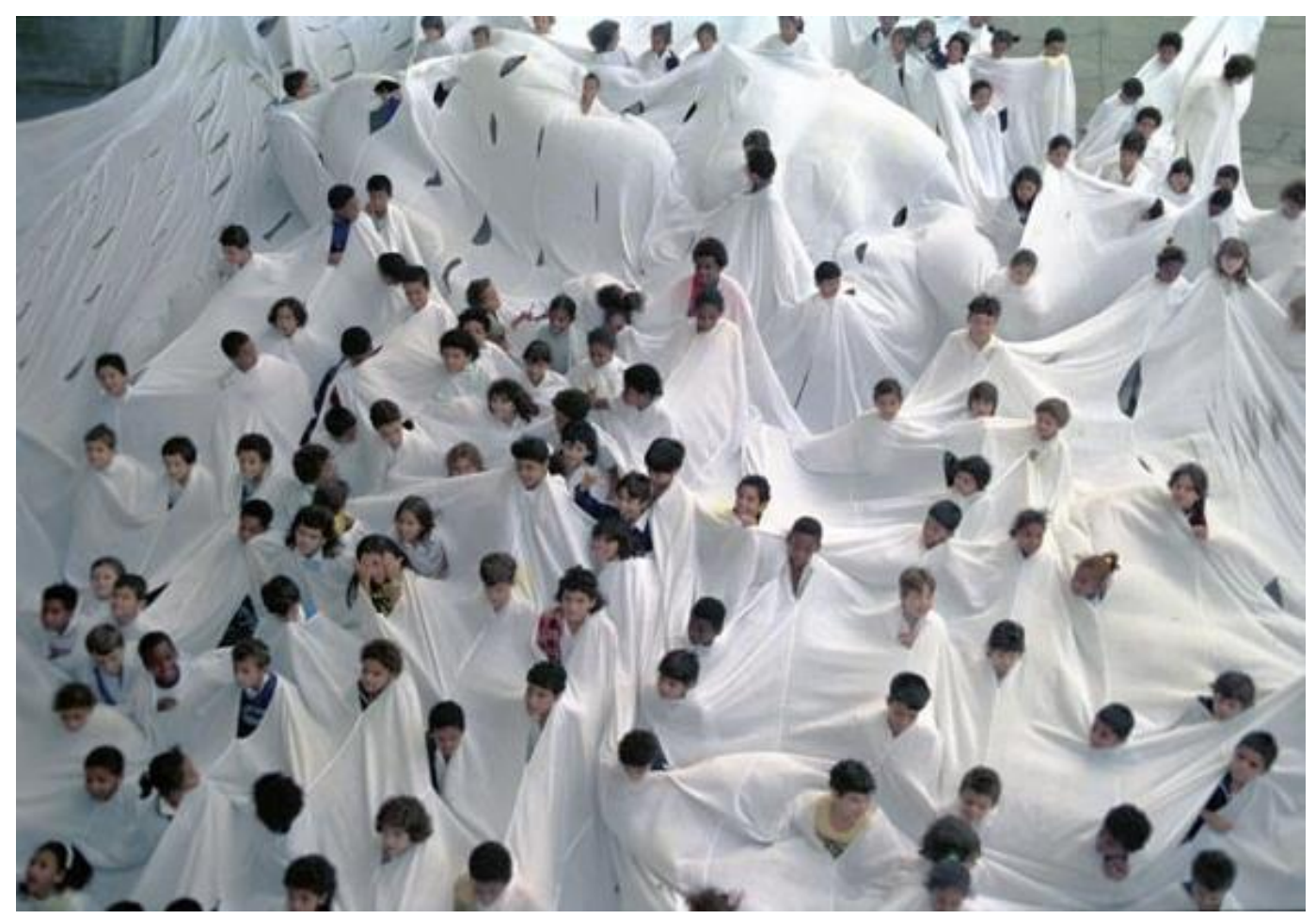

Fonte: http://www.museoreinasofia.es/en/actividades/divisor-lygia-pape-performance, 2011

A obra foi reperformada no Museu de Arte Moderna do Rio (2010) e participou da abertura da 29a Bienal de São Paulo (2010) com a participação de 200 pessoas que se inscreveram antecipadamente. Na ocasião, tempos posteriores à ditadura, essa imagem lembrou um mar, com suas ondas, como descreveu a filha de Pape. "É uma questão política, mas parece o mar, é um poema visual" (MARTÍ, 2010). A obra "Divisor" continuou a ser reperformada como desejava sua criadora: "Queria fazer uma obra coletiva, que as pessoas pudessem repetir sem que eu estivesse presente", disse na época. “O processo só pode ser definido quando o artista desaparecer" (MARTÍ, 2010). Na encenação feita no Museo Reina Sofía (2011), que também foi registrada em vídeo, pôdese constatar como essa obra emblemática de Pape, por meio de seus registros em vídeo, continua exercendo impacto com o passar dos anos para quem assiste, bem como são tratados os registros videográficos efetuados em épocas e com autores diferentes como referências para reperformar a obra, permitindo leituras diversas da mesma ação sem perder a essência autoral de Pape que propôs romper distância entre obra e público. 
Uma particularidade com relação ao vídeo é possibilitar a avaliação de performances via "editais que usam essa plataforma para avaliar as ações, enviadas pelos artistas. Em alguns casos, os vídeos são muito bons e a encenação nem tanto" (MORAES, 2016, p. 12). Mas a preocupação em registrar essa expressão artística no Brasil é recente, dificultando a vida dos pesquisadores acadêmicos que necessitam desse material para estudos.

Nos Estados Unidos, historicamente, têm-se registrado essas ações devido à preocupação com os artistas, encorajando os pesquisadores brasileiros a darem preferência para projetos com artistas fora das fronteiras nacionais, notadamente os norteamericanos pela disponibilidade de material de pesquisa.

O Tate Modern, museu de arte moderna sediado em Londres, adota como política institucional quanto à plataforma vídeo a metodologia de criar uma matriz de preservação, não compactada, que facilita a migração para futuras reproduções com margem confiável de qualidade. Esse processo é renovado a cada cinco anos, minimizando alterações no original. Esse procedimento demanda conhecimento tecnológico e aprofundamento nas novas tendências de ponta. Outro aspecto relevante refere-se às práticas dos artistas que, devido às facilidades tecnológicas, conseguem editar suas obras em equipamentos pessoais. $\mathrm{O}$ museu utiliza equipamentos como servidores para armazenamento de dados.

O Centro Universitário Belas Artes de São Paulo (fundado em 1925), com quase 100 anos de existência, atua no universo das artes e vem norteando muitos alunos que tem como eixo central o registro em vídeo de suas performances e "chegam a filmar com quatro câmeras diferentes para garantir o registro", explica Juliana Moraes (2016, p.12).

Outro fator relevante quando se trata de filme é a conservação. Os que utilizaram película, por exemplo, requerem laboratório especializado e, dependendo do formato (8mm, $16 \mathrm{~mm}$ ou $35 \mathrm{~mm})$ precisam garantir a qualidade das filmagens, não se tratando de uma tarefa simples, tanto no que se refere ao arquivo, quanto à exibição, pois, a cada projeção, a película vai deteriorando e isso exige substituição da fita constantemente. Quando o original é de propriedade do artista, o Tate Modern utiliza o recurso do interpositivo, técnica eficaz para verificação de cor e contraste. O museu, que trabalha com várias linguagens artísticas, prima pela excelência e, se necessário, solicita cópia de referência junto ao criador. Nesse contexto, dependendo da tecnologia de captura utilizada pelo artista, o diálogo entre ambos é primordial, seja por entrevista ou por critérios de conservação, principalmente na primeira instalação. 
Incorporar filmes como acervo pressupõe sua exibição e o Tate Modern, consciente da diversidade de elementos que implicam uma boa exibição (como filtro, lâmpada e projetor), aproxima seus colaboradores com fabricantes especializados, com a perspectiva de apresentar imagens de qualidade. Quando a performance finaliza seu projeto nessa plataforma ou é apresentada ao público nesse formato, essas preocupações e cuidados são sinônimos de excelência com a obra de arte na sua exposição e sua interface com o público (TATE MODERN, 2004).

Instituições que trabalham com esses materiais têm uma tarefa árdua e constante, pois necessitam de políticas pertinentes de conservação e exibição, sem perder a essência da obra e o olhar do artista. Por isso, é comum o diálogo entre a instituição e o artista que por vezes autoriza nas exposições o formato vídeo como obra ou até mesmo como referência e orientação para reperformar a obra.

A Pinacoteca de São Paulo, nesse sentido, ao adquirir a obra de Ianês, considerou importante solicitar um vídeo descritivo da performance, com o processo e a orientação dos artistas, que foi gravado no interior da instituição, uma vez que a Pinacoteca é integrante de uma rede internacional de conservação entre museus que utiliza da troca de informações. Segundo Ianês (2017), para se atender à demanda de arte contemporânea, as instituições devem ampliar o universo de bens culturais e artísticos, isso implica em incorporar nos seus acervos instalações, performances, obras de caráter imaterial, encenações, nas quais o corpo é a matéria prima.

Nesse mesmo prisma, a Pinacoteca de São Paulo, após receber a obra de Ianês, solicitou ao artista e a Marcos Gallon, da Galeria Vermelho, que mediou a comercialização da obra, para adicionar mais informações e detalhes referentes à obra, por meio de entrevista, resultando em um vídeo que foi agregado à documentação. Essa gravação atende às diretrizes da International Network for the Conservation of Contemporary Art [INCCA], base de dados acerca de conservação de arte contemporânea, que fornece informações desse tipo de registro entre as instituições interessadas. Para agregar conhecimento, estavam presentes o Núcleo de Conservação e Restauro, a Curadoria e o Núcleo de Acervo Museológico, ou seja, todos os responsáveis pela catalogação. A partir dessa abordagem, o artista se propôs a elaborar um vídeo com orientações, além das textuais, já que a performance exige "certo preparo, uma questão de respiração, (...) de preparação física", (IANÊS, 2016, p. 6), que implementou o corpo de informações principalmente quanto a sua preservação.

Já a Galeria Vermelho, afirma Gallon (2016, p. 3), que comercializa performances, não possui acervo, apenas patrimônio documental de todos os trabalhos da 
Mostra Verbo, desde sua primeira edição (2005), que são capturas na íntegra na plataforma vídeo, completando cerca de 3.000 ações. Dentre as 11 edições da Mostra, esses materiais são de caráter de divulgação e pesquisa para estudiosos e artistas no "campo da performance".

Uma experiência satisfatória de registro videográfico ocorreu com o performer Cuquinha em uma de suas ações denominada "Filtro" (2014), na qual um grupo de visitantes tinham que passar entre alguns policiais fixos em um determinado espaço, os visitantes tinham que esbarrar e tocar os corpos dos policiais. A experiência foi gravada com duas câmeras, uma frontal, que gravava os rostos e expressões, uma espécie de câmera subjetiva, traduzindo o efeito psicológico da ação, e outra que ficava na parte superior, visão aérea, gravando o movimento dos corpos, a geografia e a coreografia.

Figura 39 - Performance: "Filtro", Lorival Cuquinha, 2014

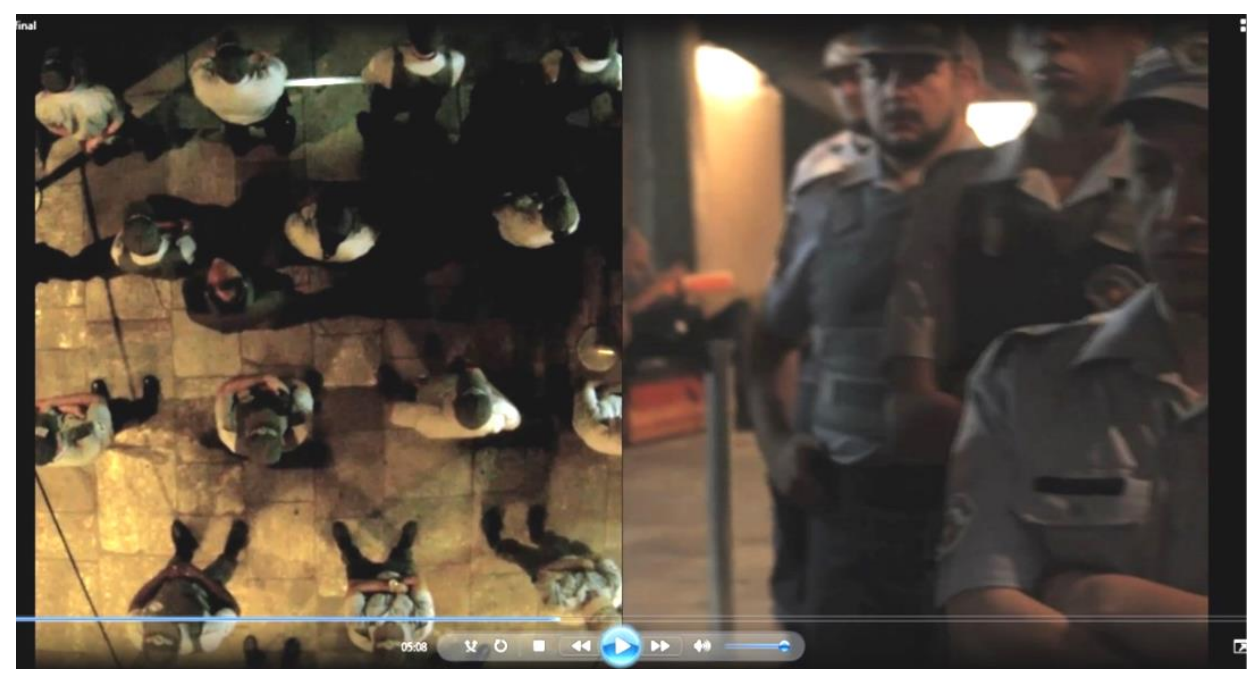

Fonte: Vídeo cedido pelo artista Lorival Cuquinha (2017)

As câmeras captaram o olhar, o movimento e o espaço, mas o produto final após a edição também recebeu o som que dialogava com as imagens contendo manifestações públicas de 2013, além do discurso invertido da ex-presidente do Brasil, Dilma Rousseff, mixado a um som musical alternativo, criação de um amigo do artista. Cuquinha (2017, p.14), no entanto, o considera esse produto um outro trabalho, "mas isso registra o máximo que eu queria conseguir registrar desta performance, mas é outra obra para mim, mas digamos que nesse caso o vídeo consegue", mas em outros trabalhos, nem sempre é possível um registro tão verossímil.

Juliana Moraes (2016) é convicta ao lembrar dos atributos dessa plataforma que, através de sua objetiva, sempre constrói um discurso, do ponto de vista de quem capta com enquadramento, planos, posição da câmera, que diferem do olhar do coreógrafo que 
exige olhares distintos. Segundo ela, alguns trabalhos em vídeo são propostos para a tela e não para o palco, como é o caso de performances.

Moraes considera ainda existir coisas díspares: uma delas seria o registro videográfico, com projeção futura para apreciadores e pesquisadores; a outra, o recurso para recriar ou reperformar uma ação.

Cauê Alves (2016, p. 8), assim como Moraes, reconhece a limitação do vídeo devido às características da linguagem, as opções de captura, ponto de vista e edição, bem como o tratamento do tempo que, mesmo tecendo a mesma trama, não é suficiente para "dar conta de uma experiência mais carnal direta entre o performer e o público". Ele também reconhece que algumas obras são pensadas para essa plataforma, bem como os trabalhos executados em ambiente privado aos quais o público só tem acesso por meio de fotos e vídeos.

\footnotetext{
Amilcar Packer fazia isso no começo dos anos 2002. As performances que ele fazia em casa, depois a discussão mesmo era da imagem, ele fotografava o filme, que ele passava na TV. Então tem artistas que fazem as performances privadas, que o resultado é filme ou vídeo, também é um jeito; outros não, estão nos espaços públicos, obviamente você propõe também uma outra relação com a cidade, com a circulação urbana. Há muitas possibilidades, a verdade é essa, não tem fórmula (2016, p. 8).
}

Até pouco tempo, era difícil e escasso o material estar acessível aos pesquisadores. Naira Ciotti (2017) comentou que durante o desenvolvimento da sua dissertação de mestrado, para se estudar artistas como Joseph Beuys, sua tarefa consistia em recorrer às instituições estrangeiras, como o Goethe, detentoras de filmes dessa natureza. Por se tratarem de obras de caráter patrimonial, estavam disponíveis ao público, mas na língua original alemã. Porém, devido ao desenvolvimento de novas tecnologias, é possível encontrar facilmente esses vídeos nas redes virtuais, ratificando a importância desse registro no âmbito da pesquisa.

Para esta dissertação, os registros de performances foram essenciais, tanto para o entendimento de muitas ações, como para o aprofundamento de questões realtivas à conservação e acervos dessa linguagem. Contudo, diferentemente de Ciotti, vários registros fotográficos e videográficos estavam disponíveis virtualmente à consulta. Apesar da facilidade de acesso a esse material, foram necessárias algumas entrevistas com especialistas para melhor entender certos pontos obscuros não encontrados nas publicações ou nos registros. Essas entrevistas registradas em vídeo, como abordado anteriormente, causaram certo incômodo inicial para o entrevistado pelo contato com uma câmera profissional, tripé, microfone, luz, e pelo cuidado que eles tinham em expor 
suas próprias imagens, porém, aos poucos, eles foram se familiarizando com o contexto e, ao final, demonstraram e ratificaram a importância de tal registro. 


\section{CAPÍTULO III - ACERVOS E COLEÇÕES DE PERFORMANCE NO SÉCULO XX}

Este capítulo aborda as questões referentes aos acervos e coleções de performance em São Paulo/Brasil, procurando entender como elas acontecem e se relacionam principalmente com instituições, museus, notadamente, que trabalham com acervos tradicionais de artes como esculturas, pinturas, gravuras e fotografias. Outro aspecto a ser levantado será como o mercado vem trabalhando com essa expressão artística, no sentido de incluí-la nas coleções.

\subsection{AS INSTITUIÇÕES: GALERIAS E MUSEUS}

Tradicionalmente, museus e galerias foram espaços de conservação e contemplação de objetos de arte, porém, tudo indica que esse paradigma vem sofrendo modificações, quanto a seus acervos sobretudo devido ao aparecimento das chamadas artes conceituais e/ou media $a r t^{29}$, com uso de novas tecnologias. Questões quanto à objetificação da obra, que parecia ser o cerne dos acervos artísticos no final do século $\mathrm{XX}$, se depararam com linguagens, como a performance, que traz em sua bagagem características como a efemeridade da ação, impregnada de simbologias e significados, como suporte de expressão, o que facilita a integração com o público, bem como um diálogo direto.

Esse cenário, apesar de sua relevância, não tem sido fácil para as instituições, pois a inclusão de performances em suas coleções envolve tanto questões conceituais, quanto os espaços físicos que, muitas vezes, necessitam de adequação. Expor instalações que, por vezes, são de grande porte não é o mesmo que armazenar um quadro ou uma escultura. Além da dimensão e área ocupada, há necessidade de se pensar em uma iluminação conveniente, na adequação das paredes, ou seja, é uma colmeia de combinações, que precisam ser reestruturadas para incorporar essas estruturas. $\mathrm{O}$ mesmo acontece com vídeos, que dependem da estrutura de novas mídias, ou até mesmo àquelas

\footnotetext{
${ }^{29}$ Media art refere-se a obras de arte que dependem de um componente tecnológico para funcionar. O termo "mídia" aplica-se a qualquer dispositivo de comunicação usado para transmitir e armazenar informações. Ao incorporar tecnologias emergentes em suas obras de arte, os artistas que usam novas mídias estão constantemente redefinindo as categorias tradicionais de arte. Ao longo dos anos, numerosas disciplinas artísticas caíram sob o guarda-chuva da "arte da mídia", incluindo: Arte Biotecnologia; Arte do computador; Arte digital; Arte eletrônica; Arte interativa; Arte cinética; Arte multimídia; Arte da rede; Arte robótica; Arte de som; Arte espacial; Arte tecnológica; Arte de vídeo; Arte da web (GAGNIER, s.d.).
} 
que utilizam plataformas que estão em desuso, criando desafios para as instituições, que procuram caminhos para atender às novas tendências.

Quando à linguagem, a performance absorve várias expressões e conhecimentos, e as instituições enfrentam um debate ainda maior: como tratar essa linguagem em locais tradicionais de conservação e exposição?

O universo da performance é um campo em aberto, sem sistematização rígida. Liliane Coutinho (2015, p. 49), integrante da direção da Associação Internação de Críticos de Arte de Portugal enfatiza que: "cada obra de arte é o início de um diálogo e um diálogo tem sempre vários intervenientes". Coutinho exemplifica isso com um trabalho de Tino Sehgal - "Situações Construídas" -, no qual os vendedores das exposições são transformados em performers, nos museus.

\begin{abstract}
Instaurou-se um novo paradigma de mercado na relação museu-perfomer. As suas situações não se guardam a não ser na memória. O que o museu compra e proporciona é uma experiência. Aqui não falamos de uma economia de mercadorias, coisas, mas, de experiências, que se ancora em espaços, objetos e instituições, transformando-os em material de trabalho (COUTINHO, 2015, p. 49).
\end{abstract}

As instituições de arte estão buscando meios de expor ou reencenar performances, pensando na programação, construindo acervos e garantindo debates sobre o universo plural acerca dessa produção artística. Urge considerar fatores culturais, sociais, políticos, mercadológicos, que acabam tendo que assumir uma posição, quanto aos valores que seu acervo e suas exposições vão apresentar.

Figura 40 - Performance “Zona morta”, Mauríco Ianês, Galeria Vermelho, São Paulo, 2007

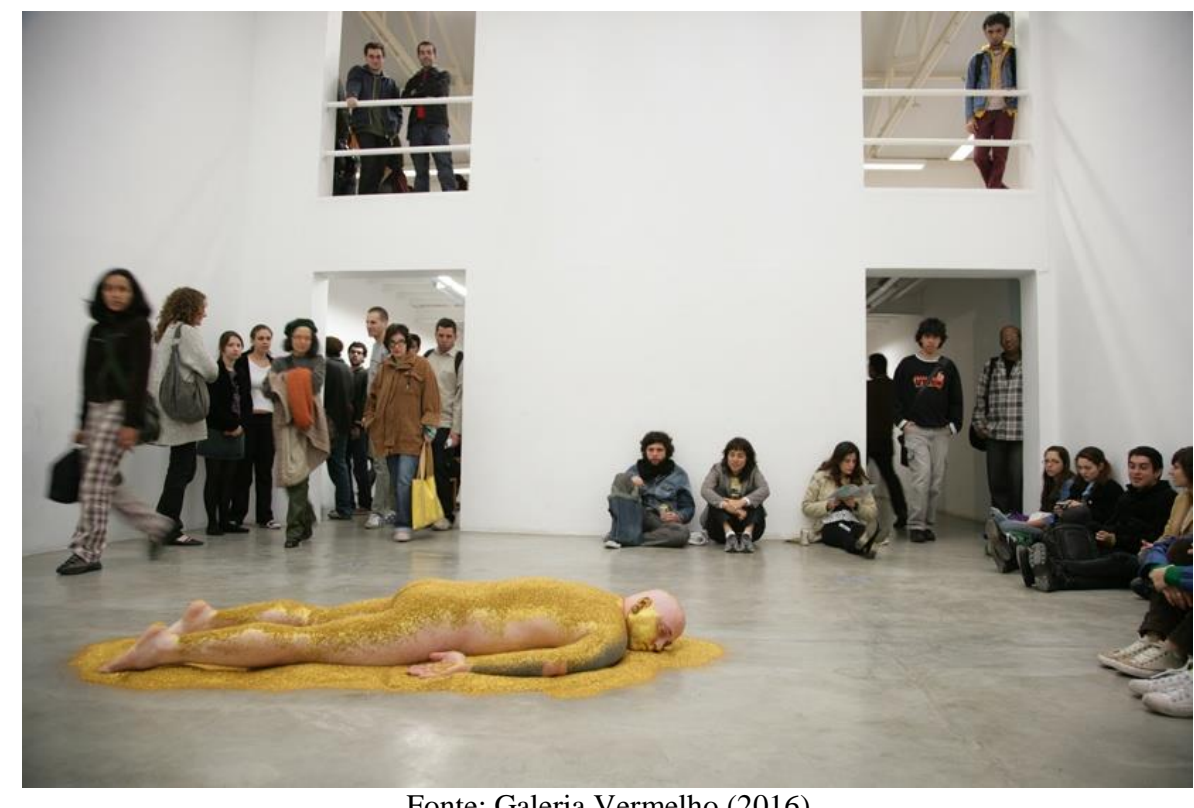

Fonte: Galeria Vermelho (2016)

As pesquisas sobre essa linguagem performática nascem contestando a oficialização da arte, que hoje a integram, refletindo a respeito dessa dicotomia. As 
instituições artísticas, de modo geral, quando se apropriam de uma obra de arte dão um novo significado a ela, mediante regras e propostas artísticas. "Institucionalizar é 'dar direito de cidade'. Quer dizer, oficializando, cria condições para que algo exista e se possa desenvolver no seio de uma comunidade social" (COUTINHO, 2015, p. 47). Essa colocação aprofunda e faz emergir o discurso que a performance pode estabelecer, quando pertencente oficialmente a acervos.

Esse panorama foi a grande motivação da Mostra Verbo, segundo seu diretor Gallon (2016), que acredita que a performance e os artistas em um passado próximo foram tratados como meras animações de eventos e os próprios artistas tiveram que descobrir formas para garantir o status dessa linguagem.

A performance não pode ser tratada como animador de festas, ou seja, fazer uma performance em um dia de uma abertura [de exposição], onde as pessoas estão querendo se encontrar, conversar, e o artista pobre coitado está lá jogado no chão, enquanto as pessoas bebem vinho. A gente sempre quis sair desse formato (GALLON, 2016, p. 2).

A Mostra Verbo percebeu a necessidade de debates conceituais, sobretudo quanto à guarda e à administração dos materiais, mesmo por que havia uma postura defensiva por parte das instituições, pela dificuldade de se manter um acervo imaterial.

\footnotetext{
Há uma série de questões que deve ser repensada e isso faz parte do discurso atual da performance. Ou seja, como é que você guarda a performance, como você a documenta, como que você a reencena, são estes três eixos. Primeiro como se reencena uma performance, são coisas que estão ligadas entre si, e que são essenciais para criação de um acervo (GALLON, 2016, p. 4).
}

Para as instituições ligadas ao mercado de arte, resolver a questão da reencenação da reperformance pode alavancar os caminhos que levam essas manifestações a ingressarem nas coleções e acervos, além, é claro, de se levar em conta a individualidade de cada artista e de cada obra e os desdobramentos que cada trabalho propõe.

O museu, com a função de expor e transmitir seu patrimônio, ideologicamente é uma organização sem fins lucrativos que, no século XIX, acolhia as obras de artistas, com acesso restrito do público. Contudo, sua natureza se transformou em local de conservação e exposição, além do caráter pedagógico e educativo. O público vem sendo visto como partícipe do processo, interagindo e participando como parte da totalidade das ações da instituição, não como mero contemplador. Entretanto, a missão do museu com o tempo vem se metaforizando, devido a muitas variantes, como as dualidades em conciliar trabalho especializado com o não qualificado; e/ou obras únicas e extremamente valiosas. Outro aspecto é o baixo orçamento para administração, e a crescente inversão: aumento de custos e diminuição de público. Contudo, o mote desse tipo de instituição em ser 
gratuito parece se manter, mesmo com as doações do Estado diminuindo, associada à baixa frequência do público, com rendas diminutas dos ingressos, em oposição ao aumento de doações particulares.

“O museu tem por função a transmissão de um legado, de geração em geração, por meio da conservação das próprias obras e (...) “o museu é um serviço coletivo financiado pelo Estado" (BENHAMOU, 2007, p. 87). Entretanto, a ideia de perpetuar alguns objetos, obras e ideias, se conserva nessas instituições.

A importância da memória para a humanidade e seus devidos registros são elementos que podem tornar "eternos" ações e objetos. A performance não é um objeto, um bem material; não obstante, possui memória pertencente ao universo imaterial, conferindo-lhe o direito de pertencer a coleções e acervos. Edson Leite (2011, p. 120) fornece argumentos plausíveis referentes ao campo da imaterialidade:

\begin{abstract}
Os bens culturais estão impregnados de sentido que vão além de sua materialidade. A razão de um monumento ser considerado um patrimônio cultural está não apenas em sua materialidade, mas na demonstração da engenhosidade humana que contém sua construção e, geralmente, no simbolismo que lhe é atribuído.
\end{abstract}

As instituições brasileiras parecem ratificar essas práticas. Em uma ação pioneira, o Museu de Arte Moderna de São Paulo [MAM-SP], em 2000, adquiriu a obra "Bala de Homem $=$ Carne/Mulher=Carne" (figura 20), da artista Laura Lima, executada por duas pessoas. Há um detalhe interessante sobre essa performance: a autora não participa da sua realização, ficando a execução para outros artistas que são contratados. Essa proposta de atuação abre um debate: artista é quem cria, executa ou ambos? Essas reflexões são elementos que ajudam a dar sentido para acervos dessa natureza e justificam a proposição deste estudo. Em 2015, a Pinacoteca de São Paulo adquiriu outra obra dessa natureza, do performer Maurício Ianês, “O Nome” (figura 16), para ser executada por funcionários; e, em 2016, uma colecionadora adquiriu a obra "Parangolé" (figura 28), de Lorival Cuquinha, na SP-Arte 2016 e a doou ao Museu de Arte Moderna de São Paulo [MAM$\mathrm{SP}$, que também para ser reperformada contará com um artista contratado, como nas obras de Lima e Ianês. Essas aquisições marcam uma nova tendência nas coleções dos museus brasileiros, destacando os de São Paulo, foco deste estudo.

Além das fronteiras brasileiras, algumas instituições têm aberto espaço para a arte do desempenho, para ações com a presença do corpo.

Exposição ao vivo e interativa é cada vez mais um elemento básico da programação do museu. "A arte do desempenho está sendo abraçada de uma maneira totalmente nova", disse Philip Bither, curador sênior de artes cênicas no Walker Art Center em Minneapolis. "Estamos vendo muito mais um compromisso institucional com artistas que estão fazendo um trabalho efêmero". 
Ver o desempenho da arte nos museus não é novo. Em 1969, Meredith Monk apresentou a primeira parte do "Suco: uma cantata de teatro em 3 parcelas" no Museu Guggenheim, transformando todo o museu em palco. O trabalho de coreógrafos como Merce Cunningham e Trisha Brown tem sido realizado nos museus há muito tempo. E instituições como o centro de artes contemporâneas Walker, Roy e Edna Disney/CalArts Theatre em Los Angeles (conhecido por suas siglas, Redcat) e o Wexner Center for the Arts da Ohio State University, em Columbus, fizeram sua reputação sobre performance visual e artes da mídia. (POGRENI, 2012).

O Museu de Arte de São Paulo [MASP] não possui em suas coleções obras nessas condições, apesar de muitas ações performáticas acontecerem no espaço vazado do prédio, devido a sua visibilidade e por ser espaço público. Já o Museu de Arte Contemporânea da Universidade de São Paulo [MAC-USP] só possui obras catalogadas como registro de ação, registro de performance e registro de instalação, que aconteceram no museu ou foram doadas, mas não podem ser reexecutadas a critério do museu, pois não são obras tombadas, são registros (CABRAL, 2017).

A artista Laura Lima (2017, p. 4), segundo suas palavras, achou: "absolutamente fantástico" sua obra ser a pioneira nos museus do Brasil, porque quando ela constrói uma obra está operando no campo da História da Arte, com comportamentos, e quando se torna colecionável carrega a vocação de ser transformadora.

Para Maurício Ianês $(2017$, p. 2), o museu agregar performances nos acervos tem a mesma relevância do ato de se colecionar uma pintura, por "fazer parte da produção do conhecimento através de ações artísticas da humanidade". Ianês lembra que na Europa tem instituições como o Centre National des Arts Plastiques, detentor da sua obra "Recusa", que também tem em suas coleções coreografias e textos de dramaturgia, enquanto o Centro Georges Pompidou, localizado em Paris; e o MoMa, sediado em Nova Iorque possuem obras de Martha Graham e Samuel Beckett, ratificando a importância da performance estar presente nas coleções das instituições de arte.

A curadora Fernanda Pitta (2016) mencionou que no período da aquisição da obra de Ianês, para melhor afinar a inclusão no acervo foi feita uma reunião junto com Ianês referente ao recebimento da obra e questões relativas ao acervo foram tratadas, bem como a responsabilidade junto à Secretaria de Estado da Cultura, por se tratar de um patrimônio do Estado.

Pitta (2016) ressalta que para agregar essa obra ao acervo, após a sua seleção começaram as tratativas com o artista, para recebê-las por meio de um patronato.

Um grupo de patronos da arte contemporânea. Eles adquiriram essa obra em uma edição do programa de 2014 e ela entrou para o acervo em 2015. Depois de já ter sido apresentada, ela foi apresentada aqui no museu [a Pinacoteca] em 2013, ela foi apresentada ao grupo de patronos em 2014 para aquisição. Adquirida. E foi, finalmente, incorporada em 2015. Para receber essa obra, nós tivemos três momentos com o artista. Um primeiro momento foi antes de a 
receber, de fato, quando já era certo que ela seria adquirida, nós tivemos uma reunião com ele aqui (PITTA, 2016, p. 2).

Segundo Pitta (2016), outras ações performáticas fizeram parte da programação, dentro da Pinacoteca do Estado de São Paulo, como a de Tino Sehgal, que aconteceu no octógono, mas não foi agregada ao acervo, contudo a instituição sempre que possível acolhe essas expressões.

Por outro lado, essa linguagem oportuniza questões relativas à áureado artista, já que algumas obras podem ser executadas por terceiros e a relação com o público "apresentar trabalhos em que não há essa presença ou essa presença ser subvertida, digamos assim, por uma outra situação, é um jeito de se questionar e discutir essa construção aurática em torno do artista”, conforme explica Pitta (2016, p. 7). Pitta questiona a própria instituição, devido à experiência direta com o público e funcionários, principalmente quanto à orientação dos visitantes para as vivências que a performance propõe.

Segundo Cauê Alves (2016), algumas performances propiciam institucionalização, tombamento e inclusão na reserva técnica, mesmo que essa linguagem tenha se iniciado com caráter anti-institucional, o sistema a engoliu, devido aos artistas e por suas necessidades de serem representados e por "quererem estar nesses lugares, quererem estar nestas instituições, no circuito comercial, no circuito contemporâneo como um campo" (ALVES, 2016, p. 3).

Alves (2016) relembra da atuação de Marina Abramović no MoMa, na qual paralelamente aconteciam remontagens de outras performances, inclusive uma que a própria Marina e Ulay, seu parceiro, haviam feito no passado. Ambos nus em uma porta, em que o público tinha que passar por eles, interferindo na intimidade de ambos, porém nessa reperformance os atores contratados para a ação foram constrangidos pelo público. Segundo Alves (2016), foi por ser outro momento e a reexecução ser sempre outra coisa, porque em qualquer expressão de arte, cada momento terá uma leitura, uma obra, uma mesma pintura; curadorias diferentes proporão outros olhares, e cada reencenação da performance trará algo do passado, provavelmente esta é a grandeza da arte.

Para instituições como o SESC (FRAZÃO, 2016), o importante em lidar com arte é promover o debate aberto com o público referente à produção artística, na qual a performance está inserida, como o fenômeno das artes visuais nos dias atuais que difere das do passado, quanto à concepção do termo "arte", devido à velocidade que o mundo se transforma. Em performance é similar, se faz necessário compreender a capacidade simbólica nesse nicho. Neste contexto, para o SESC, é fundamental polemizar a 
performance historicamente e seus procedimentos, sua sedimentação em diálogo com o público, oferecendo informações e condições, bem como ocorre com outras linguagens artísticas, no universo da história da arte.

Quando a exposição “Terra Comunal”, de Marina Abramović aconteceu no SESC Pompeia, esta foi tratada como um fenômeno, a trajetória da artista deveria ser tratada historicamente, mesmo porque a exposição trouxe o "Método", vídeo que orientava o público a se tornar performer também. Uma estratégia peculiar da performer foi a de construir possibilidades de guardar e conservar suas ações.

Para o SESC era relevante integrar artistas brasileiros, oito ao todo, que durante o período de exposição estiveram presentes com suas obras e ações, interagindo com o trabalho de Abramović e com o público. Um dos artistas, Maikon K se apresentou nu em

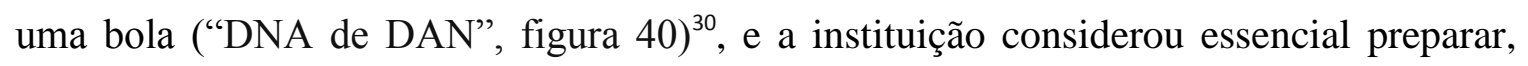
informar e contextualizar o público, já que a instituição fomenta o diálogo aberto com seu visitante (FRAZÃO, 2016), e recebe público heterogêneo. É eficaz salientar que o SESC não é um museu, não possui acervo de performance, mas é um espaço relevante na cidade de São Paulo, que oferece uma ampla diversidade de exposições e atividades culturais e artísticas, consolidando e sendo fonte de informação das interfaces da arte.

\footnotetext{
${ }^{30}$ Em "DNA de DAN", o performer mantém-se imóvel, enquanto uma substância é passada e seca em seu corpo. Após essa etapa, a imobilidade se dissolve. A ação do tempo sobre o corpo, o ambiente artificial, a construção de outra pele e a relação com as pessoas são dispositivos para esta experiência. Maikon K trabalha nas fronteiras entre performance e dança; teatro e ritual. $\mathrm{O}$ foco de sua pesquisa é o corpo como instaurador de realidades e matriz simbólica. Há treze anos estuda a alteração da consciência através de práticas corporais e ritos em ligação com os elementos da natureza (YOUTUBE, 2015).
} 
Figura 41 - Performance "DNA de DAN", Maikon K, na exposição "Terra Comunal", 2015

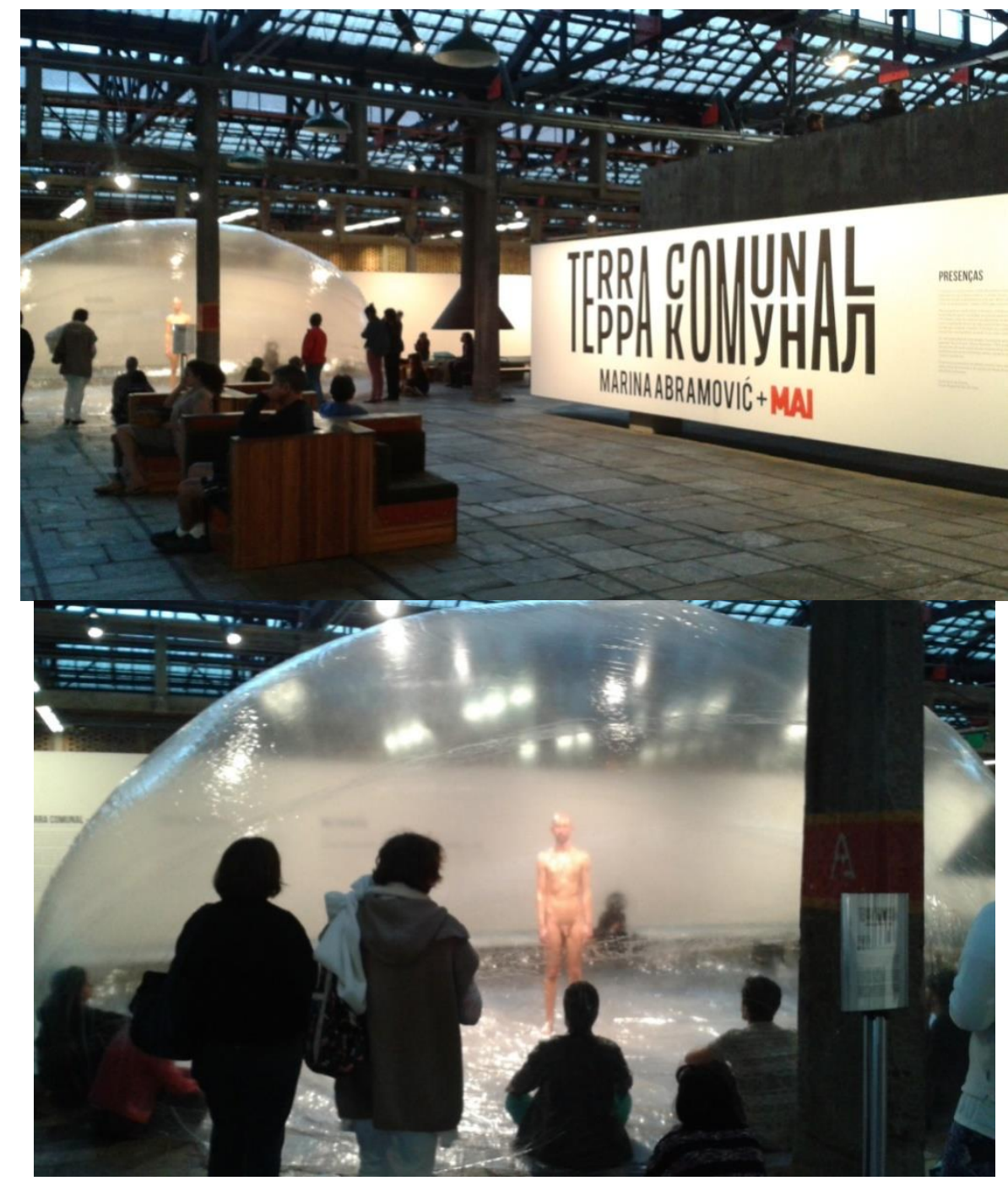

Fotos: Joseane Alves Ferreira, 2015.

Já Cuquinha (2016) quando produz uma obra procura colocar valores, fomentar costumes, e até questionar seu poder de aceitação. Desta forma, os espaços expositivos interessam a ele, por serem espaços de expressão e serem parte integrante do trabalho. Em o policial "Parangolé" (figura 28), quando exposto na SP-Arte 2016, segundo Cuquinha (2016), o local que normalmente recebe uma determinada classe social um pouco mais privilegiada, que costuma se locomover via carro e não tem relação direta com a rua, com a cidade, quando se deparou com o policial, questionou aquela presença, já que o ator dessa ação ficava interagindo com o público com olhar intimidador.

Esse olhar nas ruas com negros ou pessoas com aparência mais simples é comum, mas para o público da feira foi inusitado, provocando indagações, tais como, isso é obra? $\mathrm{Ou}$, tem algo de valor aqui? Essas abordagens interessam ao artista e esses ambientes são primordiais, por serem "partes conceituais da obra e me interessa eu criar dentro desses 
ambientes como friç̧ão mesmo. Aí vem esse signo do contestador. Acho que na verdade não é uma contestação, é uma resignificação de valores" (CUQUINHA, 2016, p. 5).

Outra ação com policiais aconteceu na Galeria Baró, em São Paulo, na qual um conjunto de policiais se colocava no local e o público deveria passar por eles, e serem observados como um baculejo ${ }^{31}$. Duas pessoas ao vivenciarem o momento demonstraram certo medo, mas em seguida o ressignificaram comentando que o local tinha segurança da Polícia Militar, o que denota uma dicotomia, segundo Cuquinha (2016). Para duas pessoas, o "chique" era o público, no local privado, contudo o mais interessante para o artista é esse "inconsciente coletivo", de se apoderar do público e privatizar o que é público, os policiais são personagens públicos, mas quando obra em instituição de arte se privatiza. Trabalhos com o corpo, como os deles, criam essas proposições, daí ter obras como o "Parangolé" no museu é fundamental para garantir interlocução com seu público, mesmo porque o performer acredita que trabalhos com o corpo vivo, consciente, "que cada obra vai ter uma idiossincrasia, vai ter uma especificidade de como vai estar nesse acervo" (CUQUINHA, 2016, p. 7), indicam diversidade e riqueza de propostas artísticas.

Concluindo, para Cuquinha (2016), um museu coerente com a cultura presente em sua sociedade não tem saída, deve adquirir performances para ser contemporâneo.

Ciotti (2016), quando intui os métodos de estruturação de acervos de performances em museus, questiona como colocar corpo dentro do museu, pergunta que se fez desde seu doutorado, quando fez residência artística como performer na casa das Rosas em São Paulo, que na época era denominada por Galeria Municipal de Arte Digital. A experiência consistia em ter seguro de vida, alimentação e dinâmicas de convivência no espaço, no período de meio-dia às cinco da tarde, em um sistema de exposição, mas sem comunicação com o público e a família. No entanto, com internet, e câmeras nas salas gerando imagem. “(...) ao mesmo tempo, que nós estávamos confinados de um lado, como um quadro, como uma escultura, como um objeto, em uma outra dimensão, a gente estava no universo, solto" (CIOTTI, 2016, p. 3).

Para a performer e professora de performance, Naira Ciotti, essa abordagem na época e até o presente momento provoca impacto junto à curadoria, porque performance em museu solicita reexaminar abordagens tradicionais, aliadas a contextos contemporâneos. Ela também se considera otimista quanto ao aperfeiçoamento da tecnologia da performance, similar a outras linguagens, com inclinação para regulamentação, como o grupo "ligado ao Guggenheim que é o John Hipólito (...) que só

\footnotetext{
31 “Baculejo é como você levar uma dura aqui, lá em Pernambuco é baculejo" (CUQUINHA, 2016, p. 5).
} 
pesquisa como guardar coisas que não são normais, assim, que não dá para arquivar tranquilamente, obras que problematizam os museus e os acervos" (CIOTTI, 2017, p. 9).

Não se pode negar que esta linguagem não é fácil de digerir, até mesmo compreender suas metáforas e as instituições no Brasil precisam lidar com isto, em exposições e eventos. Felipe Chaimovich (2016), do MAM-SP, afirma que em um museu: “O público pode se perguntar sobre a natureza da ação performática em exibição, e as dúvidas da própria instituição sobre as condições eventualmente não definidas pelo artista devem ser explicitadas ao público".

As instituições estão em um contínuo caminhar para garantir ao público o acesso das mais diversas obras e linguagens artísticas. A performance corrobora no sentido de encontrar meandros da história do homem, da civilização na qual está inserida, afinal a arte pode ser considerada como um filtro da realidade, projetando não só o impacto visual, como a emoção causada pelas obras.

São muitos os indícios que apontam para construção de acervos de performance nas instituições, galerias, mas as dificuldades de sistematização ainda carecem de muita reflexão, inclusive dos próprios artistas. Questões ligadas à própria história da linguagem e de seus artistas estão nas mesas de debates, conforme será abordado a seguir.

\subsection{O MERCADO DAS ARTES E A PERFORMANCE}

A performance passou a ser aceita como meio de expressão artística independente na década de 1970. Naquela época, a arte conceitual - que insistia numa arte em que as ideias fossem mais importantes que o produto e numa arte que não pudesse ser comprada ou vendida - estava em seu apogeu, e a performance era frequentemente uma demonstração ou uma execução dessas ideias (GOLDBERG, 2001, p. VII).

$\mathrm{O}$ ato de criar, em geral, é associado à livre expressão, porém na prática a liberdade nem sempre é plena. Historicamente, o artista criava conforme seu patrocínio ou certas regras sociais ou de mercado, mas esses aspectos não comprometeram a qualidade da obra, os artistas sempre deixaram suas marcas e valores em seus trabalhos. Pode-se afirmar, assim, que a obra de arte sempre foi um espelho de seu momento, de seu criador e de sua época.

No modernismo, o movimento de aproximação entre artista e sociedade se inseria num projeto de transformação social. Hoje prevalece o imperativo capitalista de ampliar o público consumidor e reforçar gostos e valores (...) a obra de arte, como dinheiro, se torna puro valor de troca (TRIGO, 2009, p. 80).

A arte tradicionalmente para sobreviver, ter o direito de exercer o ato de criação e execução de suas atividades esteve atrelada a esquemas e estruturas financeiras, afinal a 
produção artística tem custos e depende de recursos de diversas fontes, normalmente esteve dependente de patronos. Os mecenas foram primordiais para o desenvolvimento das práticas artísticas desde a Antiguidade, garantindo que muitos artistas trabalhassem e sobrevivessem de seus ofícios.

O termo "mecenato" parece ter sido forjado como referência às atividades desenvolvidas por Gaius Maecenas, amigo pessoal do Imperador Caio Augusto, que na época exerceu funções administrativas no império romano, entre 30 a.C. e 10 d.C. Embora sem ter título oficial, ele substituía o Imperador quando este se ausentava, o que lhe conferiu plena autonomia na alocação de recursos. Maecenas foi grande articulador das ligações entre o Estado romano e o mundo das artes. Além de admirar a produção artística e de ser escritor, Maecenas parece ter percebido que ao aproximar artistas, filósofos e pensadores do governo que representava, carregava para o Estado a aceitação e o prestígio de que os artistas gozavam junto à população. Dois dos grandes escritores da época, Horácio e Virgílio, receberam atenção especial de Maecenas e sob seus auspícios desenvolveram parte de suas obras (REIS, 2003, p. 6).

São muitas as prerrogativas do mercado de arte, algumas mais fáceis de identificar: obras tombadas, outorgadas pela história; profissionais da trama artística (críticos, conservadores de museus, marchands, colecionadores e outros), com o chamado "gosto" atuam, articulam, classificam e alimentam tendências e, por fim, interferem no mercado; do mesmo modo que as demais obras adquiridas pelos museus, influenciando na valoração das mesmas.

Outras ações comerciais, como expor o artista em feiras e salões, também dão visibilidade e credibilidade a ele, às suas produções e aos marchands. Contudo, o preço de uma obra é o reconhecimento da sua qualidade, de seu autor, que passa por peritos que avaliam questões estéticas, a história da arte e os movimentos artísticos. A autenticidade também é avaliada no sentido de eliminar incertezas, o que não é sempre possível, nem mesmo obras únicas têm essa garantia, pois o preço pode sofrer muita variação. Outro elemento que interfere na valoração é a fama do artista, o conjunto de suas obras, suas exposições, prêmios, preços de obras vendidas, presenças em revistas especializadas, renda dos compradores, enfim são muitas as tensões. "Ao contrário das ações de uma empresa, as obras de arte não são substituíveis nem semelhantes; é por isso que o vendedor assume uma posição monopolista das obras que possui” (BENHAMOU, 2007, p. 84).

O mercado apesar de sua estrutura sofre alterações por vezes devido a questões culturais, que orientam o valor e o status dos artistas. Desde os gregos que exaltavam a 
beleza física e a eloquência, a arte possuía status por ser considerada do universo das ideias, junto à filosofia e a poesia, além da música, devido sua métrica matemática. Segundo Platão, as crianças até a adolescência deveriam fazer estudos literários, seguidos de música, incluindo também dança. Não obstante, a escultura, que representava o corpo e as divindades, bem como a pintura, eram consideradas trabalhos físicos, funções dos escravos, muito distantes das ações dos homens livres, que procuravam refinamento do pensamento, do espírito, um bem maior (REIS, 2003).

Notadamente, os artistas estão subordinados a outras questões, que não as estéticas e habilidades técnicas. Nessa lógica está inserida a performance que, como escultores e pintores na Antiguidade, conquistaram lugar no pódio das artes, porque, devido a valorização que os gregos impregnavam no corpo, sua devida representação era considerada aplicação das ciências nobres e da complexidade do corpo, além de homenagear as divindades. Assim, desde a Antiguidade, ações cênicas ocuparam lugar de destaque na sociedade, ao lado da eloquência, que fez com que a arte reconhecesse o mundo das ideias, como a filosofia e a poesia (REIS, 2003). Assim, a performance que pode ser considerada desdobramento dessas ações que fazem uso do corpo como ferramenta de expressão vem encontrando espaço no mercado de arte.

Algumas performances são criações individuais, mas de execução de coletivos, de terceiros, como se pode constatar nas obras de Laura Lima, que não executa suas concepções, quem o faz são terceiros contratados para desempenhar as ações ("Quadris de homem = carne / mulher = carne" 1995; "Bala de homem = carne / mulher = carne", 1997 e "Palhaço com buzina reta - monte de irônicos", 2007). Essa lógica parece ter origem distante, no Renascimento artistas renomados agregavam ao seu redor vários artesãos para executar seus trabalhos, facilitando-lhes coordenar muitos projetos. Somente no século XVI, casamentos entre artistas e famílias com certo status, foram legitimados (REIS, 2003); e essa constatação atribui ao fazer artístico certa aura, que esbarra na celebridade e até mesmo no divino.

É imperativo ressaltar a ótica do sistema capitalista, as famosas casas de leilões como Sotheby's e Christie's, que apresentam arrecadações de grande volume. Segundo Pinho (2008, p. 9), durante uma grave crise no setor econômico nos Estados Unidos, devido ao estouro da bolha imobiliária, percebeu-se que "a mão invisível do mercado, a eficiência alocativa e a liberdade individual não são tão confiáveis como supunham alguns reputados mestres de Economia”. Essa autora comenta, ainda, que dias depois, um leilão da Sotheby's arrecadou em poucas horas cerca de US\$ 200 milhões com obras contemporâneas. 
De acordo com Cauê Alves (2016), um dos curadores de performance da SP-Arte 2016, é consenso que feiras de arte sejam espaço para comercialização e circulação de arte, além da visibilidade que proporciona aos artistas e às instituições. Uma inquietação de Alves, junto aos alunos de performance do Centro Universitário Belas Artes de São Paulo foi introduzi-los nos âmbitos das feiras de arte, como complemento à formação de futuros artistas, operando certa fricção. Todavia, ele tem consciência, que os colecionadores ao saírem de feiras de artes, desejam levar objetos de arte para suas coleções e acervos:

\footnotetext{
Como comercializar performance? Como se pode comprá-la? Levar essa discussão da performance para uma feira de arte, e sendo uma universidade, que está formando um público, uma nova geração que está produzindo (...) e fazer com que as pessoas reflitam sobre isso, a pensar modelos, a pensar possibilidades (ALVES, 2016, p. 2).
}

Moraes (2016) aponta, por outro lado, que no universo da dança, que também utiliza o corpo como ferramenta e objeto de arte, isso também acontece. Quando peças de dança são compradas por companhias é via contrato, normalmente acompanhadas de orientações e, por vezes, um especialista acompanha a montagem, chancelando com selo de qualidade a produção. Nesse caso, pode-se fazer uma conexão com a performance, na qual a comercialização também é via contrato e a reperformance carece de orientação do criador, mas salienta que o comércio de performance em vídeo, devido ao mundo virtual encontra dificuldades no mercado.

Já Ciotti (2017) considera a comercialização de performance consagrada via fotos e vídeos, tal como a arte conceitual, por ser fonte de informação. Contudo, difere do que chama "fúria de documentação dos celulares", pois são obras produzidas "sob a direção do performer" (CIOTTI, 2017, p. 8), que diferem sobremaneira do produto final.

Ciotti (2017) acredita no fortalecimento do mercado de performances e particularmente não percebe dificuldades. Ela observa o crescimento da performance e sua reverberação no mercado. Outra perspectiva são os editais, que segundo ela, em outras linguagens como teatro, dança, artes visuais etc. abrirão espaços para performance, de forma híbrida, segundo o pressuposto de "Marvin Carlson (1935 - ...), que afirma, que nossa sociedade é da performance, é uma virada performativa que a gente está vivendo" (2017, p. 10). Por fim, Ciotti (2017) menciona que acredita na normatização dos processos da performance.

$\mathrm{O}$ mercado brasileiro de arte indica crescimentos no que se refere à performance. Na SP-Arte [2016], a obra Parangolé, de Lourival Cuquinha, foi vendida pela Baró Galeria por $\mathrm{R} \$ 25.000,00$. A colecionadora Cleusa Garfinkel, que adquiriu a obra a doou para o MAM-SP, instituição que também tem aumentado seu acervo de performance 
(FOLHA DE S.PAULO, 2016, p. C1). Interessante observar a estratégia de comercialização da obra de Cuquinha pela triangulação entre a galeria, que representa o artista; a instituição que recebeu a obra, o MAM-SP, e o curador Felipe Chaimovich, que esteve presente na negociação; e a feira SP-Arte, que efetivamente comercializa arte. Essa transação garantiu que essa linguagem passasse a estar presente em um museu na cidade de São Paulo, a maior cidade de negócios brasileira, além da presença da colecionadora e incentivadora, que poderia ser tratada de "mecenas Garfinkel", que fez a doação.

Certamente, tanto a colecionadora quanto o museu não levaram para o acervo ou reserva técnica um objeto físico, mas um documento que garante a propriedade da obra e a sua reapresentação, segundo a curadoria do museu. Isso indica que instituições tradicionais como museus passaram a trabalhar com a imaterialidade.

Esse advento não é necessariamente novidade, pois o cinema, desde sua aparição, tem a mesma lógica. Quando usava a plataforma película, apesar dessa materialidade, o objeto de apreciação só acontecia na tela, onde o filme existe e dialoga com o público (SANTOS, 2016). Afinal, filme são rolos de película, objetos sem magia, que só conseguem expor ao mundo suas metáforas, conceitos e ideias quando projetados. Atualmente com a mídia digital se tornou efetivamente imaterial. Outro importante aspecto consiste na comercialização dessa linguagem: o criador e/ou produtor/ diretor precisa das distribuidoras para intermediar a exibição, que fica com os direitos comerciais do filme, mas a autoria, assim como ocorre na performance, sempre será do criador.

Comercializar performance sempre foi o mote da Galeria Verbo, por acreditar que os artistas necessitam sobreviver, ter condições de subsidiar e desenvolver suas pesquisas. Entretanto, é indispensável que os artistas se conscientizem quanto à reperformance, como ela irá acontecer, já que o colecionador ao comprar uma obra dessa magnitude irá levar apenas documentos, que lhe darão o direito de reexecutar a obra, mas a singularidade de cada artista deve revelar o conceito e estética do artista.

De acordo com Gallon (2016), a Galeria Vermelho até 2016 só havia comercializado duas performances, a de Ianês à Pinacoteca, e outra para fora das fronteiras brasileiras, a França, mas ele questiona: "será que essa institucionalização da performance, (...) a entrada dela nos museus e na coleção particular, vai tirar a contundência da performance?” (GALLON, 2016, p. 8). Ele considera que essa linguagem carrega caráter contestador, principalmente quanto ao mercado consumidor e à instituição adquirente. Ele teme que se assemelhe ao mercado do vídeo, que quase extinguiu, mesmo que "o fetichismo do mercado atinge todos os níveis do mercado, a 
performance não está alheia a isto" (GALLON, 2016, p. 8), mas reconhece que a performance está presente em todos os campos da arte atual.

A relação do mercado com o museu, como local de circulação e produção de arte na qual o mercado, vem consolidar esse sistema e as obras de arte são produtos inseridos no mercado faz com que a curadora da Pinacoteca de São Paulo acredite ser imprescindível ratificar o valor simbólico e estético da obra. O museu é incontestavelmente território dessas relações, do sistema de arte. As obras e artistas ao adentrar nessas instituições, garante visibilidade à obra e ao artista, agregando valor.

\footnotetext{
A gente sabe que o museu também está escrevendo essa história (...). Então, esse caráter de permanência (...) é uma preocupação que a gente tem. A gente tem critérios para isso, a gente tem uma política institucional, com relação ao que pode ser adquirido, seja por meio de doação, por compra, legado (...) transferência, comodato (PITTA, 2017, p. 11).
}

Cuquinha (2017) considera que o mercado deve ser estimulado, mas questiona a liberdade de criação do artista, afinal é difícil estar totalmente divorciado do mercado. Mas, segundo ele, dialogar com o mercado pode ser uma oportunidade de se imbricar com o contexto em que está inserido e seu " meu modus operandi permite eu ser permeado até por instâncias como mercado, uma rua, uma ocupação da Funart, uma passeata, uma galeria, ou uma proposição de residência" (CUQUINHA, 2017, p. 13). Dialogar com o mercado pode ser uma oportunidade de se imbricar com o contexto em que está inserido, tencionando-o. Outra questão que Cuquinha (2017) aborda são peculiaridades de artistas que atuam com corpo vivo e a inserção dos "resíduos" em acervos.

Já Laura Lima (ano) tem uma visão peculiar de acervos de performance, pois não os percebe como imaterial porque as ações abarcam documentos, instruções, porém não é simples sua apropriação por causar desconforto: “(...) compre essa obra, mas lembre-se que você vai ter que a refazer toda vez que você tiver que deixá-la presente". Também sua catalogação não é simples, como os objetos tradicionais de outras coleções. Segundo Lima (2017), mesmo obras como pinturas requerem do museu, da instituição, um olhar determinado para cada obra, e o mercado da performance ainda é muito lento, principalmente por lidar com trabalhos vivos, mas o artista deve fazer seu trabalho, sob seu ponto de vista.

Outro questionamento de Lima (2017) é que o artista tem que sobreviver, e consequentemente até se adaptar, contudo "você precisa lidar com o museu, ou você precisa sobreviver, precisa pagar as contas (...), você opta por fazer parte do mercado, a não ser que você não queira" (LIMA, 2017, p. 9). O mesmo ocorre em relação à catalogação, que está atrelada ao mercado. Por exemplo, a obra "Palhaço" (figura 29), 
que pertence ao acervo do MAM-SP, a artista negociou os termos de catalogação, mesmo porque essa foi a terceira aquisição da mesma artista por essa instituição:

Porque o museu de uma forma de ser ativo, de querer ter essa coisa do primeiro, compra uma performance e justamente escolhe o artista que não chama aquilo de performance, mas eles querem comprar performance. E aí então, aquilo faz parte da história porque eles também vão falar assim, "não, porque nós fomos os primeiros a introduzir", sim, é isso mesmo e são (LIMA, 2017, p. 10).

As reflexões de Lima indicam que a inclusão de performances dentro dos museus, brinda a instituição com status, além das questões estéticas que agregam valor ao acervo, porém as negociações acontecem em sigilo. Quanto ao valor das obras, exceto o "Parangolé", de Lorival Cuquinha, que divulgou o valor da obra, os demais artistas mantêm segredo.

Laura, que já vendeu obras no exterior e assina duas no Inhotim e uma no Museu de Arte da Pampulha (MAP) não revela os valores dos contratos. (...) Manter o sigilo parece ser uma questão mercadológica. "O valor é dado a partir de uma média da importância histórica do artista ou do grupo. Também é levado em conta se a obra é premiada, se ela participou de exposições importantes... "O valor é subjetivo", esclarece o artista João Angelini, do Grupo Empreza. (...) a única indicação é que as angariadas, em 2005, pelo Inhotim - "Dopada" (1997) e "Marra" (1996) - "foram mais caras" (OLIVEIRA, 2016, p. 4).

Artistas como Ianês tem uma percepção particular, acredita que desde Duchamp e os dadaístas, entre outros movimentos artísticos que metaforizaram o objeto de arte, o mercado se adaptou para assimilar obras imateriais. Com a performance o caminho foi similar, entrando com rigor nas coleções. Um exemplo para Ianês é a performer Marina Abramović que documenta seus trabalhos por meio de fotos e vídeos, mas estes acabam sendo substratos comerciais, obras vendáveis, contudo obras que funcionam integradas e dependem do público, não deveriam ser tratadas como "produto de mercado, e sim um registro histórico, um registro daquela ação" (IANÊS, 2016, p. 7).

As feiras de arte, em relação a performances, apresentam resistência de acordo com Ianês (2017). Ianês foi o primeiro performer a participar da SP-Arte e lembra que a aceitação do público foi incomum e por não enxergar se concentrou em ouvir os comentários: "o quê que ele está fazendo aqui? Aqui não é lugar para isso, aqui é lugar de objeto de arte com preço" (IANÊS, 2016, p. 8), modestamente, o artista afirma ser um gladiador em parceria com galeristas, a favor da inclusão de performance no sistema da arte e sua devida manutenção, afinal o mercado absorveu a linguagem, apesar de certa relutância e conservadorismo.

De maneira especial, grandes corporações financiam arte contemporânea, estreitando a relação entre público e privado no âmbito das artes. Nesse nicho, a indústria de luxo tem se evidenciado, projetando suas marcas, em parceria com a arte, que 
promove museus-espetáculos, como ocorreu com o grupo $\mathrm{LVMH}^{32}$, que criou um centro de arte autônomo, a Fondation Louis Vuiton pour La Céation, em 2010, que se tornou atração turística semelhante é a postura da Chanel, que em algumas de suas sedes, não decora os ambientes com obras consagradas, mas as encomenda dialogando com a marca, ratificando a exclusividade e ostentação da grife (BOLAÑO, 2010).

No Brasil, instituições financeiras como Caixa Cultural, Itaú Cultural e Centro Cultural Banco do Brasil são referências de parcerias entre arte e mercado, essas instituições como compromisso ético com o país, faz uso da responsabilidade social e aplica recursos oriundos de renúncia fiscal (imposto devido na fonte), na divulgação e apoio à cultura e arte, principalmente por meio de exposições e ocupações artísticas. $\mathrm{O}$ mesmo ocorre com salas comerciais de cinema à saber: Espaço Itaú de Cinema e Caixa Belas Artes de Cinema, que utilizam o nome da instituição apoiadora, nos espaços, ratificando a parceria, tendência que vem crescendo no país.

Uma questão difícil de definir é preço de uma obra de arte, mesmo porque ela não é como ações de uma empresa ou objetos manufaturados. Normalmente é peça única e sua valoração tem variações referentes à arte, ao artista e ao período de sua criação e circulação no mercado. Mas, variações do próprio mercado e o perfil econômico do hipotético comprador (BENHAMOU, 2007) são cartas presentes nessa mesa de negociação, em um jogo que é difícil prever o resultado.

Alcimar Frazão (2016) tem uma visão muito clara da mecânica do mercado, na qual a instituição é pautada por ele, quando deveria ser o inverso. O SESC tenta alinhar esse caminho, propondo exposição de artistas cuja linguagem apresente algo cujo debate pode reverberar no mercado, sempre com foco no debate estético. Contudo, acredita que o mercado não deva ser "termômetro para discutir arte" (FRAZÃO 2016, p. 9), pois muitos artistas consagrados pelo mercado têm obras discutíveis quanto à relevância do seu momento histórico e social.

\footnotetext{
32 “O grupo LVMH - Moët Hennessy Louis Vuitton, o maior conglomerado de produtos de luxo do mundo, do qual a Chandon faz parte, nasceu em 1987, resultado da união dos grupos franceses Louis Vuitton (fundado em 1854) e Moët Hennessy (procedente do champagne Moët \& Chandon, fundado em 1743, e do cognac Hennessy, de 1765). Com a união, passaram a pertencer a um só grupo os champagnes Don Pérignon, Frug, Moët de Chandon, Veuve Clicquot, dentre outros nomes fortes do segmento de bebidas de luxo. $\mathrm{O}$ grupo francês também atua nas áreas de moda, perfumes e cosméticos, relógios e distribuição seletiva. Entre as suas principais marcas estão Loius Vuitton, Christian Dior, Givenchy, DKNY, Fendi, Kenzo, TAG Heuer e a Chandon" (CHANDON, s.d.).
} 


\title{
3.3 COLECIONAR PERFORMANCES: UM NOVO PARADIGMA NO SÉCULO XXI
}

\begin{abstract}
A história mostra que o hábito de colecionar parece ter surgido com o próprio ser humano. No campo da arte, talvez tenham sido os gregos os primeiros a inventariar objetos artísticos. Com a decadência da Grécia e de Roma, a Igreja tornou-se a grande sucessora relativamente à coleção de obras de arte, posição depois disputada pelos nobres, com o surgimento do mecenato, e, mais tarde, pela emergente burguesia (PINHO, 2009, p. 194).
\end{abstract}

Colecionadores aparecem na História da Arte desde muito cedo: mecenas, apreciadores e investidores, clero, nobreza, burguesia e parcela da sociedade abastarda têm praticado o colecionismo, seja pela apreciação, pelo status, ou para investimento. Esse universo vem demonstrando estar a pleno vapor, principalmente em países detentores de mais riquezas materiais. No Brasil, essa tendência vem crescendo modestamente, apontando um futuro promissor aos artistas, compradores, colecionadores e instituições de arte.

O advogado e colecionador Sergio Carvalho, em 2015, comprou a obra "Maleducação 33 " do grupo Empreza (figura 42), uma encenação na qual o grupo, com as mãos amarradas, utiliza próteses que dificultam a mastigação em um banquete. A obra pertence à coleção particular, se tornou propriedade, e Sergio tem os direitos de encenação da obra. O advogado eclético tem no seu acervo de mais de 1.300 objetos, como pinturas, esculturas, fotografias e performances. Carvalho possui também, do mesmo grupo, “Tríptico Matera"34”, comprada em 2013. É interessante salientar que a relação do advogado com os artistas é bem próxima, podendo indicar ser isto um facilitador da negociação desta linguagem artística, ainda não comum no Brasil.

\footnotetext{
33 A performance "Maleducação" pede no mínimo cinco dos dez integrantes do Grupo EmpreZa, para execução. Consiste no grupo sentado em torno de uma mesa de jantar requintada, na qual eles se vestem a moda de dress code corporativo. Eles bebem, conversam, distribuem gentilezas aos presentes e compartilham a refeição. Contudo, uma das mãos fica amarrada com a mão de outro colega, dificultando a movimentação. Outro ponto nevrálgico é o fato de todos os performers usarem uma espécie de aparelho ortodôntico, que mantêm as bocas e mandíbulas comprometidas, que remetem a certo sadismo (SCARTEZINI, 2017).

34 "Tríptico: A obra Tríptico (ou Tríptico Matera) consiste na ação de três ou mais performers. Cada artista terá dois baldes de metalon (típicos para içamento de concreto), sendo um deles contendo de um litro de cola branca, além de um conjunto de materiais específicos - que variam, mas devem ser capazes de produzir resíduo material sólido em pó ou granulados. Cada um dos performers irá trabalhar uma das matérias em gestos de pilar, macerar, ralar, raspar, queimar ou qualquer outra ação que fragmente o material até virar pó, grão ou outro resíduo sólido que aproxime das características anteriores (esse gestual poderá ser feito com uso de ferramentas e utensílios à escolha do artista). Após o tratamento, todo o material é depositado no balde vazio. Os artistas, fazendo uso de um pincel grosso, passam a cola branca no rosto, cabeça e tronco. Em seguida despejam todo material tratado em suas cabeças, impregnado seus corpos. Ao final da ação, os três se posicionam lado a lado e se esfregam uns nos outros (a partir da cabeça), promovendo a mistura dos materiais (e sua pictoriedade) entre os seus corpos" (SIQUEIRA, 2018).
} 
A aquisição de Sergio Carvalho aponta para algo no mínimo inusitado. O colecionador não leva para seu acervo um objeto que poderá colocar na parede ou sobre um pedestal, ele agregou a sua coleção um documento, papéis com a descrição de como deve acontecer uma reencenação e o direito de realizá-la.

Figura 42 - "Maleducação", Grupo Empreza, 2015

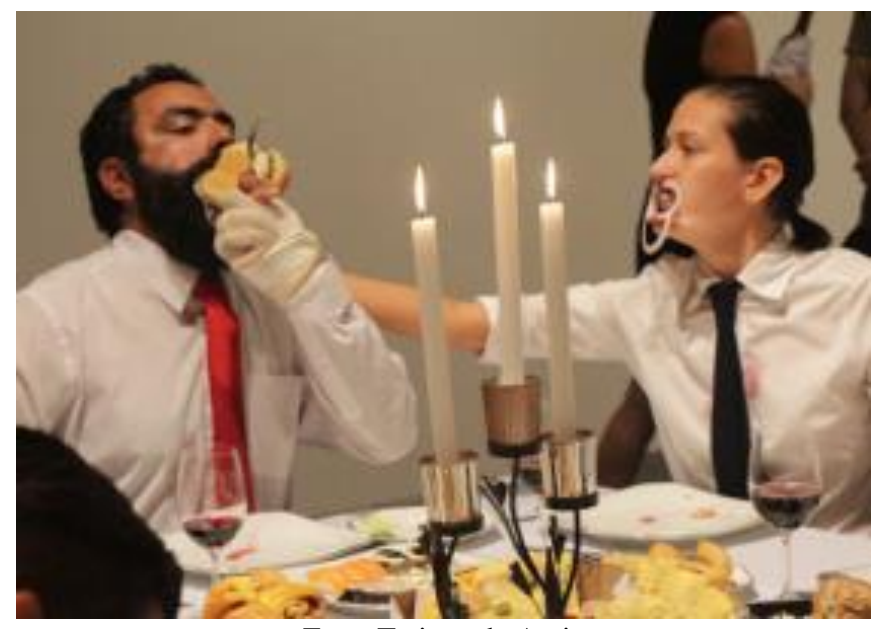

Foto: Tatiane de Assis

Fonte: http://performancecorpopolitica.net/?gallery=empreza
Figura 43 - "Tríptico Matera", Performance corpo política, Grupo Empreza, 2013

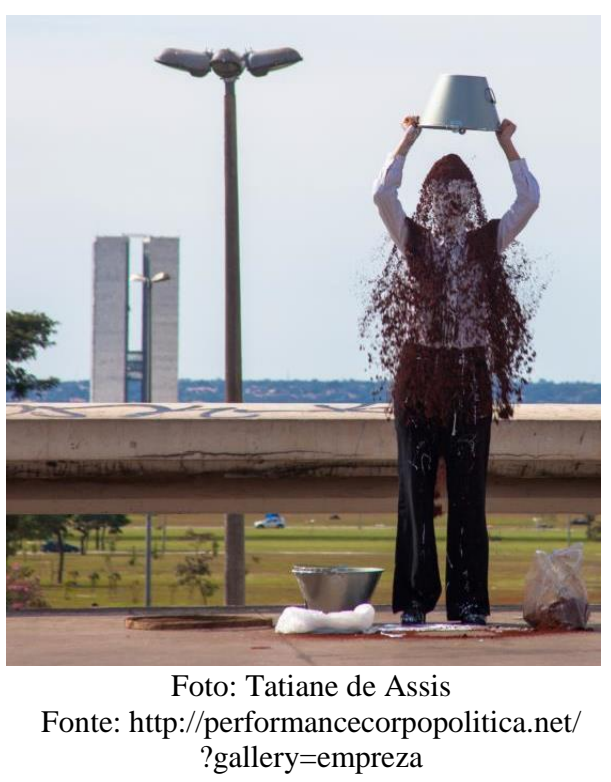

A exposição "Terra Comuna", de Marina Abramović, que aconteceu no SESC Pompéia, em 2015, foi tão impactante como qualquer exposição de pintura e escultura, que abarca estruturas bem complexas, climatização e manuseio de obras únicas. Essa performer utilizou a plataforma vídeo, em muitas ações, na exposição, já que não estava presente durante todo o evento. O supervisor do Núcleo de Artes Visuais Alcimar Frazão (2016t, p. 12), do SESC Pompeia, relatou que a transação das obras nessa plataforma, com trabalhos da trajetória da artista, apresentou algumas facilidades, como transporte e seguro, mas o cuidado com a obra foi o mesmo, "porque ainda sendo digital é obra, ela é preservada, é igual como se fosse uma pintura".

$\mathrm{O}$ acervo era da própria artista, que acompanhou a montagem e ao término da exposição, as mídias e o material retornaram ao seu acervo pessoal. O mesmo ocorre quando colecionadores cedem pinturas e esculturas para serem expostos e, ao fim do evento, as peças voltam à origem.

Quando um colecionador compra uma performance, além do documento com descritivo da performance, que normalmente detalha a encenação, ele fica com os direitos da obra. Eventualmente, quando for encenada, será necessário negociar com o colecionador, porque o artista abriu mão do direito de propriedade. Será necessário 
constar nos créditos do evento o nome do criador e do proprietário, e talvez essa questão seja um elemento de valoração da performance: o status do proprietário.

A coleção particular do advogado Sérgio Carvalho foi motivo da exposição no Museu Nacional Honestino Guimarães ${ }^{35}$, ou Museu Nacional de Brasília, com a exposição "Contraponto" (2017), que sob curadoria de Tereza de Arruda apresentou 33 artistas diferentes. Importante ressaltar que Carvalho possui séries inteiras de alguns artistas "mantendo assim a integridade e a unidade da obra original" (SCARTEZINI, 2017, p. 1). A abertura aconteceu com a reperformance "Maleducação" do Grupo EmpreZa, pertencente à coleção, que será encenada sempre que Carvalho desejar, já que detém o direito sobre a obra, em sintonia com o grupo. O colecionador tem uma trajetória de expor ao público sua coleção, com mostras em São Paulo, Rio de Janeiro, Belo Horizonte e em Brasília (no Museu dos Correios) (SCARTEZINI, 2017).

O cinema comercial tem uma relação próxima, pois o criador, produtor e diretor de um filme para terem sua obra nas telas de cinema precisam das distribuidoras, que intermediam esta ação. Normalmente os direitos comerciais do filme ficam com as distribuidoras, e enquanto o contrato for do distribuidor, o filme será exibido nas salas comerciais que têm que pagar à distribuidora. Finalizado o contrato, o filme sai de cartaz e poderá ser vendido para outro suporte de exibição. A tela é onde o filme existe e dialoga com o público (SANTOS, 2016), afinal o filme são rolos de película, ou mídias digitais, objetos sem vida que só conseguem expor ao mundo suas metáforas, conceitos e ideias, quando projetados. A comercialização dessa linguagem de massa tem sua lógica e de alguma forma conversa com a encenação da performance, pois ambas acontecem no espaço da projeção ou exposição.

Colecionar performance tem outros aspectos, como destaca Juliana Moraes (2016). Ela recorda a compra de uma performance do Tino Shegal por um casal milionário, por um valor substancial, na qual a encenação consistia em oferecer um jantar, e no final o marido e esposa vão para o quarto, trocam suas roupas, ele com a dela e vice-versa, descem e ao final do jantar pronunciam: "Esta é uma obra do Tino Sehgal" (MORAES, 2016, p. 9). Para Juliana (2016, p. 10), o que importava para o casal era o status que isto representou, como uma marca, uma grife: "No campo das artes visuais isto sempre aconteceu, não é novidade, (...) os colecionadores investem nos artistas que eles

\footnotetext{
35 O Museu Nacional Honestino Guimarães é uma das tantas impressionantes obras de arquitetura encontradas na capital federal. Projetado por Oscar Niemeyer em parceria com Lúcio Costa, o edifício tem 14 mil metros quadrados de espaços dedicados a galerias, serviços e áreas de apoio. A expressão minimalista do edifício - uma semi esfera perfeita e uma proeminente rampa de acesso - rende um caráter surrealista à obra situada na Esplanada dos Ministérios (URIBE, 2016).
} 
acham que vão render dinheiro, então eles investem como se fosse uma bolsa de valores, e a performance é um pouco isso".

Moraes (2016) ainda esclarece que até meados dos anos 2000 tinha poucos registros e acervos de performance no Brasil. Os artistas não tinham esta preocupação, o que dificulta as pesquisas na área. Há pouco tempo, os artistas brasileiros demonstraram interesse em registrar seus trabalhos, e alunos de universidades têm este tema como eixo central.

Ciotti (2017) compreende que o termo "acervo" é aberto, e possui vários entendimentos: o olhar do artista; do público; da instituição; contudo, ela tem visão de artista e pesquisadora, o que pode ter vários desdobramentos. Inclusive a obra poderá se tornar imã de geladeira, um livro, conferência, ou curadoria, mas as mediações e a documentação são profundamente significativos.

Convencionalmente, os acervos foram pensados e estruturados a partir de "suporte ou de linguagem, acervo de pintura, acervo de gravura, acervo de fotografia, acervo de escultura" (PITTA, 2016, p. 2), que apresenta certa restrição, principalmente no campo das artes modernas e contemporâneas. Por não darem conta dessa abordagem mais ampla e aberta, a catalogação acontece por vezes por meio de aproximação, por exemplo, pintura com a fotografia, mas devido a essa limitação, a própria produção artística amplia polêmicas de como colecionar, preservar determinadas obras, e a performance favorece esses desafios, devido seu caráter (PITTA, 2016, p. 2).

De acordo com Laura Lima (2017), que não usa o termo performance para suas ações, e habitualmente permite que suas ações sejam executadas por outros artistas, existe uma "certa" leviandade dela por não executar as ações, por desejar incorporar uma identidade na obra, mas essa característica da artista sem dúvida facilita a reencenação de suas obras, tombadas em acervos de instituições de arte.

Lima (2017) atualiza sempre que possível suas orientações por acreditar que suas obras estão vivas, mesmo sem ter convicção de constar isso no contrato junto à instituição. Contudo, a artista crê que as instituições carecem de expandir a abordagem da catalogação que, por vezes, rotula, blinda a obra com determinada terminologia, que pode gerar algumas adversidades, por falta dessa flexibilidade, como também tem convicção, que as orientações não são só para os artistas que irão reperformar, mas também para as instituições.

Evidente que cada performance, cada artista terá uma relação, uma particularidade com o acervo e a instituição, característica da arte contemporânea. Para o artista que cria uma obra a ser performada por outro, isso pode ser um elemento facilitador para a 
instituição, mas o artista acaba por ser também um regente, no qual o solista é um terceiro (CUQUINHA, 2017).

Esse ponto de vista é congruente ao do Maurício Ianês (2016), que endossa essa abordagem com outras manifestações artísticas, e lembra que desde o Modernismo, com o mictório de Duchamp, as instituições tiveram que se adaptar quanto ao acervo, como a conservação de obras de arte, que quebraram padrões e paradigmas da ideia de obra de arte. Ele se recorda de uma pintura de Nuno Ramos, em uma bienal, cujos pedaços da obra começaram a cair: "o lugar do objeto de arte dentro da história (...) dentro de um acervo histórico de uma instituição" (IANÊS, 2016, p. 4), traz novos questionamentos para as instituições, que terão que lidar com cada caso, cada obra e cada artista.

A inclusão dessas obras em acervos, portanto, implica desde logísticas de contração de artistas para execução até divergências políticas, morais e a comercialização dos registros.

Colecionar performance, arte da ação, do corpo, traz em seu repertório diversos aspectos, além da interação com o público. O registro, para sua reencenação, plataformas em vídeo, para alguns se trata de acervo e para outros têm aspecto museológico. Finalmente, a indefinição de padrões e normas são demonstrações de que há um campo em debates apontando para o futuro, mas a comercialização e institucionalização da expressão hoje no Brasil é fato concreto. 


\section{CAPÍTULO IV - INVENTÁRIO DE ACERVOS DE PERFORMANCE EM INSTITUIÇÕES EM SÃO PAULO/SP}

Este capítulo apresenta um inventário das performances existentes em acervos públicos em São Paulo, como obras integrantes das coleções.

Ao todo são 5 (cinco) obras existentes nos museus de São Paulo até a finalização deste estudo (abril de 2018), cujas informações foram obtidas no site dessas instituições ou com os entrevistados para esta dissertação.

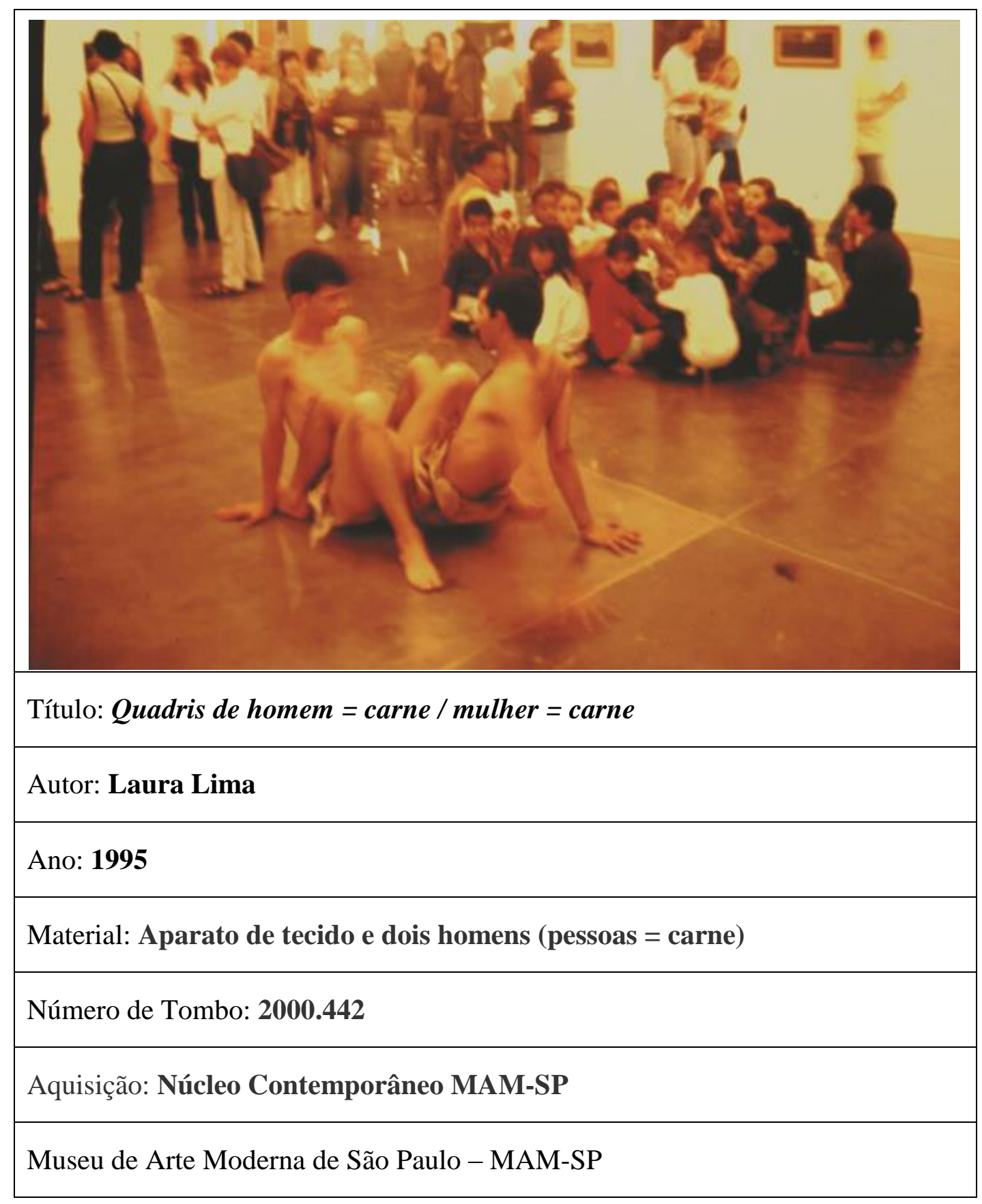

Obs.: Informações retiradas do site do Museu de Arte Moderna de São Paulo, nos acervos de performances. 


\begin{tabular}{|l|}
\hline \\
\hline Aítulo: Bala de homem = carne / mulher = carne \\
\hline Autor: Laura Lima \\
\hline Ano: 1997 \\
\hline Material: Bala, aparato de metal, cadeira, um homem (pessoa = carne) \\
\hline
\end{tabular}

Obs.: Informações retiradas do site do Museu de Arte Moderna de São Paulo, nos acervos de performances. 


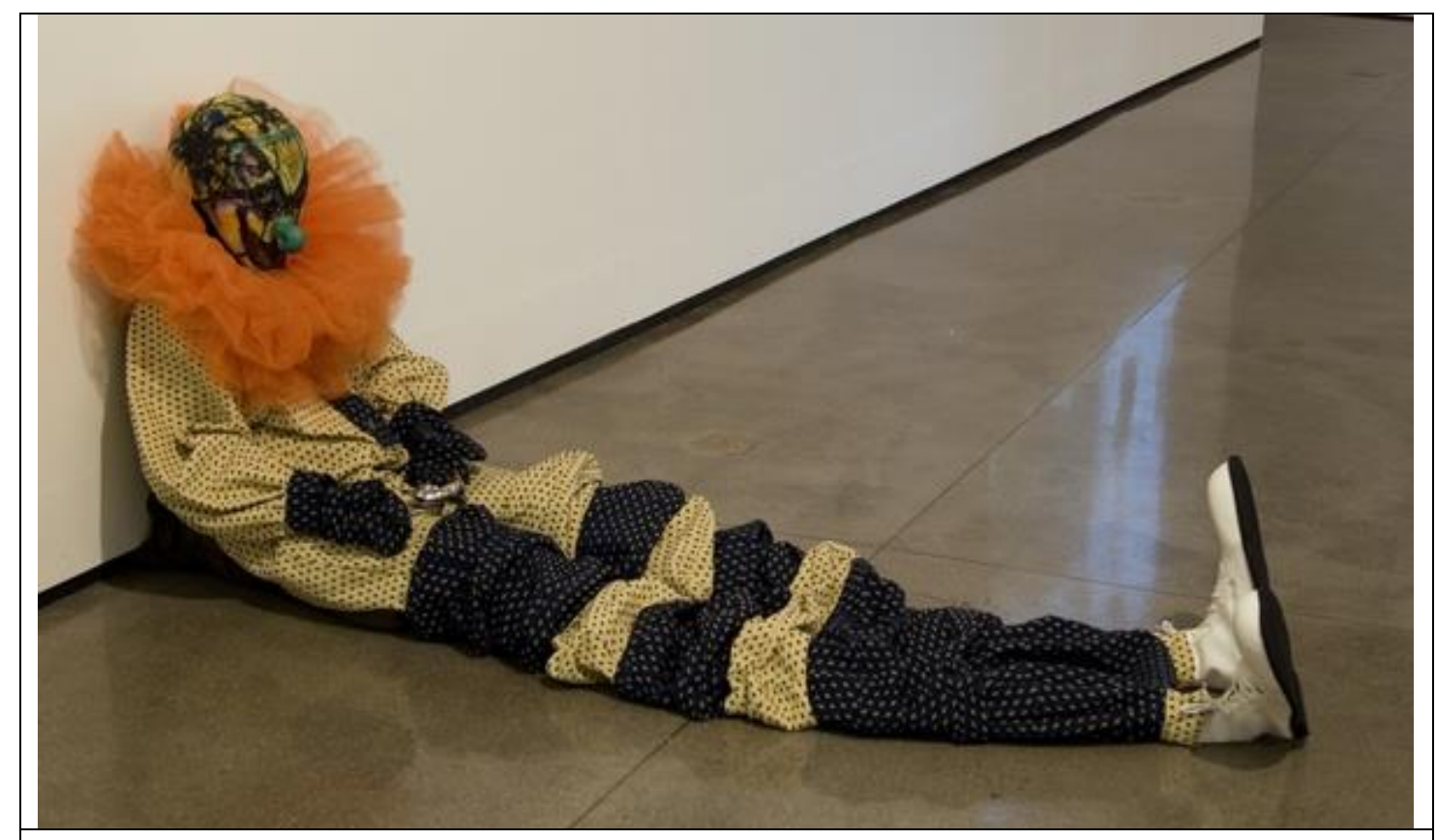

Título: Palhaço com buzina reta - monte de irônicos

Autor: Laura Lima

Ano: 2007

Material: Máscara de papel machê e lápis óleo, roupa de palhaço de tecido, colarinho de tule, sapatos de couro, buzina, tubos de PVC

Número de Tombo: 2008.030-000

Aquisição: Prêmio Aquisição Telefonica - Panorama 2007

Museu de Arte Moderna de São Paulo - MAM

Obs.: Informações retiradas do site do Museu de Arte Moderna de São Paulo [MAM-SP], nos acervos de performances, com exceção dessa obra, que aparece junto das outras obras de Laura Lima, como peça de arte. Quando entrevista, Laura informou, que a obra não foi catalogada como performance, a seu pedido, devido o elemento surpresa, que a ação pede. 


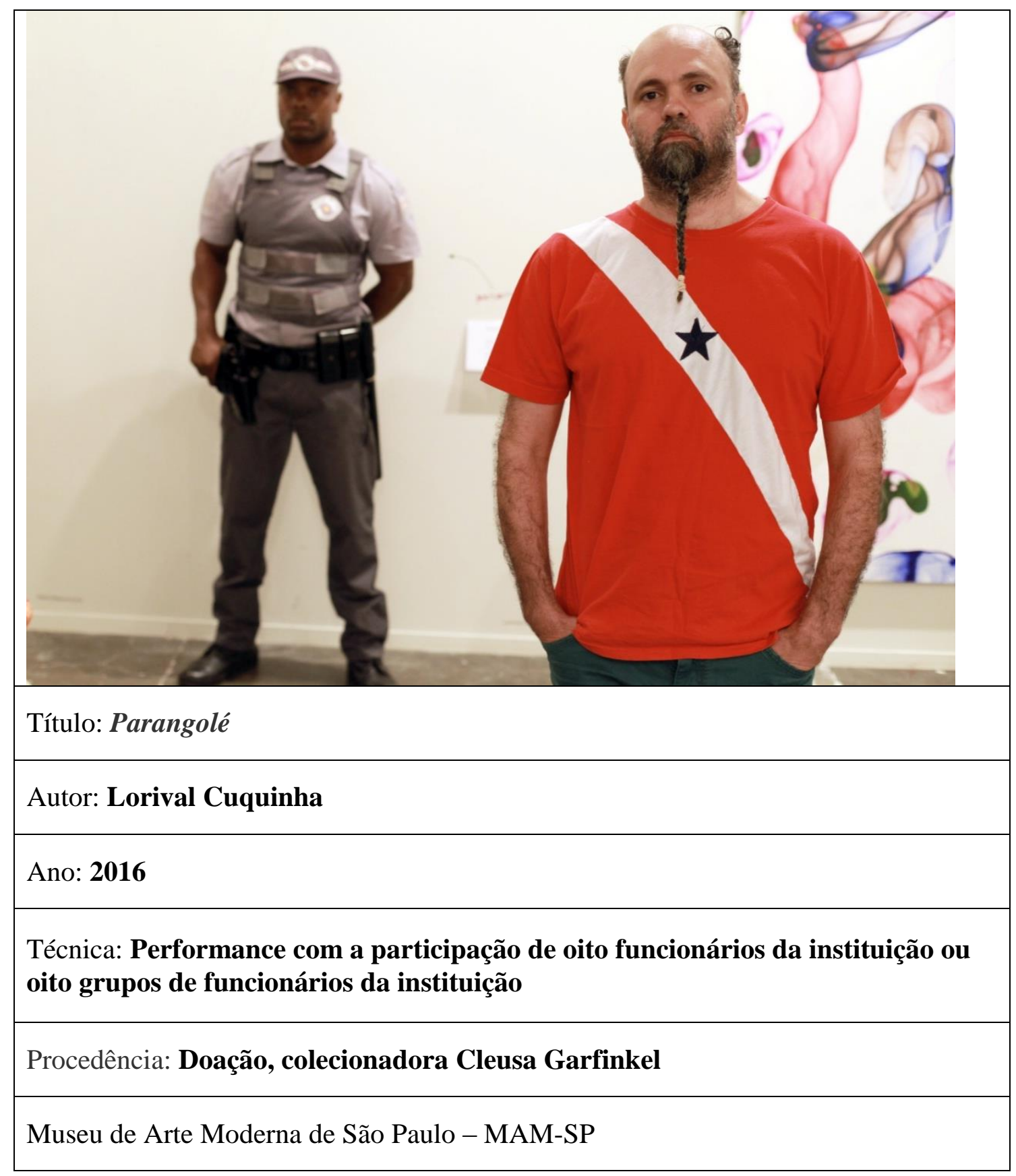

Obs.: A obra ainda não consta no site da instituição.

Foto: http://jconline.ne10.uol.com.br/canal/cultura/artes-plasticas/noticia/2016/04/25/cuquinha-umvendedor-de-gestos-232709.php 


\begin{tabular}{|l|l|}
\hline & \\
\hline
\end{tabular}

Obs.: Informações retiradas do site da Pinacoteca do Estado de São Paulo, em acervos/obras do artista Maurício Ianês. Para mais informações, acessar: <http://pinacoteca.org.br/acervo/obras/>. 


\title{
CONSIDERAÇÕES FINAIS
}

Neste capítulo são apresentadas as conclusões e argumentos alcançados para atingir aos objetivos propostos para este estudo, na tentativa de justificar a realização desta dissertação, ao mesmo tempo em que apontará pesquisas futuras nessa área, ainda pouco desenvolvida no país, já que os acervos de performance ainda não existam em grande escala.

\begin{abstract}
Ao longo de grandes períodos históricos modifica-se, com a totalidade do modo de existir da coletividade humana, também o modo de sua percepção. A maneira pela qual a percepção humana se organiza - o meio em que ocorre não é apenas naturalmente, mas também historicamente determinado (BENJAMIN, 2014, p. 56).
\end{abstract}

Na performance, como em outras linguagens que fazem uso do corpo do artista, como o teatro e a dança, o artista pode ter uma ação individual ou com outros corpos em uma atividade coletiva, ou até mesmo criar uma obra para que outros artistas ou outros corpos a execute; além de materiais e diversos tipos de linguagens que conversam entre si, apresentando informações que compõem um novo panorama e entram em contato direto com o público. Por vezes, essas linguagens são efêmeras, assim como é a realidade do artista que a executa e o contex to em que está inserida.

A performance sob o olhar de alguns artistas e curadores participantes ${ }^{36}$ deste estudo não pode ser reproduzida, e se o for, poderá ser considerada outro produto, outra obra, pois cada momento é único.

Em sua trajetória, essa linguagem possuiu outras denominações até assumir a terminologia "performance", ligada basicamente à ação do corpo do artista que encena e interage diretamente com o público, com metáforas, influências e referências tão singulares, dificultando sua definição. Outro dado a se considerar é que a performance pertence a um contexto histórco, social e político. Ela deu os primeiros sinais concretos de vida com as vanguardas do século XX, tais como: Dadaísmo, Futurismo, Surrealismo, Bauhaus, e desdobramentos de outras manifestações, como body art, action painting, e se afastando no tempo, outras referências oriundas do Oriente, como o teatro Kabuki e Nô, por apresentarem interfases das artes tradicionais, de grande impacto visual e uso do corpo, como ferramenta e personagem da ação, também ajudaram a performance a

\footnotetext{
${ }^{36}$ Alcimar Frazão, coordenador do SESC Pompeia; Cauê Alves, coordenador de Artes Visuais do Centro Universitário Belas Artes de São Paulo; Fernanda Pitta, curadora da Pinacoteca de São Paulo; Juliana Moraes, performer e professora de performance Centro Universitário Belas Artes de São Paulo; Laura Lima, performer e artista plástica; Lorival Cuquinha, performer e artista plástica; Marcos Gallon, diretor da Mostra Verbo de performances da Galeria Vermelho; Maurício Ianês, performer e artista plástico; Naira Ciotti, performer e docente da Universidade Federal do Rio Grande do Norte.
} 
encontrar seu espaço. É considerável apontar os rituais tribais, os mistérios medievais e até mesmo os espetáculos do século $\mathrm{XV}$, de variedades, e as atividades circenses, todas essas manifestações contribuíram para consolidação da performance como expressão artística.

Contudo, a performance vem de uma história ligada a anti-arte contestando as instituições. Envolve vários campos do conhecimento, e por ser caracterizada uma expressão híbrida ou de fronteira, em parceria com outras linguagens, enfrenta questões relativas ao pertencimento dos acervos em instituições públicas e/ou coleções particulares.

Provavelmente o maior dilema em incluir performance nos acervos, esteja no fato de ela ser imaterial. Para resolver esse problema, um dos caminhos apontados por especialistas, artistas e curadores está nos registros, sejam estes documentos que a descrevem e informam como aconteceu a performance, possibilitando a reencenação ou reperformance; além do certificado de compra e venda, determinando os direitos autorais do comprador, do proprietário. Os resíduos, que são os substratos ou objetos que ficaram da ação poderão ser expostos separadamente ou serem transformados em instalações; as fotos, que congelam e registram o momento, por vezes podem ser o resultado final de algumas performances, sendo passíveis de ser comercializado. E finalmente o vídeo, que devido à verossimilhança, descreve a ação em movimento, e como a fotografia, pode ser o resultado de uma ação: a foto performance e a vídeo performance. É fundamental destacar que alguns artistas não permitem o registro de suas ações e, por vezes, a oralidade é o caminho para a reprodução do trabalho desses artistas.

Algumas performances permanecem nas páginas da história devido ao seu registro, já que a ação aconteceu em um tempo e espaço restrito, como apontado nesta pesquisa. A performance Shoot, de Chris Buden, em 1971, é um exemplo emblemático da importância do registro como elemento que permite a divulgação, pesquisa e conhecimento de performances, principalmente aquelas que tiveram uma única exibição.

O acervo de performance é um entendimento contemporâneo, mas ao se investigar o hábito de colecionar parece ter surgido quase com o próprio ser humano. A história comprova que, no campo da arte talvez tenham sido os gregos os primeiros a inventariar objetos artísticos, chegando até os dias atuais essa prática de colecionar, apreciar, contemplar e comercializar arte, tanto no âmbito privado quanto público, o que já se tornou um empreendimento comum na sociedade moderna.

Independentemente do período histórico, a arte sempre esteve e estará presente na vida da sociedade, por ser essencial em todas as ações humanas (CAUQUELIN, 2005). 
Ou seja, a arte e o homem vivem em simbiose, construindo e transformando o tecido cultural e social.

Estabelecer a transversalidade entre as artes, em um mundo globalizado, significa propõe um diálogo entre as múltiplas linguagens, plataformas, suportes, com o propósito de estabelecer novas leituras. A arte contemporânea possibilita e indica caminhos, utiliza inclusive das mídias digitais, que estão disponíveis, no dia a dia do homem contemporâneo, ao mesmo tempo em que é suporte e meio de expressão, porém essa pesquisa ainda requer outras investigações.

É importante ter consciência de que "o olhar não é um ato passivo, ele não faz que as coisas permaneçam imutáveis" (ARGAN, 1993, p. 235). Nesse sentido, tanto o olhar do artista, das instituições quanto do público devem ser aprofundados e ampliados. As instituições precisam levar em consideração os fatores culturais, sociais e políticos, as questões relativas ao mercado e acabam tendo que assumir uma posição, quanto aos valores que seu acervo e suas exposições irão apresentar.

É evidente que uma exposição ou encenação, de um determinado artista pode posicioná-lo no mercado, principalmente em uma instituição, que traduza a seriedade quanto à discussão da linguagem inserida no cenário cultural. Ou seja, de alguma forma tende a repercutir no mercado.

Qualquer manifestação artística precisa entender seu mercado, suas necessidades, para viabilizar suas práticas, contudo, a arte não deve viver em função do mercado, sendo a estética, a expressão, a válvula motora e o bem maior para o artista. A arte deve ser a possibilidade de dialogar com seu público, todavia o artista como qualquer indivíduo necessita sobreviver e não pode se desconectar do mercado. Esta lógica por vezes pode asfixiar o fazer artístico, no que ele tem de mais profundo. A arte é um campo de livre expressão e o mercado tem proporcionado condições aos artistas para desenvolverem seus trabalhos, em muitos casos, mas talvez uma das tarefas mais difíceis para um artista, esteja em definir esse equilíbrio.

\footnotetext{
Por um lado, a história da performance clama por independência e autonomia, liberdade para criar livre do peso imposto pelo passado; por outro lado depende de um encadeamento cronológico que sinalize para noções de transformação e evolução que seja coerente e faça sentido, tanto para os próprios artistas como para o sistema de arte, seus agentes e seus espectadores (OLIVA, 2015, p. 90).
}

Um colecionador ou comprador quando adquire uma performance, além do descritivo da obra, que normalmente detalha a encenação, em alguns casos determina o biótipo, espaço cênico, enfim, apresenta um registro documental da obra. Ele fica com os direitos da obra e, eventualmente, quando for (re)encenada será necessário negociar com o colecionador ou comprador, porque o artista abre mão do direito de posse. Como ocorre 
com pinturas e esculturas, ou qualquer outro objeto de arte que traz o nome do autor e do colecionador, na performance ocorre o mesmo, pois o proprietário/colecionador deve ser creditado, e esse argumento pode resultar em uma válvula de propulsão dessa linguagem, ao transferir ao colecionador status de personagem no universo das artes.

Todas essas abordagens ratificam a importância da linguagem e seu devido espaço em coleções e acervos. A performance até integrar um acervo passa por uma triangulação: o artista, que cria e apresenta um descritivo/orientação da obra a ser reencenada; a galeria, que normalmente representa o artista e viabiliza a comercialização da obra, bem como as feiras de arte, que têm objetivos bem claros de compra e venda de obras de arte; e, finalmente, a instituição que recebe a obra e deve catalogar, reperformar, conservar, expor, no intuito de oportunizar ao público o acesso à mesma, permitindo o acesso e ampliação à sua divulgação. Evidentemente, são muitos os meios utilizados pelo artista e pelas galerias, que o representam para efetuar sua comercialização, dentro do sistema de venda e compra que poderá posicioná-lo no mercado.

$\mathrm{O}$ artista que tem visibilidade no contexto e um plano de marketing adequado tende a conseguir patrocínio para desenvolver suas atividades, permitindo estreitar relação com o seu público, e consequentemente a ter mais espaço no mercado e em acervos e/ou coleções.

Um questionamento ainda fica em aberto: os registros em papel, ou vídeos e fotos são imparciais? Ou podem levantar outras questões, outras abordagens? Só o tempo permitirá responder.

Uma condição parece-nos relevante quando se integra uma performance em uma coleção ou um acervo, que é a possibilidade de reperformar a ação, afinal, ter um documento que atesta a posse da obra não é o suficiente para sua fruição, contemplação e pesquisa, mas especialistas afirmam que cada encenação é única e os registros não são suficientes para abarcar o todo da obra, suas metáforas, simbologias e significados.

Desde a Grécia antiga até o século XXI, o público vai ao teatro e ao cinema assistir e apreciar várias obras, dentre estas os clássicos, que mesmo que conheça a narrativa e o desfecho, ainda assim o público marca sua presença nesses espetáculos. Talvez o mais importante esteja na forma, na maneira como a história é contada, independente do conteúdo previamente conhecido. A reperformance parece ter herdado essa qualidade, talvez o mais importante seja como ela será reencenada, como será o diálogo com o público, como será a curadoria. Essa tarefa nada fácil e complexa é mais um recorte dos tentáculos que arte consegue abraçar, e por vezes transforma momentos cotidianos e corriqueiros em acontecimentos transcendentais, sistematicamente únicos. 
Por questões como essas, tudo indica que os colecionadores estão apostando no mercado de performance, devido ao aumento da comercialização entre galerias, feiras e instituições de arte.

Ao se pesquisar os acervos de performance em São Paulo, Brasil, uma constatação não muito animadora nos é colocada: até os anos 2000 poucas obras possuem registros, e em acervos o resultado é quase nulo, possivelmente porque os artistas não tinham essa preocupação (MORAES, 2016), o que gera dificuldades no campo acadêmico, no entanto, abre perspectivas para este e outros estudos.

Em arte tudo é possível e está em plena transformação, as primeiras duas performances a pertencerem a um museu ocorreram em São Paulo, no Museu de Arte Moderna, em 2000, com obras da artista Laura Lima, que além de inovar, possibilitou uma mudança de paradigma quanto ao ato de colecionar. De 2000 até o momento (abril de 2018) já são cinco as performances que pertencem a acervos em São Paulo: o MAMSP com as obras de Laura Lima, que em 2007 agregou outra ação "Palhaço com buzina reta - monte de irônicos", da mesma artista e, recentemente em 2016, a performance "Parangolé", de Lorival Cuquinha, (que não constava no site da instituição quando da finalização desta dissertação, por estar em processo de tombamento), e a obra "O Nome" de Maurício Ianês, adquirida pela Pinacoteca de São Paulo, em 2015.

Ainda nesse contexto, cabe destacar a participação de Tadeu Chiarelli que, em 2000, respondia pela curadoria do MAM-SP, quando da aquisição das primeiras performances em São Paulo e no Brasil. E em 2015 assumiu a direção geral da Pinacoteca de São Paulo, período de aquisição da performance de Maurício Ianês. Estas constatações podem indicar que a curadoria e a perspectiva de um administrador podem ser o diferencial na construção de acervos de instituições de arte, notadamente de performances.

Essas questões podem sugerir, mesmo que não amplamente, que os registros de performances, a curadoria, o mercado e a intensa criatividade de muitos artistas podem alimentar a inclusão da performance em acervos e coleções em cidades como São Paulo, garantindo ao público interessado, o acesso a essa linguagem tão peculiar e emocionante.

Instituições como o MAC-USP possuem apenas acervo fotográfico e videográfico de performances, assim como a Galeria Vermelho que comercializa a linguagem, e só tem arquivos da expressão nos mesmos formatos: fotografia e vídeo. A feira SP-Arte, que acontece no prédio da Bienal de São Paulo, espaço notório de comercialização de arte, em suas últimas edições incluiu a performance e concluiu uma venda, que será integrada em um museu de arte em São Paulo. O SESC (Pompeia), instituição cultural, que procura 
"colocar em debate, trazer para o público, promover de alguma forma com o púbico, um debate aberto sobre o universo plural da produção artística recente" (FRAZÃO, 2016, p. 3) foi responsável pela exposição “Terra Comunal” com a trajetória da notável performer Marina Abramović, na qual muitos registros estiveram presentes, os documentos, objetos fotos e vídeos expostos eram da artista e ao final da mostra retornaram ao seu acervo pessoal. O SESC não possui, portanto, acervo de performance. 
Figura 44 - Mapa com as instituições pesquisas e/ou visitadas por darem acesso a performances, 2016-2018

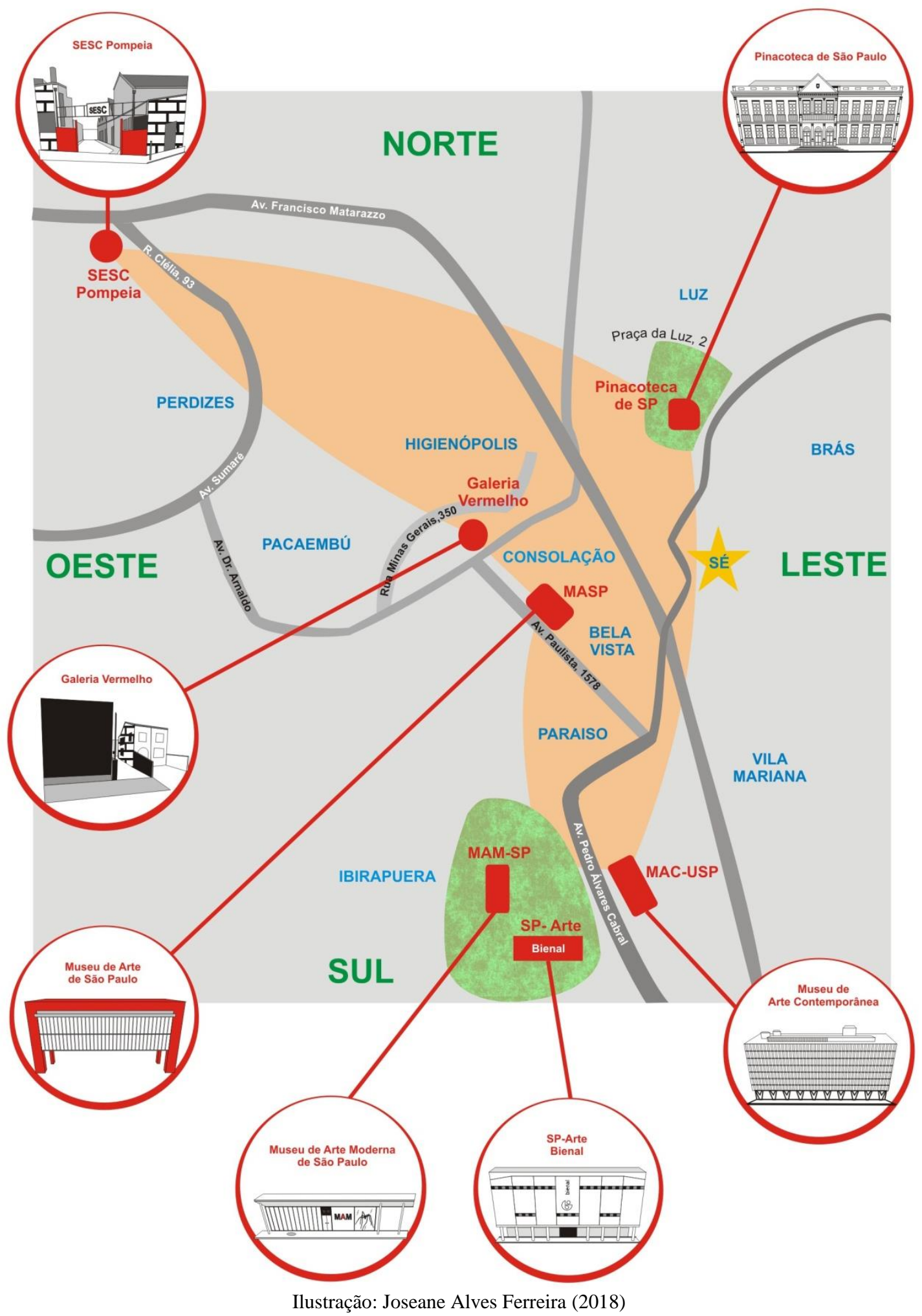

Concluindo, o ato de colecionar objetos sempre esteve presente, desde muito cedo, no âmago das sociedades, todavia os homens adquiriram o hábito de colecionar objetos, e as ações, encenações estiveram no patamar do imaterial, do efêmero. Platão, com o mito da caverna, nos faz refletir quando seus personagens presos a uma caverna, 
tendo ao alcance de seus olhos apenas sombras, criaram uma realidade distorcida, quando um deles consegue alcançar a luz, e ver a realidade colorida e iluminada volta e relata o que viu e sentiu, mas os que ainda estavam acorrentados, na caverna hermética, passam a considerá-lo um louco. Quem sabe os colecionadores, curadores e artistas sejam o personagem que encontrou a luz e estejam ansiosos em dividir com a humanidade, a amplitude que a arte pode oferecer ao mundo, se nos libertarmos das correntes do desconhecimento. A performance pode ser um dos caminhos para se encontrar uma luz, mesmo que só deixem resíduos. Afinal, os mitos sempre dialogaram com a realidade.

Uma coisa que se revela nos mitos é que, no fundo do abismo, desponta a voz da salvação. O momento crucial é aquele em que a verdadeira mensagem de transformação está prestes a surgir. No momento mais sombrio surge a luz (CAMPBELL, 2012, p. 39). 


\section{REFERÊNCIAS BIBLIOGRÁFICAS}

ABRAMOVIĆ, Marina. Performance, Pedagogy, and (Re)presentation: interview. Entrevistadores: Chris Thompson e Katarina Weslien, 2006. Disponível em:

$<$ https://translate.google.com.br/translate?hl=pt-

BR\&sl=en\&u=https://muse.jhu.edu/article/191678\&prev=search>. Acesso em: 18 mai. 2017.

A CIDADE DO HÍMEN NU. Revista O Cruzeiro, Nov, 1956. Disponível em $<$ http://acidadedohomemnu.blogspot.com.br/2010/04/flavio-de-carvalho.html>. Acesso em: 09 out. 2017.

ALBERTIM, Bruno. Cuquinha: um vendedor de gestos. JC on line, 24 abr 2016. Disponível em: <http://jconline.ne10.uol.com.br/canal/cultura/artesplasticas/noticia/2016/04/25/cuquinha-um-vendedor-de-gestos-232709.php>. Acesso em: 15 mai. 2018.

ALVES, Cauê. Cauê Alves: entrevista [6 mai. 2016]. Entrevistadora: Joseane A. Ferreira. São Paulo: Faculdade Belas Artes, 2016. Vídeo. Entrevista concedida para a pesquisa de dissertação de Mestrado do PGEHA-USP.

ARCHER, M. Arte Contemporânea: uma história concisa, São Paulo: Martins Fontes, 2013.

ARGAN, Giulio Carlo. Arte moderna. São Paulo: Companhia das Letras, 2013.

BARDIN, Laurence. Análise de Conteúdo. São Paulo: Edições 70, 2011.

BELLONI, Giuseppe. Artistas vão muito além da tela. Performance Esculturas Vivas de Piero Manzoni, de 1961. Exposição O corpo expandido. Galeria Jaqueline Martins. Época, São Paulo, 27 ago. 2013. Diponível em: <http://epoca.globo.com/regional/sp/cultura/noticia/2013/08/artistas-vao-muito-balemda-telab.html>. Acesso em: 1 jan. 2018.

BENJAMIN, Walter. A obra de arte na era de sua reprodutibilidade técnica. Porto Alegre: L\&PM Editores, 2014.

BENHAMOU, Françoise. A Economia da Cultura. Paris: Editions La Découverte; Cotia, SP: Brasil Ateliê Editorial, 2007.

BEZERRA, Eudes. Kabuki: o teatro popular japonês. Museu de Imagens, s.d. Disponível em: <http://www.museudeimagens.com.br/kabuki-teatro-japones/>. Acesso em: 9 mai. 2017.

BOLAÑO, César et al. Economia da arte e da cultura. Porto Alegre: Itaú Cultural, 2010.

CAMPBELL, Joseph. O poder do mito. São Paulo: Palas Athenas Ed. 2012.

CAUQUELIN, Anne. Arte Contemporânea: uma introdução. São Paulo: Martins Fontes, 2005. 
CHANDON. Chandon Lovers. s.d. Disponível em: <http://www.chandon.com.br/achandon/grupo-lvmh/>. Acesso em: 13 jan. 2018.

CHAIMOVICH, Felipe. Felipe Chaimovich: entrevista [17 mai. 2016]. Entrevistadora: Joseane A. Ferreira. São Paulo: MAM, 2016. E-mail. Entrevista concedida para a pesquisa de dissertação de Mestrado do PGEHA-USP.

CLARO, Camila; MARETTI, Eduardo. O teatro dialético de Brecht. Revista Forum, 21 out. 2011. Disponível em: <http://www.revistaforum.com.br/2011/10/21/o-teatrodialetico-de-brecht/>. Acesso em: 9 mai. 2017.

COELHO, Valeria. Yves Klein. Hardecor, s.d. Disponível em: <http://hardecor.com.br/yves-klein/>. Acesso em: 19 mai. 2017.

COHEN, Renato. Performance como linguagem: criação de um tempo-espaço de experimentação. São Paulo: Perspectiva, 2013.

COTE, Larissa; GAIONE, Vivian. Tunga: Galeria True Rouge, 2017. Disponível em: <https://gvcult.blogosfera.uol.com.br/2017/06/29/tunga-galeria-true-rouge/>. Acesso em: 15 out. 2017

COUTINHO, Liliana. Mostra de performance arte. In: GALLON, Marcos (Org.). Dar direito de cidadania a performance. São Paulo: Galeria Vermelho, 2015.

DANÇA MODERNA. A musa moderna Martha Graham: um pouco da sua história. 24 jun. 2014. Disponível em: <http://dancamoderna.com.br/2014/musa-moderna-marthagraham-um-pouco-da-sua-historia/>. Acesso em: 9 mai. 2017.

D'ARAUjO, Maria Celina. O AI-5. Centro de Pesquisa e Documentação de História Contemporânea do Brasil. s.d. Disponível em:

<http://cpdoc.fgv.br/producao/dossies/FatosImagens/AI5>. Acesso em: 13 jan. 2018.

DEL, Felipe. Ponto: Teatro da Crueldade. SP Escola de Teatro, 18 out. 2011. Disponível em: <http://www.spescoladeteatro.org.br/noticias/ver.php?id=1432>. Acesso em: 9 mai. 2017.

DUODELUXO. Flavio de Carvalho, New Look, passeata por São Paulo, 1956.

Disponível em: <https://duodeluxo.wordpress.com/2010/11/15/flavio-de-carvalhodesveste-a-moda/>. Acesso em: 09 out. 2017.

ENCICLOPÉDIA ITAÚ CULTURAL. Fluxus. Artes visuais. São Paulo: Itaú Cultural, 2017. Disponível em: <http://enciclopedia.itaucultural.org.br/termo3652/fluxus>. Acesso em: 01 jun. 2017.

ESCRITÓRIO DE ARTE. Exposição Flavio de Carvalho: A cidade do homem nu, s.d. Disponível: <https://www.escritoriodearte.com/blog/exposicoes/exposicao-flavio-decarvalho-a-cidade-do-homem-nu/>. Acesso em: 18 out. 2017.

FLICKR. Artexplorer. s.d. Disponível em: <https://www.flickr.com/photos/artexplorer/3038248661>. Acesso em: 15 mai. 2018. 
FLICKR. Artexplorer. Disponível em:

<http://www.flickriver.com/photos/artexplorer/3039011812/>. Acesso em: 15 mai 2018.

FONSECA, Victor Pinto da. O Vazio Apocalíptico. Arte Capital, 5 nov. 2016. Disponível em: <http://www.artecapital.net/estado-da-arte-68-victor-pinto-da-fonseca-ovazio-apocaliptico>. Acesso em: 19 mai. 2017.

FRAZÃO, Alcimar. Alcimar Frazão: entrevista [19 mai. 2016]. Entrevistadora: Joseane A. Ferreira. São Paulo: SESC Pompeia, 2016. Vídeo. Entrevista concedida para a pesquisa de dissertação de Mestrado do PGEHA-USP.

GAGNIER, Richard. Media art: history, installation and conservation. s.d. Disponível em: <http://www.virtualmuseum.ca/sgc-cms/expositions-exhibitions/arts_mediatiquesmedia_arts/art_mediatique-media_art-eng.php\&prev=search>. Acesso em: 28 fev. 2018.

GALERIA NARA ROESLER. Exposição Paulo Bruscky. São Paulo, 2017. Disponível em: <https://nararoesler.art/exhibitions/108/>. Acesso em: 1 jan. 2018.

GALLON, Marcos. Marcos Gallon: entrevista [4 mai. 2016]. Entrevistadora: Joseane A. Ferreira. São Paulo: Galeria Vermelho, 2016. Vídeo. Entrevista concedida para a pesquisa de dissertação de Mestrado do PGEHA-USP.

GALLON, Marcos. Marcos Gallon: A escritura [18 out. 2017]. Entrevistadora: Joseane A. Ferreira. São Paulo, 2017. E-mail. Entrevista concedida para a pesquisa de dissertação de Mestrado do PGEHA-USP.

GALLON, Marcos. Mostra de performance arte. São Paulo: Galeria Vermelho, 2015. Catálogo.

GETTY IMAGES. Allan Kaprow Artist Pictures and Images, s.d. Disponível em: $<$ http://www.gettyimages.com/photos/allan-kaprow--artist?excludenudity $=$ true $\&$ mediatype $=$ photography $\&$ phrase $=$ allan $\% 20 \mathrm{kaprow} \% 20$ \%20artist\&sort=mostpopular>. Acesso em: 19 mai. 2017.

GLUSBERG, Jorge. A arte da performance. São Paulo: Perspectiva, 2013.

GOLDBERG, Roselee. A arte da performance do futurismo ao presente. São Paulo: Martins Fontes, 2015.

GULLAR. Ferreira. Argumentação contra a morte da arte. 4. Rio de Janeiro: Revan, 1993.

HANDA, Francisco. Kabuki: uma forma de teatro popular estilizado. Cultura Japonesa.com.br. s.d. Disponível em:

<http://www.culturajaponesa.com.br/?page_id=461>. Acesso em: 9 mai. 2017.

INHOTIM. Deborah Gomes. Facebook, s.d. Disponível:

<https://www.facebook.com/dafafich/posts/605430926283735>. Acesso em: 15 out. 2017.

INHOTIM. Histórico. s.d. Disponível em:

<http://www.inhotim.org.br/inhotim/sobre/historico>. Acesso em: 15 mai. 2018. 
KIMURA, Karin. O que é teatro Nô? Made in Japan, 20 mai. 2015. Disponível em: <http://madeinjapan.com.br/2015/05/20/o-teatro-noh/>. Acesso em: 9 mai. 2017.

KOPPELMAN, Dorothy. Jackson Pollock - and True \& False Ambition: The Urgent Difference. Terrain Gallery, s.d. Disponível em: <http://terraingallery.org/artcriticism/jackson-pollock-and-true-false-ambition-the-urgent-difference/>. Acesso em: 19 mai. 2017.

LEITE, Edson. Turismo Cultural e Patrimônio Imaterial no Brasil. São Paulo: Intercom, 2011.

LIMA, Laura. Marra, 1996. A espiral e a praça, Bonniers Konsthall, Estocolmo, 2011. Disponível em: <http://www.tanyabonakdargallery.com/artists/lauralima/emodal/selected-works_2>. Acesso em: 1 jan. 2018.

MARTİ, Silas. Rio refaz performance de Lygia Pape. 21 de jun. 2010. Folha de S.Paulo Ilustrada. Disponível em: <http://www1.folha.uol.com.br/fsp/ilustrad/fq2106201014.htm>. Acesso em: 12 jan. 2018.

MARTÍNEZ, Pamela Muñoz. "Fluxus": La revolución del Arte. Cultura Colectiva, 4 abr. 2014._Disponível em: <http://culturacolectiva.com/fluxus-la-revolucion-del-arte/>. Acesso em: 19 mai. 2017.

MEDEIROS, Bia. Gutai Bitjutsu Kyokai. Paris, 22 jun. 1999. Disponível em: <http://www.corpos.org/papers/gutaibitjutsu.html>. Acesso em: 9 mai. 2017.

MORAES, Juliana. Juliana Moraes: entrevista [24 mai. 2016]. Entrevistadora: Joseane A. Ferreira. São Paulo: Faculdade Belas Artes, 2016. Vídeo. Entrevista concedida para a pesquisa de dissertação de Mestrado do PGEHA-USP.

MORISAWA, Mariane. Marina Abramovic: Quanto pior sua infância, melhor sua arte. Marie Claire, São Paulo, 24 out. 2012. Disponível em: $<$ http://revistamarieclaire.globo.com/Revista/Common/0,EMI320194-17735-1,00MARINA+ABRAMOVIC+QUANTO+PIOR+SUA+INFANCIA+MELHOR+SUA+AR TE.html>. Acesso em: 13 abr. 2017.

MUSEO NACIONAL CENTRO DE ARTE REINA SOFIA. Divisor. A Lygia Pape performance. 24 mai. 2011. Disponível em:

<http://www.museoreinasofia.es/en/actividades/divisor-lygia-pape-performance>. Acesso em 13 jan. 2018.

MEDEIROS, Raquel. Costurando ideias/ A cultura da moda alinhavada com a história, sustentabilidade e comportamento, Nas Entre Linhas, 15 out. 2012. Disponível em: $<$ http://www.nasentrelinhas.com.br/noticias/costurando-ideias/349/o-new-look-de-flaviode-carvalho/>. Acesso em: 18 out. 2017.

OLIVA, Fernanda. Mostra de performance arte. In: GALLON, Marcos (Org.). Uma nova performance para um novo público. São Paulo: Galeria Vermelho, 2015. 
OLIVEIRA, Thais. Apesar de ser uma arte crescente, mercado de performances ainda é restrito. 1 mai 2016. Disponível em: <http://hojeemdia.com.br/almanaque/apesar-de-seruma-arte-crescente-mercado-de-performances-ainda-\%C3\%A9-restrito-1.380884>. Acesso em 6 jun. 2016.

PASCHOLATI, Aline. Arte, exposição Highlights da SP-Arte 2017. Artrianon, s.d. Disponível em <https://artrianon.com/2017/04/25/highlights-da-sp-arte-2017/>. Acesso em: 15 out. 2017.

PINHO, Diva Benevides. A Arte no Brasil e no Ocidente: do século 21 ao século 16 uma visão transdisciplinar. Santo André: ESETec, 2008.

PISAURO, Valéria. Chris Burden body art e performance. Valiteratura, 22 jan. 2013. Disponível: <http://valiteratura.blogspot.com.br/2012/07/chris-burden-body-art-eperformance.html>. Acesso em: 13 nov. 2017.

POGREBIN, Robin. Once on Fringe, Performance Art Is Embraced. The New York Times, 26 Oct. 2012. Disponível em:

<https://www.nytimes.com/2012/10/28/arts/artsspecial/performance-art-is-increasingly-amainstream-museum-staple.html>. Acesso em: 31 ago. 2017.

RAHE, Nina. Vendem-se performance. Folha de S.Paulo, São Paulo: 2016. Ilustrada.

SCHECHNER, Richard. O que é performance? In: SCHECHNER, Richard. Performance studies: an introduccion. 2. ed. New York, London: Routledge, 2006.

REGIS, Camila. Select. 7 abr 2016. Disponível em: <https://www.select.art.br/quantocusta-uma-performance/>. Acesso em: 15 mai 2018.

REIS, Ana Carla Fonseca. Marketing cultural e financiamento da cultura. São Paulo: Thomson, 2003.

RIVERO, Manuel R. Donde dije digo, digo Diego. El País, 30 Jan. 2016. Disponível em: <http://cultura.elpais.com/cultura/2016/01/27/babelia/1453915199_341191.html>.

Acesso em: 9 mai. 2017.

SANTOS, Diogo Gomes dos. Diogo Gomes dos Santos: entrevista [7 mai. 2016].

Entrevistadora: Joseane A. Ferreira. São Paulo: Associação Centro Cineclubista de São Paulo, 2016. vídeo. Entrevista concedida para a pesquisa de dissertação de Mestrado do PGEHA-USP.

SANTILLAN, Melinda. Rip Chris Burden. 01 Magazine, 12 May 2015. Disponível em: <http://zero1magazine.com/2015/05/65080/>. Acesso em: 7 jan. 2018.

SANTILlAN, Melinda. Chris Burden: Shoot. F Space, Santa Ana, California, 19 Nov. 1971. Disponível em: <http://zero1magazine.com/2015/05/65080/>. Acesso em: 7 jan. 2018.

SCARTEZINI, Bernardo. Viagem pela arte contemporânea na coleção de Sérgio Carvalho. Metrópoles, 25 nov. 2017. Disponível em:

<https://www.metropoles.com/colunas-blogs/plastica/viagem-pela-arte-contemporaneana-colecao-de-sergio-carvalho>. Acesso em: 28 fev. 2018. 
SCHECHNER, Richard. Performance studies: an introduccion. 2. ed. New York, London: Routledge, 2006.

SESC em São Paulo. DNA de DAN | Maikon K | 8 Performances | Terra Comunal Marina Abramovic +MAI, 31 mar. 2015. Disponível em:

<https://www.youtube.com/watch?v=bWf9PQW2EDo>. Acesso em: 12 fev. 2018.

SELLTIZ, Claire et al. Métodos de pesquisa nas relações sociais. Ed. rev. São Paulo: Edusp, 1975.

SIQUEIRA, Cris. Para a galera do rio: grupo empreza no mar! 14/05/2014

Disponível em: <http://www.coxinhanerd.com.br/grupo-empreza-no-mar/>. Acesso em: 28 fev. 2018.

SLEEK. Keren Cytter on Swan Lake, beauty and Yvonne Rainer, 28 mar. 2012.

Disponível em: <http://www.sleek-mag.com/2012/03/28/keren-cytter-on-swan-lakebeauty-and-yvonne-rainer/>. Acesso em: 9 mai. 2017.

SLIDE SHARE. Trabalho sobre Fluxus (Yoko Ono). 21 dez. 2012. Disponível em: <https://pt.slideshare.net/claudiowww/trabalho-sobre-fluxus-yoko-ono>. Acesso em: 1 jan. 2018.

SUPERFICIEDOSENSÍVEL. Grupo Gutaï: relação entre pintura e performance. 5 mar. 2013. Disponível em <https://superficiedosensivel.wordpress.com/2013/03/05/grupogutai/>. Acesso em: 19 mai. 2017.

TATE, Conservação - mídia baseada no tempo. s.d. Disponível em:

$<$ https://translate.google.com.br/translate?hl=pt-

PT\&sl=en\&u=http://www.tate.org.uk/about/our-work/conservation/time-basedmedia\&prev=search>. Acesso em: 31/8/2017.

TEIXEIRA, Luís Fabiano. Os parangolés de Hélio Oiticica. 25 mai. 2010. Disponível em: $<$ http://www.culture-se.com.br/noticias/84/os-parangoles-de-helio-oiticica>. Acesso em: 12 fev. 2018.

BABAANTROPOFAGICA.blogspot.com.br. Baba antropofágica. 13 fev. 2009. Disponível em: <http://babaantropofagica.blogspot.com.br/>. Acesso em: 07 jan. 2018.

TOLENTINO, Cristina. Jerzy Grotowski - e o ator-performer. O Ator para Grotowski. Caleidoscopio.Art, 2005. Disponível em:

<http://www.caleidoscopio.art.br/cultural/teatro/teatro-contemporaneo/jerzy-grotowskiintroducao.html>. Acesso em: 9 mai. 2017.

TRIGO, Luciano. A Grande Feira: uma reação ao vale-tudo na arte contemporânea. Rio de Janeiro: Civilização Brasileira, 2009.

URIBE, Begoña. Museu Nacional Honestino Guimarães, pelas lentes de Gonzalo Viramonte. 22 abr. 2016. Disponível em: $<$ https://www.archdaily.com.br/br/786095/museu-nacional-honestino-guimaraes-pelaslentes-de-gonzalo-viramonte>. Acesso em: 28 fev. 2018. 
VENTURA, Zuenir. 1968: O ano que não terminou. Rio de Janeiro: Nova Fronteira, 1988.

VISUAL-ARTV. Performance O Nome, 27 nov. 2013. Disponível em: <http://visualartv.blogspot.com.br/2013/11/pinacoteca-o-nome-de-mauricio-ianes.html >. Acesso em: 5 jun. 2016. 


\section{APÊNDICES}




\section{APÊNDICE A - \\ ENTREVISTADOS (breve currículo)}

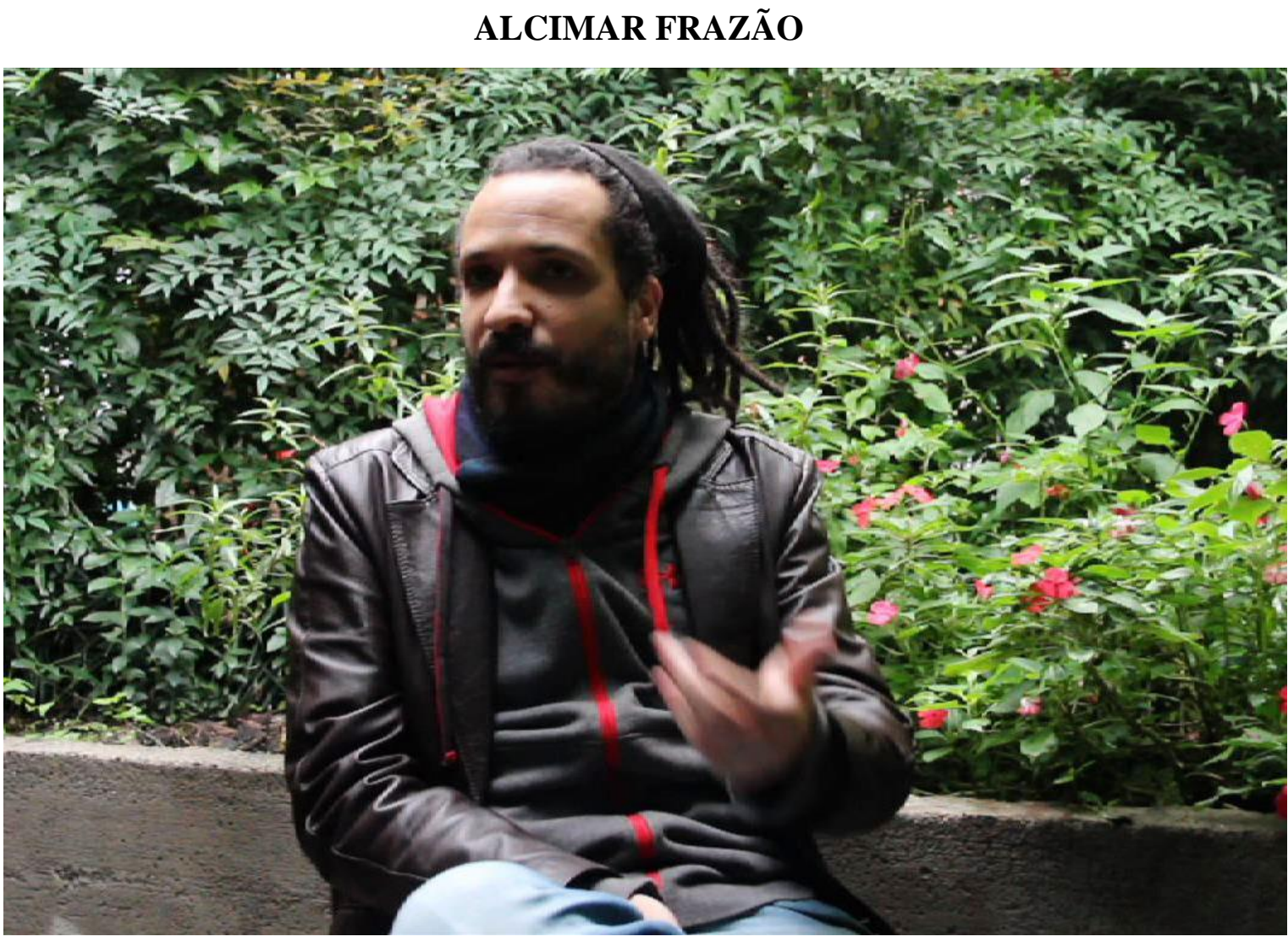

Foto: Joseane Alves Ferreira

Quadrinista e ilustrador. Atualmente é Supervisor do Núcleo de Artes Visuais no Sesc/ Pompeia. É autor da novela gráfica O Diabo \& Eu (2016) publicada no Brasil, Espanha e Portugal. Também é autor de HQ Me \& Devil (2016), sobre o músico de jazz norte-americano Robert Johnson. Fez parte do coletivo de quadrinistas Bimbo Groovy e do coletivo $O$ Соntínuo, onde publicou 7 edições, 2 álbuns especiais e realizou a exposição, junto ao SESC São Paulo, Cazuza por ele mesmo..., com uma HQ em homenagem ao músico. Em 2013 foi curador, com Paulo Ramos, da exposição HQBR21 - O Quadrinho Brasileiro do Novo Século, o primeiro panorama crítico da nova geração de autores brasileiros.

Foi responsável pela montagem no SESC Pompeia da exposição dedicada à obra da performer Marina Abramović - Terra Comunal, em 2015. 


\section{CAUÊ ALVES}

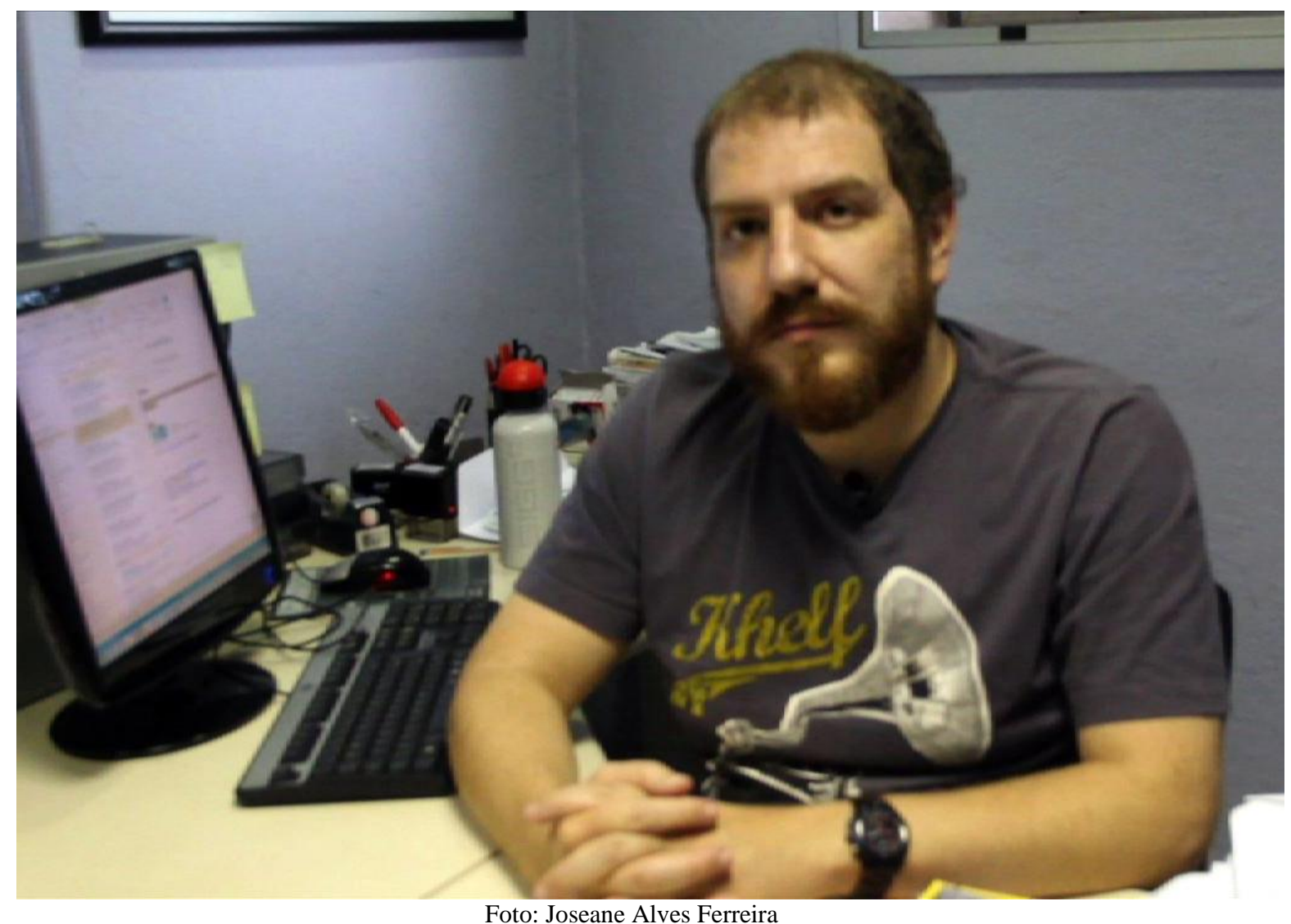

É doutor em Filosofia, professor do Departamento de Arte da Faculdade de Filosofia, Comunicação, Letras e Artes da PUC-SP e do Centro Universitário Belas Artes de São Paulo. Atualmente é curador geral do Museu Brasileiro de Escultura - MuBE. Foi um dos curadores do $32^{\circ}$ Panorama da Arte Brasileira do Museu de Arte Moderna de São Paulo (2011) e curador adjunto da $8^{a}$ Bienal do Mercosul (2011). Foi membro do Conselho Consultivo de Artes do MAM-SP (2005-2007) e curador do Clube de Gravura do MAM-SP (2006-2016). É autor do livro Mira Schendel: avesso do avesso e da mostra homônima (Bei Editora/ IAC, 2010).

Foi curador assistente do Pavilhão Brasileiro da 56 ${ }^{\mathrm{a}}$ Bienal de Veneza (2015). Foi cocurador da mostra Sergio Camargo: Luz e Matéria, no Itaú Cultural e Fundação Iberê Camargo (2015-2016).

Em 2016 foi curador em conjunto com a professora de performance Juliana Moraes, ambos do Centro Universitário Belas Artes de São Paulo, com trabalhos de alunos que foram apresentados no setor dedicado à performance na SP-Arte 2016. 


\section{FERNANDA PITTA}

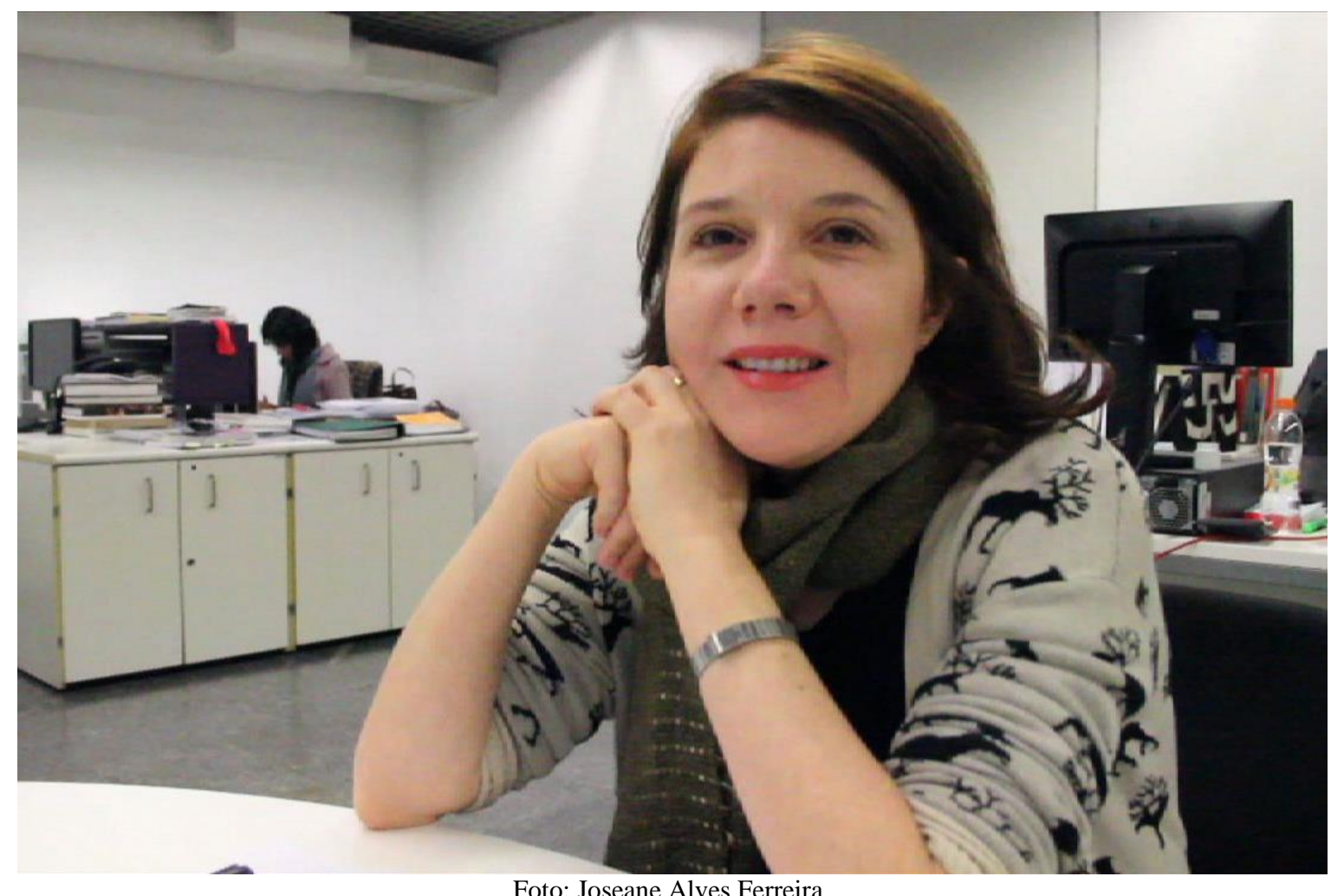

Foto: Joseane Alves Ferreira

Historiadora da arte, pesquisadora e curadora da Pinacoteca do Estado de São Paulo e professora de História da Arte na Escola da Cidade, Faculdade de Arquitetura e Urbanismo. É bacharel e mestre em História pela Universidade Estadual de Campinas. Doutora em Artes Visuais pela Escola de Comunicação e Artes da Universidade de São Paulo. É pesquisadora da arte no Brasil, com ênfase na produção dos séculos XIX e XX. É membro do Grupo de Estudos Arte \& Fotografia, da ECA-USP. Foi membro do corpo editorial da Revista Número.

Foi colaboradora do projeto editorial Arte no Brasil: Textos críticos do século $X X$, coordenado pelo Museum of Fine Arts Houston (EUA). Realizou a curadoria de Eleonore Koch: Mundo ordenado (2009) e Junior Suci: Necessidade do Objeto (2011), no Centro Universitário Maria Antonia. É curadora, com Valéria Piccoli, da exposição Coleções em Diálogo: Museu Mariano Procópio e Pinacoteca de São Paulo (2014-2015). É autora de textos sobre historiografia da arte e arte no Brasil, publicados em livros, periódicos especializados e catálogos de exposição. 


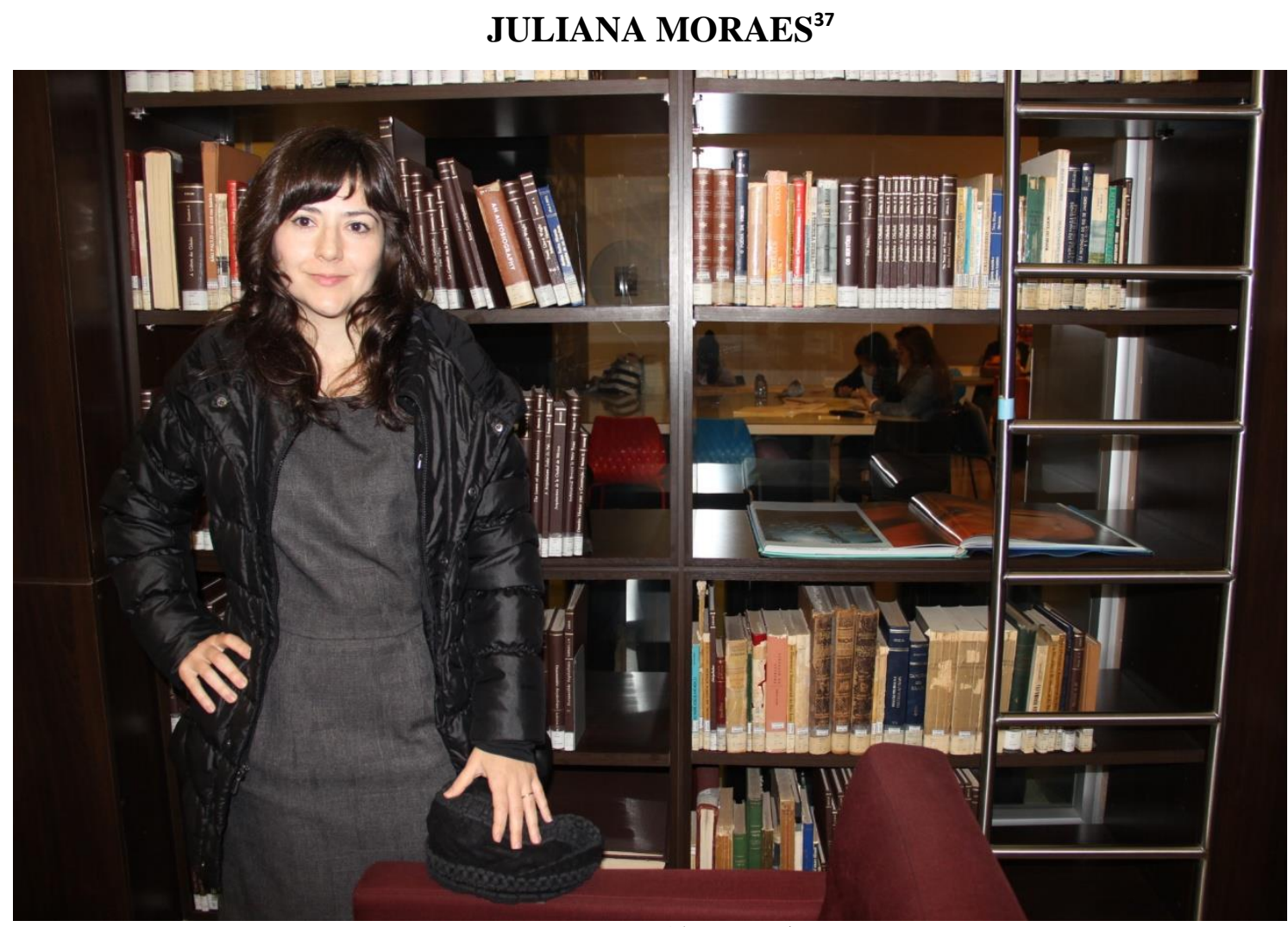

Foto: Joseane Alves Ferreira

Bailarina, coreógrafa e professora. Doutora em Artes e Bacharel em Dança pela Unicamp. Possui especialização e mestrado (com distinção) pelo Laban Centre for Movement and Dance - City University, Londres, revalidado pela ECA-USP. Desde 2005 é professora de performance no Bacharelado em Artes Visuais do Centro Universitário Belas Artes de São Paulo. Desde 2010, trabalha nos meses de janeiro como professora convidada da Accademia Teatro Dimitri, em Verscio, na Suíça italiana. Conhece em profundidade o Sistema Laban. Estuda balé clássico, com enfoque somático, com a professora Zélia Monteiro, em São Paulo, desde 2002.

Ganhou prêmios importantes como o Prêmio da Associação Paulista de Críticos de Arte (APCA), a Bolsa Vitae de Artes, o Rumos Itaú de Obras Coreográficas e três edições do Cultura Inglesa Festival. Fundou a Companhia Perdida em 2008 e a dirigiu até sua dissolução em 2014. Em 2013, lançou o livro Dança, frente e verso, pela editora Versos. Em 2015, retomou a carreira solo com a peça Desmonte, e, em 2016, estreou o novo solo Eu Elas. Frequentemente se engaja em projetos colaborativos com músicos, atores e performers, criando site specifics, instalações coreográficas e improvisações cênicas. Cursa formação em psicanálise pelo Instituto Sedes Sapientiae/SP.

\footnotetext{
${ }^{37}$ Currículo enviado pela entrevistada.
} 


\section{LAURA LIMA}

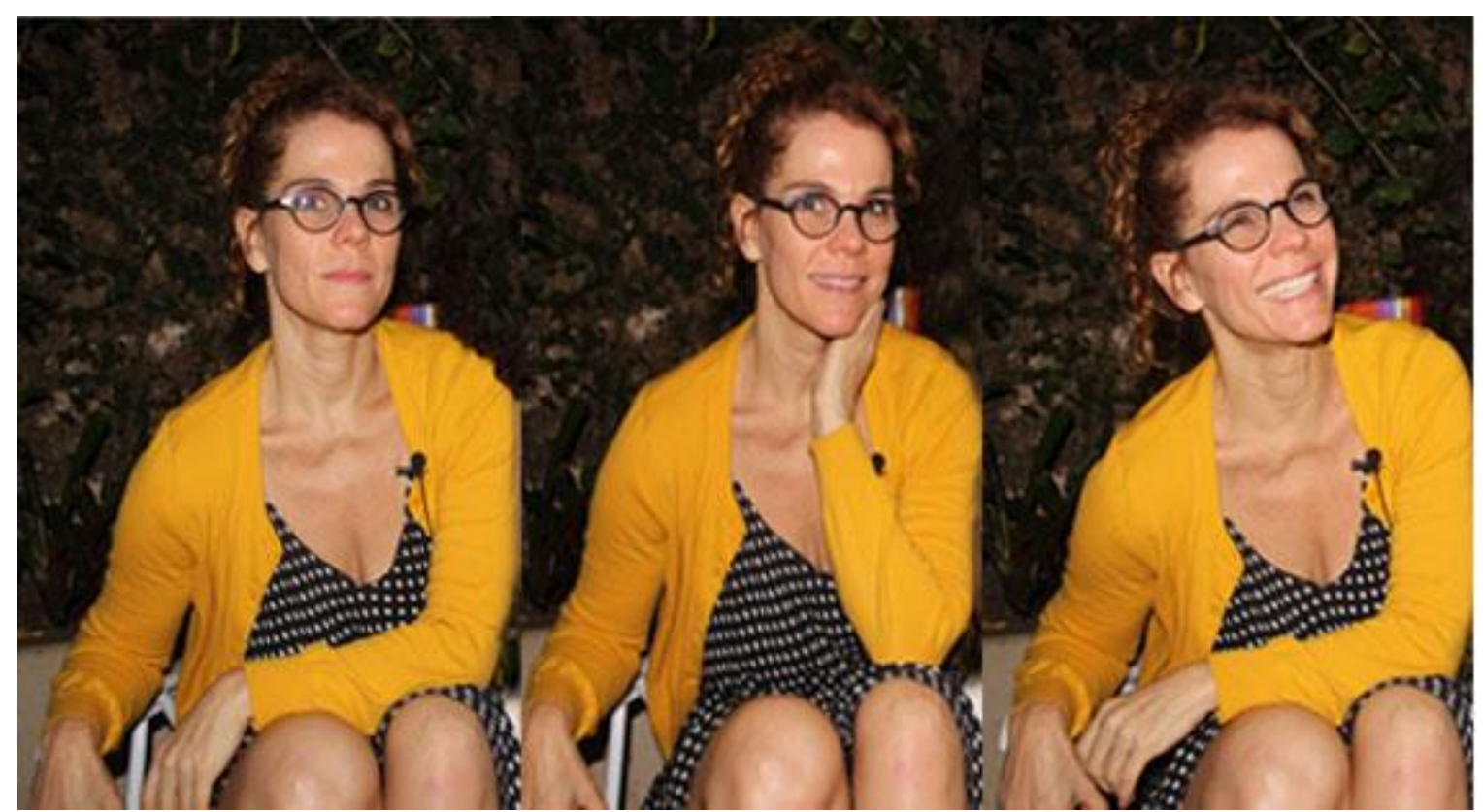

Foto: Diogo Gomes dos Santos

Natural de Governador Valadares/MG e radicada no Rio de Janeiro, é formada em Filosofia pela Universidade Estadual do Rio de Janeiro, e frequentou a Escola de Artes Visuais do Parque Lage no Rio de Janeiro. Em 2003 fundou, em parceria com os artistas Ernesto Neto e Márcio Botner, a galeria de arte "A Gentil Carioca". Uma característica marcante em seus trabalhos são modelos vivos, animais e vegetais como suporte de suas criações.

Participou de exposições nacionais e internacionais, coletivas e individuais, entre elas, a $24^{\mathrm{a}}$ e $27^{\mathrm{a}}$ Bienal de São Paulo; $2^{\mathrm{a}}$ e $3^{\mathrm{a}}$ Bienal do Mercosul, Porto Alegre/RS; Instâncias To Age, Chapter Art Centre, Cardiff/País de Gales; A Little Bit of History Repeated, Kunst Werke, Berlim/Alemanha; Alegoria Barroca na Arte Contemporânea, Centro Cultural Banco do Brasil, Rio de Janeiro/RJ; La Centrale, Montreal/Canadá; Casa França Brasil, no Rio de Janeiro/RJ, entre outras. Artista-Curadora Adjunta da $7^{a}$ Bienal do Mercosul Grito e Escuta do Pavilhão Absurdo, dentre outros.

Acredita que o pensamento é vivo, e não vê seu trabalho como performance, no sentido de performance historicamente, mas atua com corpos sempre são modificados em carne, objetos, para ela um corpo pode ser moldado como o barro.

Foi a primeira artista brasileira a ter obras na categoria "Performance" por um Museu Brasileiro, o Museu de Arte Moderna de São Paulo [MAM-SP], e abriu espaços para outros artistas dessa natureza adentrarem em acervos de museus, seus trabalhos estão presentes em diversas coleções nacionais e internacionais. 


\section{LORIVAL CUQUINHA}

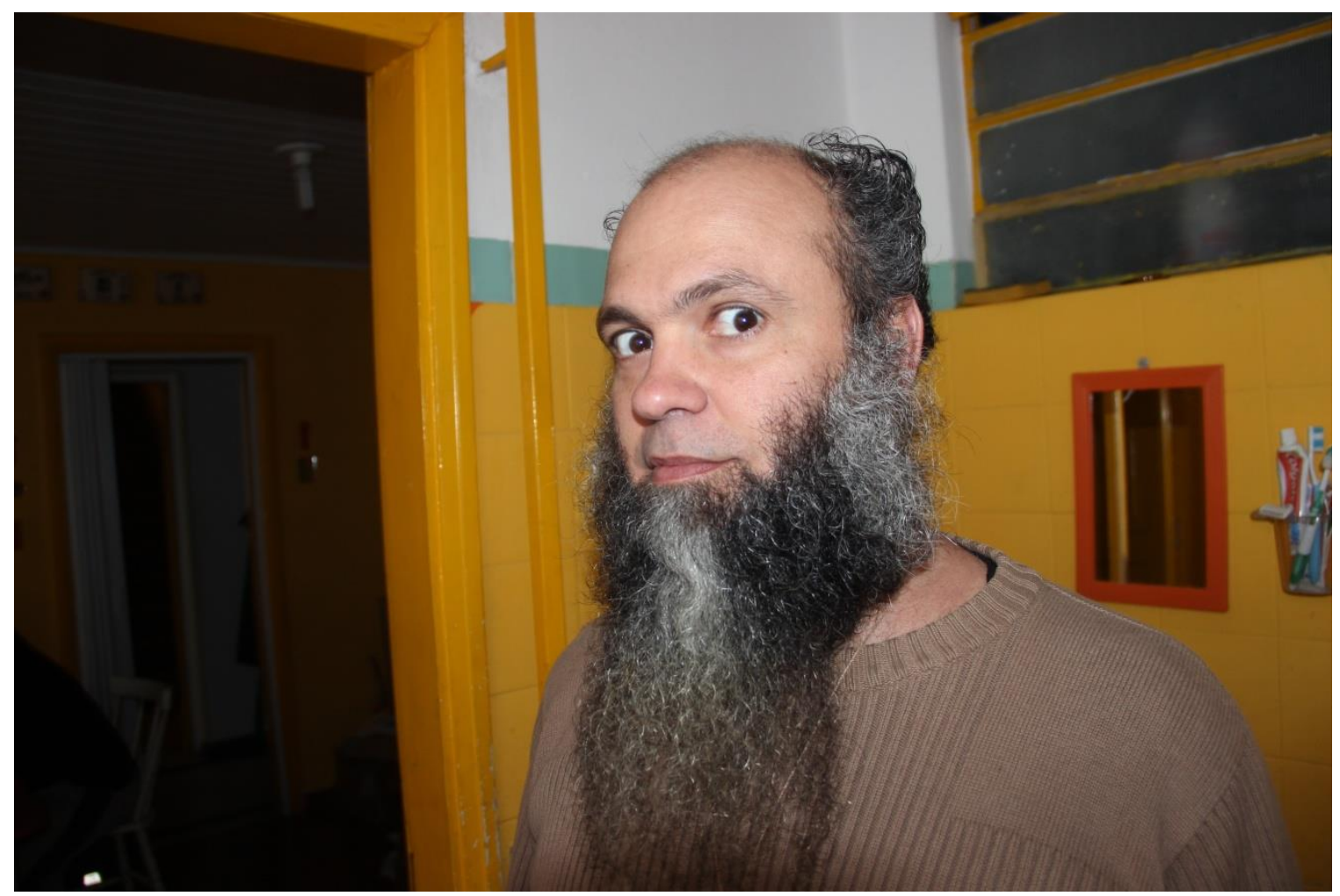

Foto: Joseane Alves Ferreira

Natural de Recife/Brasil, Cuquinha, como é conhecido, é artista visual e trabalha com várias mídias. Inicia nas artes visuais, com um coletivo de artistas, Molusco Lama, nos idos de 1996 ou 1997, com muitas ações e performances. Sempre com trabalhos no campo político, parte de impressões estritas e pessoais. Não concluíu nenhum curso acadêmico, mas cursou Engenharia Química, Filosofia, Direito e História. Atua nas artes plásticas, fotografia, cinema e vídeo e intervenção urbana. Participou de exposições nacionais e internacionais, marcadamente por características de interatividade com o público e com o meio urbano. Reflete pensamentos sobre a liberdade do indivíduo e o controle que a sociedade e a cultura exercem sobre este; bem como sobre a liberdade da arte, e o controle exercido sobre ela pelas instituições, e o estatuto sobre o que é "obra de arte", verificando os limites das instituições, criticando-as, mas num contínuo processo de negociação e adesão.

Recebeu vários prêmios, dentre eles: Prêmio Brasil contemporâneo mostra de artistas brasileiros no exterior, da Fundação Bienal de São Paulo, 2010; Prêmio Registros do Canal Contemporâneo pelo trabalho Parangolé, Novembro 2010; Bolsa residência em Londres do programa Artist Links do British Council, com o trabalho Topografia Suada de Londres, Julho a Dezembro de 2009. 
MARCOS GALLON ${ }^{38}$

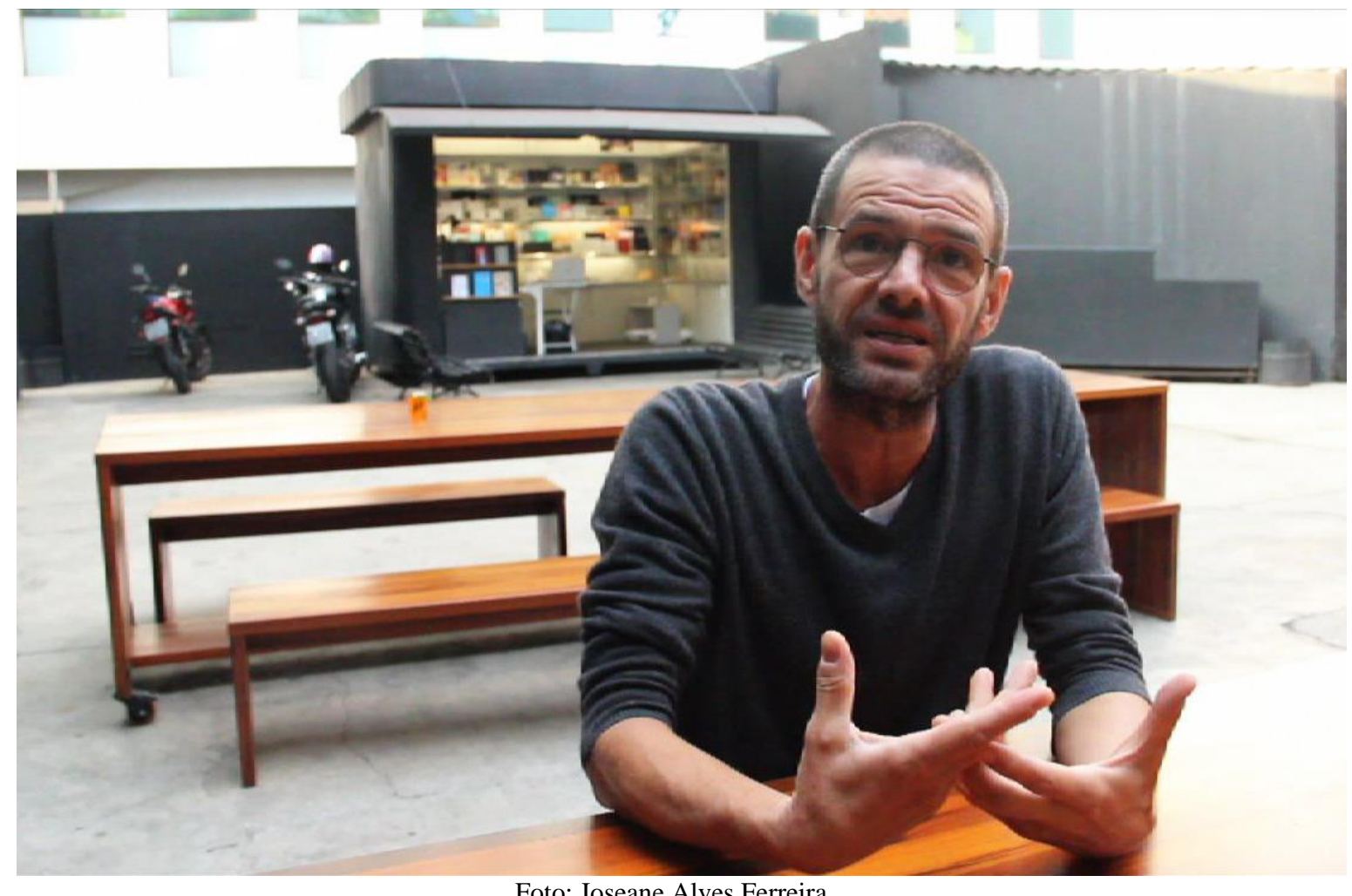

Foto: Joseane Alves Ferreira

Possui graduação em Filosofia pela Pontifícia Universidade Católica de São Paulo (PUC-SP). Como bailarino e coreógrafo trabalhou em várias companhias de dança em São Paulo. De 1993 a 1996 assumiu o cargo de Administração da Cia. Terceira Dança em São Paulo. Viveu quatro anos em Berlim (1997-2001), onde ampliou sua pesquisa no campo da dança contemporânea, tendo desenvolvido vários trabalhos junto a coreógrafos da cena local. Nos anos de 2003 e 2004 criou o projeto Corpo de Baile, coletivo composto por bailarinos, performers, designers, atores e artistas visuais. Atualmente é diretor artístico da VERBO - Mostra de Performance Arte, plataforma anual de performance arte criada em parceria com a Galeria Vermelho (São Paulo), em 2005.

É coautor de Das, um olhar contemporâneo sobre um trabalho da Cia. Terceira Dança (publicado pela Annablume, em 1995), e organizador de Verbo - mostra de performance arte.

\footnotetext{
${ }^{38}$ Currículo enviado pelo entrevistado.
} 


\section{MAURÍCIO IANÊS}

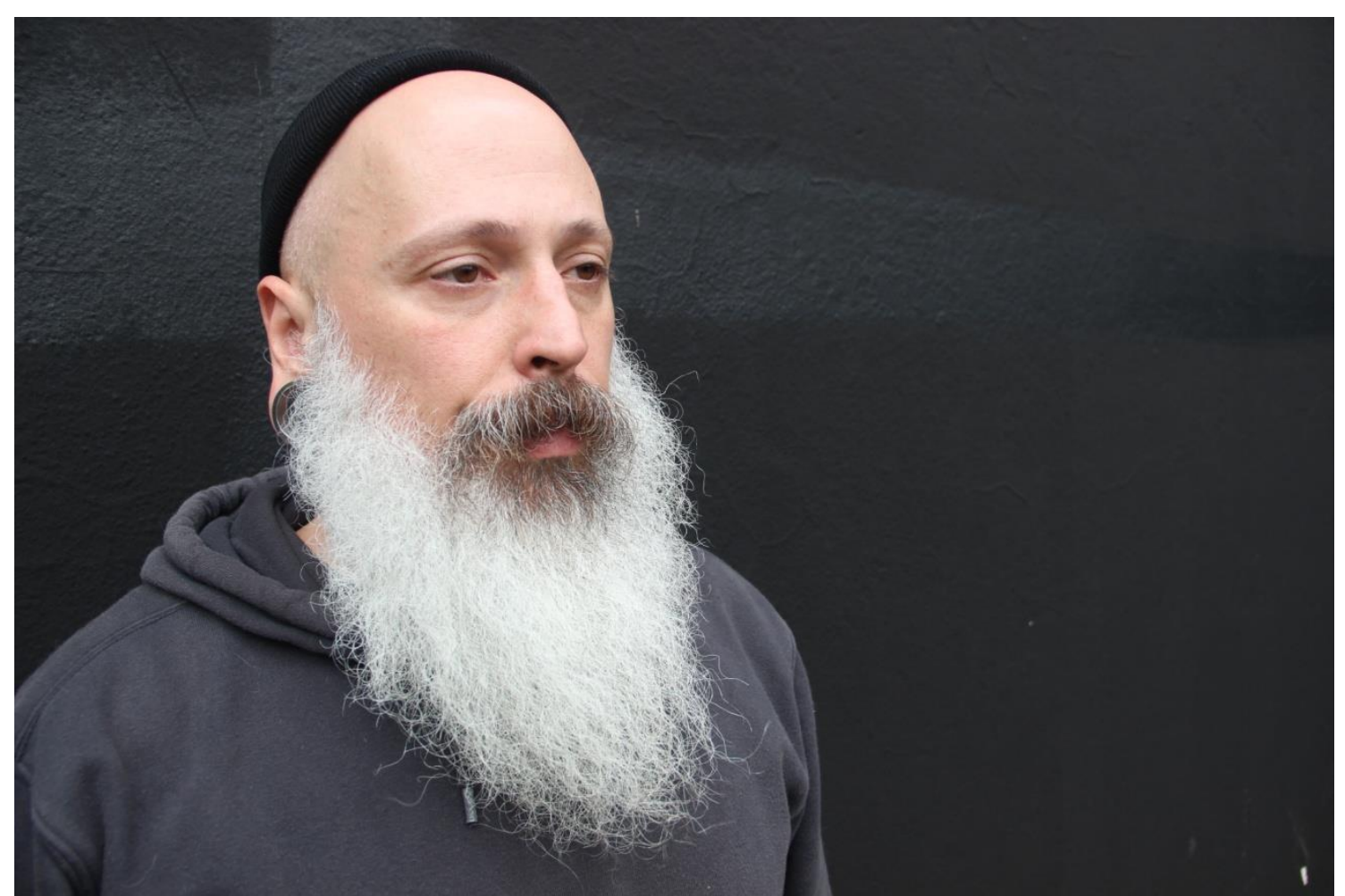

Foto: Joseane Alves Ferreira

É formado pela Faculdade de Artes Plásticas da Fundação Armando Álvares Penteado, em São Paulo. Seu trabalho questiona as linguagens verbal e artística, suas possibilidades expressivas e limites, suas funções políticas e sociais, muitas vezes propondo a participação do público em suas ações para criar situações de troca onde a linguagem e os seus desdobramentos sociais entram em jogo. Ianês busca referências e influências em filosofia, poesia, crítica social, literatura e música.

Ações e performances que buscam questionar a relação entre espectador e artista, tirando o espectador do papel de observador passivo e transformando-o em parte importante da criação da obra são características do trabalho de Ianês.

Já participou de importantes exposições nacionais e internacionais, como as $28^{\mathrm{a}} \mathrm{e}$ a 29a Bienais Internacionais de São Paulo, SP; Des Choses en Moins, Des Choses en Plus, Palais de Tokyo, Paris, França; Avante Brasil, KIT Kunst im Tunnel, Düsseldorf, Alemanha; Il Va se Passer Quelque Chose, Maison de L'Amérique Latine, Paris, França; Chambres Sourdes, Parc Culturel de Rentilly, França.

A performance $O$ nome, de 2011, é parte integrante do acervo da Pinacoteca do Estado de São Paulo. 


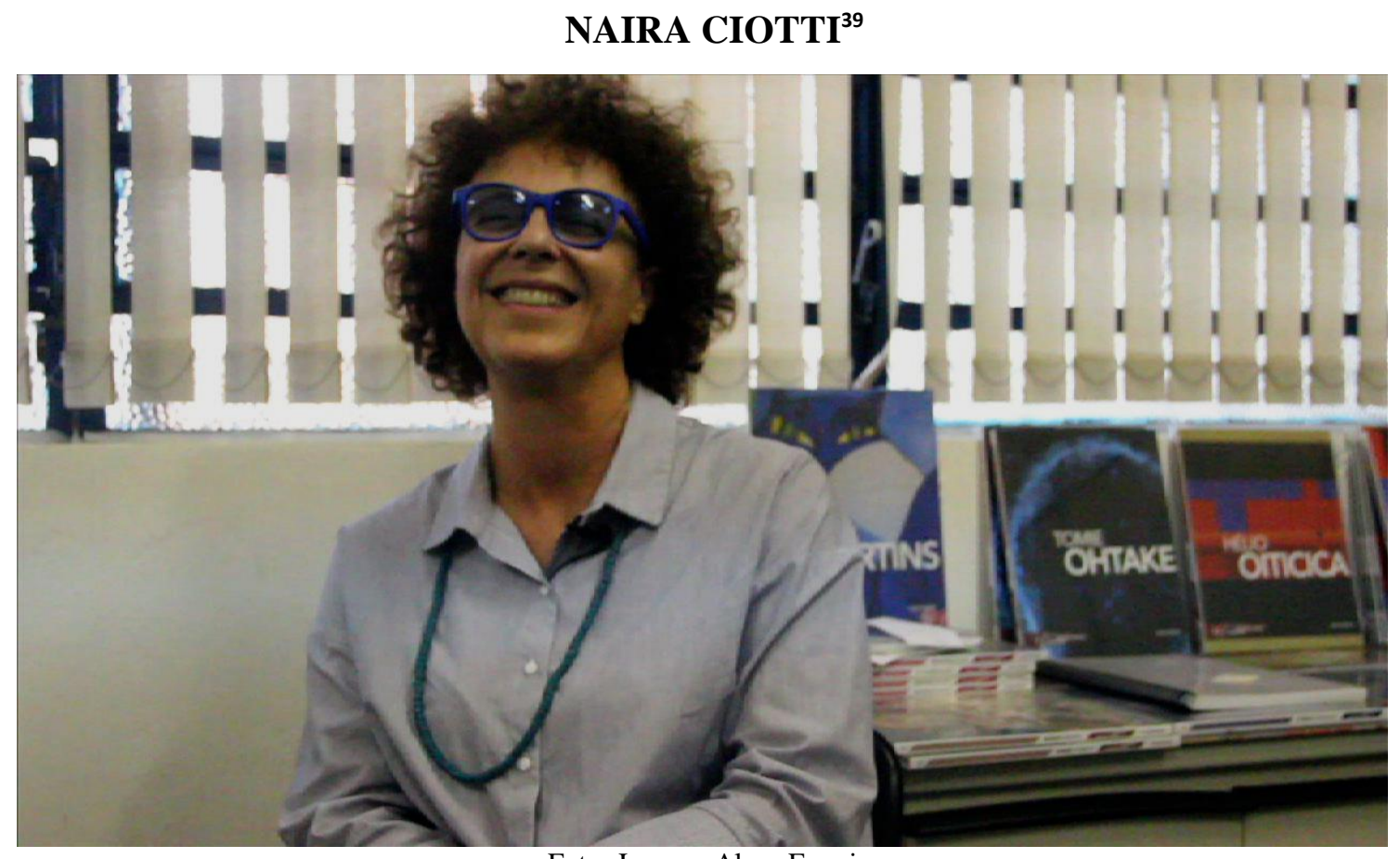

Foto: Joseane Alves Ferreira

É professora-performer, com bacharelado e licenciatura em História pela Universidade de São Paulo (1983). Mestrado concluído em 1999 com o título O híbrido professor-performer: uma prática, sob a orientação da Profa. Dra. Ana Cristina Pereira de Almeida. Doutora em Signo e Significação das Mídias no Programa de Pós-Graduação em Comunicação e Semiótica na Pontifícia Universidade Católica de São Paulo, sob orientação dos professores Renato Cohen e Christine Greiner sobre questões da performance arte, arte contemporânea na tecnocultura, a rede, a memória do corpo e os museus de arte: $O$ museu como mídia: performance e espaço colaborativo.

Atua desde 1994 como performer na cena artística. Entre seus trabalhos, os mais conhecidos foram: a performance Imanência, curadoria de Renato Cohen, uma permanência de oito dias, realizada por oito performers, na Casa das Rosas, São Paulo, 1997; Leitos Memória-tatuada, criação colaborativa com o poeta Erhi Araújo, no SESC Pompéia, em 2006; VOX2TEXT, no Sesc Pinheiros, em 2008, com a colaboração de Erhi Araújo, Otávio Donasci, Artur Matuck e Lúcio Agra.

Docente pesquisadora no Programa de Pós-Graduação em Artes Cênicas PPGArC, onde desenvolve diversas pesquisa ligadas a performance e teatro contemporâneo na Universidade Federal do Rio Grande do Norte. Publicou seu primeiro livro, intitulado O professor-performer. Concluiu, em 2014, estágio pós-doutorado no MAC/USP, Programa Interunidades em Estética e História da Arte - edital PNPD CAPES 2014, intitulado Musealização da Performance: Cartas a Renato Cohen, tendo como resultado a performance Cartas a Renato Cohen: teorias do esquecimento.

\footnotetext{
${ }^{39}$ Currículo enviado pela entrevistada.
} 


\section{APÊNDICE B - \\ ROTEIRO DAS ENTREVISTAS}

1 - O que é performance? É um desdobramento das artes cênicas? Ou é uma linguagem híbrida? [EXPLORAR: muitas performances fazem uso de vídeos, gravuras, imagens, objetos, enfim...]

2 - Como percebe o fato de um museu, galeria ou instituição ter em seu acervo performances?

3 - Na sua opinião, como deve ser construído um acervo de performance? Como é a descrição técnica/catalogação desta linguagem? [EXPLORAR: alguns artistas registram seus trabalhos por meio de fotos e vídeos, mas existem aqueles que não permitem nenhum registro, como poderia resolver este paradigma?]

4 - Sabemos que alguns artistas usam seus corpos nas performances, mas há aqueles que criam seus trabalhos para outros realizarem. Como percebe a performance como arte moderna e contemporânea? [EXPLORAR: arte é a criação e não execução?] Como isto se dá em um museu? Como o público responde?

5 - Como acontece o mercado de performance, já que não é um bem material? Sabe-se que obras caracterizadas pela materialidade como pintura, escultura, e tridimensionais são produtos comercializados em feiras, leilões e são objetos pertencentes as instituições e coleções de arte. Como acontece com a performance? A reprodução das performances em foto e vídeo seria o produto comercializado?

6 - Como registrar, divulgar e perpetuar o trabalho de um artista com as características da performance? A fotografia e o vídeo são meios de eternizar estas ações, essas experiências? Como as pessoas que não puderam estar presentes a estas vivências poderiam conhecer, pesquisar esses trabalhos?

7 - Há mais alguma consideração sobre performance que queira falar? Deixei de perguntar algo relevante, que você gostaria de abordar? Ou desejaria falar mais alguma coisa? 


\section{ANEXOS}


ANEXO I -

PERFORMANCE “O NOME”, DE MAURÍCIO IANÊS, PROJETO OCTÓGONO, PINACOTECA DO ESTADO, SÃO PAULO (2013)

Simba

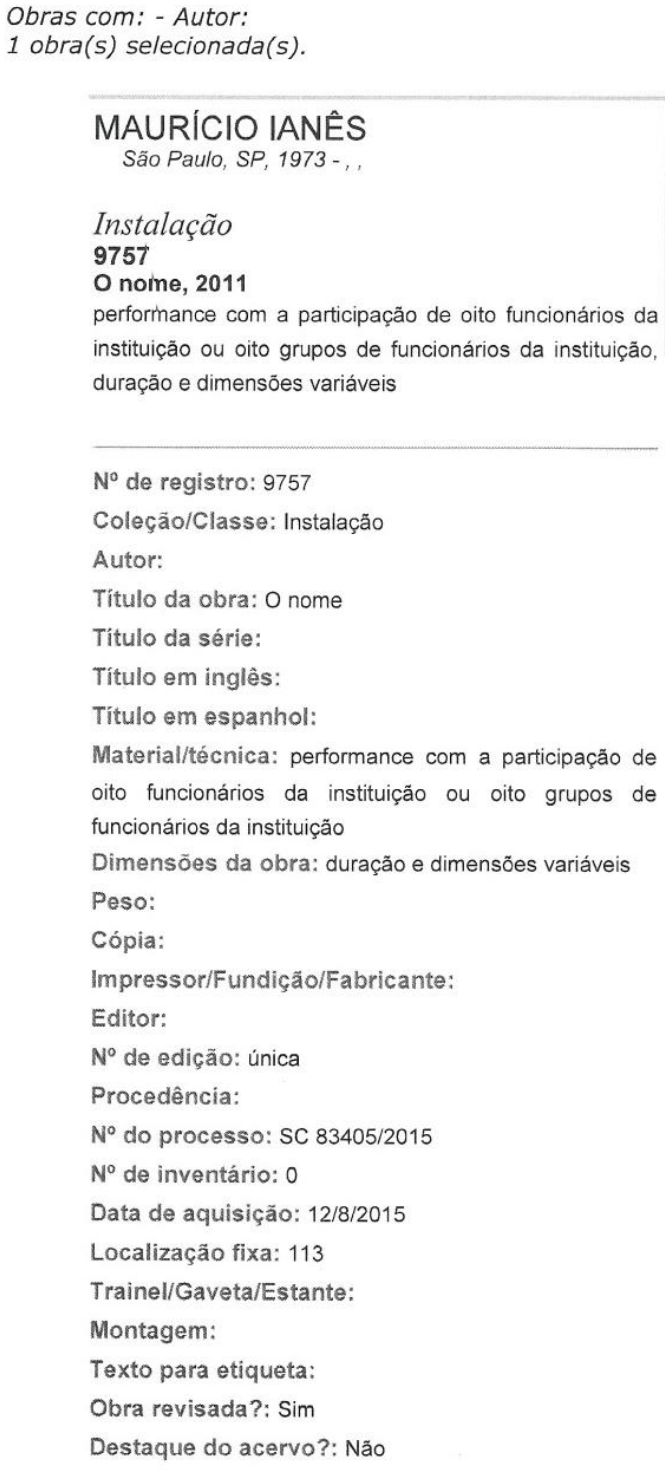

[Controle: 01/02 - Nome do objeto: O nome (dossiê)] Assinada: Não - Transcrição da assinatura: - Onde: Marcada: Não - Onde: 
Datada: Sim - Onde: - Data:

Data atribuída: 2011

Localizada: Não - Onde:

Outras inscriçöes: Na PEÇA:

- "Informações catalográficas: // Cod.: 13590131 /I

Título: O nome // Ano: 2010/2011 // Artista: Maurício

lanês /" Técnica: Performance /" Duração:

variáveis" (no suporte, ce, impressão digital)

Material / técnica: 14 páginas em impressão digital

sobre papel

Descrição formal:

Localização atual:

Estado de conservação:

Fotografia: Não - Negativo: Não - Diapositivo: Não -

Restaurada: Não

- Dimensões -

Parte:

$29,80 \times 21,10 \mathrm{~cm}$ - Peso: - Formato:

Moldura: Não

Base: Não

Passe partout: Não

[Controle: 02/02 - Nome do objeto: O nome (pendrive)]

Assinada: Não - Transcrição da assinatura: - Onde:

Marcada: Não - Onde:

Datada: Não - Onde: - Data:

Data atribuída: 2011

Localizada: Não - Onde:

Outras inscrições: No PENDRIVE:

Pasta:

Maurício lanês - O nome (2010-2011)

- Mauricio lanês_O NOME (2010-2011) Dossiê

16/03/2015 15:17 Adobe Acrobat Document 257 KB

- Sem título - 1 cópia 16/03/2015 15:22 Imagem JPG

$1.628 \mathrm{~KB}$

- Sem título - 2 cópia 16/03/2015 15:22 Imagem JPG

$1.616 \mathrm{~KB}$

- Sem título - 3 cópia 16/03/2015 15:22 Imagem JPG

$1.616 \mathrm{~KB}$

Material / técnica: pendrive

Descrição formal:

Localização atual:

Estado de conservação:

Fotografia: Não - Negativo: Não - Diapositivo: Não -

Restaurada: Não

- Dimensões - 
Parte:

$5,20 \times 2,00 \mathrm{~cm}$ - Peso: - Formato:

Moldura: Não

Base: Não

Passe partout: Não

PESQUISA:

-Data de aquisição: será a da publicação no D.O.E. A obra foi aprovada polo COA em 28 de novembro de 2014. A obra foi entregue à instituição em 18 de março de 2015. O processo de doação foi aberto em 18 de junho de 2015.

- Forma de aquisição: obra adquirida com fundos levantados pelo programa "Patronos da Arte Contemporânea da Pinacoteca do Estado de São Paulo", edição de 2014, para ser doada ao acervo da instituição. - Data: embora os documentos entregues junto à obra apresentem como data o par 2010/2011, o autor confirmou em entrevista para o INCCA (International Network for the Conservation of Contemporary Art), realizada na Pinacoteca do Estado, em 12/05/2015, e localizada junto ao Núcleo de Conservação e Restauro da instituição, que a obra presente no acervo é do ano de 2011. A datação anterior, compreendendo os dois anos estava relacionada a uma versão desta obra, apresentada na "Verbo - Mostra de Performance Art" (6 Ed.), na Galeria Vermelho, São Paulo, SP, em 2010. Optamos, desta forma, e com a ciência do autor, atribuir o ano de 2011 para a performance presente no acervo. - No de edição: conforme a já citada entrevista para o INCCA, de 12/05/2015, o autor afirmou tratar-se de uma obra única.

- Montagem: para a realização da performance, além de instruções preliminares localizadas no descritivo entregue pelo autor, localizado na Reserva Técnica da instituiçăo, há mais informações na já referida entrevista do INCCA. O autor assinala que para a performance acontecer é necessário que haja oito funcionários, ou múltiplos de 8 , ou oito grupos de funcionários da instituição para cada letra da palavra INEFÁVEL. Sobre a escolha destes funcionários, o ideal é que participem funcionários de diversas equipes do museu, terceirizados, temporários, entre outros. Em caso de formação de grupos, não é possivel que um grupo possua mais ou menos integrantes do que os outros, 
pois não é esperado que uma das letras seja proeminente em relação às demais. Uma vez tendo constituido o grupo de funcionários, é necessário que os mesmos frequentem um workshop com o autor em que serão abordados exercícios de respiração, entrosamento da equipe, explicação do conceito da performance, entre outros. É importante frisar que somente funcionários que passarem por este workshop estão aptos a realizar a performance. Por isso, o autor recomenda que um número maior de funcionários participe do workshop, mesmo que não vá realizar a performance, pois no caso de ausência de um funcionário ativo na ação, outro poderá substituí-lo. Não é permitido realizar a performance caso um dos integrantes falte e não tenha um substituto apto, observando as regras dispostas acima.

Inicialmente pensado para ser um site specific para o espaço Octógono da Pinacoteca, o trabalho possui regras para ser apresentado neste local. Os individuos ou grupos responsáveis pelas letras devem se apresentar na ordem em que as mesmas aparecem na palavra. A letra inicial "I" pode ocupar o nicho localizado do lado aposto à entrada principal do Octógono, e os demais grupos devem se posicionar no sentido de ordem da palavra, em sentido horário. Se a performance for apresentada em outro espaço do museu, os funcionários ou grupos podem se misturar no espaço. É possivel, inclusive, que a performance ocorra em um espaço junto a outras obras. O autor considera inviável mais de duas apresentações por dia e admite mudanças no projeto inicial do trabalho propostas pelos próprios funcionários envolvidos com a performance.

Para a performance, os funcionários ou grupos de funcionários devem sair de seus postos de trabalho nos horários combinados para a ação, usando as roupas do cotidianos ou seus uniformes, se deslocando calmamente e, de forma discreta, adentrando o espaço da ação posicionando-se nos nichos destinados à cada letra da palavra INEFÁVEL. Uma vez todos em seus lugares, nenhum anúncio é feito, e os participantes deverão tomar fôlego e cantar de uma só vez a letra correspondente da palavra, juntos. Terminado o fôlego $e$ o som de sua letra, os participantes podem deixar o local de forma discreta e independente, ou seja, não é necessário esperar todos terminem de cantar suas letras. Sabendo da possibilidade de sua ausência em algum momento para ministrar o workshop, o autor está preparando um vídeo/workshop que deverá ser entregue à instituição em julho. Para maiores informações, incluindo informações de empréstimo da obra, ver INCCA de $12 / 05 / 2015$. 


\begin{abstract}
- Partes: outros arquivos também estäo presentes no pendrive, parte $2 / 2$, mas se referem a informações que não fazem parte da obra. Optamos por descrevê-los sucintamente, portanto, em Pesquisa. São eles CV do autor, clipping do autor, textos e portfólio, todos inseridos na Pasta "Maurício lanês (dossier)".

- Exposição: uma versão da presente obra foi apresentada na "Verbo - Mostra de Performances Arte" em sua $6^{a}$ edição, na Galeria Vermelho, São Paulo, SP, em 2010.

- Informações complementares: esta é a primeira obra da categoria performance a integrar o acervo da Pinacoteca do Estado.

Em entrevista ao INCCA, de 12/05/2015, o autor enfatizou a necessidade de ser realizados registros da performance, a cada vez que a mesma for apresentada, através de fotos/listas de participantes. Este material pode ser apresentado em exposiçōes contanto que seja evidenciado que se trata de um registro documental de performance, e não uma obra. Este tópico deve ser aprofundado entre a equipe técnica com vistas a designar, inclusive, um local de guarda desse arquivo.

\section{OBSERVAÇÕES:}

\title{
EXPOSIÇÕES:
}

- O nome, Pinacoteca do Estado de São Paulo, São Paulo, São Paulo, Brasil. de 28 de novembro a 30 de novembro de 2013. Projeto Octógono

- Verbo, Galeria Vermelho, Săo Paulo, São Paulo, Brasil. de 26 de julho a 31 de julho de 2010.

\section{REFERÊNCIAS BIBLIOGRÁFICAS:}

Fonte: Documento cedido por Fernanda D'Agostino, coordenadora do Núcleo do Acervo Museológico, responsável pela catalogação da Pinacoteca de São Paulo 


\section{ANEXO II - \\ DESCRIÇÃO PERFORMANCE "PARANGOLÉ”, DE LOURIVAL CUQUINHA}

(diálogo via e-mail descrevendo a ação)

Pensei que a performance Parangolé ser pode adquirida da seguinte maneira:

1. Via algumas maneiras de termos a Farda (comprar ou fazer igual). Na SP Arte e em outras ocasiões que trabalhei com a farda da polícia (Brasil, Alemanha, Portugal) aluguei ou consegui emprestada. Como a Farda da PM de Sampa muda de tempos em tempos pode-se aluga-la quando se for fazer a performance. O aluguel sai mais ou menos por $\mathrm{R} \$ 250$ a semana num fornecedor que posso passar o contato e sempre para filmes e arte em geral. Se a obra for feita em outro lugar terá que ser feita com a farda do estado ou país no qual ela for apresentada.

2. Conseguirei os acessórios (cacetete e arma) que devem ser entregues ao museu e ficar como parte da indumentária da performance. Podemos conversar pessoalmente sobre eles.

abs e inté já

- título da obra: Parangolé

- algumas performances que possuem a contratação de um performer geralmente ocorrem no dia de abertura de exposição ou são exibidas ao longo de toda o período expositivo. Há alguma restrição sobre isso ou Pode ser uma decisão do curador sobre o tempo de ocorrência da performance?

\section{Idealmente:}

1. Contratamos uma ator (idealmente Lui Wagner:

https://www.facebook.com/lui.duol?fref=ts) e ele deve ficar pela exposição como que fazendo a segurança, olhando intimidadoramente as pessoas (como de praxe faz a polícia nas ruas conosco que andamos de bike, a pé ou de transporte público). 2. Não temos identificação da obra perto dela.

3. Ele dura toda a exposição, mas (não idealmente) podemos conversar sobre possíveis variações que resultarão em dias com a exposição só da farda na parede (foto anexa mostrando a disposição).

- como pensa o perfil físico do performer? Alguma orientação/ restrição como alto, baixo, mais forte, mais delgado, etc?

1. Lui Wagner: https://www.facebook.com/lui.duol?fref=ts

- qual a postura que o performer deve assumir durante a performance: não se comunica com o público? Feição mais fechada, brava, etc...

1. ele deve ficar pela exposição como que fazendo a segurança, olhando intimidadoramente as pessoas (como de praxe faz a polícia nas ruas conosco que andamos de bike, a pé ou de transporte público). Caso não seja Lui, tenho que ter um encontro com $o$ ator antes para dirigi-lo. 
- qual o espaço físico que o performer ocupa: ele fica em pé parado? Ele pode sentar ou circular pela exposição?

1. Podemos ter intervalos nos períodos da performance, mas ele deve circular pela exposição como que fazendo a segurança, olhando intimidadoramente as pessoas (como de praxe faz a polícia nas ruas conosco que andamos de bike, a pé ou de transporte público). Ele não senta. Caso não seja Lui, tenho que ter um encontro com o ator antes para dirigi-lo.

- quando pensa na locação da farda do policial, a farda deve ser da região onde a obra está sendo exposta? Pensa em alguma farda da polícia específica, como policial federal, civil? Por ex, a farda do Rio de Janeiro é diferente da farda de São Paulo. Como você pensa se a performance ocorrer em outro país: a farda deve ser do país a ser exposta?

1. Farda da PM no caso do Brasil, pois é a polícia das ruas.

2. A farda tem que ser a mesma usada nas ruas da região, estado ou país em que a exposição estiver acontecendo.

- qual é a lista de componentes da performance? Farda, cassetete, cinturão, colete, etc...

1. A farda (mesma usada nas ruas da região, estado ou país em que a exposição estiver acontecendo)

2. Cassetete, cinturão, colete e arma (no caso do Brasil, em outros lugares as mesmos instrumentos usados pela policia lá)

(tenho já alguns destes componentes)

- você tem o contato do local onde a farda foi alugada para a SP Arte?

Aluguel de Fardas:

http://www.v-unit.com.br/

Rua Rodésia 74/76 - Vila Madalena, SP.

Tel (11) 3031-4999

Cel (11) 982891386

inté já

Super obrigada,

Ciça 


\section{ANEXO III - \\ RECRUTAMENTO DE ARTISTA PARA EXECUTAR OBRA DE LAURA LIMA}

O Instituto Inhotim procura 4 homens para realizar Marra de Laura Lima

$\mathrm{Na}$ escultura viva da artista mineira Laura Lima, Marra, "dois homens nus empurram-se pelas mãos. Os rostos são velados por um capuz que lhes cobre a cabeça e os conecta, tornando-os inseparáveis.” (Através: Inhotim, p. 250) Não há vencedor. Apenas a pulsação e variação do ritmo da ação, ora mais intenso, ora menos. A obra levanta questões sobre a singularidade e a indiferenciação do corpo humano, e provoca um acontecimento de dependência e exaustão.

Procuramos jovens do sexo masculino, maiores de idade, que estejam dispostos a participar da ação e que não tenham problema em ficar sem roupa em público. Os participantes deverão ter disponibilidade para passar o dia no Instituto Inhotim.

Experiência prévia com ações desta natureza não é necessária, mas como o esforço físico faz parte da ação, os candidatos não poderão ter qualquer restrição neste sentido.

Dia: 8 de Setembro

Início Marra: $13 \mathrm{~h}$

Fim Marra: $17 \mathrm{~h}$

A obra acontece em sistema de revezamento e cada disputa tem a duração correspondente à resistência física da dupla.

Local: área externa da Galeria Mata/ Instituto Inhotim, Brumadinho.

É indicação da artista que as duplas de participantes não se conheçam entre si, pelo que aceitamos somente inscrições individuais.

O Instituto Inhotim fornecerá:

Transporte, alimentação,per dia de $\mathrm{R} \$ 250,00$ (pago em até 20 dias após a ação) e um livro Através: Inhotim para cada participante.

Para se inscrever:

Enviar um e-mail para maria.eugenia@inhotim.org.br até as 20h do dia 14 de agosto, 2016. Por favor, colocar no assunto do e-mail: CANDIDATO MARRA e no corpo do email responder as seguintes perguntas:

Qual é o seu nome completo, data de nascimento, RG, endereço completo, Universidade onde estudou/ano de formatura, idade, altura, peso (aproximado)? Você tem alguma restrição médica que te impede de fazer esforço físico? Você tem algum problema em ficar nu ao ar livre e na presença de outras pessoas? Você tem disponibilidade de passar o dia no Instituto Inhotim no dia 08 de setembro, 2016 ?

Anexar ao e-mail uma foto de corpo completo com vestimentas normais. Não é necessário o envio de foto nu. (INHOTIM, S.d.) 


\section{ANEXO IV - \\ COLEÇÃO MAC-USP - REGISTROS DE AÇÃO, DE PERFORMANCE E DE INSTALAÇÃO}

\section{COLEÇÃO MAC USP - registros de ação, de performance e de instalação}

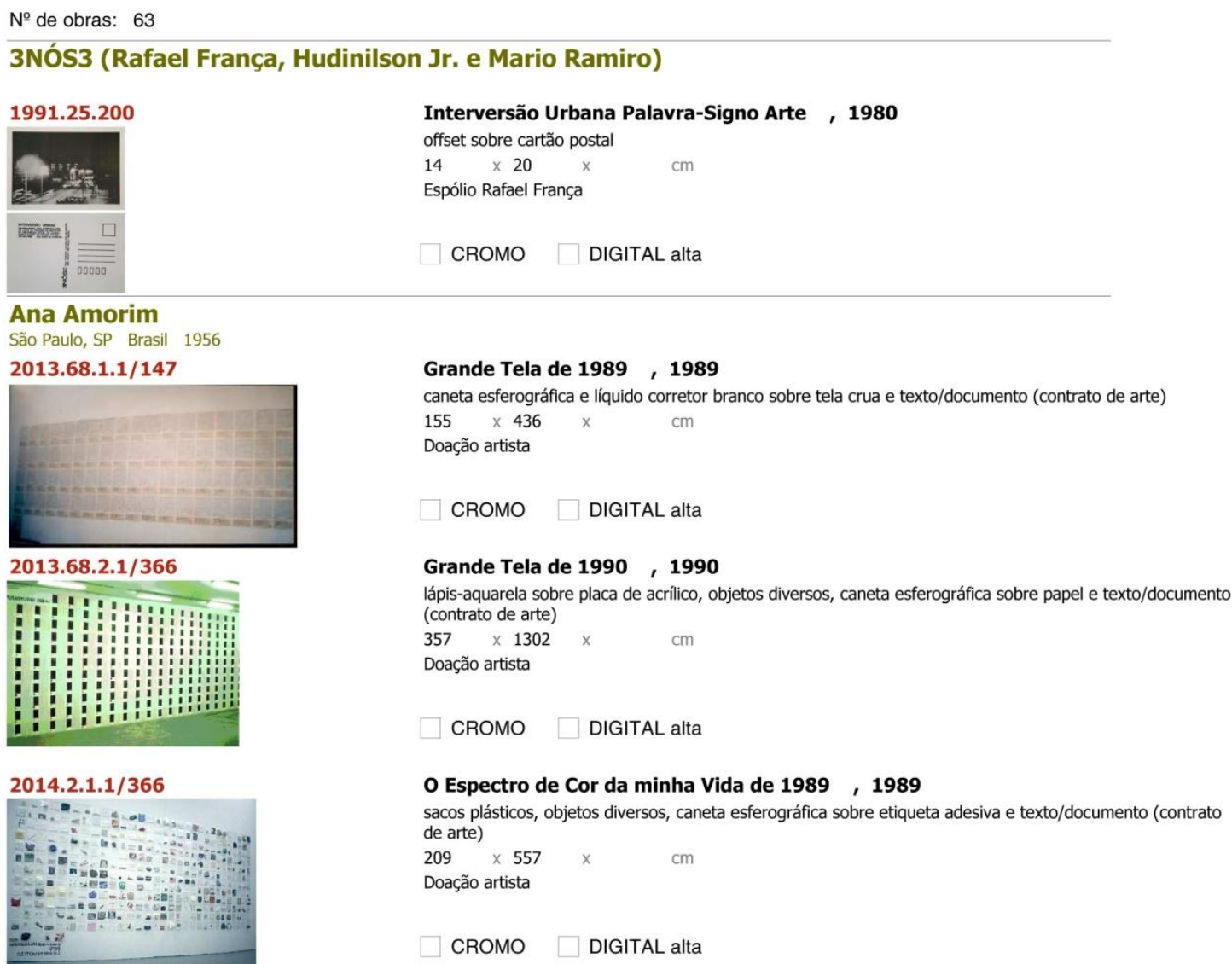

2014.2.1.1/366

O Espectro de Cor da minha Vida de 1989 ，1989

sacos plásticos, objetos diversos, caneta esferográfica sobre etiqueta adesiva e texto/documento (contrato de arte)

$209 \times 557 \times \mathrm{cm}$

Doação artista

CROMO $\square$ DIGITAL alta

Nelson Pinheiro de Andrade e Diego Miguel Buser

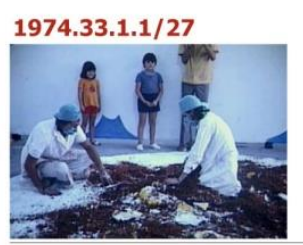

Artur Barrio

Porto Portugal 1945

1970.19.1.1/3

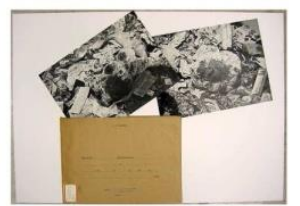

1973.18.1.1/9

BARRÍO

SITT.... CIDADE...

-....... CAMPO-

RIO DEJANERO 1970

1973.18.2.1/27

25/09/2017

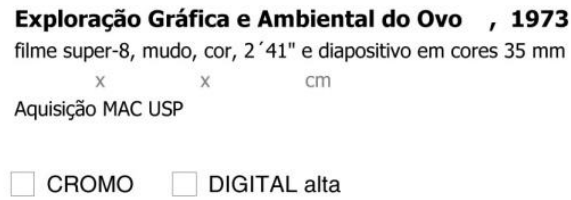

CROMO DIGITAL alta

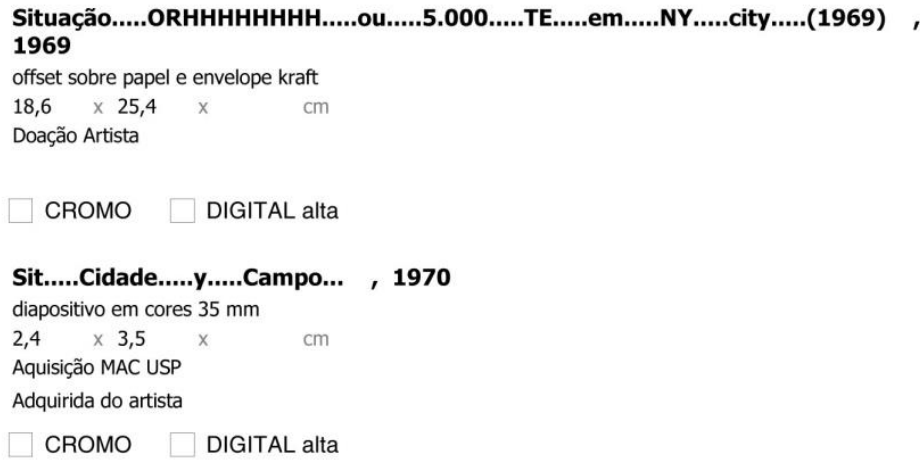




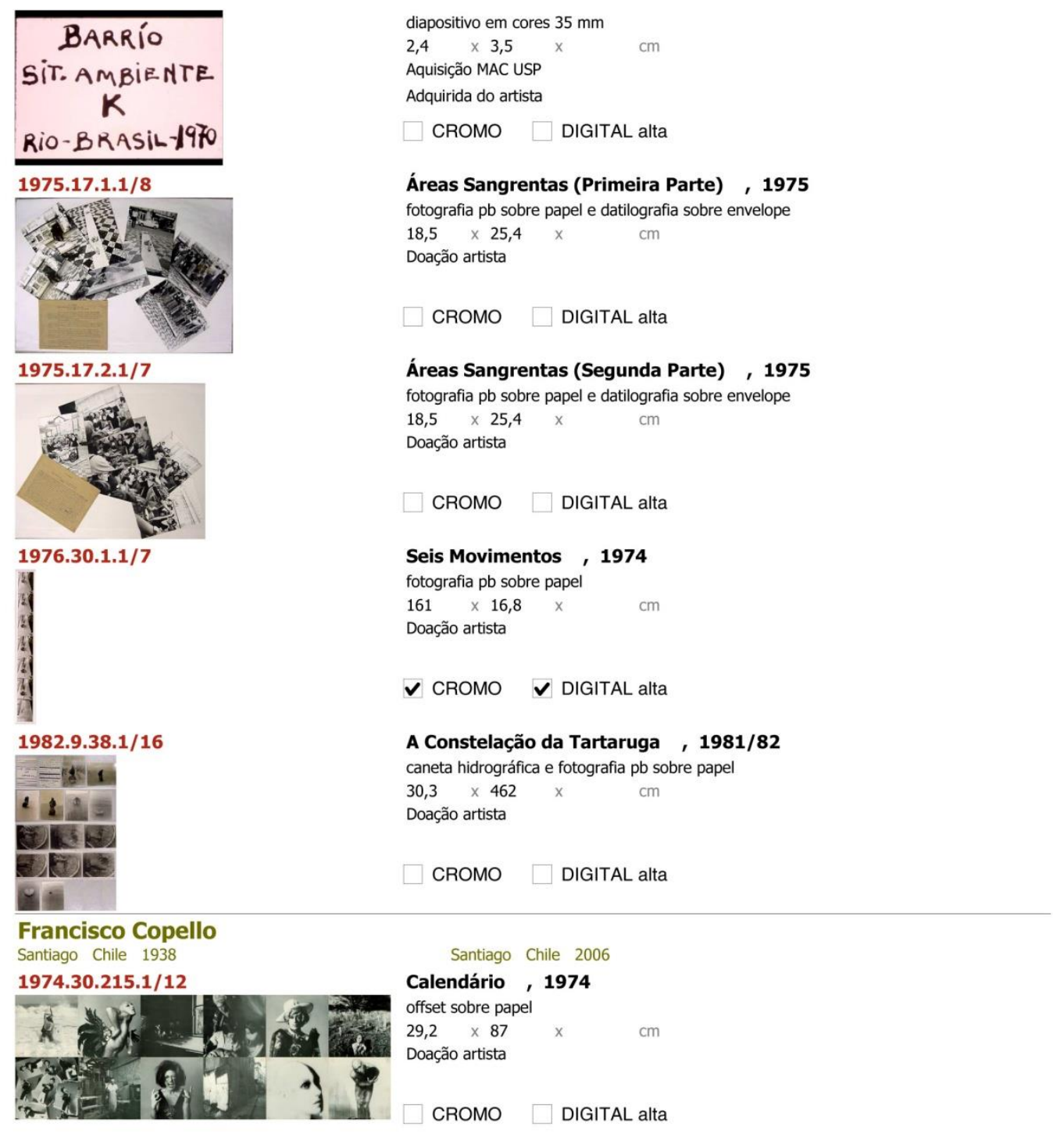

\section{Hervé Fischer \\ Paris França 1941 \\ 1975.26.7.1/21}

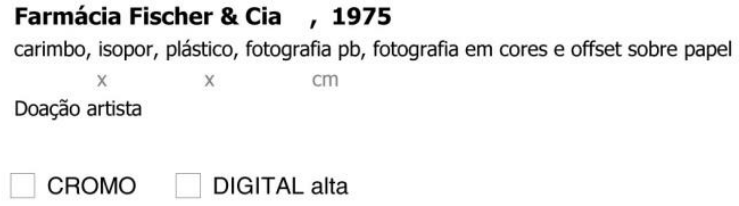

2014.27.1

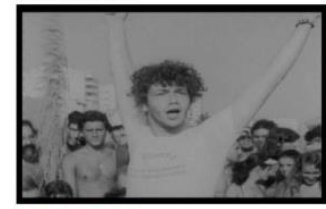

2014.27.2
Performance Interversão Movimento de Arte Pornô, 1982 vídeo digital VOB, som, $\mathrm{pb}, 04^{\prime} 41^{\prime \prime}$

$\underset{x}{x} \times{ }^{2}$
Doação artista
$\square$ CROMO $\square$ DIGITAL alta

Performance Interversão Movimento de Arte Pornô, 1982 


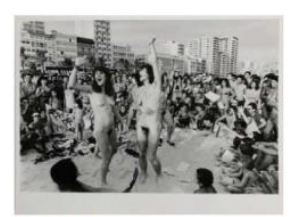

2014.27.3

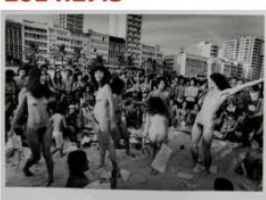

2014.27.4

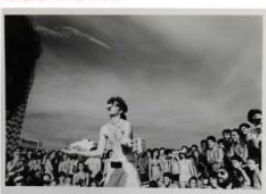

fotografia em gelatina e prata sobre pape

$17,9 \times 23,9 \times \mathrm{cm}$

Doação artista

CROMO DIGITAL alta

Performance Interversão Movimento de Arte Pornô, 1982

fotografia em gelatina e prata sobre papel

$18 \times 23,9 \times \mathrm{cm}$

Doação artista

CROMO $\square$ DIGITAL alta

Performance Interversão Movimento de Arte Pornô, 1982 fotografia em gelatina e prata sobre papel

$18 \times 23,9 \times \mathrm{cm}$

Doação artista

CROMO $\square$ DIGITAL alta
Isidoro Valcárcel Medina

Murcia Espanha 1937

1976.40.1.1/12

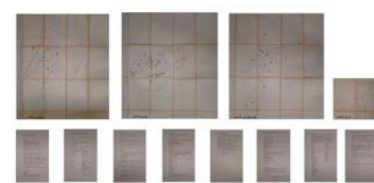

$1976.40 .2 .1 / 367$

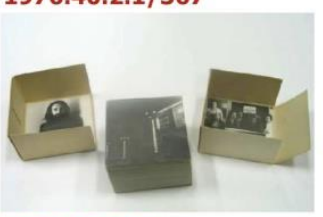

1977.18 .238

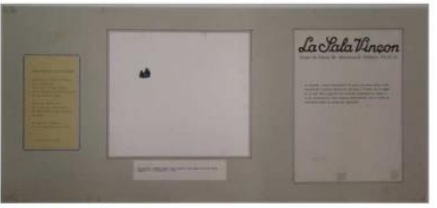

1977.18 .239 .1

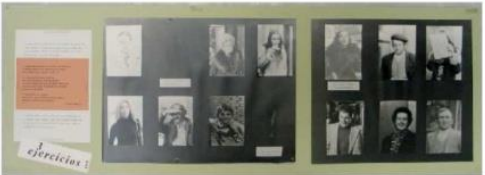

1977.18.239.2

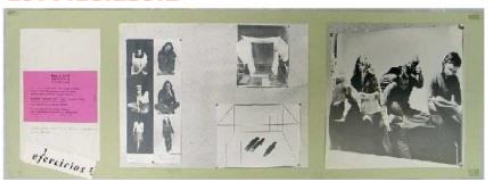

1977.18.239.3

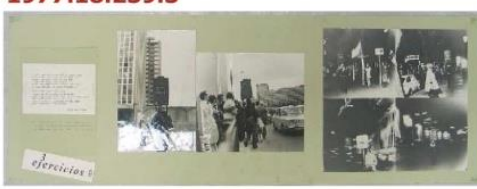

12 Exercícios de Medição sobre a Cidade de Córdoba ， 1974

fotocópia e heliografia sobre papel

$130 \times 340 \times \mathrm{cm}$

Doação artista

CROMO DIGITAL alta

Relógios , 1973

offset sobre papel e caixa de papel cartão

$9,8 \times 9,8 \times 5,8 \mathrm{~cm}$

Doação artista

CROMO $\square$ DIGITAL alta

\section{Definição do Lugar Habitual ， 1975}

datilografia, fotografia pb e offset sobre papel colados sobre hidrográfica sobre pape

$38,1 \times 82,4 \times \mathrm{cm}$

Doação artista

CROMO $\square$ DIGITAL alta

\section{Retratos de Rua 3 Ejercicios, 1975}

datilografia, fotografia pb, caneta hidrográfica e tipografia sobre papel colados sobre papel $35,3 \times 100,2 \times \mathrm{cm}$

Doação artista

CROMO DIGITAL alta

\section{Retratos de Estúdio 3 Ejercicios, 1976}

datilografia, fotografia pb, caneta hidrográfica e tipografia sobre papel colados sobre papel

$35,3 \times 100,2 \times \mathrm{cm}$

Doação artista

CROMO $\square$ DIGITAL alta

\section{Homens Anúncio 3 Ejercicios, 1976}

datilografia, fotografia pb, caneta hidrográfica e tipografia sobre papel colados sobre papel $35,3 \times 100,2 \times \mathrm{cm}$

Doação artista

CROMO $\square$ DIGITAL alta 


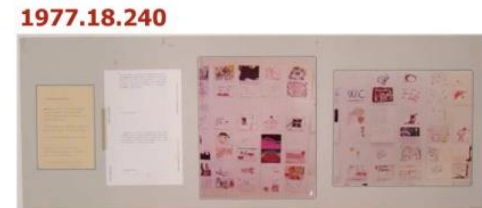

1977.18.316.1/16
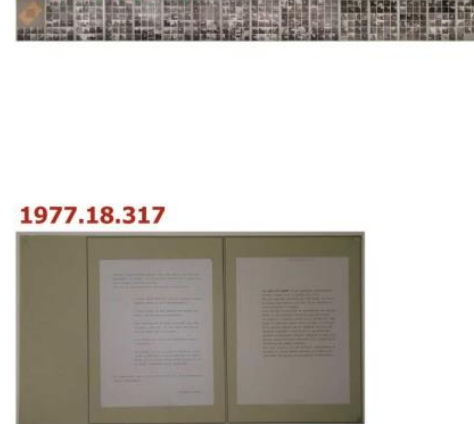

1977.18.318

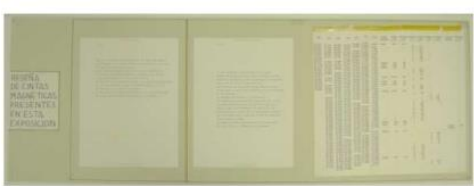

1977.18.324.1/7

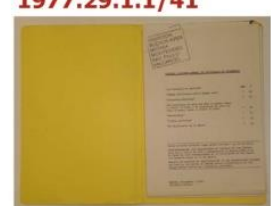

Marta Minujín

Buenos Aires Argentina 1943

1977.18.167.1/23

Cartões Ilustrados ， 1975

datilografia, fotografia em cores e tipografia sobre papel e fita adesiva colados sobre hirográfica sobre papel $35,4 \times 100,7 \times$

Doação artista

CROMO $\square$ DIGITAL alta

Relógios , 1973

heliografia e offset sobre papel colados sobre papel

$64 \times 704 \times \mathrm{cm}$

Doação artista

CROMO DIGITAL alta

\section{Sem título e O Sena por Paris , 1975}

datilografia e fotocópia sobre papel colados sobre hidrográfica sobre papel

$35,2 \times 63,3$

$\mathrm{cm}$

Doação artista

CROMO $\square$ DIGITAL alta

Resenha das Fitas Magnéticas Presentes nesta Exposição: Conversas Telefônicas e Motores , 1973

datilografia e caneta hidrográfica sobre papel e fita adesiva colados sobre papel

$35,2 \times 100,2 \times \mathrm{cm}$

Doação artista

CROMO $\square$ DIGITAL alta

12 Exercícios de Medição sobre a Cidade de Córdoba ， 1974

fotocópia e caneta hidrográfica sobre papel colados sobre papel e heliografia sobre papel

$101,8 \times 507 \times \mathrm{cm}$

Doação artista

CROMO DIGITAL alta

Informe e Resumo Geral de Atividades na América do Sul ， 1976

carimbo e fotocópia sobre papel

$31,5 \times 21,5 \times \mathrm{cm}$

Doação artista

CROMO DIGITAL alta

Repolhos Arte Agrícola em Ação, 1977

fotografia pb sobre papel

$76 \times 216 \times c m$

Doação artista

CROMO $\square$ DIGITAL alta

\section{Antoni Miralda}

Barcelona Espanha 1942

1998.3

Sem título , década1970
fotografia em cores sobre papel
$\begin{aligned} & 24,6 \times 17 \times \\ & \text { Doação artista }\end{aligned}$
$\checkmark$ CROMO $\quad$ DIGITAL alta


Patricia Osses

Santiago Chile 1971

2011.8.1

2011.8.2

2011.8.3

2011.8.4

2011.8.5

impressão em cores sobre papel
$80 \times 51 \times \mathrm{cm}$
Doação Shopping Iguatemi São Paulo
Adquirida na SPArte 2011 para doação ao MAC USP
$\square$ CROMO $\square$ DIGITAL alta

Jean Otth

Lausanne Suiça 1940

1973.17.1.1

1973.17.1.2

1973.17.1.3

1973.17.1.4
Fachada $1,2009 / 10$

impressão em cores sobre papel

$80 \times 51 \quad \times \quad \mathrm{cm}$

Doação Shopping Iguatemi São Paulo

Adquirida na SPArte 2011 para doação ao MAC USP

CROMO $\square$ DIGITAL alta

Fachada 2 , 2009/10

impressão em cores sobre papel

$51 \times 80 \times \mathrm{cm}$

Doação Shopping Iguatemi São Paulo

Adquirida na SPArte 2011 para doação ao MAC USP

CROMO DIGITAL alta

Fachada 3 Casapina, 2009/10

impressão em cores sobre papel

$80 \times 51 \quad \times \quad \mathrm{cm}$

Doação Shopping Iguatemi São Paulo

Adquirida na SPArte 2011 para doação ao MAC USP

CROMO DIGITAL alta

impressão em cores sobre papel

$80 \times 51 \times \mathrm{cm}$

Doação Shopping Iguatemi São Paulo

Adquirida na SPArte 2011 para doação ao MAC USP

CROMO DIGITAL alta

Fachada 5 Casapina, 2009/10

mpressão em cores sobre papel

CROMO $\square$ DIGITAL alta

\section{Limite Video Tape, 1973}

fotografia pb sobre papel

$74,7 \times 100 \times \mathrm{cm}$

Doação artista

CROMO DIGITAL alta

Limite Video Tape, 1973

fotografia pb sobre papel

$74,7 \times 100 \times \mathrm{cm}$

Doação artista

$\checkmark$ CROMO $\square$ DIGITAL alta

Limite Video Tape, 1973

fotografia pb sobre papel

$74,7 \times 100 \times \mathrm{cm}$

Doação artista

$\checkmark$ CROMO $\square$ DIGITAL alta

Limite Video Tape, 1973
Fachada 4 Casapina, 2009/10 
fotografia pb sobre papel

$74,7 \times 100$

Doação artista

$\checkmark$ CROMO $\square$ DIGITAL alta

1973.17.1.5

Limite A Video Tape, 1973

fotografia pb sobre papel

$74,7 \times 100 \times \mathrm{cm}$

Doação artista

$\checkmark$ CROMO $\square$ DIGITAL alta

1973.17.1.6

Limite A Video Tape, 1973

fotografia pb sobre papel

$74,7 \times 100 \times \mathrm{cm}$

Doação artista

$\checkmark$ CROMO $\square$ DIGITAL alta

1973.17.1.7

Limite A Video Tape, 1973

fotografia pb sobre papel

$74,7 \times 100 \times$

Doação artista

$\checkmark$ CROMO DIGITAL alta

1973.17.1.8

Limite B Video Tape, 1973

fotografia pb sobre papel

$74,7 \times 100 \times x$

Doação artista

$\checkmark$ CROMO $\square$ DIGITAL alta

1973.17.1.9

Limite E Video Tape, 1973

fotografia pb sobre papel

$74,7 \times 100$

Doação artista

CROMO DIGITAL alta

1973.17.1.10

Limite E Video Tape, 1973

fotografia pb sobre papel

$74,71 \times 100 \times \mathrm{cm}$

Doação artista

$\checkmark$ CROMO $\square$ DIGITAL alta

Clemente Padín

Lascano, Rocha Uruguai 1939

1974.30.140.1/4

\author{
O Artista Está a Serviço da Comunidade ， 1974 \\ fotografia pb sobre papel \\ $16,4 \times 11$ \\ Doação artista \\ CROMO $\checkmark$ DIGITAL alta
}


Fernando Piola

São Paulo, SP Brasil 1982

2013.10.1.1/37

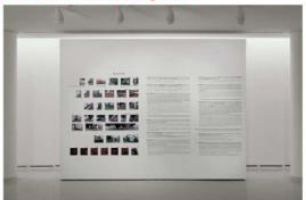

Regina Silveira

Porto Alegre, RS Brasil 1939

1994.10.8

\section{Operação Tutoia ，2007/12}

recorte em vinil adesivo e fotografia em cores sobre papel

$162 \times 350$

Doação artista

CROMO $\checkmark$ DIGITAL alta
Jogo do Segredo Jogos de Arte, 1977

offset sobre papel

$61,7 \times 48,4 \times \mathrm{cm}$

Doação artista

CROMO DIGITAL alta

\section{Regina Vater}

Rio de Janeiro, RJ Brasil 1943

1988.15.1

1988.15 .2

1988.15 .3

1988.15 .4

1988.15.5

1988.15 .6

1988.15.7

$25 / 09 / 2017$

\author{
Yauti Marandua ，1979/83 \\ fotografia pb sobre papel \\ $50 \times 49,9 \times \mathrm{cm}$ \\ Doação artista \\ CROMO $\square$ DIGITAL alta
}

Instalação em Preto para Tartarugas Prateadas I , 1984/85

fotografia pb sobre papel

$40,6 \times 50,6 \times \quad \mathrm{cm}$

Doação artista

CROMO $\square$ DIGITAL alta

Instalação em Preto para Tartarugas Prateadas II ，1984/85

fotografia pb sobre papel

$40,6 \times 50,6 \times$

Doação artista

CROMO DIGITAL alta

Com a Ajuda da Aranha , 1987

fotografia em cores sobre papel

$60,4 \times 45,7 \times$

Doação artista

CROMO $\square$ DIGITAL alta

\section{Flauta Tíbia I , 1988}

fotografia em cores sobre pape

$40,7 \times 50,6$

Doação artista

CROMO $\square$ DIGITAL alta

Flauta Tíbia III ， 1988

fotografia em cores sobre papel

$40,7 \times 50,6$

Doação artista

$\checkmark$ CROMO $\square$ DIGITAL alta

Flauta Tíbia III , 1988 

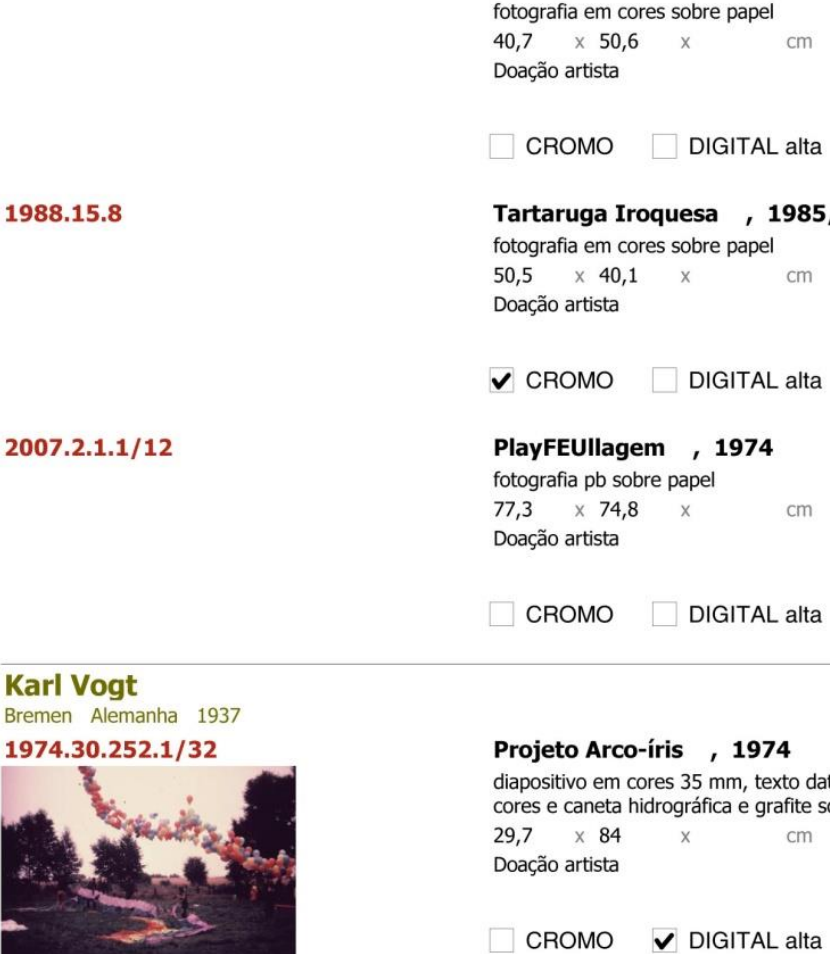

Projeto Arco-íris ， 1974

diapositivo em cores $35 \mathrm{~mm}$, texto datilografado, recortes de offset, lápis-de-cor sobre recorte de offset em cores e caneta hidrográfica e grafite sobre recortes de papel sobre cartão

$29,7 \times 84$

Doação artista

CROMO $\checkmark$ DIGITAL alta

Krysztof Wodiczko

Varsóvia Polônia 1943

1974.30.7.1/4

Veículo ， 1973

fotografia pb sobre papel

$25,6 \times 82 \times$

Doação artista

CROMO $\checkmark$ DIGITAL alta

\section{Carlos Zilio}

Rio de Janeiro, RJ Brasil 1944

1974.30.157

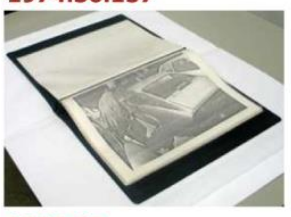

Documentação Fotográfica de um Objeto ， 1974

fotocópia sobre papel em pasta de plástico

$29,7 \times 24,4 \times 1,8 \mathrm{~cm}$

Doação artista

CROMO DIGITAL alta

1975.25

Para um Jovem de Brilhante Futuro , 1974

fotografia pb e offset sobre papel

$11,6 \times 18$

Doação artista

CROMO DIGITAL alta

Fonte: Documento cedido pelo Museu de Arte Contemporânea de São Paulo [MAC-USP] 